Historic, Archive Document

Do not assume content reflects current scientific knowledge, policies, or practices. 



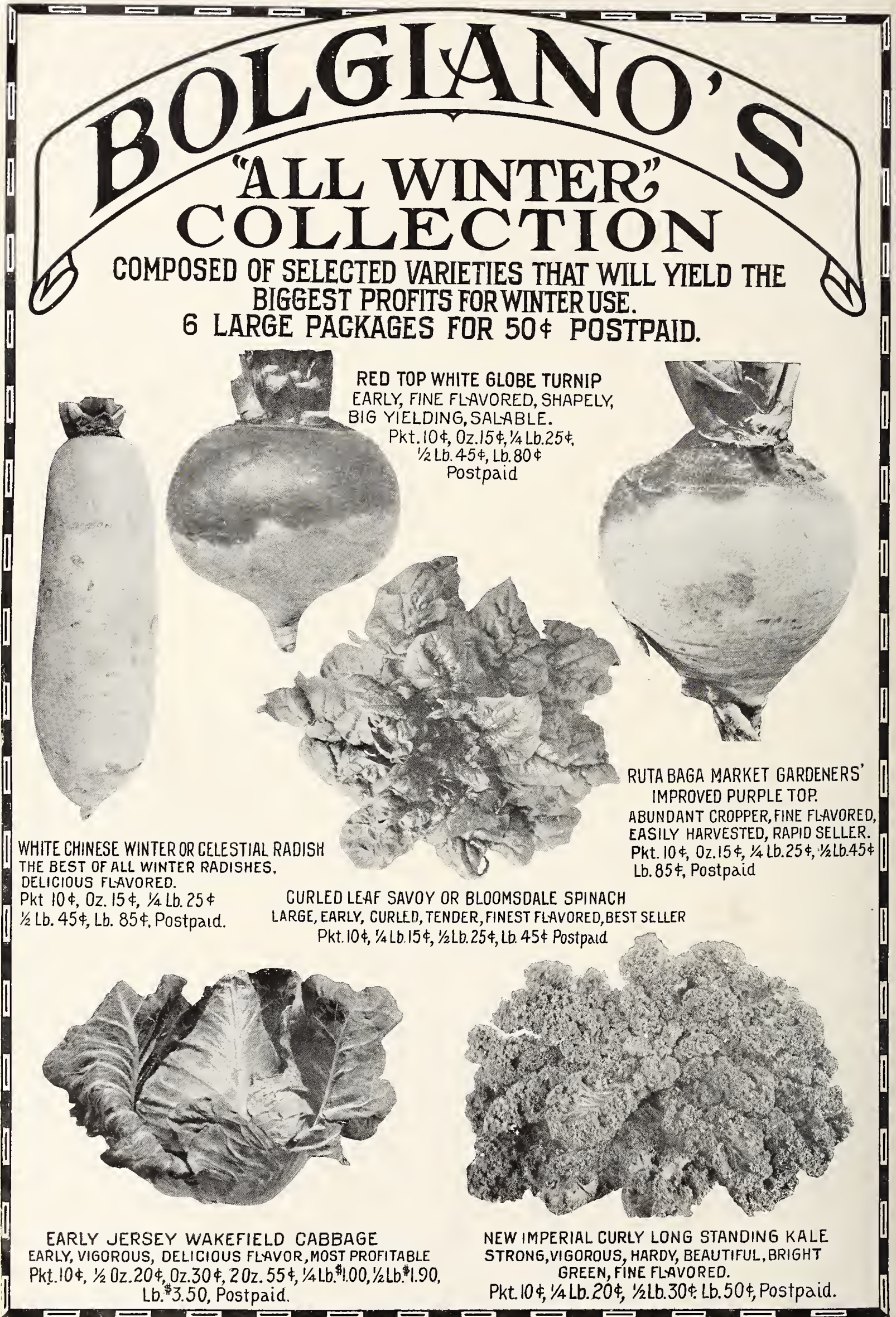




\section{REFERENCE TABLE}

Is paragus, 1 oz. to 200 lilants or 50 feet of

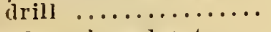
Barles, broadcast...... ts ibs. $2 \frac{1}{2}$ bu.

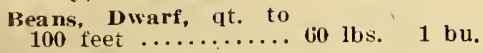
100 feet $\ldots \ldots \ldots \ldots \ldots$. 100 bills ........... 60 lbs. $1 / 2$ bu. Beets, Garden, 1 oz. to 6 lbs. Beet, Nangel, 1 oz. to 100 feet ............. Buckwheat, broadcast.
(abbage, 1 oz. to 4,000 () lants $\ldots$ arrot, 1 to $100 \mathrm{ft}$ Carrot, 1 oz. to 100 ft. Caulifiower, oz. 3,000 plauts …........ plants, 1 oz. to 100 (lover, Alsike \& White $60 \mathrm{ibs}{ }^{1 / 2} \mathrm{lb}$ lbs. Clover, Alfalfa or Incerne

clover, Crimson or Scarlet n............. Clover, Mammoth Red follards, 1 oz. to 5,000 Collards, 1 oz. to 5,000 Corn, Sweet, sold by
measured bushels, 1 pint to 100 hills...

Corn, Salad, $3 \mathrm{oz}$. to 100 feet $\ldots \ldots \ldots \ldots$.

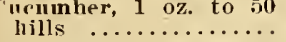
60 lbs. 20 lbs. 60 lbs. 15 lbs. $60 \mathrm{lbs} .12 \mathrm{lbs}$. ..... 1/4 lb. .... 6 qts. ..... 6 lbs. $60 \mathrm{lbs} .2 \mathrm{lbs}$.

No. Qutity
Lbs.
to Bu. Aer.

Egg Plant, 1 oz. to Grass, Kentucky Blue. 14 lbs. 28 lbs. Grass, Canadian Blue. $1+\mathrm{lbs} .30 \mathrm{lbs}$. Grass, Druid Hill Park Lawn Re. Top fancy recleaned $\ldots \ldots \ldots \ldots$......... Grass, Timotby

Grass, Orchard......... Italian lian,

Kale, 1 o\%. to 5,000 plants, 200 feet of Kohl Rabi, $1 \%$ oz. 100 feet

Lettuce, $1 / 4$ oz. to 10 io Lettuce, $1 / 4$ oz. to 100
feet of drill, 1 oz to feet of drill, $1 \mathrm{oz}$. to Melon, Musk, 1 oz. to 100 hills

Ielon, IV ater, $t \quad 0 \%$ to 100 hills

Okra, 1 oz. to 100 feet Oats, broadcast.

Onion Seed, $1 / 2$ oz. to 100 feet of drill....

Onion Sets, qt. to $40 \mathrm{ft}$. onion sets, qt. to $40 \mathrm{ft}$. Parsnip, $1 / 3$ oz. to 100 feet of drill... $\ldots \ldots$ to Parsley, $1 / 2$ oz. to 100
feet of drill ........
Peas, Garden, Smooth. Peas, Garden, Smooth.
30 lbs, 60 lbs

30 lbs. 10 lbs

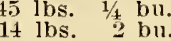

2 bul.

50 lbs. 5 lbs.

4 lbs.

3 lbs.

3 lbs.

5 lbs.

$\because$ ibs. $21 \%$ bus.

5 lbs.

60 lbs.

2 lbs. 8 bur.

5 lbs.

$3 \mathrm{lbs}$.

60 lbs. 1 bu.
Peas, Garden, Wrinkled,
1 pint to 100 teet of 1 pint to 100 teet of Peas, sugar Marrowfats in drills …........ Peas, Field or Canada, Pepper, 1 oz. to 1,500 Pumpkin, $i$ ozs. to 100 hills $\because \ldots \ldots$ to $100 \mathrm{ft}$ of drill

Rape bioalcast

Rye broadcast. . . . . of drill $\cdots$ irills $1 \%$ Spinacl, in drills, $10 z$. Sunflower $\ldots \ldots \ldots \ldots$.
Squasli, Bush, 1 oz. to
100 bills ...........

Squash, Running Varieties, $8 \mathrm{oz}$. to 100 hills

Tomato, Seed, 1 oz. to 3,500 plants

Turnip, 1 oz. to $200 \mathrm{ft}$

Turnip, broadcast..

Vetches, broadeast

wleat, broadeast.

Clover, Together

Timothy, for

clover, For One

Timotly, For Ane

For One 6 lbs. Red Top
No. Quity to Bu. Acre

56 lbs. 2 bu 60 Ibs. $11 / 4$ bul. 60 lbs. உ bu ti ozs. $\pm \mathrm{lbs}$

0 ibs. 3 lbs. 56 lbs. 11\% bu. 50 lbs. 25 lbs.

$\ldots \ldots 2^{2}$ lbs

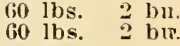
6 lbs. Clover 8 lbs. Timothy 6 lbs. Clorel. 6 lbs. Red Top Slbs. Timoth $\ldots \ldots+\mathrm{lbs}$.

Cnited states Food Administration License, No. G 0623\%. INDEX

For General Information, Ordering, Remitting, Shipping, Parcel Post Rates, Etc., see Page 2. Directions for Cultivating egetables, see Heading of each item.

\section{VEGETABLE SEEDS.}

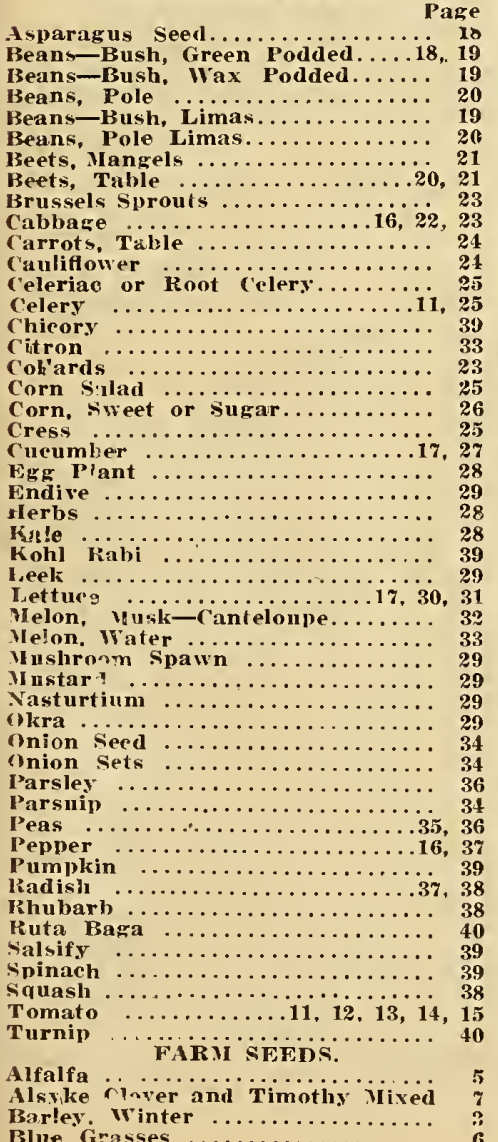

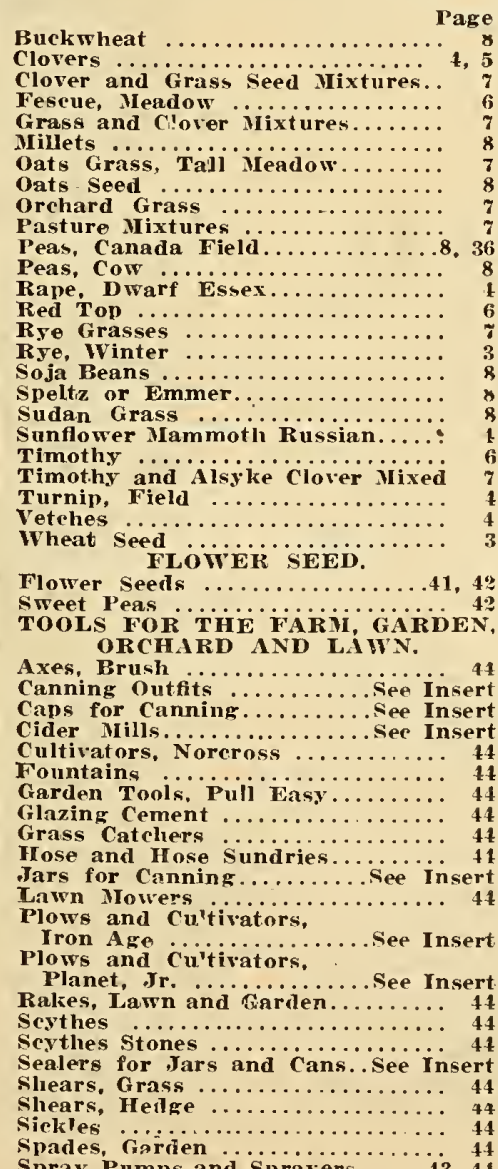

Watering Pots

Pangr

Wheel Barrows Fífiziz:

Blood Meal

Bon Arbor . Fone Larn Fertizer

Farm, Garden \& Lawn Fertilize. 10 Lime for Lawns.

Mulford Cultures

Sheep Ianure INSECTICIDES

Bug Death $\ldots \ldots$
Kil-Fly So-Bos-So

Kil-Fly s
Nikoteen

Oreliard Brand Inseeticicle

Paris Green

Pyrox

LAWN GRASS SEEDS.

Bolgiano's Druid Hi!I Park Lawn Grass Seed

Cloverless Lawn Grass Sped.

Golf Mixtures

POUITRY \& POUT'T

Boxes, Grit and shell.

Brooders Clicks, Day oid.

Coops Sllipoing

Eggs for Hatching.

Eggs, Nest.

Feeds for Ponitry and Pigeons.

Fountains, Drinkin

Hovers

Hoppers, Poultry

Horse and IIule Feeds.

Incubators

Leg Bands for Poultry and

Pigeons

Pills ....................

"Square-Deal"

Poultry Remedies.

Ponltry, Thorouglibre

Roofing

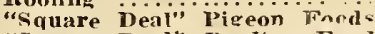

"Square Deal" Porttr. Fond

Stork Foods, peomle.

Water

Water G"asc $\cdots . .$.
Wire. Polltri and Pigenn
Dog and Cat Remeip...........

Ege Boxes, Parcel Post.

44
41

10 


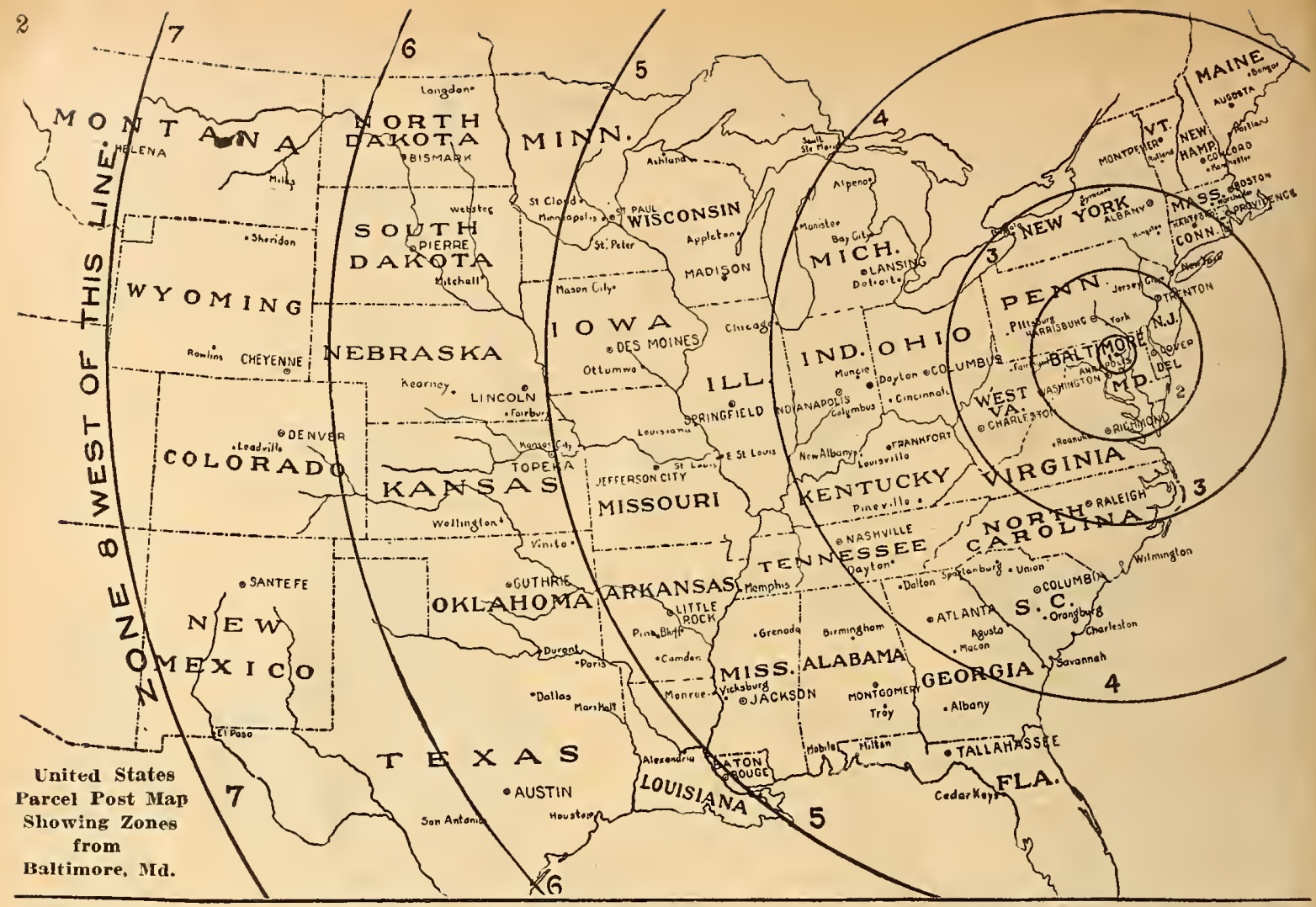

WE WILL PAY WAR TAX ON PARCEL POST PACKAges, As a Courtesy to Our Customers and as an Appreciation of Their Trade, We Will Pay the Now Wair Tax on All Parcel Post Packages Ordered from Us. UNITED STATES PARCEL POST RATES-FOURTH-CLASS MATTER SEEDS, PLANTS, BULBS, ROOTS, GARD EN, LAWN AND POULTRY SUPPLIES Rate Table $\begin{gathered}\text { First } \\ \text { Lb. or }\end{gathered} \begin{gathered}\text { Each Addi- } \\ \text { Fractional Lb. or } \\ \text { Fraction }\end{gathered}$

Local Rate Balto. aud Suburbs ouly
1st Zone within 50 miles Balto. City 2nd Zone witbin 150 miles Balto. City 3rd Zone within 300 miles Balto. Cit th Zone within 600 miles Bilto. City itb Zone within 1,000 miles Balto. Cit ith Zonc within 1,400 miles Balto. City itl Zone within 1.800 miles Balto. City On most of the articles listed in this Catalogue we have gi 'en the mailing weight. By referring to the Pareel Post Map above you can easily see in what zone you are lo cated, and from Rate Table you can easily determine the amount of postage required.
SIZE OF PARSEL THAT CAN BE SENT BI PARCEL POST

Size of package that can be sent by Parcel Post cannot be over 84 inches in length and girth combined.

The rate of postage on mailable parcels of seeds, cuttings, bulbs, roots and plants weighing 8 oz. or less, shall be $1 \mathrm{c}$ for each $2 \mathrm{oz}$. or fraction tbereof, regardless of distance, and on those weighing more thau $8 \mathrm{oz}$. the ponnd rates showl in table shall apply.

\section{WEIGHTS BY PARCEL POST}

Parcels wp to $70 \mathrm{lbs}$. can be sent by Parcel Post in the local, 1st, 2nd and 3rd zones and up to $50 \mathrm{lbs}$. in all other To points further than the 2 nd zone on weight of over 10 Ibs., the charge by freight or express is usually more ecouomical.

\section{HOW TO ORDER BOLGIANO'S SEEDS-READ CAREFULLY}

we Fill crders of All Values, from the Smallest to the Largest, and All Receive tle Same Careful and Prompt Attention. l'rices in this Catalogue are Subject to Market Changes-Special Quotations Promptly Given.

FREE DELIVERY 135. MAIL. We deliver free to any Inited states all Vegetables and Flower sceds otfered in this Catalogue by the packet, onnce, quar ter-pound, and all varieties of Tomato and Cabbage Seed in any size package, inclisding pounds. On all other seeds for half-pounds and uprials the Pircel Post table will 1) 1 ly

When Best to Order. We are fully equipped for filling orders and snpplied with New Crop Seeds. Order at once, so that you can hare your seed on hand ready to start planting your crops at the proper ime without delay.

The cost of lour postoffice or express money order may, on all orders orer $\$ 1.00$, be deducted from the amount. One or Two Cent Postage stamps. We will accept the ame as cash. Do not send other kinds.

If Lou Live on a Rural Mail Ronte, just give the letter and the money to the mail carric and he will get the money order at the postoffice and mail it in the letter for

Use Our Order blank If You Ilave one. If you haren't use any plain paper.

Tel! U's In Your Osil Way What You Want, in any languige. Enclose in your letter the amount of money either a postoffice money ordcr, which vou can get at the postoffice, an express money order, which you can get at the express office, or a draft, which rou can get at any bank, or put the money in your letter, take it to the

Be Sure to Sign Your Name and Address. If br boa railroad say distinctly which lost or railroad to ship by, and if freight has to be prenain all this :molnt to your order to prevent delas.
Market Gardeners. Farmer's' Clubs and Institutions wanting to purchase Seeds in unusnally large quantities should write for suecial prices. We hare made prices very low in this Catalogne yet when a number of bushels or pounds are wanted we can frequently supply at lower price than by the single pound or bushel. In writting give ins a list of quantities and varieties required, and we will return list promptly with our lowest price for the lot

Always Remember That We Can Save You Money, No Matter Where You Live. Write us about any seed you would like to know of, and your letter will be answered the same day it is received. If you wisl to know exactly what the freight or express world be on any article to your station, write us and we wi!l tell you.

As TO WARRANTx, We Helieve Our seeds will proluce for you the best crops you have ever grown, and to show you what confidence we have in our Seeds, if they prove otherwise than represented by us, we will refill your order free of charge; but it must be agreed that we do uot warrant the crops grown therefrom, either expressed or implied, as to description, purity, productiveness or any other matter, and we will not be in any way responsible for them. If the purchaser rloes not accept our seeds, etc.. on these terms, they are at once to be returned and the money that has been paid for the same will be refunded. We appreciate your orders and they receive our proinpt ittention.

GUARANTEE. We Guarantee All Shipments of Seeds cluding Parcel post packages, when remittance accom wies order. to reacli the pirichaser in good condition. 


\section{Bolgiano's Field Seeds for Fall Planting}

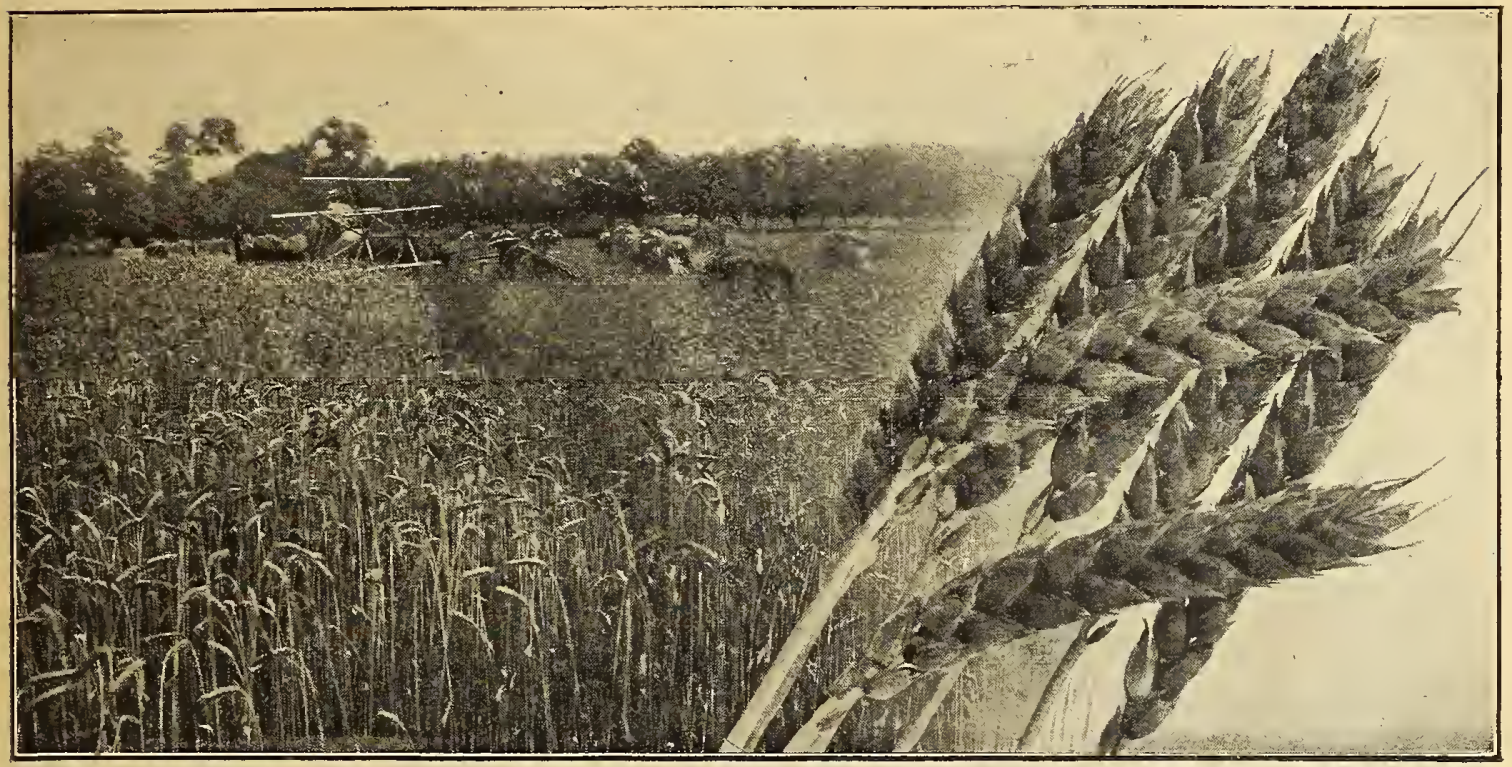

\section{Bolgiano's "Big Crop" Seed Wheat}

Please Write Us for Lowest Prices on all Seed Wheat.

Special Quotations Promptly Given

Leap's Prolific-A splendid new variety. It is remarkable for its productiveness and fine quality of grain. The grain is flintier and of better milling qualities than the grain is dintier and of better milling qualities than the strawed, healthy, strong grower and early to ripen. One strawed, healthy, strong grower and early to ripen. One stooling qualities, it being particularly superior in this respect, producing more stalks to plant than the ordinary wheats. This, with the fine, long heads which it produces, means an increase in productiveness, and farmers who have sown this variety are enthusiastic in its praise, claiming it to be the best and most productire variety now on the market. We can recommend this wheat as being suthe market. We can recommend this wheat as being superior to other beardless wheats. It has proven its merit vield averages on good land nearly ten bushels to the acre more than other smooth-head wheats.

\section{SMOOTH-FEAD OR BEARDLESS VARIETIES}

Hairvest King. Grain is a little larger and it is better milling wheat than other short berry wheats. It is really a beardless long berry variety. the grain being as large and $s$ good, if not of better milling qualities than the Lancaster and Fulcaster.

Fultzo Mediterramean. This is a cross of the Fultz and Mediterranean Wheats. The berry is plump and red chaff white and smooth. Heads of medium length, very compact and well filled. The Fultzo-Mediterranean stools well; the straw is long and extremely stiff. Coming from two vigorous, hardy varieties, it is believed to have derived the good qualities of both. It ripens early and has prived the good qualities of both. It ripens early and has ploven a
tiveness.

Currells Prolific. It is highly recommended by the Kansas. Maryland and Pennsylvania Experiment Stations. Yields from 30 to 40 bushels side by side with the varieties vielding 20 to 25 bushels. This wheat is giving unbounded satisfaction throughout the South.

Bjue stem. Fine beardless wheat in high favor in the south. Makes best quality of flour.

Miracle or Stoner-This new wheat originated in the Valley of Virginia, and is one of the best yielding and most uniform growing of bearded wheats. It is particular15 recommended on account of its remarkable stooling out properties. The claim has been made that it is not necessary to sow more than one-half or three-fourths of bushel per acre to give the same results as ordinary wheat. bushel per acre to give the same results as ordinary wheat.
We will state, however, that on our own farms we have found the best results from sowing it at the rate of one bushel per acre. It makes a fine, heary grain, of excellent willing qualities, and has prosed with us to be one of the best and most prolific of bearded wheats. We recommend it with confidence to our customers.
China-The China Wheat is a new beardless variety which has been quite largely grown in Maryland the past year, with satisfactory results, larger yields being reporterl year, with satisfactory results, larger yields being repor
by some farmers even than from the Leap's Prolific.

\section{BEARDED VARIETIES}

Dietz Mediterranean. A superior long berry variety that has rielded well and given the best results in this section. It is one of the best milling wheats in existence and millers always pay the top price for it. It stands adverse conditions of weather better than almost any other variety.

Red Mediterranean. This splendid wheat is very popular in Maryland, Virginia and Pennsvlvania. It yields 25 or more bushels of plump grain to the acre and produces over a long ton of straw per acre. It is very heavy, over a long ton of straw per acre. It
weighing 61 pounds to the struck bushel.

Fulcaster. This is a very valuable and popular cross between the Fultz and the Lancaster. It is one of the most reliable and best yielding varieties. Has exception ally large heads, stands up well and has proven rustproof. It brings the highest market price as a milling wheat.

Lancaster. An old standard variety of long berry wheat, greatly prized by millers, and always selling at the highest market price. It is the hest variety for low or stiff grounds.

Harcest Pride. This long berry whent is known for its enormous yields.

\section{WINTER RYE}

For Winter pasture, early green feed and for turning under as well as for grain. Winter Rye is used all over the Soutb. It ean be sown with success as early as July and as late as the last part of December. It is often sowll at the last working of corn and cotton and makes an excellent and successful crop grown in this way; it also keeps the soil in better condition for succeeding crops by preventing the leaching by the winter rains. Please wite for latest prices.

\section{WINTER BARLEY}

Barley makes one of the largest and most nutritious crops of pasture or hay. If cut before it is fully headed up it will cule splendidly. In nutritious and feeding qualities it is superior to Timothy Hay. During the Winter and Spring it can be constantly grazed and is ready to cut two weeks aheàd of wheat. Please write for latest prices. 


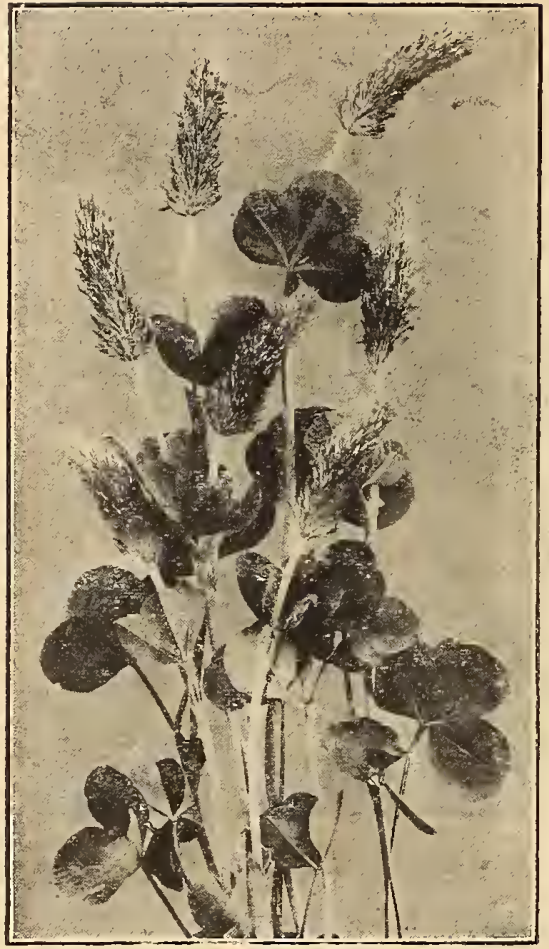

Bolgiano's “Gold Brand" New Crop Crimson Clover.

\section{Crimson Clover Seed}

Crimson Clover. Saves Fertilizer bills and increases the Farmers' Income Millions of Dollars. Sow liberally, either alone or at the last working of corn or cotton. It makes the land rich in nitrugen and $h$ umuss of vegc table matter and puts it in the very best condition for the crops which follow. It also makes a Fine Winter Cover Crop. A Good Eariy forage Crop. An Excellent Grazing Crop During the Late Fali, Winter and Eariy Spring. A splendid soil Improving Crop. Plowed under early ii the spring it increases the yield of corn, tohacco, cotton or other crops whiclu fullow it to a wonderful extent. Thousands of Farmers throughout the yiddle and southern Staces are rapidly increasing their acreage of Crimson clorer they have realized its great value-a crop turned under is equal to a heavy application of stahle manure. The seeds cost so little per acle and the results considered superior even to Cow Peas. Sow during Jurly, Angust or September, 15 pounds per acre. If Crimson Clorer is cut just as it is coming into bloom. tefore the seed forms, it will make a first class Hay" Crop. Crimson Clover can he used for grazing, early green feedl or hay even then the condition aud productireness of the land upon which it is grown will be wonderfulls improved. For Fruit Growers, Corn Growers, Cottou Growers. Tobacco Growers, Dairymen, Truckers and Marké Gardeners, Stock Breeders and Large Poritrymen. Crimson Clover has a marvelous value that as yet has only been partially unclerstood and ippreciated. Share this year in the Great Saving Crimson Clover is annually makin $\mathrm{g}$ for thousands of farmers. New crop seed, large, bright, grolden berries, fine, plump, well matured. Immediate shipment Bolgiano's "Grold" Brand Fancy Crimson Clover. 1 Lb. 22c (Postpaid 28c). 10 Lbs. and over 181/2c. $100 \mathrm{Lbs}$. $171 / 2 \mathrm{c}$ lb. $(\$ 10.50 \mathrm{bu}$. of $60 \mathrm{lbs}$.) Prices fluctuate. Will quote you prices at any time upou request.

\section{Dwarf Essex Rape}

Makey splendid Fall, Winter and Spring Pasturage-Fine for Catt'e, Sheep and Hogs.

Rape for fall sowing should be put in in July, August or September. It makes a large-yielding, nutritious, succulent green feed or pasturage all through the fall, winter and early spring. The fattening properties of Rape are saicl to be very much better than those of clover, and it makes a first-class crop either for sowing alone or for grazing during the fall and winter; can be sown with Crimson Clover. Rape can be successfully sown both in the fall and spiring. Early fall seeding, however, gives the best results Rape is best sown in drills at the rate of 3 to 5 pounds per acre, or it can be sown broadcast, when from 6 to 8 pounds per acre should be used. 1 Lb. 15e (Postpaid 20c). 10 Lbs. and over 111/2c. $100 \mathrm{LbS}$. 101/2c lb. Prices fuctuate. Will quote you prices at any time upon request.

\section{Hairy Vetch (Vicia Villosa) \\ PURE SEED VERY SCARCE}

Vicia Villosa succeeds and produces good crops on poor sandy soils as on good land; grows to a height of 4 io 5 feet. It is perfectly hardy throughout the Cnited States, remaining green all winter; should be sown liberally from July to Norember, with winter rye, oats, wheat or barley, which serves as a support for the plants. It is the earliest crop for cutting, being bardier and nearly a month earlier than Crimson Clorer, and a full crop can he taken off the land in time for planting spring crops. Every Dairyman and Stock Breeder in the Lnited States shoule have a field of it, and if you try it once and see its valup you will never be a season without it. It is exceedingly nutritious, eaten with relish and may be fed with safety to all kinds of stock. Crop short. Write for prices.

\section{Cow-Horn Turnip}

326. Long White Cow-Horn Turnip. It has heen found by practical farmers that there is no hetter way for aerating and adding humus to the soil in the Winter time than by sowing Long White Cow-Horn Trrnips. They can be fed to the stock as they are needed, and the rest allowerl to remain in the ground and rot, haring a valuable fertilizing property. They grow nearly half out of the ground and ile carrot-like in form. Sow two pounds of seed to the icre, broarleast. Pkts. Jc and 10c. Oz. 15c. 1/1 Lb. 2ac I,h. 85c. 5 Lbs. at $75 \mathrm{c} 1 \mathrm{~b}$.

\section{Mammoth Russian Sunflower}

1211. Suntlower has proved to be the best paying crop of anything that has heen planted during the last two years. Sow in March to July, 5 to 10 lbs. per acre. Plant with Corn drills in rows 3 to $31 \frac{12}{2}$ feet apart and thin to 1 plant every 18 to 22 inches, cover very lightly, not over 2 to $21 / 2$ inches, the less the better. Lb. 20c. $10 \mathrm{Lhs}, 18 \mathrm{c} 1 \mathrm{~b} .100$ Lbs. 17i: $1 \mathrm{~b}$.

\section{Spring Vetches or Tares}

1150. Closely associated with Peas in character. Used for the same purpose as Hairy Vetch, but must be planted in the Spring wherever the puinters are severe, as this variety is not so hardy as Hairy Ve ch. Highly valuable for soiling or for green manuring. Sometimes grown with Oats for mowing and feeding to stock. Thrives best in well drained soil, doing best in loams or sandy loans, though excellent crops are grown hoth on sandy and gravelly solls. Sow alone 70 to 90 pounds per acre, and if with Oats 60 pounds of Vetch and 40 pounds Oats. Sow in Spring while the ground is cool and moist or inl early Aur "Yold" lb. Prices fluctuate. W'ill quote prices at any time you request.

\section{Oregon Vetch}

1275. Same as spring Vetch, but owing to its hardiness is known as Oregon or Winter Vetch. It can be planted in the Fall in all of the sotwliern States as well as in the spling with results about the same as Hitily Tetch. Sown alone, sow 70 to 90 pounds per acre. Sown with Oats, sow 60 pounds Veteh and 40 pounds Oats. "Gold" Brand, 1b. 12c (Postpaid 18c). $10 \mathrm{Lbs}$. or over 81/2c lb. $100 \mathrm{Lbs}$. $71 / 2 \mathrm{c} \mathrm{lb}$,

Prices furtuate. Will quote prices at any time upon request.

Sow Scarified Seed and Increase Your Yield

"Will scarify vour sweet Clover or Alfalfa for one cent per bound

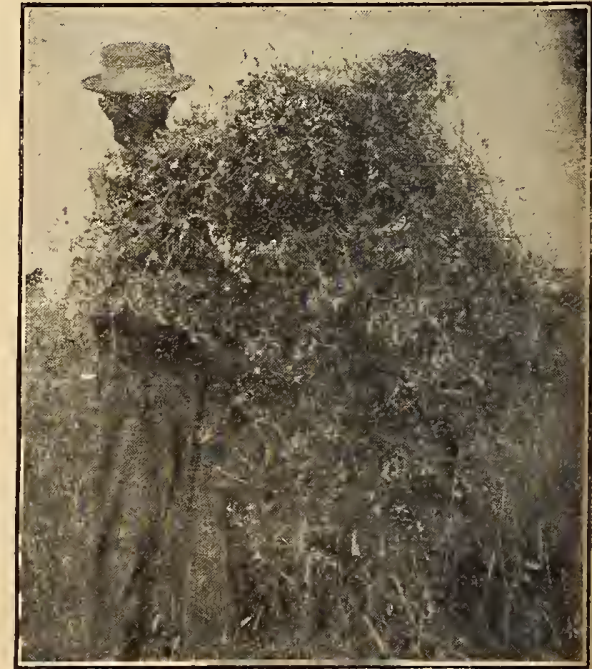

One-Year-old 5-Pound Veteh Font 


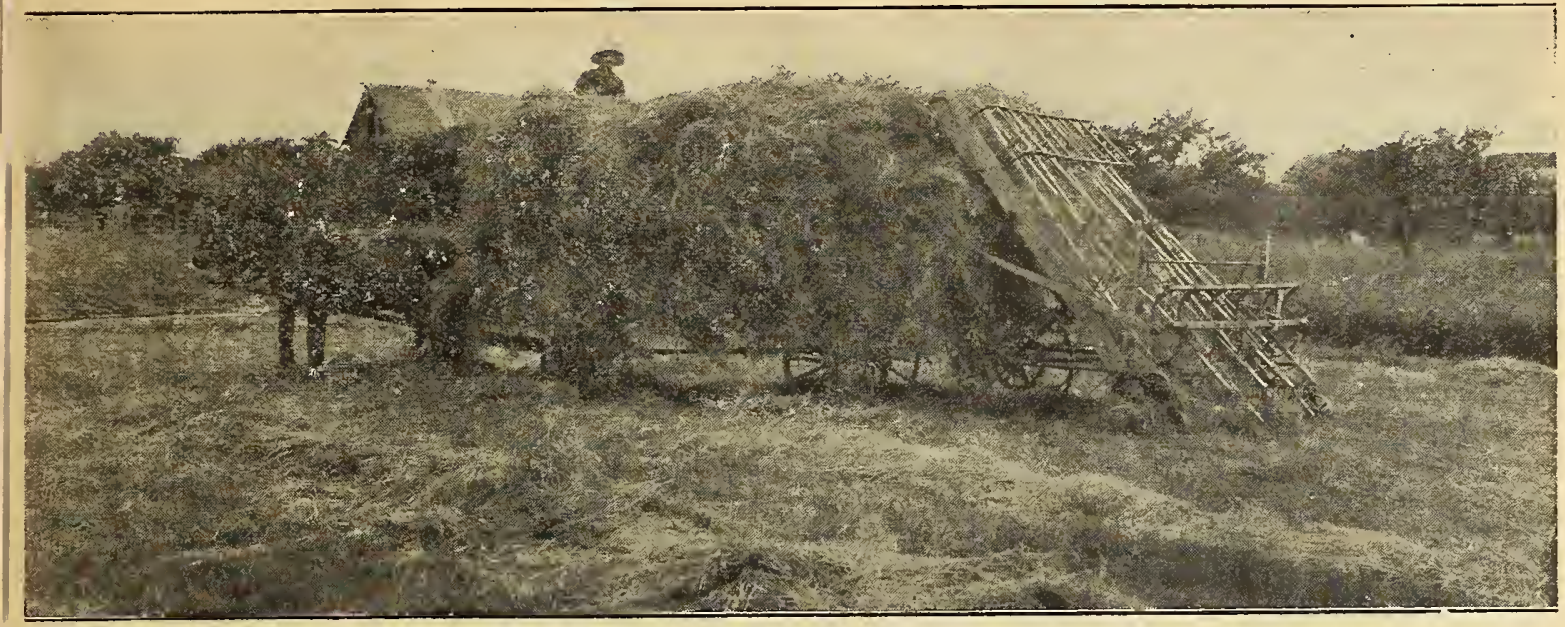

Enormous Crops of Hay are Produced from Bolgiano's "Gold" Brand Alfolfa Seeds

\section{ALFALFA}

Une of the most valuable leguminous hay and forage cops cultivated in the United States. It has been grown experimentally and successfully in every State and Territory. It is a strong perennial plant, which is able to live thirty years or more under favorable conditions when properly cared for.

The proper development of Alfalfa largely depends on the soil. It ean he grown on many kinds. From sand or sindy loams to heavy clays. It thrives best in deep loams with open, porus sub-soil, where tap roots are no hindered, as the root penetrates to a considerable depth. The quality of the sub-soil is of great importance. If it is compact and impenetrable it will be a serious ohstacle to successfur Alfalfa growing. The soil must, therefore, be kept well drained, especially in early Spring. In poorly drained field Alfalfa will be injured and sometimes killed in the low spots where water has accumulated. Alfalfa like other leguminous plants, depends on the bacteria or nitrogen for its vigorous development. Therefore, it is necessary to use bacateria inoculation in treating the seed hefore sowing. This will supply the young plants with the necessary nitrogen for a quick start, and will prove advantageous to your stand of Alfalfa.

The seed bed should be thoroughly prepared. One of the best ways to prepare your land for Alfalfa is to sow cow peas and soja beans ahout May $15 \mathrm{th}$, plow the forage under. harrow aud roll immediately after plowing to hold the bacteria under soil that are in the nodulus on the roots of the cow peas and soja beans. This forage should be plowed under not later than the 15th of August. After the rolling, ground stone lime should be used at the rate of $1,000 \mathrm{lbs}$. per acre. It will be best to apply the lime through a dill and roll immediately after liming. This will give rou a solid seed bed for sowing your Alfalfa the last of August or the first of September. Twenty pounds should be used to the acre and be very careful not to cover the seed more than one-half inch.

Bolgiano's "Gold" Brand Alfalfa seed that we are offer ing is non-irrigated seed hest adapted for all localities.

1 Lb. 30c (Postpaid 35c.). 10 Lhs. or over 26e $1 \mathrm{~b} .100$ I.hs, or over $25 \mathrm{c} 1 \mathrm{~b}$. $\$ 15.00$ for $60-1 \mathrm{~b}$. hu.) Prices fluctuate. We will quote prices any time upon request.

1130. Medium Red Clover. This is regarded as the most raliable of the Clover family and is largely used for pasturage and hay. Clover adds greatly to the fertility of the land on which it is grown. It does not exhaust the soil, but enriches it. It makes two crops each year. The first is usinlly cut when it is in blossom for hay. The last crop may be harrested for seed, eut for hay or plowed under to add ferility to the soil. For Hay it is particularly well adapied for sowing with Orchard and Tall Meadow Grass, as it ripcs at the same time, and sowing these three grasses together will give larger yields and better quality hay than sowing either alone. It is also largely sown with other srasses, both for hay and pasturage. Information as to qua?ities required per acre when sown in combination with other grasses will be foumd under the heading of Orchard Grass, Tail Meadow Oat Grass and Timothy. When sown by itself. sow 10 to 12 lbs, to the acre, either in the Spring or Fall or at the last working of Corn. Price: "Gold" Brand Fancy Red Clover Sced, Lb. 50c (Postpaid 55c.). 10 Lbx. or over $48 \mathrm{c}$ lb. $100 \mathrm{Lbs}$, at $47 \mathrm{c}$. (\$28,20 per bu. of 60 lbs.). Prices flucinate. We will quote prices at any time upon rquest.
1131. Mammoth or Sapling Clover. Is similar to Red Clover in appearance of seeds and habits of growth, the difference being larger growth and later maturing. It is often used for hog pastures. As a soil improver to plow under it is considered superior on account of its extra growth. It is a good variety for thin soils or to seed with Timothy, Meadow Fescue, Herd's Grass or Red Top, as it matures about the same time as these grasses. Sow 10 to 12 lbs. to the acre when sown alone. Whep sown with Timothy use $6 \mathrm{lbs}$. Sapling Clover and $8 \mathrm{lbs}$. Timothy to the acre. Price: "Gold" Brand Fancy, Lb. 50c (Postpaid 55c.). 10 Lbs. or over $48 \mathrm{c}$ lb. 100 Lbs. at $47 \mathrm{c}$ lb. $\$ 28.20$ per bu. of 60 lbs.) Market fluctuates. We will quote prices at any time upon request.

1132. Alsike Clover. Alsike Clover grows thicker and is finer in growth than Red Clover, making better hay and probably more and better grazing. It is also hardier, resisting extremes of heat and drought and also sererely cold weather to a remarkable extent. It is perennial and does weather to a remarkable extent. It is perennial and does
not Winter kill. It succeeds on a variety of soils, light not Winter kill. It succeeds on at variety of soils, light do better on moist land than any other Clover. It is surer to give a good stand and make good crops than either the Red or Mammoth Clover, and in sections where these Clovers have been uncertain Alsike is superseding them altogether. When sown with other grasses it forms a quick undergrowth and greatly increases the yield. It is well adapted for sowing with Red Clover, Timothy, Herd's Grass, as it matures with these grasses, but flowering a little later than Red Clover. Price: "Gold" Brand Seed, 1 Lb. 55e (Postpaid 60c.) 10 Lbs. or over 51e. 100 Lbs. quote prices at any time upon request.

1133. White Clover. This is largely used in lawn and permanent pasture mixtures, and is indigenous to the soil. throughout the Middle and Southern States. It makes a small, close, compact growth, covering the ground like a carpet. It affords excellent food for bees. Sow in either Spring or Fall. When sown by itself, at the rate of 5 to 6 lbs. per acre. It is better, however, sown in mixture with os. per acre. "t is better, "Gold" Brand Fancy, 1 Lh. 45e other grasses. Price: "Gold" Brand Fancy, 1 Lh.
(Postpaid 50c.). 10 Lhs. or over $42 \mathrm{c}$. $100 \mathrm{Lbs}$. at $41 \mathrm{c} \mathrm{lb}$.

1113. Tapan Clover. We do not recommend this Clover for land that can be sircessfully grown in any grasses or clover, hut on waste land or joor, worn-out soîls it will furnish excellent, nutritious pasturage. Sos at the rate of 10 lhs per acre, in March or April. Lh. 30e (Postpair IVe will quote prices any time upon request.

1205. White Blossom Sweet Clover or Boklora. (Hulled.) Melilotus Alha. A strong growing perenuial of value for green manuring, especially South: also largely grown for the excellent food it affords throughout its season for bees. Sweet Clover will provide more feed per acre than any other form of grass. One talmer declares that five acres of Sweet Clover carried more stock than 40 a"res of Timothy and Clover would. Sweet Clover stands drought well and does not cause stock to bloat. Sweet Clover is especially raluable for building un worn-out soils and grows almost anrwhere excent in acid soils. Sweet Clover is a legume, having the same bacteria on its roots that grow on Alfalfa, consequently it supplies nitrogen to the soil and prepares the way for Alfalfa. Sow 15 to 20 poimds at $25 \mathrm{c}$ lb. 100 Lbs. at $24 \mathrm{c}$ ib. Prices fluctnate. We will quote prices any time upon request. 


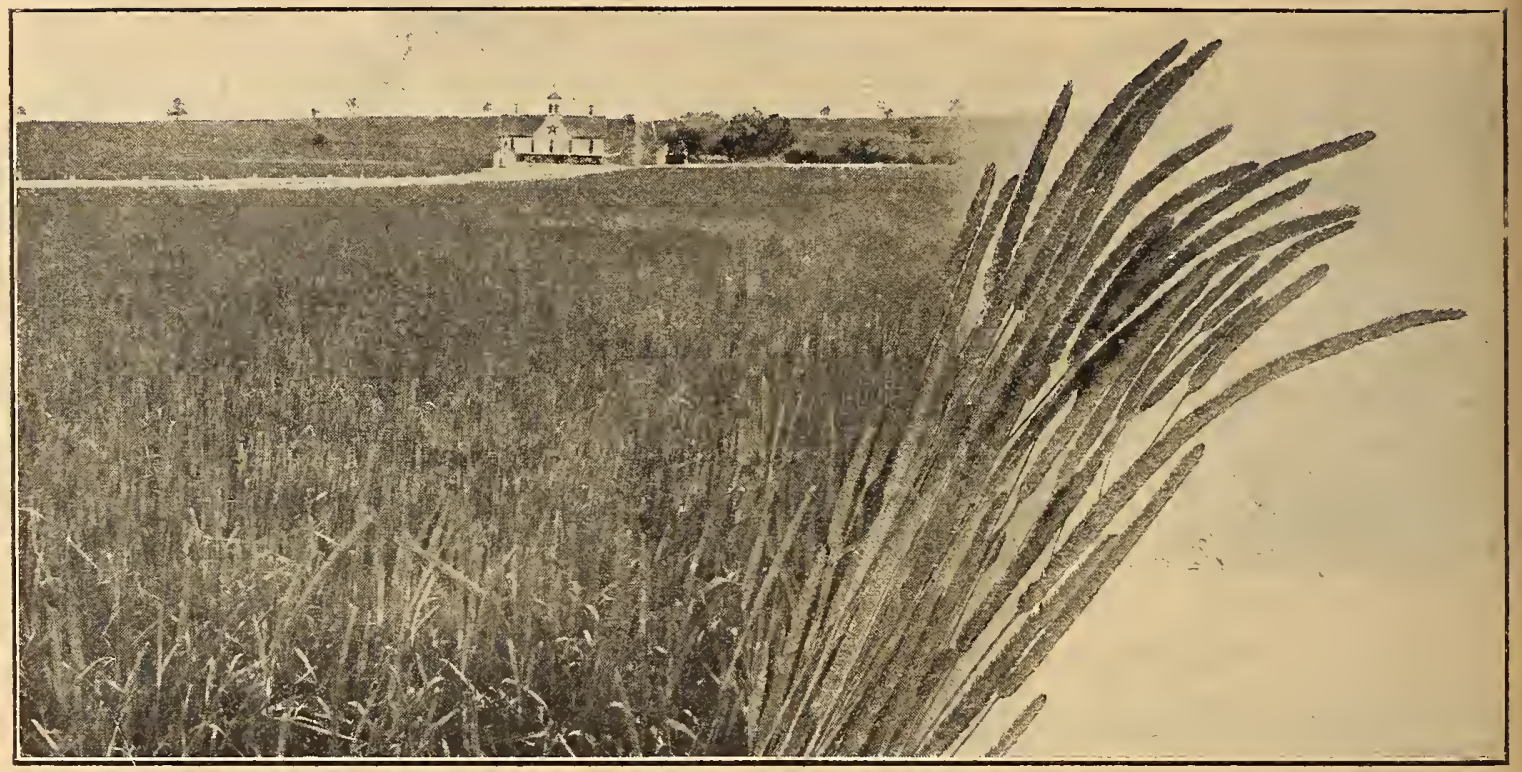

TIMOTHY

1117. Timothy. Of Hay Grasses Timothy is one of the most popular, nutritioms and salable, On clay or heavy loams, lowlands or in mountainons districts, provided there is an abmndance of moistnle, it produces the very best results. On sandy or light loimy ground it does not do so well as orchard, Tall Meadow oat or Rerl Top Grass. so well as Orchard, Tall Meadow Oat or Rer Top Grass. seriously injured, besides it does not form as good graning as many other grasses. The yield of Hay is from $11 / 2$ to : tous per acre. Timothy requires gonalinf to make good rrops. It does not root as deeply and is not considered :ts mucli of an improver as other grasses, consequently should not be sown on land deficient in humms or regetable matter nor on soils of a light or sands nature. table matter nor on soils of a light or sandy nature.
clovers grow well with Timothy and aid it by supnlying Clovers grow well with Timothy and aid it by supplying

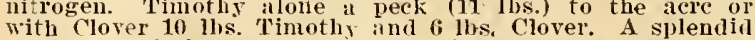
mixture is 8 lbs. 'Timothy, 6 - lbs. Clover (either Mammoth Clorer or Ilsike Clover pleferred, is they mature at the same time as Timotly), (i lbs. Fancy lied Top, $1 / 2$ bu. Mearlow Fescure. 'Together thes will produce most excellent hay, also nutritions and abundant past ure in good clover when sown togetler. Prices: "Gold" Brand, Lb. 20c. (Postpaid 256.). Pk. \$1.75. 1/2 Bu. \$3.25. Pu. \$6.10. 5 Bu. Iots and orer at stino per bir. I'rices thuctuate. we will quote prices at any time nuon request.

\section{KENTUCIKI BLUE GRASS}

1118. Kentucky Blue (irass. This Grass is not only the best for lawn purposes, but makes the swerest and most nutritiois pasture for all kinds of stock. Kentucky has lomg been famous for its ligh-bred horses and its Blue Grass pilstures. It is now possible to establish on most any falm a Bine Grass pasture of greenest verilure which will give very profitable returns. This Grass is the first to start uy in the Spring, and remains green until suow flies in the fiall. It is verg harrly and is unimured by cold or dry weather, hot sim or tramping of loofs. The roots are so thick and stout that they form :l tough sod. Blie Grass requires alont two years to get well started, and for that reason it is often sown in inixture witl other Grasses. It will do well ws almost any land, but does best on well-rlrained clay land. Sow in the Fall or Spring at the rate of two or three bushels per acre.

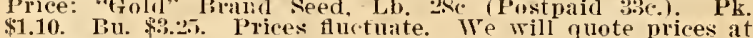
any time tipon request.

\section{CANADA HLIE GRASE}

1120. Canada lilue Grass. liesembles somewhat the Kentucky Blue rrass. It will thrive even on haril chay soil where there is not quite enough lime and fertility for Where there is $110 t$ quite enough lime and feltility for Kenturky Blue frass. and having an excellent root ment Station tlis frass jemained i luxuriant green during the lottest summer when other Glasses were materially affected by the heat. Being a Glass of Camadian growth it stands the cold weather alniliably. Canadian Blue Grass loes not thrive when planted witli closer. Rerl Top and Orrhard Grass ate the best for mixing with it to grow on inferior solls. On good land it becomes tall enough for lay, and as it surinks very little iul dryos hay. and as it slirinks very little in drying the hay is Sow 30 lbs. of secd to the ncre Price: "Fold" Brand Seed,

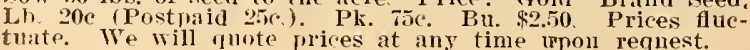

RED TOP OR HERD'S GRASS

1111. Red Top or Herd's Grass. This Grass makes exrellent pasturage and good crop of fine quality hay, and succeeds on a greater variety of soils than any other in general use, giving very good results on light soils. The place for Red Top is on rather moist soil, deficient in liue ilud fertility. It will grow where the soil is too poor for Timothy and Kentulky Blue Grass. It is a good variety to sow with Timothy and Clover for meadow or pasture and is more permanent than either of the other two. It should be fed close, as if it is allowed to grow up to seed the cattle dislike it. On good soil it grows about two feet high; on poor, gravelly land about half that heiglit. it has been crown successfully even on alkali land where it has been crown successfuly even on alkalinas Herd's Giass, should the extensively grown, especially, with other grasses.

Red Top has interlacing, thick roots which male a firm sward not likely to suffer injury from the hoofs of animals. It stands the effect of drought better than Timothy. It is more prermanent if it is grazed off and not allowed to go to seed. For the best quality of hay, it shomld be cut when in full flower. It is more easily cured than almost any other griass. It is rather late in starimg in Siring and matures its crop the same time as Timothy. When it gets well established it sprears and will gradualiy supplant other Grisses. Red Top is also one of the hes grasses for hillsides or lands likely to wash. Oni froid Brand of the Fancy clean Red Top is of extra fine curality, and carefily cleaned from impurities. We can also turnish the Cloice and Prime Fancy Red Top as usimally sold. It lequires about $s$ to 10 pounds to seed an acre of the Fancy Clean seed. When sowing with Timothy. sow 6 pounds of the Fancy Clean Seed and $\mathrm{S}$ pomuds Tinothy per acre. It can be sown cither in the Spriug or Fall "Gold" Brand Fancy Seed, Lb. 200 (Postpid 25e.). 10 Lbs (1) over $171 / 2 \mathrm{c}$ lb. 100 Lbs. or over $161 \% \mathrm{c}$ lb. $\$ 5.00$ for $30-1 \mathrm{~b}$. bu.). Prices thuctuate. ive will quote special prices at any time upon request.

IEADOW FESCIE, RANDALL OR ENGLISH BLEE GRASS

1122, Meadow Fescue, Randall or English Blue Grass It mikes a is particular is particulary raluable for Fall and Winter pastifrage, splendid Spriner and Summer Grass and usnally malies more and thicker leafage than any other Grass. - Grow 2 to 3 feet high, but not in turts like Orcharl Grass. The hay is very nutritious and cattle thrive on it whether dry or rreell Succeeds even in poor soil, and as the routs venetrate deep, from 12 to 15 inches, it takes extremely

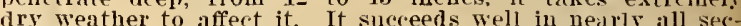
tions of the South, and slionld be very largely used for pasturage and hay inixture. being especially surtable for sowing with lied Top and Timothy for hay, or with these and Orchard and Tall Ieadow Oat for permanent pas tme. Sow either in the Spring or Fall at the rate of 2 mishels to the acre if somn by itself. When sown witl led Top or Timothy sow 1 brshel (1t lbs.) Mleaduw Fescue, Ibs Ifancy Clean Red Ton and o Ihs. Timoth ner acre Sown for grazing mixture with Orchard and Tall Meadow Oat Grass, add half a bushel each of these two fracses. Price: "Gold" Brand, Ib. 26c (Postpaid 31e lb.). 10 r.b. or over 22c. $100 \mathrm{Ll}$. or over $21 \mathrm{r}$ lb. I'rices fluctuate. will quote special prices at an tine unon renucst. 


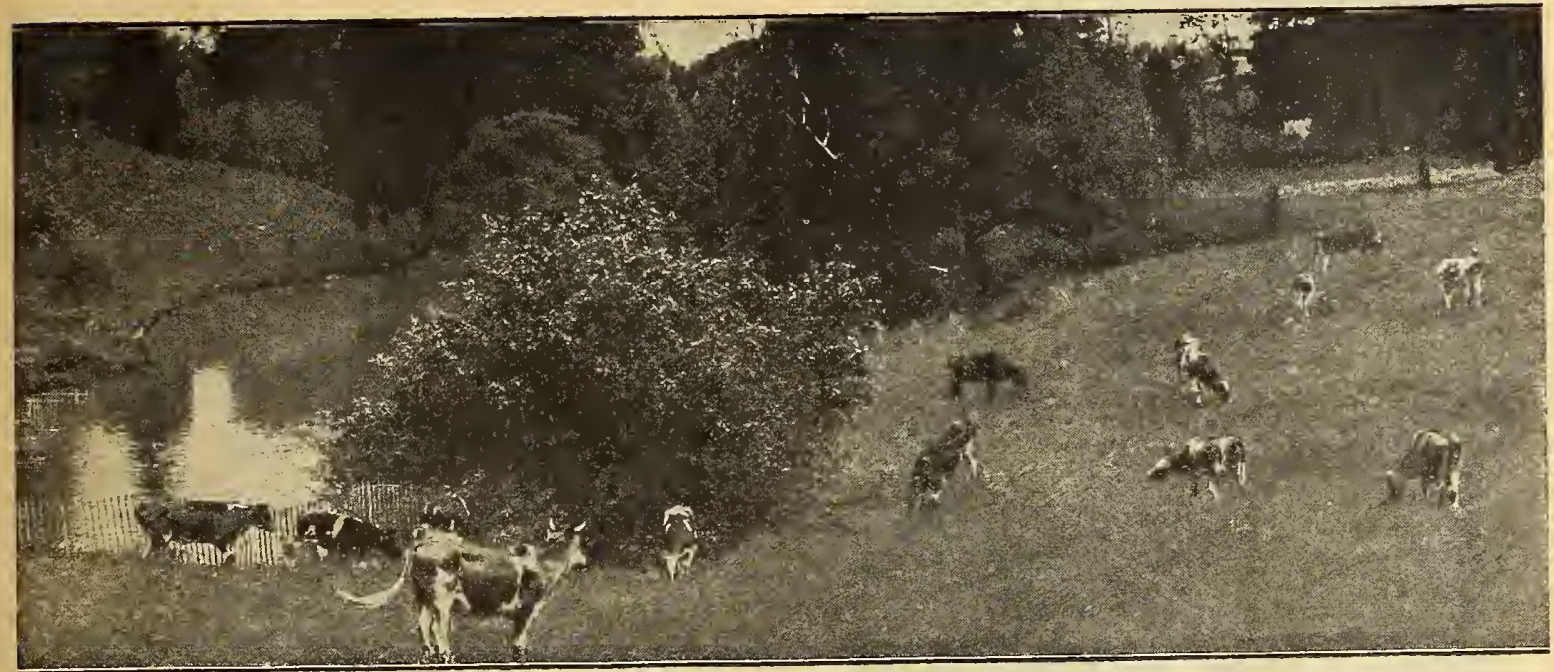

\section{Grass and Clover Seed Mixtures for Hay and Pastures \\ Farcel lost Rates, see Page 2}

These Mixtures give the very best and most satisfactory results to customers, and our trade in them is increasing rapidly. The arlvantages of sowing grasses and clover seed in mixtures las lons been recognized and the practice is increasing to a very remarkable extent thromghout the Soutl. We are the pioneer seedsmen in baltimore in put ting ip special mixtures for differeut soils, and tbe result to our customers have been exceedingly satistactory, resirlt ing in largely increased erops botl ot hay and pasturage. We nill take pleasure in advising our customers as to suitable erassies for their soils and purposes.

We have the following mixtures combiued grasse, uitable for the raus soils aud uses for whicb they are recommended. Those for permanent pastures are composed

Prices fluctuate. We will quote special prices at a

Mixtures for Permanent Pastures---But Can Be Mown 25 Lbs. or over at $100 \mathrm{Lb}$. Rate

Mixture No. 1. For Light, Dry, Gravelly or sandy soils. Sow 30 to 35 lbs to the acre Lib. $20 \mathrm{c}$ (I'ostpaid $25 \mathrm{c}$ ) 10 Lus. at 17c lb. $100 \mathrm{Lbs}$. ilt $16 \mathrm{c}$ per $1 \mathrm{~b}$

Mixture No. 2. For Good Loam Soil. Sow 30 to $351 b$ s. to the acre. Lb. 20e (Postpaid 25e.). $10 \mathrm{Lbs}$. at $17 \mathrm{C} 1 \mathrm{~b} .100$ Lbs. at $16 \mathrm{c}$ per $1 \mathrm{~b}$.

IIxture No. 3. For Heary Loam or Clay Soil Sow 30 to 35 lhs. to the acre. Lb. 20e (Postpatid 25c.). $10 \mathrm{Lbs}$ at $17 \mathrm{c}$ lb. 100 lihs. at $16 \mathrm{c}$ per $\mathrm{lb}$.

Vixture No. 4. For Moist Bottom Land. Sow 25 to 30 lbs. to the acre. Lb. $20 \mathrm{c}$ (Postpaid $25 \mathrm{c}$ ). 10 Lhs. at 17c $1 \mathrm{~b}$ 100 Lbs, at $16 \mathrm{c}$ per $1 \mathrm{~b}$

Mixture No. 5. For Wet Bottom Land. Sow 25 to $301 \mathrm{lbs}$ per acre, Lb. 20c (Postpaid 25c.). 10 Lbs. at 17c lh. 100 Lbs. at $16 \mathrm{c}$ per lb.

Orchurd Grass. One of the best grasses for winter pastures, it makes a good growth on wet and heary clay soils witb ordinary field treatment. lu the first warm dass of February it commeuces a thritty growth, aud if not pas tured is ready to cut for hay in April. With the first Fall rains it springs into life and furnishes an abundance of excellent grazing throughont the entire winter months. 'The hay made from Orchard Grass is of excellent quality and should be cut when in blossom. Sown alone, use 30 to 40 pounds per acre or sow 8 to 10 pounds Red Clover, 20 to 90 pounds of Orcharl Grass mixed per acre It can also he sown with excellent results nith Tall Meadow Oat Grass. Price, "Gold" Brand, Lb. 30c (Postpaid 35c.). Pk. \$1.15. Bu. $\$ 4.00$. Prices. flictuate. We will quote special prices at any time upon request.

\section{Timothy and Alsike Clover Mixed}

Where Alsike Clover and Timothy are grown togetber, and the seed is saved therefrom, it is impossible, iu cleaning, to make a complete separation of the two.

For bay, the Alsike and Timotby Mixture is very valuable on soils too moist for Red Clover. Alsike is suituhle

of grasses whicb succed each otber in growth and give while for those fesired more for cutting for hay bave combiued crisses which ripell together. Iu all our misture bined of Ifalfa clover wit we are introduch wath the idea of inoculating tbe laud with Alifa bacillus. Alfalfa revolutionizes tarming, hut the bacillus must be mixtures are prepared both as to quantity and rarie ie as best adapted to the soils and situations for whicb they are recommeuded lu all of our grass mixtures we use the very best seeds, the qually and pantity bandled enbeing our first consideration. The quantity banded en price, even lower than if they purcbased the seed separately. ne upon request.

\section{Mixtures for Mowing for Hay---But Can Be Grazed} 25 Lbs. or over at $100 \mathrm{Lb}$. Rate

. Iixture No. 6. For Light, Dry, Gravelly or sandy soils. Sow 30 to 35 Ibs. to the acre. lih. 20c (Postpaid 25c.) 10 Lbs, at $17 \mathrm{c}$ lb. $100 \mathrm{Lbs}$, at $16 \mathrm{c}$ per lh.

Iixture No. 7. For Good Loam soil. Sow 30 to $35 \mathrm{lbs}$ to the acre. Lb. $20 \mathrm{c}$

Mixture No. 8. For IIeavy Loam or Clay soil sow 30 lbs. to the acre, Lb. $20 \mathrm{c}$ (Postpaid 25c.). $10 \mathrm{Lb}$ at $17 \mathrm{c} 1 \mathrm{~b}$. 100 Lbs at $16 \mathrm{c}$ per 11

Mixture No.9. For Moist Bottom Lands. Sow 20 to 25 1bs. per acre. Lb. 20c (Postpaid 25c.). 10 Lhs. at 17e. $1 \mathrm{~b}$ 100 Lbs. at $16 \mathrm{c}$ per $1 \mathrm{~b}$.

Mixture No. 10. Shady Nook Meadow Mixture. Like our Shady Nook Lawn Mixture, this mixture is specially prepared for good loamy soil iu partially sbady situations. A fine permancnt pasture mixture, yields large crops of hay. Sow 30 to 35 lbs. to the acre. Lb. 20 (Postpaid 25c.) 10 Tall 1 . 100 Lhs. at $16 \mathrm{c}$ pel $1 \mathrm{~b}$

It is not eadow Oat Grass. Also calied Evercreen Grass. the drought of nid-sumul grass is becoming so popular; iujure it. It starts growing very early in the spring not he cut twice for bay: will vield good grazing imtil late in the Fall. For hay it sbould he cut in bloom. Tall Meadow Oat Grass is best alapted tor lather ligbt and dry loamy uplands, but gives excellent results on nearly all soil. Somn alone, use 1 to :3 bushels to the acre either Fall or Spring: sown in mixture, use 1 husbel Tall Meadow Oat Grass, 1 busbel Orchard Grass and 6 pounds Red Clover. IV rite for prices. . Mixed

for either hay or pasture. It is finer aud more leafy than Medium Red Clover and cattle prefer it. "Gold" Brand,
Lb. 25e (Postpaid 30c.) 10 Lbs. at 17c lb 100 Lbs at 16c lb. $\$ 9.6060-1 b$ bu. Irices fluctuate. We will quote special

\section{Bolgiano's Rye Grasses for Spring Planting}

1121. English or Perennial Rye Grass. A valuable pas ture grass which will bear frequent close cropping. Produces an abundance of foliage. The hay is relisbed by all kinds of stock. It will grow well on almost any land. Wben sowu by itselt sow 30 Ths. per acre either in tbe Spriug or Fall. Price: Lb. 20c. (Postpaid 25c.) 10 Lbs. at $17 \mathrm{c} 1 \mathrm{~b}$. 100 Lbs. at $16 c$ lh. Prices fluctuate. We will quote special prices at any time upon request.

1249. Pacey's Short Seeded Perennial Rye. Specially suited for fine lawn mixture, extensively used ou the beautiful lawns in Fngland. 1t makes a quick, leafy growth

of fiue texture. Please write us for lowest prices

1172. Italian Rye Grass. Like Perennial Rye Grass, valuable for pasturc and also for hay. Tbrives ou rich, noist laud, where from 3 to t cuttings may be uade in a veason. Will stand mole oserflow tban otber Grass. it is less wirs than Perennial Rye Grass and is particularly well irapted to the soils and climale of Florida. Al:out $2+$ los. of seed to the acre. Price: "Gold" Brand, Lb. 22c (Postpaid ite. We will quote special prices at any time Prices fluctuto all kinds of sioch. 
1818-J. Bolgiano \& Son, Seedsmen, Baitimore, Mid.-Fall, 1919.

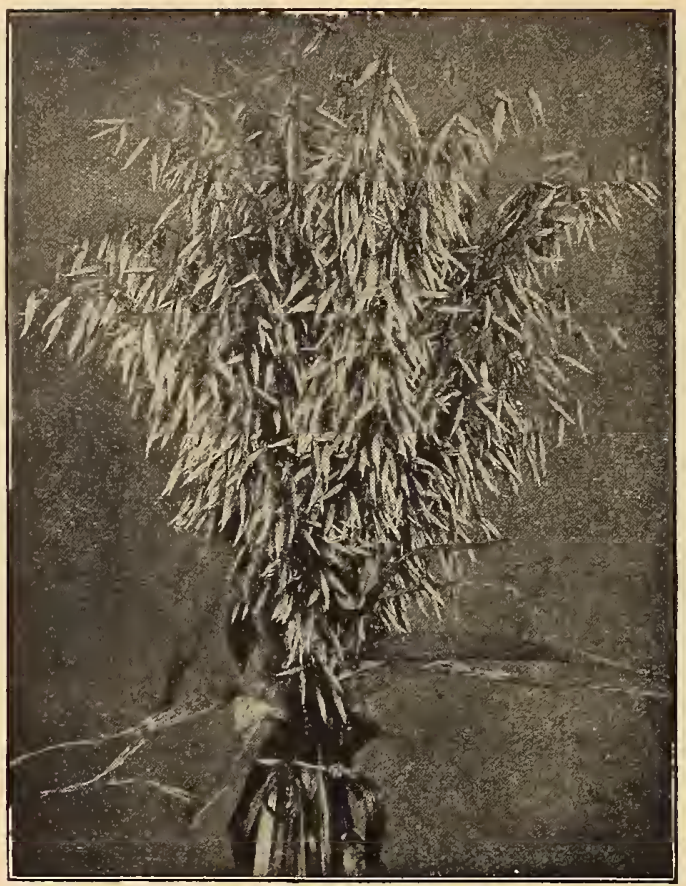

Burt, or 90-Day Oats

COW PEAS

The Great Soil Improvers, make poor land rich, and make good lands more productive, a splendid and nutritious green forage or hay crop, enriching the soil even when the crop is cut off.

Prices fluctuate. We will quote special prices at any time unon recuest.

Mixed Cow Peas. We strongly recommend sowing the Mixed Cow Peas as a soil-improving crop. The upright growing rilrieties holding up the vining varieties, they will make much better crop and give more satisfactory results, yielding better crops of vines and more forage.

Whip-Poor-Will. Vines erect, seed large mottled Red and white and matures early. Good to grow between corn.

lirablam cow Peas.

Soja Beans. The great drought-resisting forage crop; unsurpassed in nutritive value for feeding: also makes a splendid soil improver.

Yammoth Yellow Soja Beans.

wi'son Soja Beans.

\section{CANADA FIELD PEAS}

Canada Field Peas sown in November or December, and covered deeply, come up early in the Spring and grow off rapidly as soon the the weather opens un. Fancy Stock. Pl. \$1.00. Bu. \$3.60.

Prices fluctuate. We will quote special prices at any time upon request.

\section{SUDAN GRASS}

It is a tall, annnal grass, reaching a height of 7 to 9 feet when planted in rows and allowed to mature for seed crop; broadcasted and cut in the bloom for hay about 1 feet. It is easily cured and handled as a hay crop. Stock all kinds eat it readily and will leave any other hay for

The food value is second only to Alfalfa. Three tons cured hay per cuting per acre has heen secnred, and three cuttings made. It is a great drought resister and particularly adapted to semi-arid regions. It is an inual and mus be seeded each spring. When seeded "I rows 18 to 20 inches apart, drill $t$ to 6 pounds. When wn broadcast, 16 to 24 pounds per acre. Bolgiano's Gold Brasd' Seed. 1 Lb. 30c (Postpaid 35c.). 10 Lbs. Ib. $1 \mathrm{c} 0$ Lbs. at $16 \mathrm{c}$ lb. Prices flnctuate. Te will. quote special prices at any time npon requost.
1161. VIRGISLA GRAI WINTER OR TUKF OATS

When sown early, before the Middle of March, these Oals will far outyield the ordinary Spring Oats, making a larger cop and heavier grain. For seed purposes, too, it is most desirable to sow Winter Oats in the Spring, as they betier and cleaner' seed Oats for sowing in the Fall than if continual seedings are made from the Fall-grown Oats. Further North than Virginia remarkable results have been obtained from these Oats, when sown even as late as the first of May, and from the reports of our customers, we strongly recommend these oats to our Northern and Western farmers. as we believe that they will give much larger and better yielding crops than ihe Spring Oats usnally sown in the Northern ind Western States. Sow at the rate of $1 \frac{1 / 2}{2}$ to 2 bushels per acre. Please write us for lowest prices.

1272. Appler Oats. The Appler Oat is equally adapted for sowing both in the Spring and in the Fall, but when sown in the Spring should be sown before the middle of March. It is 2. strong, quick growing Oat, bunchy head and heavy grain. One if the best and most reliable Rust-proof Oats for the South. I'lease write for lowest prices.

BURT, OR 90-DAY OATS

Wherever this Oat is grown it speedily comes into favor. It is free from rust, healthr, clean and vigorous growtl of straw, and makes a remarkable good yield of clean, bright, lears grain. One of the surest cropping varieties of the South. Write for lowest prices.

\section{SPELTZ, OR EMMER}

. Prepare your ground as you wotrld for sow at the rate of two bushels per acre. It is cxtremely hardy and can be sown earlier than Spring wheat or oats, as light frost does not affect it; it can be sown later, but early sowing is better. Pl. 50c. Bn, of $40 \mathrm{lbs}$. $\$ 1.75$.

\section{BUCKWHEAT}

Buckwheat. For a late Summer crop Bnckwheat is very Iesirable and profitable, especially in mountainous sections. It is easily grown, makes splendid fiower food for bees and of a large yield of grain, which can usually be sold for remnnerative prices. As a smothering crop, where the land contains objectionable weeds, it is rery desirable, and it puts the soil in admirable condition for erops to follow.

1160. Japanese Buckwheat. It has the adrantage of remaining for some time in bloom and produces seed earlier. It resists drought and blight very well. As much as 40 bushels to the acre have been harvested, making as 40 bushels to the acre have been harvested, making Bu. $\$ 2.10$

1178. Silver Hull Bnckwheat. A prolific and favorite sort, making a fine quality flour. A superior variety in every way to the ordinary Buckwheat, which it has almost entirely superseded. Please write us for latest prices.

\section{MILLETS}

\section{A Splendid Quick-Growing Summer Hay Crop}

\section{TREE TENNESSEE-GROWN CULTIVATED GOLDEN MILLET}

Anyone desiring to use it for has would be greatly benefited by using our True Temnessee Cultivated Golden Millet in preference to other varieties, as it is fine stock and yroduces more abnndantly nntritious hay than other rarieties. Those people who know the difference or aire always prefer the True Tennessee Golden Millet rather than the commoner sorts, as ther know that the returns from a crop of this kind would he fourfold more than from the commoner variety. It is sown at the same time as the the commoner variety. It is sown at the same time as the other varieties and at the same rate per acre. Onr crop possible condition, and is ready to be sown. Sow one to one and one-fourth bushels per acre, broadcast. True Tennessee-Grown Golden Millet. Per pk. $\$ 1.10$. Bu. $\$ 3.85$. 5 Bus. $\$ 3.75$ per bu

\section{GOLDEN MILLET}

Choice Southern-Grown. True Southern Golden Millet produces a fine crop of the best hay in six to eight weeks time and on good land yields two to two and a half tons per acre. It is of special importance, howerer, to secure the hest Southern-Grown Trne Golden Millet. If common seed is used, or if Golden Millet is mixed with common Millet, the yield is greatly lessened and renders the hay of less valne, because common dillet grows very much smaller, has rery little leaf growth, goes to seed quicker, thus i:1terspersing with the hay woody fibre and more or less seed, both of which are extremely objectionable, besides gratly curtailing the crop. True Golden nlillet produces a large and luxuriant growth of foliage, has very large heads which ripen evenly, and if curt when in bloom is extremely palatable. Sow broadcast one hushel per acre. Two crops can be seeded and grown during the summer on the same land. Price Southern-Grown Golden Millet. Pl. 95e. Bu. \$3.50. 5 Bu. lots \$3.40. 


\section{Inoculate Your Alfalfa, Clovers, Cow Peas, Soy Beans, Vetches and All Other Legume Crops with

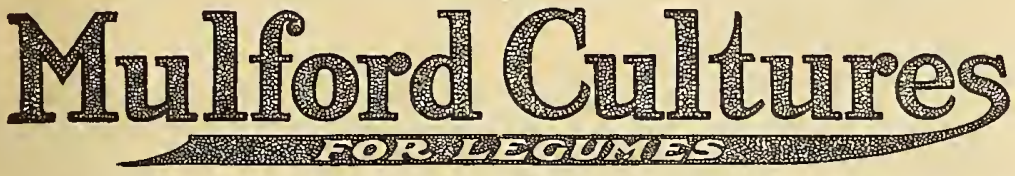

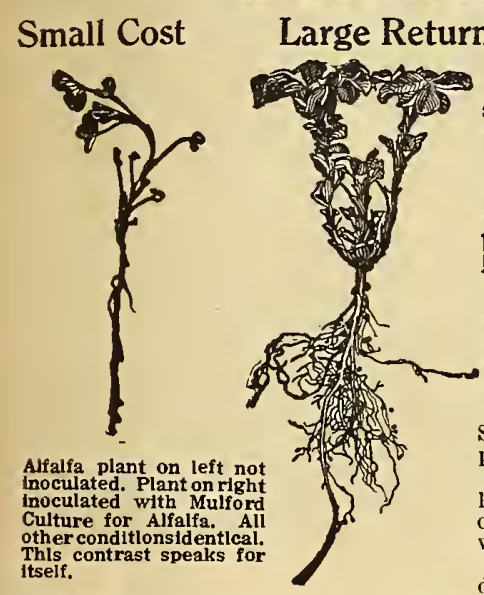

Easy to Use

No Labor Expense

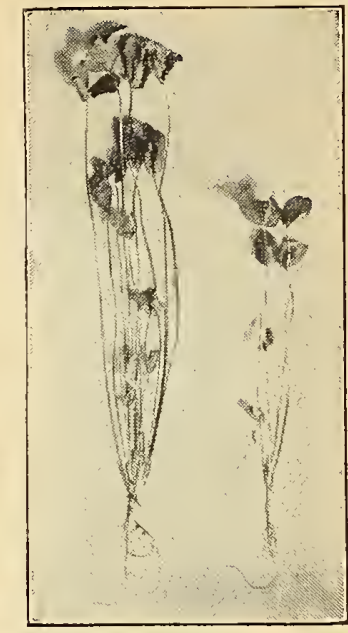
active, vigorous nitrogen-fixing pacteria, for inoculating seeds of legumes or soil. Enormous numbers of these rery valuable and desirable bacteria are thus available to you in every package of Mulford Culture and may readily be applied io your seed. The sealed bottle insures purity.

Increase Your Crops Improve Your Soil

Legumes offer the best-known means of maintaining soil fertility and rejurenating over-cropped and wornsoil and thus increase your yield of wheat, cotton, corn and other non-legune crops.

Inoculated. Not inoculated

Red Clover
Con-legune

The U. S. Department of Agriculture and many State Agricultural Experiment Stations recommend inoculation of legumes with nitrogen-fixing bacteria to induce a prompt "catch" and increase your yield.

Ifulford Cultures are scientifically prepared and tested hy experts in the biological laboratories of H. K. Mulford Co., Philadelphia, U. S. A., with the same degree of care as Mulford Antitoxins, Serums, Vaccines, etc., which are standard all over the world.

Always specify on your order what crop you want to inoculate, as there is a Always specify on your order what crop
different strain of bacteria for each legume.

\section{ALFALFA}

CRIMSON CLOVER SWEET CLOVER WHITE CLOVEF RED CLOVER ALSIKE CLOVER Mammoth Clover

Canada Field Peas
PEANUT

BURR CLOVER
Yellow Clover
Berseem Olover
COW PEAS
SOY BEANS
Canada Field Peas
PEANUTS

\section{VETCH}

Horse Beans

VELVET BEANS

Perennial Peas

SWEET PEAS

GARDEN PEAS
IIIA BEANS

Lupins

Sainfoin

Lespedeza

Beggar Weed

Kudzu

Those printed in CAPITAL LETTERS can be shipped im mediately from stock. The others will be prepared to order and can be supplied in a few days. PRICES

Mulford Cultures are supplied for the varleties of legumes lisied, at the folloning prices:

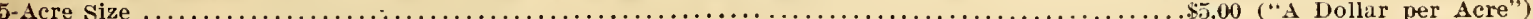

$1 / 1$-Acre Size

Small Size (supplied only in 4 varieties, for Garden Peas, Garden Beans, Lima Beans and Sweet Peas.....

These prices include delivery on Freight shipments.

Why buy expensive commercial nitrates when you can grow legume crops and thus increase your yield and at the same time increase the nitrates and enrich and renovate you $r$ soil, by Nature's own method? FREE DESCRIPTIVE FOLDER SENT UPON REQUEST

\section{Fertilizers for the Farm, Garden and Lawn}

We present a list of our brands of Fertilizers. You can not judge the merits of a Fertilizer only by the analysis, but jou must have a knowledge of the basis from which it has been made.

It is a well-known fact that the animal waste products p roduced in the abattoirs gire the purest and most available hasis for Ammonia and Phosphoric Acid. This is the basis of our goods. The company that manufactures our Fertilizers own and control a sufficient number of abattoirs, independent of the meat trust, to secure for our goods this unexcelled source for our plant food. The expense is almost as much working and reaping one-half a crop as it would be harvesting a furll crop, which a good fertilizer would help to produce.

The four columns in the Analysis represent the following ingredients respectively: Ammonia, Phosphoric Acid, Potash. Bone of Phos. of Lime. Early Truck and Vegetable Grower...................4-8-1-0. Bull Head Fertilizer...........

Corn and Cereal...........................

Corn and Cereal Special......................

Dissolved Organic Comp......................

Sure Grower .................................

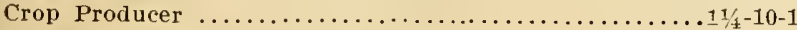

Ammoniated Phosphate .......................

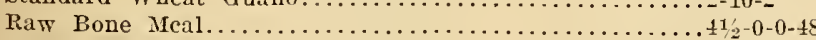

Pure Ground Bone.............................

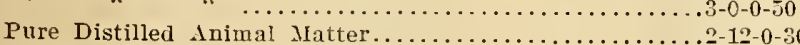

Acid Phosphate .........................

Potash and Soluhle...............................

$\pi$ Soluhle Phosphate $\ldots \ldots \ldots \ldots \ldots \ldots \ldots \ldots \ldots .10-1-0$
40.00

34.00

37.50

29.00

28.50

28.50

12.00

36.00

31.00

30.50

25.00

39.00

63.50

56.50

59.00
11.00

9.50

10.50

8.25

8.25

$\$ .25$

10.00

8.75

8.75

7.25

10.75

17.00

15.25

15.75

12.50

7.00

7.25

7.00

7.25

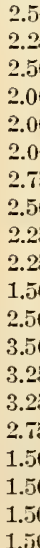

2.250

2.50

2.00

2.00

2.55

2.50

1.50

250

3.25

3.25

2.75

1.50

1.50

1.50 
Used by the Leading Landscape Gardeners of The United States

ANALXSIS AS TO PURITY

TESTED AS TU GERMINATION

If sown this Fall will yuickly proIt is pertectly hardy anc w u kin. It is perfectly har.

Our Druid Hill Park Velvet Greeu Lawn Grass is rery quick ill growth, and is ready for mowing in from four to six weeks from time the seed is sorin.

Lawns sown with our Druid Hill Park Velvet Green Lawn Grass remain green and fresh, for the reason that this mixture includes quickgrowing varieties which are at their best soon after the frost is out of the ground, others that mature and flourish in Midsummer, and still others that are greenest and sturdiest in Autimnn. For each of tbese seasons there are several different arieties living on different elements in the soil, so that one is certain in the soil, so that one is certain of green wherever our Druid Hill Park Velvet Green Lawn Grass is sown.

Not only is our Druid Hill Park Velvet Green Lawn Grass suitable for making of new lawns, but it will be found equally valuable for quickly renewing imperfect, old and Worn-out areas. Alwass see that the soil is thoroughly prepared, carefully pulverized and enriched with Sheep Manure, Bone Fertilizer or Evr-Green Lawn Lime before sowing the seed. One.pound will sow $20 \times 20$ feet, 10 pounds will sow $50 \mathrm{x}$ 100 feet. 60 pounds will sow an acre. 30 pounds measures one bushel. $1 / 4$ Lb. 10c. $1 / 2$ Lb. 18c. Lb. 30e. 5 Lbs. $\$ 1.25$. Bu, of 30 lbs. $\$ 7.25$.

Shady Nook Lawn Grass Mixture

It will quickly produce an abuidant and even growtl of beautiful green grass. The grasses used in making this special mixture are only those that are well adapted for growing in the shade, and as it blends well with our Druid Hill Park Velvet Green Lawn Grass Seerl, it may he used on those portions of the lawn which are shaded hy trees, buildings, etc., thus covering the whole area with a rich green sward. $1 / 4$ Lb. 10c. $1 / 2$ Lb. $18 \mathrm{c}$. Ll. 30c. 5 Lbs. $\$ 1.25$. Bu, of $30 \mathrm{lbs}$. $\$ 7.25$.

For Fair Grounds

SPECIAL GOLF MIXTURES

Over the course, where a rery close-growing sod is not necessary, but where a beautiful, velvety, green grass is wanted, we especially recommend our special inixture for Fair Grounds. By ring this mixture in connection with special mixture for putting greens you are assured an even, velvety, green golf course equal to the best of lawns. Lb. $30 \mathrm{c} .10 \mathrm{Lbs}$. at $28 \mathrm{c}$. $1 \mathrm{~h}$. $100 \mathrm{Lbs}$, or over at $25 \mathrm{c}$ lb

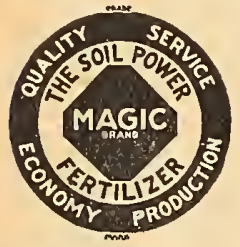

Best Fertilizers

Magic Brand Pure Pulverized Sheep Manure-This is without exception the very best dressing for lawns. The effect is immediate and lasting. It is the only manure that is absolutely free from weel seerls. It is also unequaled as a fertilizer for the vegetahle garden, flower garden, house plants, trees, hothouses, etc. It is also dissolved in water and nsed as a liquid to nourish all kinds of growing plants. Be sure to gire it a trial.

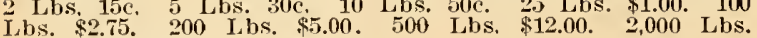
(in $100-1 \mathrm{~b}$. bags) ton $\$ 45.00$,

\section{Bone Lawn Fertilizer}

We have had prefared for us a special lawn fertilizer which is clean and high grade in every respect, and free from disagreeable odors. It produces a rapid and rich greeu growth of grass, and should be somin broadcast in the Spring or Fall. 10 lbs. for 300 square feet; 500 to 1.500 lbs. per acre. Pkt. $10 \mathrm{c} .5 \mathrm{Lbs}, 35 \mathrm{c} .10 \mathrm{Lbs} 60 \mathrm{c}$. 500 Lbs. $\$ 15.00$.

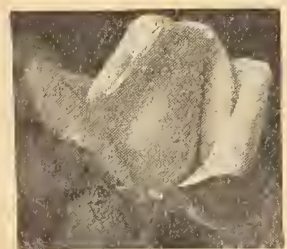

Blood Meal-For Roses

A tablespoonful to be sprinkled around the rose Bush, ahout one inch away from the Bush. every two weeks. It is also rery valuable as a top dressing in the vegetable garden, flower garden, around house plants, trees and in hot houses. $1 \mathrm{Lb} .15 \mathrm{c} .3 \mathrm{Lbs}$. $40 \mathrm{c}, 5$ Lbs. $60 \mathrm{c}$.
Cloverless Lawn Grass Seed
This excellent mixture contains all the valuable grasses composing our Druid Hill Park Velvet Green Lawn Grass Seed. 1/4 Lb. 10c. 1/2 Lb. 18c. Lb. 30c. 5 Lbs. $\$ 1.25$. White Duteh Clover

This is the best clover for lawns, as it forms a close Ilerbage and remains green throughout the seasoll. Sown in the spring at the rate of 6 pounds per acre when sown alone; one-half the quantity when sown with other grass. $1 / 4$ Lb. 20c. $1 / 2$ Lb. $30 \mathrm{c}$. İb. $50 \mathrm{c}$,

\section{For Putting Greens}

What is needed here is a close, low-growing grass that will stand a lot of trampling and will make a springy, tough turf. After thoroughly experimenting and scientifically testing, we have formulated a mixture that will give the desired results of an ideal putting green. Lb. 45c. 10 Lbs. 42c 1b. 100 Lbs, or over at $40 \mathrm{c} \mathrm{lb.}$

\section{for Tawns Flowers, Vegetables,}

BEAUTIFUL FLOWERS, DELICIOUS VEGETABLES, LUXURIANT HOLEE PLANTS

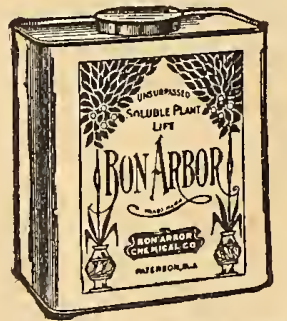

All these Pleasures are Assured if you Use BON-ARBOR, the Ideal Food and Tonic for Householr Plants and Home Flower and Vegetable Gardens-Clean, safe, Odorless, Effective.

Bon-Arbor is immediately soltherefore all the properties are available to plint life from the moment of application. It is quick in action, enabling you to see its effects in from 3 to 10 days on any quick growing plants.

BON-ARBOR is Put Up as Follows:

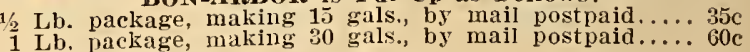

EVR GREEN LATWN LIMIE

One of the Greatest Helps in Making and Retining a rich,

EVR GREEN will renorate old lawns and cure the acidity of the soil.

If the ground is covered with moss and the grass seems sour and unsightlly, sprinkle EVR GREEN freely over the surface and watch the satisfying results. For renewing old lawns it is unequaled. Pake the lawn thoronghly with a sharp tooth rake, sow Druid Mill Park Velret Green Lawn Grass Seed, then sprinkle thoronghly with EVR GREEN and you will soon produce a luxisrious rich green growth. EVR GREEN is put un in $5 n$ lb. sacks. Tise $25 \mathrm{lbs}$. of EVR GREEN to a hundred square feet of sod to get the hest results.

Price: 75 r per 50 lb. bag. 
Bolgiano's Re-Selected and Improved Stock

\section{${ }^{366}$ Livingston's Globe Tomato}

Thousands of dollars are made annually by the Southern shippers on Livingston's Globe Tomato.

The size and shape of Livingston's Globe Tomato makes it a wonderful seller. It is among the earliest and on account of the toughness of its skin, it stands long shipments to Northern markets.

Realizing the adaptability of Livingston's Globe Tomato to our Southern soils and its wonderful shipping qualities, we have spent years in reselecting and improving our stock of this wonderful tomato, until we believe we have the purest and truest tyne of Livingston's Globe Tomalo ever producerl.

In shape it is distinct from all others, being a beautiful globe, with quite a good percentage of elongated (stem to blossom) fruits. It is among the first to ripen. Fruit of large size, and good marketable size is maintained throughout the season; always smooth, firm-fleshed and has very few seeds. Ripens evenly through and through; a fine, glossy rose in color, tinged with purple. The plant is always loaded with fruit, as it has joints at frequent intervals and each joint produces large clusters of from 3 to 7 fruits. Especially adapied for slicing or eating from the hand, as the flavor is very delicate and agreeable.

Pkts. 5c and 10c. Oz. 30c. 14 Lb. 85c. Lb. \$3.00. Postpaid. Livingston's Globe Tomato Seed, saved only from the finest clusters of the earliest stem-set fruit. Pkts. 5c and 10c. Oz. 35c. 14 Lb. \$1.15. Lb. \$4.00. Postpaid.

\section{"Bolgiano's French Golden Self-Blanching Celery} WON THE BLUE RIBBON AT THE SOUTH FLORIDA FAIR HEID AT TAMPA,

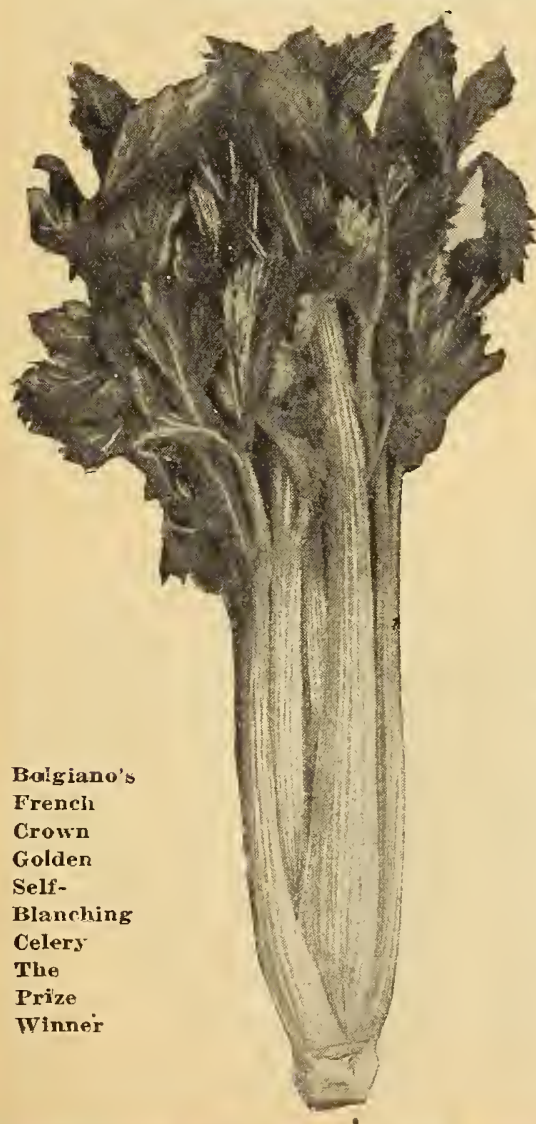

FEBRUARY 15-22, 1919

Otto Gottfried, of Manatee County Florida, wrote: "I sc cured first prize at the Tampa, Fla., Fair, February 15-22, 1919 for the best 10 Bunches of Celery, which I grew from your French Golden, Self-Blanching Celery Seed."

THIS WONDERFUL, CELERY IS USED EXCLUSIYELY BY

THE LARGEST AND MOST EXPERIENCED CELERY

GROWERS ALL OVER THE IVORLD AND AN -

NUAILY PRODUCES ENORMOUS PROFITS.

THIS IS THE FINEST STOCK IN THE IVORLD_STANDS SHIPMENT BETTER THAN ANY OTHER

Many of the Large Growers Around the Sanford, Florida, District Place Their Orders With Us Six Months and a Year in Advance to Be Certain of Obtaining This Perfect Stock of Seed.

BOLGLANO'S FRENCH GROWN GOLDEN SELFBLANCHING CELERY is of the most Superb Quality. Its crispness and tenderness and its delightfully rich nutty appetizing flavor makes it the leading variety in any market. The stalks are large, solid and a beautiful, rich golden yellow, entirely free from stringiness. It is an excellent keeper, stands shipment better than any other sort and brings the highest market prices. It is a vigorous dwarf growers, compact in growth and self-blanching to a very remarkable degree; even the ribs become a handsome, fresh, clean, yellow color, with a heart that is large and solid and of a beautiful rich golden yellow color. - It is quite early and easy to cultivate. In the home garden it produces golden yellow stalks very early, which are crisp, tender and nutty in flavor. It will keep in good condition until Christmas or New Year's. Our stock of this most wonderful celery cannot be surpassed. It is grown especially for us by the originator in France. While it would pay you handsomely to plant your entire acreage in this stock of celery, you cannot afford not to give it a trial. On account of the war conditions in France stock is limited, and we ask you to let us have your order at once in order for you to be sure of securing this most valuable stock. Pkts. 5c and $10 \mathrm{c}$. $1 / 4$ Oz, 25c. $1 / 2 \mathrm{Oz}^{2} 40 \mathrm{c} . \mathrm{Oz}$. $70 \mathrm{c} .1 / 4$ Lb. $\$ 2.10 . \quad 1 / 2$ Lb. $\$ 3.90$ Lb. $\$ 7.50$. Postpaid 


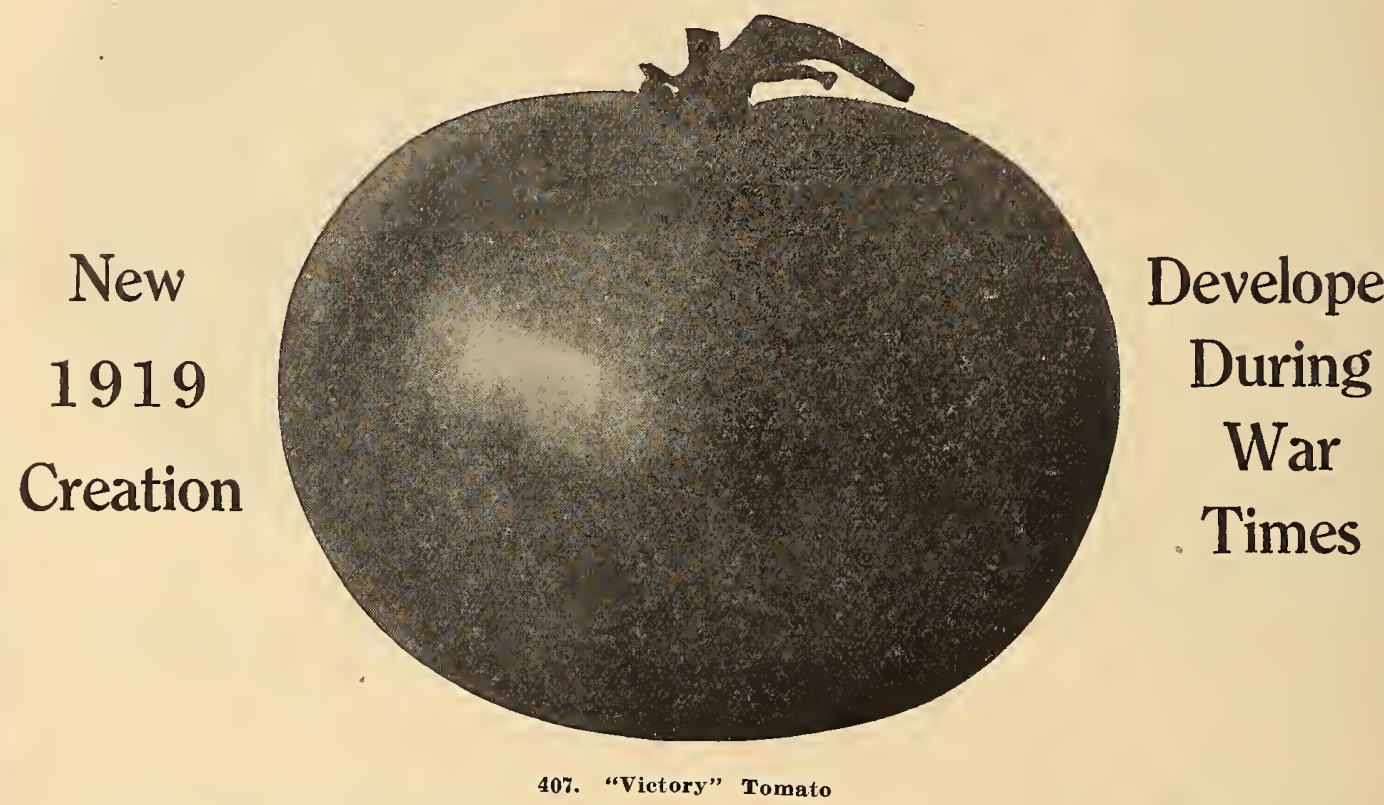

This wonderful Tomato has been created by the World-Renowned Hybridizer and Tomato Seed Specialist, Mr. John Baer. With his only son a soldier in France and with his own heart heavy and sad, this great friend of the trucker and market gardener not only did "his bit," "but "his all," by laboring incessantly during the four long years of the great world war. Meeting failures and successes, he finally cre ated the marvelous "Victory" Tomato.

Carefully considering, all the grand, victorious points of the "John Baer" Tomato and all the splendid, strong, profitahle points of the "Greater Baltimore" Tomato, Mr. Baer set for himself the great task of merging the "John Baer" Tomato and the "Greater Baltimore" Tomato together and creating the most wonderful Tomato the world has ever known.

Mr. Baer has been crowned with success, as will be borne out by the remarkable photograph of the "Victory" Tomato ahove. Mr. Baer has created the most beautifirl, the most prolific the most profitable, the most successful Tomato the world has ever known.

Tbe vines are full of rim, new life and healthentirely free from wilt, blight and disease.

"Victory" Tomato is the product of two wonderful, full-hlooder, healthy parent stocks. The new creation has been selected and developed to reproduce the best qualities of both parents.

It would take many pages to tell about this marrelous new Tomato, for it has never been equaled, but we give below a few of its wonderfully strong points and outstanding good qualities. When you grow it you will say even more good things ahout it than we have.

1st. "Vietory" Tomato is the most beautifully shaped Tomato the world has ever seen.

2nd. "Victory" Tomato is free from core. It produces all perfect high crown fruit.

3rd. The color is a startling, beawiful, brilliant red.

4th. The fruit is firm, solid and beavy. Crowded full of delicious ment.

5th. "Victory" Tomato ripens perfectly right up to the stem.

6th. The derelopment is perfect, smoo:h and eren at both stem and blossom end.

7th. Absolutely no waste.
Sth. Entirely free from wilt and blight.

9th. "Victory" Tomato ripens a little later than "John Baer" Tomato, but earlier than "Greater Baltimore" Tomato.

10th. It is a marvelous yielder. The abundance of its crops will amaze your.

11th. The flavor is distinct, mild, refreshing and delicious, entirely free from any stinging or biting acidity.

12tb. Produces heavy crops of fine fruit when other varieties are complete failures.

Every ounce of our very limited supply of seed has been personally grown by Mr. John Baer, and each Tomato has been selected by bim and the seed saved witb his own hands. Our supply of seed is necessarily a very limited one tbis season, and in order to secure some of this wonderful Tomato, we urge you to mail us rour order immediately. You will be delighted with your crops and receive big profits.

rrices: Pkt. \$1.00. 1/2 Oz. \$2.50. Oz. \$4.00. $1 / 4 \mathrm{~Kb}$. $\$ 15.00$. 1/2 Lb. $\$ 25.00$. Lb. $\$ 50.00$. Postpaid.

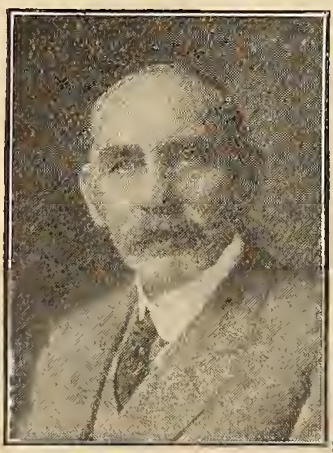

JOHN BAER

The Man Who

Has

Performed

Wonders

With

Tomatoes 


\section{${ }^{24}$ "John Baer" Tomato}

The First Early-Brings Highest Prices

The Best Extremely Early Tomato on Earth Shipping Fruit in 30 Days

"John Baer" Tomato Produces Perfect. Solid, HighCrown, Beautiful, Brilliant Red Shipping Tomatoes

in 30 Days from Large, Strong, Well-Matured Plants Grown in Veneer Bands with Roots Undisturbed

Good Qualities of the "John Baer" Tomato

1st-"John Baer" Tomato produces large, beautiful solid shipping Tomatoes in 30 days from large, strong, well-matured plants srown
Paper bands, with roots undisturbed.

2nd-"John Baer" Tomato produces the most perfect High Crown Tomatoes ever grown. entirely free from core.

3rd-"John. Baer" Tomato produces an enormous crop of Tomatoes, 100 fruit and over to each plant.

4th-Every "John Baer" Tomato ripens evenly, right up to the stem.

5th-No cripples, no scalds, no blight, no cracked, no Trinkled, no one-sided, uneven, scarred fruit, When dead ripe "John Baer" Tomato will not burst.

6th- "John Baer" Tomato has a wonderful glistening, brilliant, bright red color.

7th-"John Baer" Tomato has a mild, deliciously sweet flavor. The finest flavor you have ever tasted.

8th-"John Baer" Tomato is almost seedless; it requires 6 to 8 bushels of "John Baer" Tomatoes to make one pound of seed, a marvelous Stem Setter, often ten fruit in first cluster, solid and meaty.

9th-"John Baer" Tomato has just enough foliagewill stand plenty of manuring withourt going to vine, Set plants $3 \times 31 / 2$ feet

10th-"John Baer" Tomato is the most perfect shipping Tomato ever grown-2t fruit exactly fill a six-carrier basket.

11th-Each beautiful "John Baer" Tomato weighs about $61 \%$ ounces.

12th-"John Baer" Tomato Seed was saved only by John Baer, the originator, who personally selected and picked every Tomato from which he saved this seed, selecting only the most beautiful, perfect fruit of the Early Stem-Set Clusters.

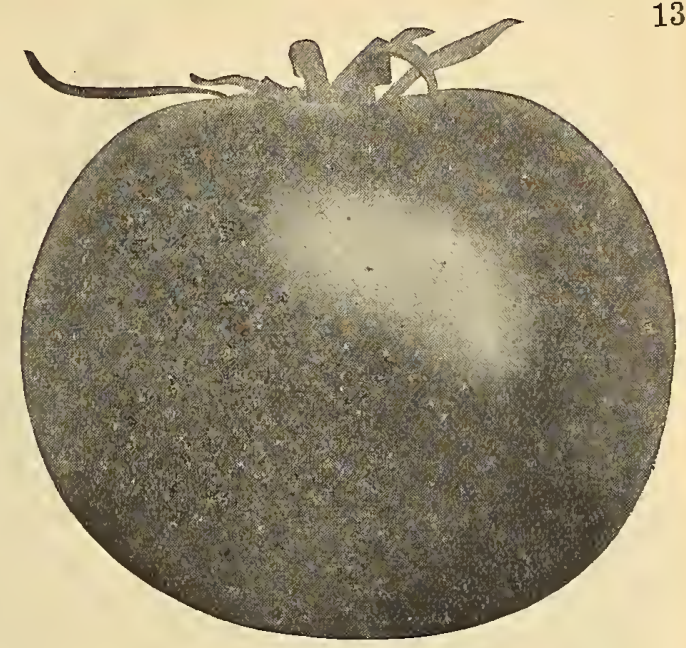

John Baer Tomato

The Best Extremely Early Tomato on Earth.

13th-"John Baer" Tomato is the offspring of two marrelous Tomatoes-one Great Specialist havin devoted 10 years in selecting and improving one devent and Another parting "selecting and improving the other parent. $\mathrm{F}$. "John Gaer" Gomerations of Improvement and Selection for earliness, quality, shape, fruit, color and shipping quality.

14th-As a Packing Tomato, "John Baer" is a miracle -they all pack Fancy, no seconds, and all pack whole. Peelers can prepare three bushels "John Baer" Tomatoes to one bushel of any other Tomato. Being swch a tremendous yielder a bushel of "John Baer" Tomatoes can be orathered in onethird the time of any other Tomato. A large Baltimore Tomato Packer has all the "John Baer" Tomatoes he can secure packed separately, running them through a special process for his fanciest trarle and his own private use.

Prices: Pkts. 5e and 10c. $1 / 1 / 4$ Oz. 25c. 1 Oz. 70e. 2 Ozs. $\$ 1.15$. 1/4 Lb. \$2.10. 1/2 Lb. \$3.90. 1 Lb. \$7.50. Postpaid. We Offer Veneer Bands 75e Per 100.

\section{Pretty as

\section{Lives and Bears Abundantly When Other Varieties Die}

"Glory" Tomato is now being grown by Tomato growers in every State of the Union and in many foreign countries. The reports we have received have been, without a single exception, full of praise and appreciation of the wonderfurl good qualities of this marvelous Tomato.

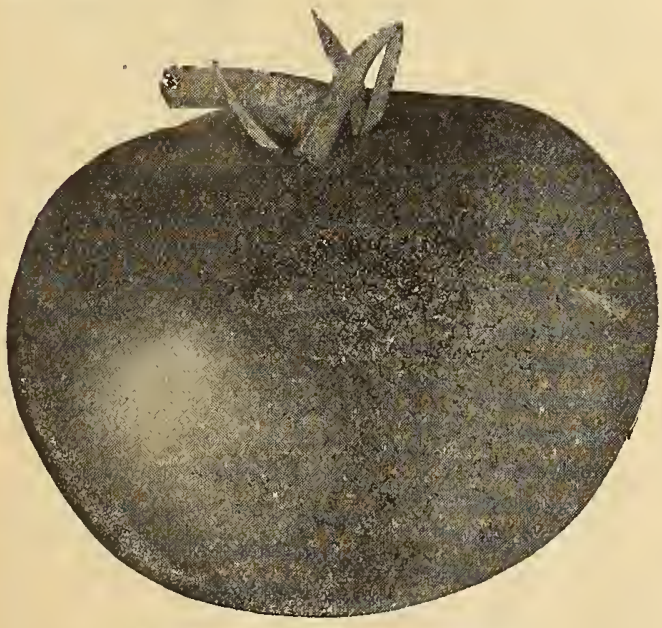

Bolgiano's New Glory Tomato.
"Glory" Tomato produces hut very few seeds; the seeds are therefore well matured full of life and rigor and will germinate quickly and produce strong, rigorous, thrifty plants.

"Glory" Tomato ripens earlier than many other varieties that are usally planted for early use and is an abundant and continuous bearer.

"Glory" Tomato produces vines that are well set with fruit, bearing from the ground to the top of the vine. At times the vines are so full that they can hardly hold all the fruit that they produce. The vines are shortjointed, vigorous and healthy. So pure in type they are almost identical in all respects. They keep vigorous and green until frost and then are full of fruit.

"Glory" Tomato produces at every joint large cluss. ters of good size, smooth, firm, beautifully shaped fruits, uniform in shape, color and size. They ripen evenly and color up well.

"Glor" The vines are fairly loaded with beautifur fruit. Many growers say "Glory" Tomato yields more per acre than any other Tomato: it has produced over 1,000 crates per acre; many single plants produce over 35 pounds of fruit apiece. Side by side with other Tomatoes, "Glory" has outyielded them two to one. Many Tomato growers claim it produced the largest crops they have ever grown.

"Glory" Tomato is decidedly disease resistant. It has proven absolutely blight-proof when other crops side by side were ruined by blight.

"Glory" Tomato is one of the handsomest Tomatoes grown. It has an exceptionally fine Red Color. Mild, Delicious Flaror. The fine breeding and careful selection of this strain shows up in the fruit. It is entirely free from cracks.

"Glory" Tomato being an extremely shy seeder, we suggest sending in rour order as early as possihle before our limited supply is exhausted.

1/4 Lb. \$7.50. 1/2 Lb. \$14.00. Lb. \$25.00. Postpaid 


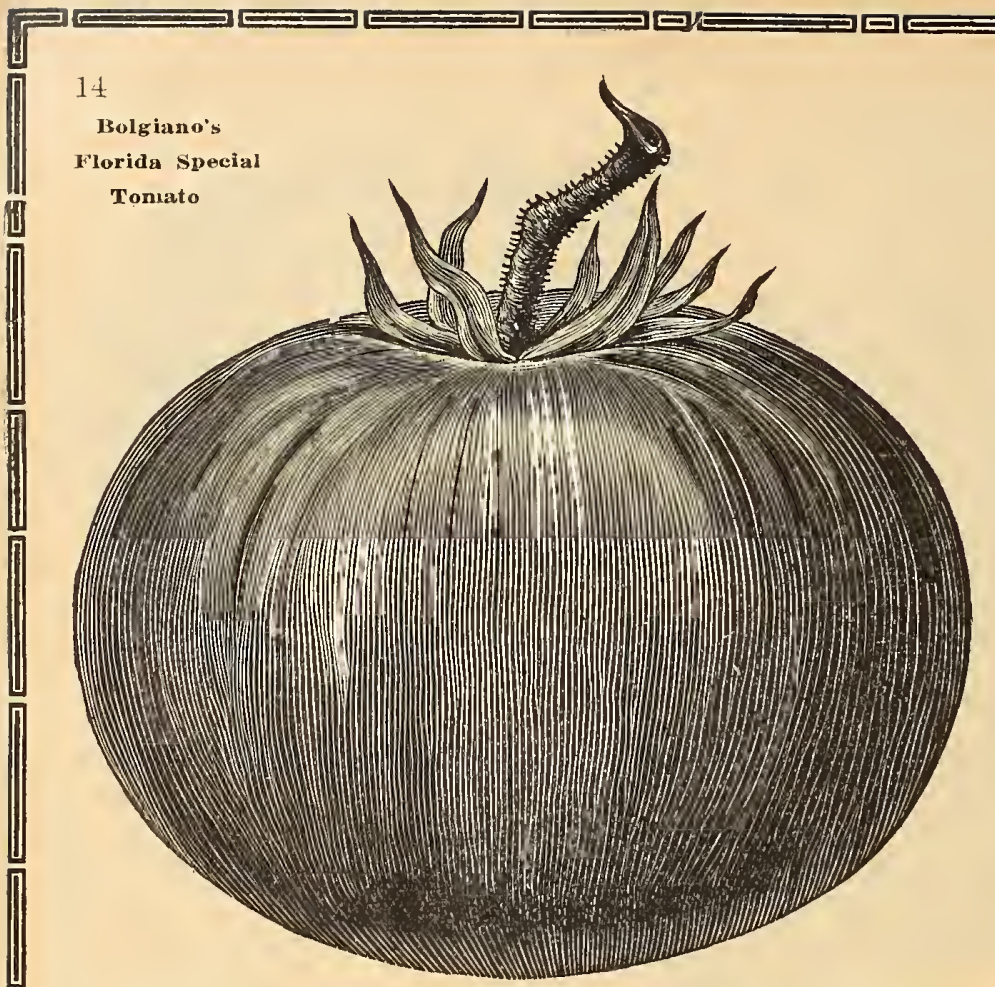

${ }^{311}$ Florida Special Tomato

The Greatest Blight-Resisting Tomato on Earth.

Not a single grower of Tomatoes in Florida or in any locality where bliight has injured the Tomato crops should go through this season without trying this most excellent Tomato. We call it "Florida Special," for it has been most carefully bred up to resist the ravages of blight, which has been so discouraging to our Florida customers. It is red in color, large in size, fine flarored, firm and meaty, very prolific and about and meaty, very prolific, and about excellent shipper; in fact, during our entire time of selecting and breeding up the Florida Special we took the utmost pains in selecting such tomatoes as would stand the long shipment to Northern markets from Florida. Pkt. 10c. Oz. 30c. 1/4 Lb. $85 \mathrm{c}$. Lb. \$3.00. Postpaid.

29\%. "DUKE OF YORK" TOMATO Genuine Old-Type Blue-Stem StockExtra Selected Proven Stock.

Duke of York Tomato is one of the grandest Tomatoes ever introduced, color rich, glossy scarlet, splendid cropper, round in shape, flesh very firm, large size, fine flavor. It ripens its fruit uniformly together. whilst in profusion of clusters, aver aging 8 to 10 large evenly formed clusters each, makes it conspicuously handsome. Ripens evenly to the stem is strong, healthy grower; not subject to rust or blight, is an enormous cropper and prodices until the vines are killed by frost, holding its size well until the last picking. Quality the very best, solid and meaty. The seed we offer of this variety is saved only from the finest clusters of the earliest stem-set fruit. Pkt. 10c. 1/2 Oz. 15c. Oz. 30c. 2 Ozs. 55c. 1/4 Lb. 85c. Lb. \$3.00. Postpaid,

279. BOLGIANO'S "GREATER HALTIMORE" TOMATO

After eight seasons have passed and the "Greater" Baltimore" Tomato has been grown in every Tomato State in the Union and in many foreign countries, it is almost impossible to give a description of its merits without seeming to claim for it supernatural powers, so in describing it we will, as far as practical, confine ourselves to extracts from the experience of those who have mrown the "Greater Baltimore" during the past seven years.

A Florida man writes: "It is the finest Shipping Tomato ever sold-tested side by side, and shipped side by side with five leading varieties, it beat them all." "Another writes: "Out of 15 Red Varieties it was the best of all." Very prolific-it yielded from 300 to more than 650 bushels of 60 pounds per acre." One man raised 17,000 plants from quarter pound of "Greater Baltimore" Tomato Seed. Vigorous grower, strong, healthy plants. Fruit uniform in shape and size, large, very regular, smooth, shapely, fleshy, very meaty, ripens

\section{7. "MY MARYLAND"-BOLGIANO'S WONDERFUL} NEW TOMATO

King of Them All. Has Surpassed the Best Yielding

Tomato in the World More Than 1000 Per Cent - Marvelous Double Yielder.

The rast possibilities of this New Tomato are astounding. We believed in Greater Baltimore Tomato the limit of productiveness had been reached, but "My Marylaud" so far outyields any other Tomato ever grown that its remarkable productiveness is amazing. People hare driven miles to see a field of "Mr Maryland" Tomatoes, and ther all marreled at the prodigious abundance of the crops it had produced. The fields were literally covered with the finest well-shaped, perfectly formed, solid. smooth. brimht red. uniform fruit, all frec from roughness and craeks, much larger than ther had ever seen before. It was called then and there "A Winner," and it well deserved the title. The Tomatoes are much larger and far hearier than either the Greater Baltimore or the New Century. By most careful reselections for five vears we have thoroughly established the purity and trueness of "My Maryland" Tomato, and are delichted to be the introducer of a Tomato which from start to finish is "King of Them A11." A real "Double Yielder" that is known as the best second early and main crop Tomato the world over. Pkt. 10c. 1/\% Oz. 20c. Oz. 10c. 2 Ozs. 70c. Lb, $\$ 1.35$. 1/2 Lb. $\$ 2.40$. Lb. \$4.50. Postpaid. well and evenly. Beautiful bright red color, fruit very handsome, dozens weighing 30 ounces, and several exceeding 32 ounces. Seed planted a month later than "Duke of York" produced shipping fruit two weeks before that variety was ready. "Fine crop in bad season." Excellent keeper-has kept until New Year's Day. Rust and blight-proof. Recommended unreservedly by arower for "the section around Lakeland, Fla" Had proved better than ally variety tried at Picton, Canada. "Stands the heat and drought of Mississippi." "Very valuable for South Carolina climate." In the canning districts of Delaware and Maryland "yielded a fine crop in bad season." Texas says there is no better tomato in size and taste on the market; not an acid tomatovery fine flavored. As a bome garden Tomato the results liave been far beyond expectation. On our own table we sliced the "Greater Baltimore" Tomato like we would slice a fine, tender roast beef. Pkt $10 \mathrm{c}$. $1 /$ Oz. 20c. Oz. 35c. 2 Ozs. 65c. 1/4 Lb. \$1.15. 1/2 Lb. $\$ 2.15$. Lb. $\$ 4.00$. Postpaid.

\section{BOLGLANO'S PROSPERITY TOMATO}

We didn't want to llame this wonderful New Early Red Tomato "PROSPERITY," but we couldnt help it no other name could tell so quickly and so thoroughly how good it was.

"PROSPERITY" means Success, Good Fortune, Fntire and complete Satisfaction; finding a tomato possessing all these qualifications and advantages, we possessing all these qualifications and adva",

Description-One of the earliest of all Tomatoes, a brilliant red, and enormous yielder, grown and dereloped from single plant selections covering a period of five years filled full of strong, sturdy, healthy, new blood. After having been tried by the leading market gardeners and largest shipuers all over the United States and Canada for the last six years, it is today thought more of than ever before. Stock this year is limited so ask that you send us your order at once. limited, so ask that vow send us your order at once.
Price: Pkt. $10 \mathrm{c}$ and 15c. $1 / 20 \mathrm{Oz} .25 \mathrm{c}$ Oz. $50 \mathrm{c}$. $1 / 4 \mathrm{Lb}$. $\$ 1.40$. Lb. $\$ 5.00$. Postpaid.

\section{DWARF STONE TOMATO}

Double size of Dwarf Champion, the largest fruited ipright growing variety in existence. In habit of vine it resembles Dwarf Champion, is of stronger growth and more erect. The fruit resembles Livingstons Stone in color, shape, and, what is more remarkable, is almost the same in size. Prices :Pkts. 5c and 10c. Oz. 30c. $1 / 4$ Lb. $\$ 1.00$. Lb. \$3.50. Postpaid.

\section{0\%. NET STONE TOMATO}

Extra Selected Stock Sared only from the finest Clusters of the earliest Stem-Set Fruit, Pkt. 10c. Oz. ciusters of the earliest Stem-Se 
1. One of the Earliest, Largest, absolutely smooth Tomatoes on Earth. A week earlier than the "Ear

2. A beautiful brilliant red color.

3. Vines are a perfect mass of large. mootl fruit, a single plant yielding 1 bushel.

4. Fruit extremey early, enormously abundant, ripens all at once.

5. Vines compact and can the placed wo feet apart in three-foot rows.

6. As an extremely early prolife stem setter it is a wonder.

\% The absence of unnecessary leaves permits all fruit to ripen so remarkably early.

8. It is almost like finding mones to plant the I. $\mathbf{X}$. L. Tomato.

9. The largest growers tel us that we cannot say ton mucl in favor of the $I$. $X$. $L$. Tomato.

10. In twelve years it has never disappointed a grower.

\section{Red Tomatoes}

28t. Bolgiano's Best. The Great B. B. Tomato. Used successfully for early and late crols. Pkts. $5 \mathrm{c}$ and 10c. 16 $\mathrm{Oz}$ 15c. Oz, 30c 1 Lb. $85 \mathrm{c}$ Oz. 15c. Oz. 30c. $\$ 1.60$. Lb. $\$ 3.00$.

196. Maul's "Earliest of All" Tomato. Extremely early, large size, brigbt red color and delicious flavor. Pkt. 10c. $1 / 20 z .20 \mathrm{c}$ Oz. 30c. ${ }^{2}$ Ozs.

55c. $1 / 4$ Lb. $\$ 1.00 .1 / 2$

283. Bolgiano's New Century Tomato. Deep red color, large, handsome size from first picking until last Tomato is taken from the vine Pkts. $5 \mathrm{c}$ and $10 \mathrm{c}$ last $\$ 1.60$. Lb. $\$ 3.00$. Postpaid.

572. New Red Rock Tomato. One of the finest, large, solid, smooth Tomatoes of rery fine, red color Pkts. 5c and 10c. 1/2 Oz, 20c. Oz, 30c, 2 Ozs, 55c. 1/ Lb. $\$ 1.00$. 1/2 Lb. $\$ 1.90$. Lb. $\$ 3.50^{\circ}$ Postpaid.

332. Bonny Best Early Tomato. This is a very early, and very popwlar variety; it is a rigorous grower, enormously prolific. With splendid foliage and of an intense relvety glowing scarlet color. Pkt. 10c $1 / 2 \mathrm{Oz}, 20 \mathrm{c}, \mathrm{Oz}, 30 \mathrm{c}, 2 \mathrm{Ozs} .55 \mathrm{c} .1 / \mathrm{Lb}, \$ 1.00 .1 / 2 \mathrm{Lb}$ $\$ 1.90$. Lb. $\$ 3.50$.

278. Bolgiano's Extra Early Wealthy Tomato. One of the earliest, smooth. firm delicious flavor. beautiful red color and an abundant vielder Pkt 10c. $1 / 2$ Oz. 20c. Oz. 30c. 2 Ozs. 55c. 1/4 Lb. $\$ 1.00 .1 / 2$ Lb. $\$ 1.90$. Lh. $\$ 3.50$, Postpaid.

287. Chalk's Ea'rly Jewel. Very fine new sort large, solid, smootl, bright red; similar to tbe Stone, but early. Pkts. 5c and 10c. 1/6 Oz. 20c. Oz. 30c 2 Ozs. 55c $1 / 4$ Lb. $\$ 1.00,1 \%$ Lb. \$1.90, Lb. \$3.50. Postpaid.

286. Spark's Earliana Tomato. It is remarkable for its earliness, very large size. bandsome sbape and brigbt red color. Pkt. $10 \mathrm{c} .{ }_{1 / 2}^{1 / 2}$ Oz. $15 \mathrm{c}$ Oz. 30c.
Ozs. 55c. $1 / 4 \mathrm{Lb}$. 85c. $1 / 2$ Lb. $\$ 1.60$ Lb. $\$ 3.00$ Postpaid

302. Kelly Red, or Wade Tomato. It is large meaty, an abundant yielder and witbstands unfarorable conditions remarkably well. Pkts. $5 \mathrm{c}$ and $10 \mathrm{c}$. $1 /$ Oz. 20c. Oz. 30c. 2 Ozs. 55c. 1/4 Lb. \$1.00. 1/2 Lb. $\$ 1.90$. Lb. $\$ 3.50$. Postpaid.

288. King of the Earlies Tomato. Large and pro ductive. Very early. Pkts. 5c and 10c. $1 / 2 \mathrm{Oz} .20 \mathrm{c}$ Oz. 30c. 1/4 Lh. $\$ 1.00$. Lb. $\$ 3.50$

306. Bolgiano's New Queen Tomato. It is large, smootb and handsome, red color. For canning market purposes and sbipping it leads wberever grown. Lb. $\$ 1.60$. Lb. $\$ 3.00$

285. New Matchless Tomato. Yigorous, healtby vines are crowded ritb beautiful fruit of largest size and solidity. First-class shipper. Pkts. 5c and 10c. $1 / 20 \%$ 15c. Oz. 30c. 2 Ozs. 5.Jc. 1/t Lb. 85c. Lb. $\$ 3.00$ 524. Maul's Success Tomato. Large, red, main crop. Pkts. $5 \mathrm{c}$ and 10c. $1 / 3$ Oz. 15c. Oz. 30c. 2 Ozs. 1/ Lb. 85c I.b. $\$ 3.00$ Postpaid.

312. Llvingston's Paragon. Pkts. 5c and 10c. O\%. 30c. 1/4 Lh. 85e. Lb. $\$ 3.00$. Postpaid.

Livingston's Favorite. Pkts, 5c and $10 \mathrm{c} .0 \%$ 20c. $1 / 4$ Lb. 850 Lb. $\$ 3.00$. Postpaid

309. Perfertion. Pkts. $5 \mathrm{c}$ and 10c. 1/2 Oz. 15c.

30c. 2 Ozs. 55c. 1/4 Lb. 85c. 1/3 Lb. $\$ 1.60$ Lb. $\$ 3.00$

317. Ten Ton Tomito. Pkts. $5 \mathrm{c}$ and 10c. O\%. 80

1/4 Lb. 85c. Lb. $\$ 3.00$

WVEK EARLIER THAN EARLIANA. II ORE CHATE E THA. CHALK'S JEWWL
AS LARE AS THE GREAT B. B. AS SOLII AS THE NEW CENTURY LEADING EXTIREVHLY EARLY TOMATOES Price: Pkt. 5 \& 10c. Oz. 20c. Oz. 35e. 20zs. 65c. 1/4 Lb. \$1.15. 1/2 Lb. \$2.15. Lb. \$4.00. Postpaid

Bolgiano's I. $\mathbf{X}$. L. Tomato

301. Enormous Tomato. Largest, fruited, smooth. bright red Tomato. Pkts. 5c and 10c. $1 / 2$ Oz. $20 \mathrm{c} .0 \mathrm{Oz}$ t0c. 2 Ozs. 70c. $1 / 4$ Lb. $\$ 1.35$. $1 / 2$ Lb. $\$ 2.40$. Lb. $\$ 4.50$

502. Ponderosa. Tery large, hears, smooth To mato; rery fine for lome garden. Plits. $5 \mathrm{c}$ and $10 \mathrm{c}$ $1 / 2$ Oz. 25c. Oz. 50c. 1/4 Lb. $\$ 1.40$. Lb. $\$ 5.00$.

298. Brinton's Best, Pkts, Je and 10c. 1/2 Oz. 15c.

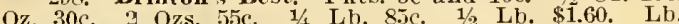
$\$ 3.00$. Postpaid.

2851/. World's Fair. Pkts, כe and 10c. Oz. 30c Lb. S5c. Lb. $\$ 3,00$. Postpaid.

\section{Pink Tomatoes}

187. Pink Giant-Bolgiano's New Tomato. Large, bandsome, solid fruit. Phts. 10c. 1/g O\%. 20c. Oz. $30 \mathrm{c}$ $1 / 4$ Lb. $\$ 1.00$. 1/2 Lb. $\$ 1.90$. Lb. $\$ 3.50$. Postraid,

282. Livingston's Beauty Tomato. Large, smooth, dark pinkisb red. thick flesh. Pkts. 5e and $10 \mathrm{c}$. Or. 30c. 1/4 Lb. $\$ 1.00$. Lb. $\$ 3.50$. Yostpaid.

268. June Pink Tomato. This is the Pink EarliPkts, 5c and 10c. 1/20z. 20c. Oz. 30c. Ozs. 55c. $1 / \pm$ Lb. $\$ 1.00$. Lh. $\$ 3.50$. Postpaid

369. Extra Selected Stock June Pink Tomato 10c. 1 Oz. 20c. Oz. 3uc. 2 Ozs. 65e. Lh. \$1.15. I/2 Lb. \$2.15. Lb. $\$ 4.00$

138. Burpee's Ear'iest Pink. A very early, prolific, attractive Tomato. Pkts. 5c and 10c. 1/2 Oz. $20 \mathrm{c}$ Oz. 30c. 2 Ozs. 56. $1 / 4$ Lb. $\$ 1.00$. Lb. $\$ 3.50$.

291. Improved Acme. Very early, of medium size perfectly smooth, very solid and a great bearer. Pkts. 202. Extra Early climax Tomato. Early, solid large size and a good bener. Pkts. Jc and 10c. 1 Oz. $20 \mathrm{c} .2$ Ozs. 55c. $1 / 4$ Lb. $\$ 1.00 .1 / 2$ Lb. $\$ 1.90$. Lb. $\$ 3.50$. fine flaror. Pkts. 5c and 10c. 1/2 Oz. 20c. $0 z .30 \mathrm{c}$ $1 / 4$ Lb. $\$ 1.00$. $1 / 2$ Lb. $\$ 1.90$. Lb. $\$ 3.50$.

218. Ear:s Detroit Tomato. Fruit very smooth. uniform in size, nearly globe shape. Pkt 10c. $1 / 3$ Oz. 20c. Oz. 30c. 2 Ozs. 55c. $1 / 4$ Lb. $\$ 1.00$ Lb. $\$ 3.50$ and prohablv one of the bet selections from Livings ton's Globe Tomato. Plit. 10c. 1/2 Oz. 20c. Oz. $30 \mathrm{c}$ $1 / 4$ Lb. $\$ 1.00$. Lb. $\$ 3.50$.

QS0. Folgiano's Prizetaker Tomato. If picker wbile jet green, it ripens cradually inio a rich, gloss crimson color, and this makes it one of the best ship pers for early market. Pkts. 5c aud 10c $1 / 20 z$ ? Oz. 30c. 2 Ozs. 55c. $1 / 4$ Lb. $\$ 1.00$. $1 / 2$ Lb. $\$ 1.90$. Lb. $\$ 3.50$ 289. Dwarf Chamoion. Dwarf. stiff babit, dart green foliage, scarcely needing any support, Pkts. 5c and $10 \mathrm{c} .1 / 2$ Oz. 15c. Oz. 30c. 2 Ozs. 55c. 1/4 Lb. $85 \mathrm{c}$ Lh. $\$ 1.60$. Lb. $\$ 3.00$.

281. Redfield Beauty. It is a vigorous gromer. long and heary rieider Pkts. 0 ac and $10 \mathrm{c} .50$ 


\section{${ }^{16}$ Bolgiano's Charleston or Large Wakefield Cabbage The Best Large Early Cabbage}

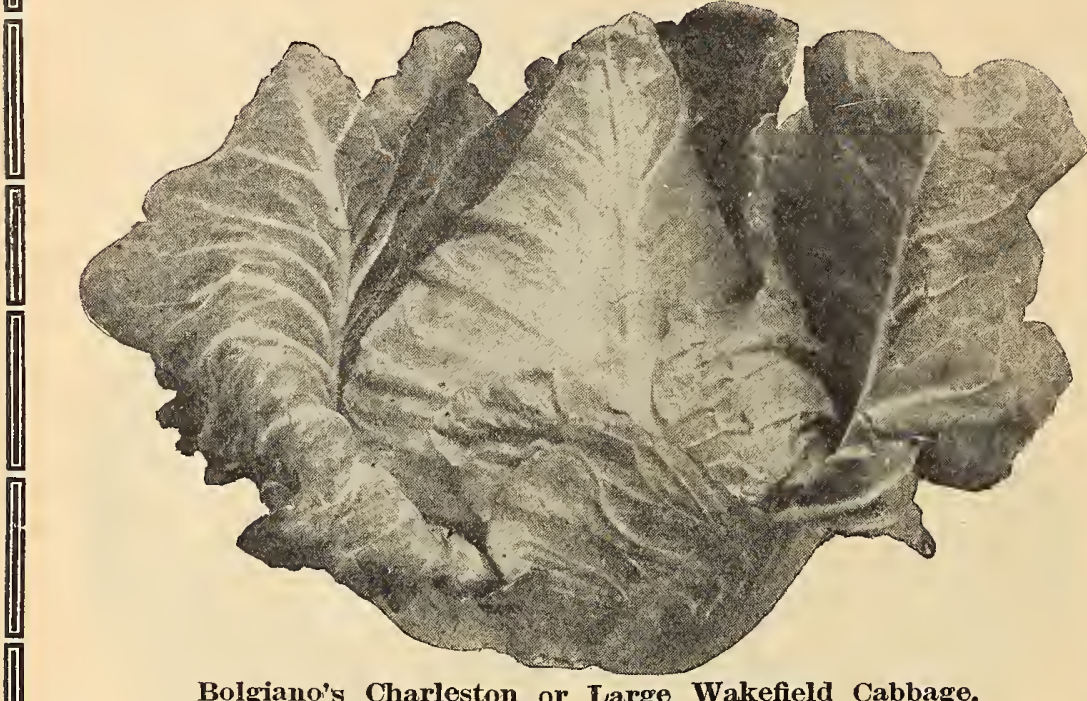

Bolgiano's Charleston or Large Wakefield Cabbage.

\section{BOLGIANO'S CHARLESTON OR LARGE}

WAKEFIELD CABBAGE The Best Large Early Cabbage.

Bolgiano's stock of this most wonderful cabbage has created a sensation with the cabbage growers all over the country, on account of the decided advantage it has over all other sorts. It can be the first variety sent to market, and on account of its handsome appearance will invariably bring the tiptop prices. If, however, the early market prices

are low, it can be safely left standing in the field to mature to an extra large, compact, solid, magnificent cabbage, which has never failed to attract the admiration of the most skilled gardeners, and always brings better prices than any other harvested at the same time. For sureness in heading and regularity in growth Bolgiano's Charleston or Large Wakefield Cabbage is the acme of perfection.

Prices-Pkg. 5c and 10c. 将 Oz. 20c. Oz. 30c. 2 Ozs. 55c. 1/z Lb. \$1.00. 1/2 Lb. $\$ 1.90$. Lb. \$3.50. Postpaid.

\section{Bolgiano's Selected “Ruby King” Pepper}

\section{The Finest Selected and Improved Stock}

\section{BOLGIANO'S SELECTED “RUBY} KING" PEPPER

This is the finest selected and improved stock of the well-known Ruby King Pepper. Most carefully selected for size and yielding qualities, and remarliable trueness to type and uniformity. We supply the Southern planters with thousands of pounds of our stock of Ruby King Pepper each year and it has become widely known for perfection of form, large size, brilliance of color, sweet and mild flavor. Plants grow two feet high and bear a fine crop of handsome, extra large, scarlet fruit. Our stock is exceptionaly thick meated, it is a heavy bearer and splendid shipper. The Peppers grow about 5 to 6 inches long and about 3 to 4 inches in diameter. The flesh is very thick, sweet and so mild it is often sliced for a salad, it is also fine for stuffing. If you want some of the finest stock of Ruby King Pepper in the world place your order with us at once.

Pkg. 5c and 10c. Oz. 35c. 将 Lb. \$1.15. Lb. \$4.00. Postpaid.

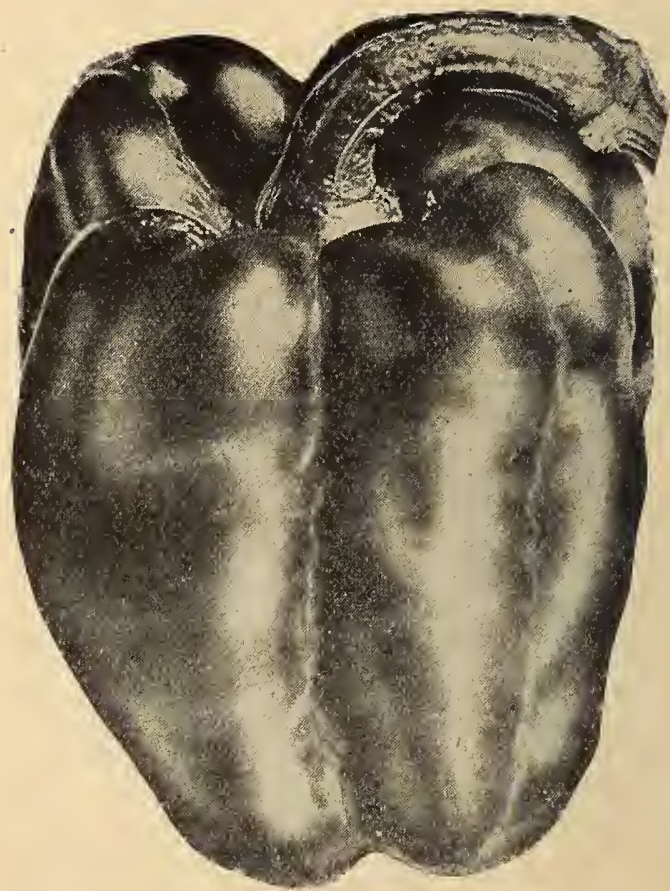

Bolgiano's Selected Puloy IKing Pepper. 


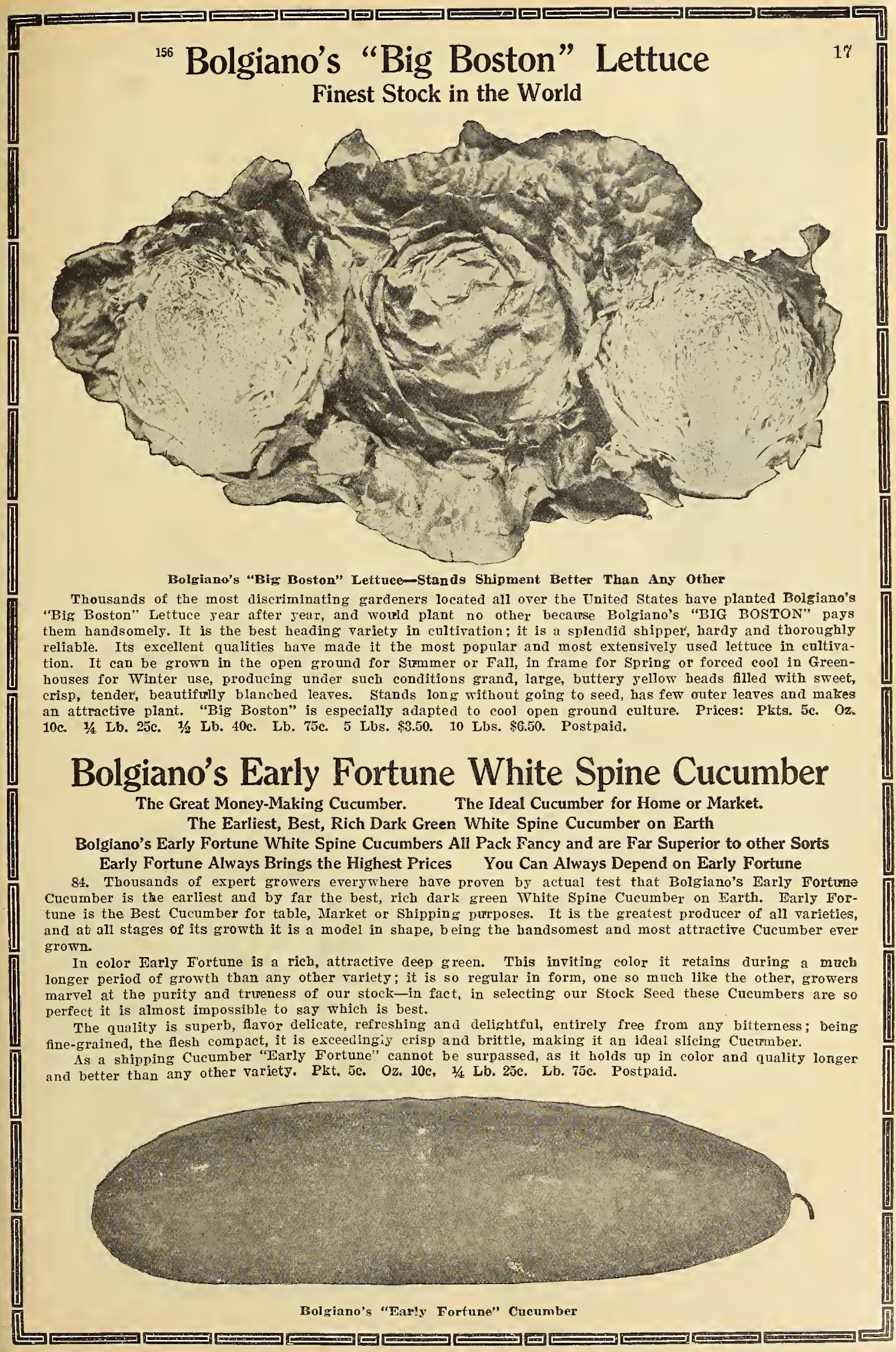




\section{Bolgiano's “Big Crop” Vegetable Seeds for Fall Planting}

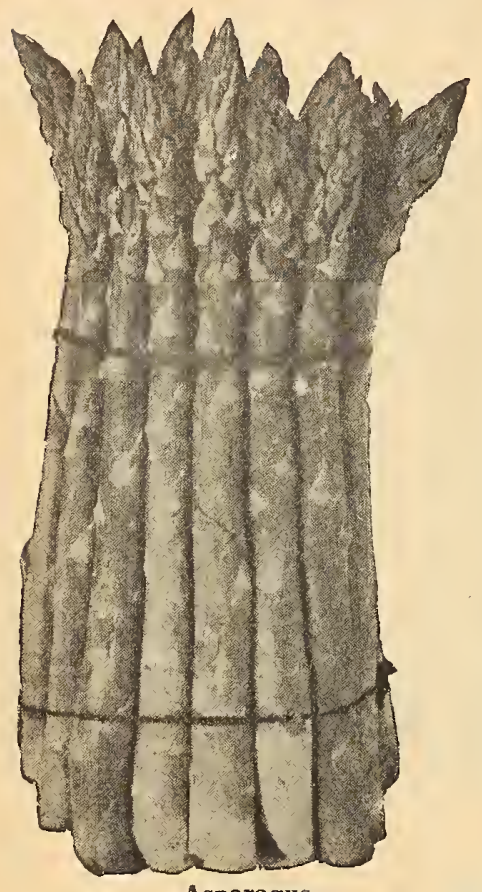

Asparagus

\section{Asparagus Seed}

1. New Palmetto. Is very early, large yielder, and very regular and even in growth. Average buncbes contain 15 sboots, measuring $131 / 2$ inches in circumference; weighs 2 pounds. It is equally well adapted for all sections. Its quality is unequaled. Pkt. 5c. Oz. 10c. 1/4 Lb. 20c. Lb. 50c. $5 \mathrm{c}$. Oz. 10c. 1/4 Lb. 20c. Lb. $50 \mathrm{c}$

526. Columbian Mammoth White. Pkt. 5c. Oz. 10c. 1/1 Lb. 20c. Lb. 50c.
582. Barr's Mammoth. Pkt. 5c. Oz. 10c. 1/4 Lb. 20c. Lb. 50c. We suppiy Packets of all Beans Green Pod Bush Beans
at 5c and $10 \mathrm{c}$ each. ALL CROICEST MARKET GARDENER'S STOCKS

Parcel Post Rates, see Page 2. We Pay Postage on $5 \mathrm{c}$ and $10 \mathrm{c}$ Pkts. Seed Beans Weigh by Parcel Post: Pints 2 lbs. Qts. 3 lbs. 4 Qts. 9 lbs. Pk. 17 lbs. 1 Qt. to 100 feet of drill two bushels to the acre.

Culture. Beans are somewhat tender, but it often pays to take some risk. Plant in warm, loamy soil at the beginning of settled, warm weatber in Spring, and at intervals for succession until Auguist. Rows may be made 2 feet apart, and the Beans planted not more than 2 incbes deep and sereral incbes apart in the drills, or 3 or 4 Beans in bills 6 to 8 incbes apart. Cultivate and boe frequently, always, however, when the vines are perfectly dry. In boeing draw the soil up towards tbe rows of plants. For String Beans gather the pods clean as fit for use. The plants will remain all tbe longer in bearing.

1013. Black Valentine Beans. Matures early, producing long, round, straight, tender pods of bligbt-resisting qualities. Pkt. 10c. Pt. 25c. Qt. 40c. 2 Qts. 75c. 4 Qts. $\$ 1.40$. Pk. $\$ 2.50$. Bu. $\$ 9.50$.

1002. New Emerald Beauty Bean. The Emerald Beauty is a flat, green podded, Busb Bean, a prolific and continuous bearer, the first in Spring and the last in Fall. It is absolutely stringless, very tender and delicious flavor. The plant is of remarkably bandsome and thrifty growth. The rich, green pods are of immense size thick, broad, extra long; uniform shape, solid, meaty and of bigh quality. Market that will accept a flat podded bean will soon appreciate the quality. Market that will acceld Beauty. Pkt. 10c. 1/2 Pt. 15c. Pt. 25c. Qt. 40c. 2 Qts. 75e. 4 Qts. $\$ 1.40$. Pk. $\$ 2.50$. Bu. $\$ 10.00$

\section{Bolgiano's "Mighty-Nice" Bean}

1033. This wonderful, new, round, meaty, green-podded Bean had for its parents two separate and distinct stocks of thoroughbred Hopkins' Improved Earliest Red Valentine Beans, and in tbe breeding of these two stocks we bave produced an extremely Early and most prodigiously productive stock of beautiful deep-green, round-podded Valentine Beans. The flavor and quality cooked and tested side b. side witb 50 other leading varieties prored the Bolgiano's "Mighty-Nice" Bean to be by far the most delicious and
tender. Pkt. 10c. Pt. 25c. Qt. 40c. 2 Qts. 75c.4 Qts. $\$ 1.40$. Pk. $\$ 2.50$. Bur. $\$ 10.00$.

Bolgiano's New "Home Sweet Home" Beans

1134 A most delicious Bean for the bome garden, very productive, large, long, handsome flat pods, full of big. rich, tender, sweet Beans. The Beans when dried make the finest kind of Winter drier Beans and wben baked will fairly melt in your mouth. If you once try tbe Home, Sweet Home Beans you will always bave it in your kitchen garden. Market gardeners will also find this a very lucrative Bean to sell to fancy market or grocery store trade Pkt. 10c. 1/2 Pt. 15e. Pt. 25 .

1.40. Pk. $\$ 2.50$. Bu. $\$ 10.00$. great improvement on tbe oldtime popular favorite Valentire Bean. Tbe pods are fully one-third longer, averaging 5 to 6 inches in length; absolutely stringless, very crisp, round, full and fleshy, its bandsome pods being ready for market a few days earlier than old Valentine. An exceptionally profitable Bean to grow for canners, as tbey are in murch demand with the Canning Trade. Pkts, 10c. 1/2 Pt. 15c. Pt. 25c. Qt. 40c. 2 Qts. 75c. 1009. Burpee's New Stringless Green Pod Beans. Crisp, tender, luseious flavor. Handsome light green, round pods; are ready to market TWO WELKS EARL produced in great abundance. Will remain green on vines in an edible condition longer tban any other bean known. Pkts. 10c 1/ Pt. 15c. Pt. 25c. Qt. 40c. 2 Qts. 75c $4 \mathrm{Qts}, \$ 1.35$. $\$ 2$. 50 Bu $\$ 9.50$

1003. Extra Early Refuge Round Green Pod. Has pods of a beautifur, attractive light green color, round, tender and of a luscious flavor. Exceptionally heary bearers. Pkt. 10c. Pt. 25c.

1006. Hopkins' Earliest Red Valentine Beans. Ar one of the earliest and most prolific round green podded Beans. Comes into bearing earlier than the old stock of Valentines, is a wonderful producer and a perfect sbipper. Pkt. 10c. Pt. 25c. Qt. 40c. 2 Qts. 75c. 4 Qts. $\$ 1.35$. Pk. $\$ 2.50$. Bu. $\$ 9.50$.

1007. Bolgiano's Earliest Red Valentine Beans. This superior Bean bas been carefully built up to satisfy a most critical market gardener's trade. Under favorable conditions it is ready for picking in 35 days from planting. Pkt. 10c.Pt. 25c. Qt. 40c. 2 Qts. 75c. 4 Qts $\$ 1.35$. Pk. $\$ 2.50 . \mathrm{Bu}, \$ 9.50$

1001. Late Refuges or 1,000 to 1 . Exceedingly productive; for medium and late use. The young pods are tender and of fine flaror, the color is a silver green. 政, An extremely profitable bean Qt. 40c. 2 Qts. 75c. 4 Qts. $\$ 1.35$. Pk. $\$ 2.50$. Bu. $\$ 9.50$. 1010. Dwarf Horticultural or Cherry Bean. A cror of these Beans bas never failed to pay. This is a broad. long, flat, meaty, Stringless Bean, very productive, delicious flavor. It also makes a good dried Bean for Win

\section{Bolgiano's Hardy “May Queen” Beans}

\section{Extremely Early-The Long "Rat Tail" Bean}

1001. It is remarkably early, exceedingly prolific and its extra large finely shaped, straicht, dark-green pods are always solid, tender and of a delicious flavor and borne in great abundance. It is a most excellent sbipping Bean. carrying in fine shape for many days after it is picked. Some of our customers have also tried it as a late Bean, with astonishing results. The stock is perfect, the plants are of a strong, robust habit and mature the crop very regularly. Pkt. 10c. 1/2 Pt. 15c. Pt. 25c. Qt. 40c. 2

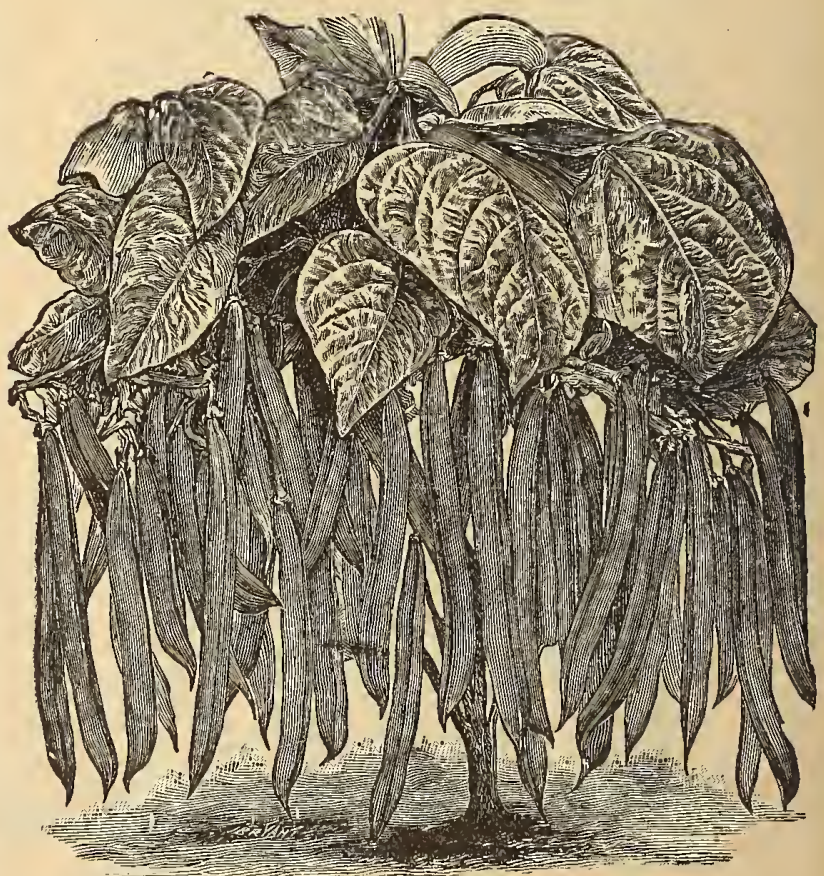

Iopkins' Earliest Red Round Green Pod Valentine Beans 


\section{Green Pod Bush Beans, con't}

1217. Low's Champion Bush Beans. Large, long, tender, stringless pods, delicious. This Bean in the last few years has hecome extremely popular with the Market Gardeners' Pk. \$2.50. Bu. $\$ 10.00$.

1011. Henderson's Bountiful Beans. A prolific and continuous hearer. The first in Spring, the last in Fall. Stringless, delicious flavor. Used rery extensively around the Norfolk Section. Pkt. 10c. Pt.

1017. Extra Idong Yellow, Six Weeks. Pods flat and green; a leading market sort. Pkt. 10c. Pt. 25c. Qt. 40c. 2 Qts. 75c. 4 Qts. $\$ 1.35$. Pk. $\$ 2.50$. Bu. $\$ 9.50 .10$ Pt. 25c. 1184. White Navy or Pea Beans, Pkt. $10 \mathrm{c} . \mathrm{Pt}$. 25c.
t. 40c. 2 Qts. $75 \mathrm{c}$. 4 Qts. $\$ 1.30$. Pk. $\$ 2.25$. Bu, $\$ 7.00$.

1015. Longfellow Green Podded Bush Beans, Long, round, green pods, exceedingly prolific, always solid. Remarkahly early. Pkt. 10c. Pt. 25e. Qt. 40e. 2 Qts. $75 \mathrm{c}$ Pl $\$ 250$ Bu, $\$ 9.50$.

1281. King of the Caries: Pods long, smooth, straight and of a haudsome bright green color. Very prolific. Excellent Shipler. Pkt. 10c. Pt. 25c. Qt. 40c. 2 Qts. 75c. 4 Qts. $\$ 1.35$. Pk. $\$ 2.50$. Bu. $\$ 9.50$.

1282. Best of Ail Early Harket. Vigorows hranching hahit. Pods 5 to $51 / 2$ inches long. A heavy producer. Pkt. 10c. $P$ t.

503. Broad Windsor Beans. The largest and best. Pkt. 10c. $1 / 2$ Pt. 15c. Pt. 30c. Qt. 50c. 2 Qts. 95e. 1 Qts. $\$ 1.75$

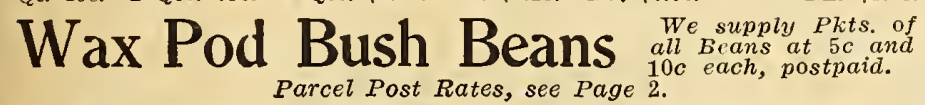

1031. New Peari Wax Beans. A distinct, enormously prolific and prodigious growing Bush Wax Bean. Every grower should try it. A very popular and lucrative variety to grow. Will not rust in the wettest kind of weather. Pkt. 10c. $1 / 2$ Pt.
$t$ Qts. $\$ 1.65$. Pk. $\$ 3.00$. Bu. $\$ 11.00$.

1183. "Truckers" Reward," Bolgiano's New Flat Wax Bean. One of the most raluahle and important Bean introductions in many years. Unequaled as an cnormous, heautiful crop producel and money maker. Pkt. 10c. $1 / 2$ Pt. 20c. Pt. 30c. Qt. 50c. 2 Qts. 95c. 4 Qts. \$1.65. Pk. $\$ 3.00$. Bu. $\$ 11.00$.

1079. New Hodson Wax Beans. A very sturdy grower, prolific; free from rust and blight. Vigorous plants are loaded with long, handsome, straight pods, averaging 7 inches in length; color of a clean, light yellow. When picked young they are stringless. Very popular in Extreme South, When picked yourng they are stringless. Very popular in Extreme South,
also around Norfolk Section. Pkt. 10c. Pt. 25c. Qt. 40c. 2 Qts. 75c. 4 also around Norfolk Section. Pkt.
Qts. $\$ 1.40$. Pk. $\$ 2.50$. Bu, $\$ 10.00$.

1021. Round Podded Kidney Wax Beans. (Brittle Wax.) This handsome wax-podded Bean is an improved Wardwell's Kidney Wax, hesides haring that popular variety's luxuriant growth, it is entirely striugless. The pods are long, straight and extremely handsome. It is an exceedingly heavy hearer, and is fully as early in maturing as the Wardwell's Kidney Wax, and is of excellent quality. Pkt. $10 \mathrm{c}$. 1/2 Pt. 25c. Pt. 35c. Qt. 65c. 2 Qts. $\$ 1.20$. 4 Qts. $\$ 2.10$ Pk. $\$ 3.75$. Bu. $\$ 14.50$. 1024 New California Rust-Proof Dwarf Wax. One of the handsomest and most productive flat podded Wax Beans ever grown. The rines are of vigorous growth, leaves dark green, hardy and yield enormous quantities of large, handsome, flat, meaty pods. Plit. 10c, $1 / 2$ Pt.
15c. Pt. 25c. Qt. 40c. 2 Qts. 75c. 4 Qts. $\$ 1.40$. Pk. $\$ 2.50$ Bu. $\$ 10.00$. Pt. 25c. Qt. 40c. 2 Qts. 75c. 4 Qts. $\$ 1.40$. Pk. $\$ 2.50$, Bu. $\$ 10.00$.
1019 . Currie's Improved Rust-Proof Wax Beans, The kind that will not spot. Is the earliest to mature of either the Green or Wax Beans. It is ready for market in 25 days from date of planting. Its heautiful, pure golden, long, flat pods of extra fine quality are horne in ahundance and attract the admiration of hoth the planter and the consumer. Entirely fre from rust and blight. Pkts. 5c and 10c. Pt, 25c. Qt. 40c. 2 Qts. 75c. 4 Qts. $\$ 1.35$. Pk. $\$ 2.50$. Bu. $\$ 9.50$.

1022. New Davis Kidney Wax. The King of Flat Wax Beans, A heautiful form, handsome long pods, attractire color, luscious flavor, prolific yielder, rust-proof, excellent shipper. Pkts. 5c and 10c. Pt. 25c. Qt. 40c. 2 Qts. 75c. 4 Qts. $\$ 1.40$. Pk. $\$ 2.50$. Bu. $\$ 10.00$.

1020. Wardwel's Kidney Wax. Early, long, flat, pure wax pods. It is hardy, both pods and plants are rohust and healthy, and it is a heavy vielder. It is a remarkahle shipper. Pkt, 10c. Pt. 25c. Qt. 50c. 2 Qts. 95c. 4 ots. $\$ 1.75$. Pk. $\$ 3.10$ Bu. $\$ 12.00$.

1096. Prolific Dwarf Black Wax. One of the earliest. Pods 4 to 5 inches in length, uswally curved, quite round, meat, hrittle and stringless; deep golden, 5 ellow of excellent flaror. Pkt. 10c. 1/2 Pt. 15c. Pt. 25c. Qt. 40c. 2 Qts. 75c. 4 Qts. \$1.35. Pk. \$2.50. Bu. \$9.50.

1219. Pencil Pod Black Wax Beans. Plants of true hush growth, 15 inches high, extremely productive; magnificent straight pods 6 to 7 inches long, light golden yellow in color, heautifully rournd, meaty and deeply saddle-backed; flesh hrittle, solid and entirely stringless; fine and mild flavor. Pkt. 10c. 1/ Pt. 15c. Pt. 25c. Qt. 40c. 2 Qts. $75 \mathrm{c}$. Qts. $\$ 1.40$. Pk. $\$ 2.50$. Bu. $\$ 10.00$.

1026. Keeney's Rustless Golden Wax. Early, vigorous and a bountifill vielder of beautiful tender pods. The vine grows $11 / 2$ feet high, holding the pods well off the ground. The pods are shapely, flat and large. $1 / 2$ Pt. 15c. Pt. 25c. Qt. 40c. 2 Qts. 75c. 4 Qts. $\$ 1.40$. Pk. $\$ 2.50$. Bu. $\$ 10.00$ 1283. Britte Wax. Pods round, tender, stringless. Very prolific.

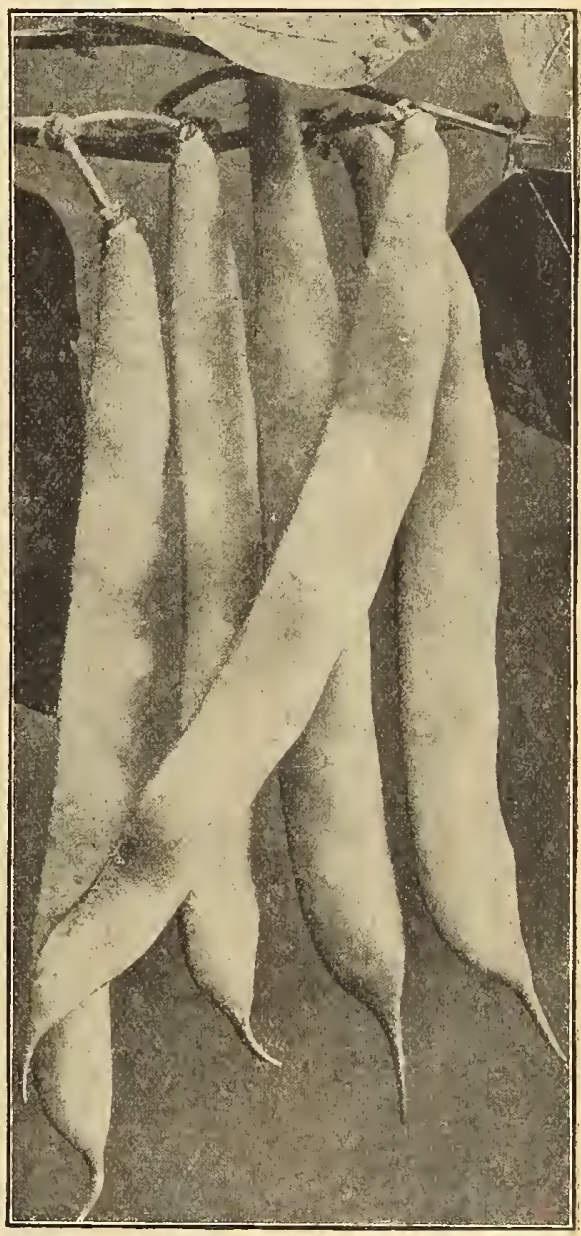

Bolgiano's New Pearl Wax Beans

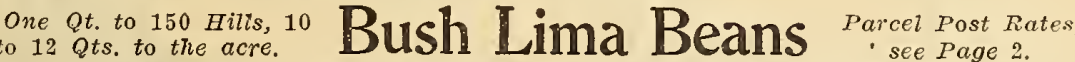 \\ We supply Packets of Lima Beans at $5 c$ and $10 \mathrm{c}$ each, postpaid.}

Culture. Selected land that is especially trarm, rich and well supplied with vegetahle fihre or humus. Plant as soon as the soil has become warm in Spring. Make the row' 2 feet apart and give to each plant 6 inches space in
the row. A top dressing of poultry manure, ashes or some the row. A top

good fertilizer. This wonderful new Lima is the earliest, largest and hest of all Bush Lima Beans. Most productive. The vigorous hushes are crowded with enormous pods. Pkt. 10c. 1/ Pt. 25c. Pt. 10c. Qt. 75c. 4 Qts, $\$ 2.35$ Pk. \$ 55 Bu. $\$ 16.00$.

1119. Fordhook Bush Lima New. Both pods and Beans are twice the size of Dreer Bush Lima. An abundant prodicer of large, thick, heary heans. Plit. $10 \mathrm{c}$. Pt. $15 \mathrm{c}$. Qt. T5. 2 Qts. $\$ 1.35$. 4 Qts. $\$ 2.50$. Pk. $\$ 4.50$. Bu. $\$ 18.00$

1034. Wond's Prolifie Bush Lima. An "Improfed Hen derson Bush Lima." Earlier than the Burpee's Bush Lima, hut somewhat smaller in size of Beans. Making a larger growth than others; stems are loaded down with Beans in great clusters. Pkt. 10c. Pt. 25c. Qt. 40c. 2 Qts. 75c. $1 \mathrm{Q}^{2}$ s. $\$ 1.30$. Pk. $\$ 2 . \pm 0$. Bu. $\$ 9.00$.
1058. Burpee- "Improved" Bush Lima, Pods and Beans are extremely large. Plant grows more erect than Burpee's

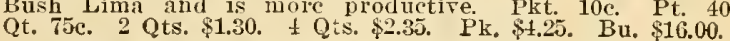
1036. Dreer's New W'onder Bush I.ima Beans It is a fine strain of neat dwarf growth, producing pods a week earlier than the regular stock of Burpee's Bush Lima. The plants are productire, the pods and brans ale large. Very popular in the home garden. Pkt. 10c. Pt. 20c. Qt. 60c. 1039. Burpee's "Large" Bush Lina Beans. Is an immellse fielder, each hush bearing from 50 to 200 of the handsome, large pods, well filled with very large heans, which are irlentical in size and luscious flaror to the werlknown large Pole Timas. Pkt. $10 \mathrm{c}$ Pt. $35 \mathrm{c}$
Qts. $\$ 1.20 .+\mathrm{Qts} . \$ 2.10$. Pk. $\$ 3.75$. Bu. $\$ 14.50$

103S. Henderson's Dwarf Bush Lima Beans. Producing Beans of a smaller size, is very productive and decidedly delicious. Pt. 25c. Qt. 40c. 2 Qts. 75c. 4 Qts. \$1.30.
Pk. \$2.40. Bu. \$9.0?. 


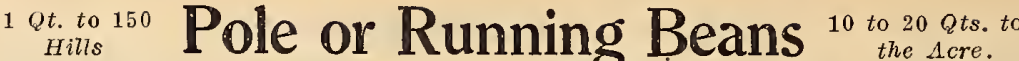

1027. Lazy Wife or White Pole Cherry Beans. The pods of medium, dark green color, are produced in great abundance and measure $4 \frac{1}{2}$ to 6 inches in length; a re broad, thick, very fleshy and entirely stringless. They retain their rich, tender and stringless qualities until nearly ripe. Each pod contains 6 to 8 round white beans, which make
excellent Winter Shell Beans. Pkt. 10c. Pt. 35c. Qt. 70c. 2 Qts. $\$ 1.25$. 4 Qts. $\$ 2.25$. Pk. $\$ 1.00$. Bu. $\$ 15.00$.

1025. Point Market Prolific Pole Beans. A very productive and delicious stringless Pole Bean. Pkt. 10c. Pt. 30c. Qt. 50c. 2 Qts. 95 c. 4 Qts. $\$ 1.75$. Pk. $\$ 3.25$. Bu. $\$ 12.00$. 1258. Red Speckled, cut Short, or Corn Hill. An old variety, very popular for planting among Corn and will give a good crop without poles. Vines medium, not twin30c. Qt. 50c. 2 Qts. 95c. 4 Qts. $\$ 1.70$. Pk. $\$ 3.15$. Bu. $\$ 11.50$.

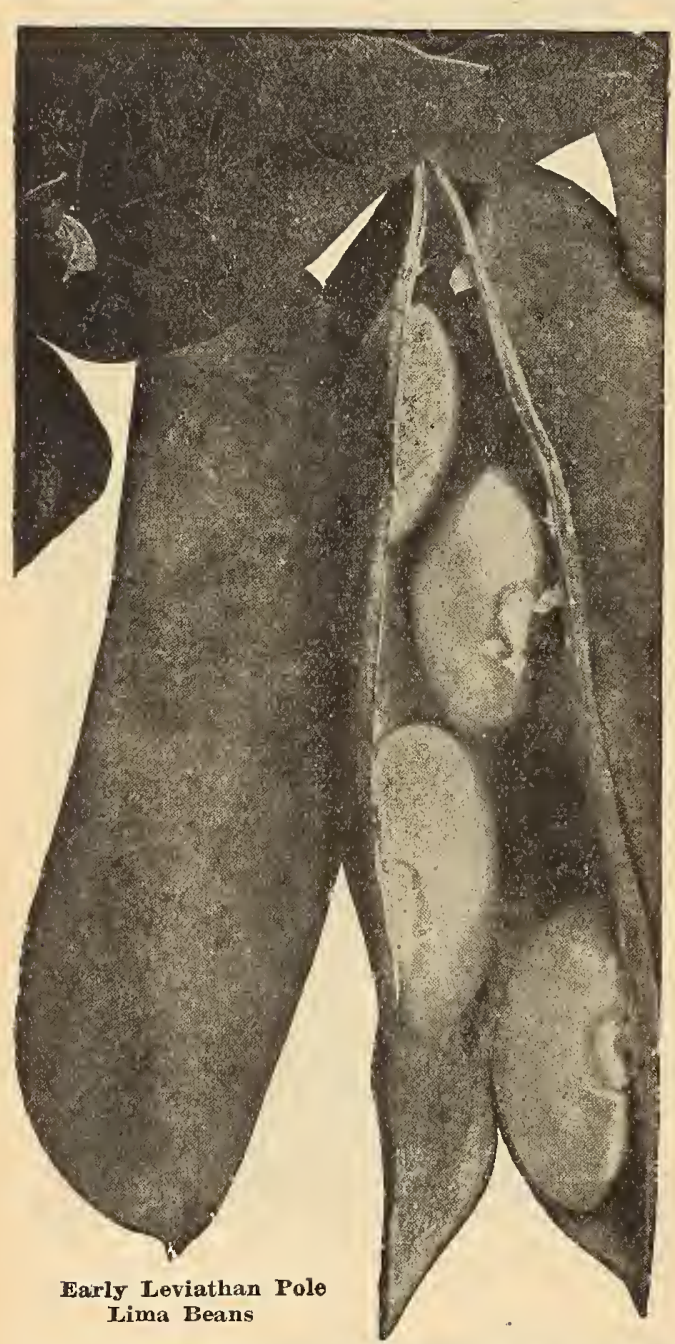

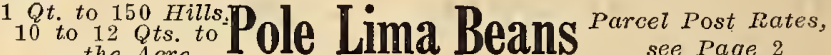
the Acre 1010 Hilla Healls

We supply Paakets of Beans at $5 c$ and $10 c$ each, postpaid

1032. Giant Emeraid Isie, Bolgiano's New Pole Lima Pean. This wonderful Bean is the largest podded, and the heaviest cropper of all Limas. It grows green, dries green, stays green. Pkt. 10c. Pt. 25c. Qt. 40c. 4 Qts. \$1.40. Pk. \$2.50. Bu. \$10.00,

1010. Early Leviathan Pole Lima Bean. This sort is at least one week earlier than any large Pole Lima yet offered and fully two weeks earlier than most. Pkt. 10c. Pt. 25c. Qt. 40c. 4 Qts. $\$ 1.40$. Pk. $\$ 2.50$. Bu. $\$ 10.00$

1041. Dreer's Improved Pole or Chal'engex Lima. Outyield any Lima Bean ever offcred. Each pod contains from 2 to 6 delicious Beans, so compactly placed that they make indentations in each other. Pods are produced on the vines in great clusters. Pt. 25c. Qt. 40c. 4 Qts. $\$ 1.40$. Pk. $\$ 2.50$. Bu. $\$ 10.00$.

1223. Henderson's ideal Pole Limas. Yery early, wonderfully productive. Pt. 25c. Qt. 40c. 4 Qts. $\$ 1.40$. Pk. $\$ 2.50 . \quad$ Bu. $\$ 10.00$.

1042. Seibert's Early Lima. Pods long, thin and easily opened. The green Beans are very large; hand some and delicious quality. Pt. 25c. Qt. $40 \mathrm{c}$. 4 Qts. $\$ 1.35$. Pk. $\$ 2.50$. Bir. $\$ 9.50$.

1043. Jersey Extra Early Lima. Is 10 dass to 2 weeks earlier than any other Pole Lima, except the Leviathan. The beans are exceptionally tender and delicious. Pt. 25c. Qt. 10c. 4 Qts. $\$ 1.40$. Pk. \$2.50. Bu. \$10.00.

1044. Carolina or Sieva Beans. Very early and productive. Pt. 25c. Qt. 40c. 4 Qts. $\$ 1.25$. Pk. $\$ 2.50$. Bu. $\$ 9.50$.

1046. Ford's Mammoth Extra Large Lima Beans. Its pods are large in size, containing from 3 to 8 Beans. Pt. $25 \mathrm{c}$. Qt. $40 \mathrm{c}$ 4 Qts. $\$ 1.40$. Pk. $\$ 2.50$. Bu. $\$ 10.00$.

1047. King of Garden Lima Beans. Outrivals all other Pole Limas. Its rine has a luxurious growth, which abounds with enormous pods, often 5 to 8 inches long, and filled with 5 to 6 perfect Beans to a pod. Pt. 25c. Qt. 40c. 4 Qts. \$1.35. Pk. \$2.50. Bu. $\$ 9.50$.

1224. Carpenteria Pole Limas. One of the longest podded and heaviest croppers of all Limas. Pkt. 10c. Pt. 25c. Qt. 40c. 4 Qts. $\$ 1.40$. Pk. $\$ 2.50$. Bu. $\$ 10.00$

1045. Extra Large Lima. Large white Bean; very tender, equally good in Winter if soaked 10 hours before cooking. Pt. 25c. Qt. 40c. 4 Qts. $\$ 1.40$. Pk. $\$ 2.50$. Br. $\$ 10.00$.

\section{Pkts., Ozs, and 1/4 Lbs Belivered Free
Deli Parcel Post Rates,}

In lots of 5 lbs. each at 5e per Ib. less.

Culture. Fibrous loam, well drained and well enriched, will raise good Beet Crop. For early table Beets have drills 16 to 20 inches apart, and sow the seed about 1 inch deep, as early as the ground can be put in good shape, or seed may be sown ander glass four weeks sooner, and the young seedlings transplanted to open ground, to give an extra early crop. Give thorough and clean cultivation, and thin the plants to stand 3 to 4 inches a part clean cultivation, and thin the plants to stand 3 to 4 inches apart For earliest sowings a light dressing of nitrate of soda, say 100 pounds per acre, will sometimes work wonders.
377. Bolgiano's New Early Spring Beet. First Beet in market. Most perfect shape and color. Earlier maturing than Crosby's Egyptian and of a much finer grain. Has very small tap root and small top. All coming into maturity at same time. Well adapted for forcing. Pkt. $10 \mathrm{c}$. Oz. 15c. 2 Ozs. 25e. 1/1/4 Lb. 45c. 1/2 Lb. 80c. Lb. \$1.50. Postpaid.

295. “Bonfire," Bolgiano's New Early Beet. A splendid new variety specially adapted for market gardeners, being suited for forcing under glass and for open ground culture For home garden this Beet will be found desirable, as it retains its freshness and high quality without becoming tough. Pkt. 10c. Oz. 15c. 2 Ozs. $25 \mathrm{c}$. 1/4 Lb. 30c. 1/2 Lb. 55c. Lb. \$1.00. Postpaid.

18. Bolgiano's Deep Blood Beauty Beet. The most popular market gardener's' Beet ever introduced. Pkts. 5c and 10c. Oz. 15c. 1/4 Lb. 30c. $1 / 2$ Lb. 55c. Lb. $\$ 1.00$. Postpaid.

12. American Beauty Beet. The skin and flesh of "American Beanty" Beet are both a deep rich blood crimson color. It matures just after the Eetipse has a deep rich blood crimson color. It matues than round, medium in size, generally about three inches in diameter, has a remarkable medium in size, generally about three inches in diameter, has a remarkable

115. Early Model Beet. This is a fine selection of blood red Beet, extremely smooth and of symmetrical growth, rich color and desirable shape. It makes a rapid growth and matures very early. The shape is nearly round, and color of flesh blood red. Pkts. $5 \mathrm{c}$ and 10c. Oz. 10c. 1/4 Lb. 25c. Lb. $75 \mathrm{c}$.

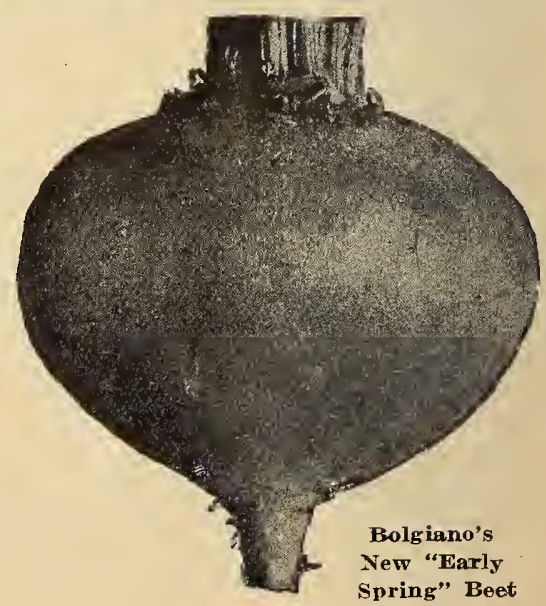


Beets, continued

In Lots of 5 Lbs. or More at $5 c$ Per Lb. Less.

3. Early ox-Blood. 6 Reasons Why We Introduce This New Beet. 1. It is extra dark blood color from end of its tap root to top of its short, graceful leaves. 2. Early as the Crosby togyptian. 3. Almost globe shape. 4. Small amount from side rootlets. 6. Flesh fine grained, sweet and of oxsmooth and free from side roc. Oz. 10c. 1/4 Lb. $25 \mathrm{c}$. Lb. $75 \mathrm{c}$.

4. Extra Early Eelipse. Remarkable for its very rapid growth, the perfection of its form-which is globular-of its beautiful crimson flesh, and for its dwarf foliage. Roots are bright glossy red. Pkts. 5c and 10c. Oz. 10c. 2 Ozs. 15c. 1/4 Lb. $20 \mathrm{c}$, Lb. 60c.

5. Crosby's Improved Extra Early Egyptian Beet. An improvement on Extra Earl, Egyptian, being as early, but of mole desirable shape, color and qurality. It is very sweet and tender; a most valuable sort por early market, as it is ready before any other
and 10c. Oz. 10c. $1 / 4$ Lb. 20c. Lb. 60c.

6. "Now Crimson Globe Beet. This is one of the best Bunching Beets yet introduced. A handsome variety of medium size, almost globe shape, roots are of medium size. Beets average 10 inches in circumference. Very handsome in shape, being a little deeper than round, with a remarkably smooth surface. The foliage is small and of a rich bronze purple, borne smonsen stems which occupy but a small portion of the root. Flesh is on slender stems which occupy but a small portion of the root. Flesh is a rich blood red, slightly zoned or ringed in a most beautifu manner, Oz. 10c. 1/4 Lb. 20c. Lb. 65c.

7. Detroit Dark Red Beet. A splendid Beet of a dark red color, for home or market. By far the best for canning, on account of its beauty. and darker bands; tender and sweet. Pkts, $5 \mathrm{c}$ and $10 \mathrm{c}, \mathrm{Oz}, 10 \mathrm{c}, 1 / 4 \mathrm{Lb}, 20 \mathrm{c}$.

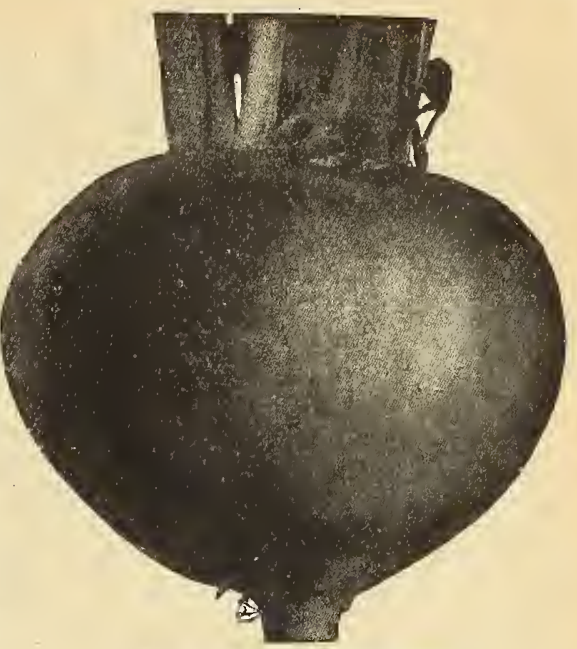

Extra Early Eclispe Beet and Lb. $35 \mathrm{c}$. Lb. $65 \mathrm{c}$

11. Extra Early Dark Red Flat Egyptian Beet. The Egyptian Beet is one of the most popular varieties among it is considered to be the earliest of all. It certainly will bear close planting in the valuable space under glass or in warm garden in early Spring. It is turnip-shaped, and when young is crisp and tender. In color it is dark red. when young is crisp and tender. In color it. $20 \mathrm{c}$. $1 / 2 \mathrm{Lb}$. Pkts. $5 \mathrm{c}$ and 1

35c. Lb. 65c. 20 . Early Blood Turnip Beet, New Improved. It is early, smooth, does not grow overlarge, has few roots. It does not become stringy, matures a medium size, deep Oz. 10c. 2 Oz. 15c. 1/4 Lb. 20c. Lb. 50c.

21. Edmand's Blood Turnip Beet. A handsome, clean, turnip-shaped blood Beet. Skin and flesh are of a deep blood red, sweet and tender in quality and unsurpassed for solidity and keeping purposes. The roots grow regular for solidity and keeping purposes. The roots grow regular and are of right marketable size. Topsts. 5c nd 10c. Oz. 10c. $1 / 4$ Lb. 20c. Lb. $50 \mathrm{c}$.

10. Early Large Egyptian. None better for an early general crop than the early Egyptian; handsome shape and does not crack open. This crop commands a good 20c. $1 / 2$ Lb. $30 \mathrm{c}$. Lb. 50c.

${ }_{13}^{1 / 2}$ Lentz. 30xtra Early Beet. Color a deep, blood red, tender and sweet at all stages of its growth. Has small top and can be used six weeks from scwing. Very productive, a splendid keeper and shipper. Pkts. 5c and 10c. Oz. 10c. 2 OzS. 15c. 1/1 Lb. $25 \mathrm{c}$. $1 / 2 \mathrm{Lb}$. $45 \mathrm{c}$. Lb. 85c.

358. Nutting's Early Gem Beet. Extremeiy early, light colored top, flesh beautifully zoned light red. Very popu 2 Ozs. 15c. 3/4 Lb. $25 \mathrm{c}$. 1/2 Lb. 40c. Lb, $75 \mathrm{c}$.

426. New Royal Red Beet. Choice Market Gardeners sort. Pkts. 5c and 10c. Oz. 10c. 1/4 Lb. $25 \mathrm{c}$. 1/2 Lb. $45 \mathrm{c}$. Lb.

533. Bassano Extra Early Flat. A very early, tender colors, regularly arranged. Pkts. 5c and 10c. Oz, 10c. 1/4 Lb. 20c. Lb. $60 \mathrm{c}$

336. Bastian's Extra Early Beet. An early, large-sized, turnip-shaped Beet of the brightest red color, beautifully zoned with rings of lighter color. Pkts. 5c and 10c. Oz. 10c. $1 / 4$ Lb. 20c. 1/2 Lb. 35c. Lb. 60c.

35. Burpee's Black Red Ball Leaf Beet. Extremely dark red in color of both foliage and flesh, deliciously $1 / 2$ Lb. 35c. Lb. $65 \mathrm{c}$.

514. Dewing Blood Turnip. Early, large, fine turnip form and bright red color, zoned with lighter rings. Profitable for market or home garden. An old favorite Pkts. $5 c$ and 10c. Oz. 10c. $1 / 4$ Lb. 20c. 1\% Lb. 35c. Lb. $60 \mathrm{c}$

571. Half Long Dark Blood. This is rapidly becoming a very popular sort and will probably produce more bushels from a given area than any other sort, as it does not occupy so much space in the rows as the turnip-shaped varieties. Pkts. 5c and 10c. Oz. 10c. 1/4 Lb. 20c. Lb. 65c. blood-red roots, going well down into the soil, enabling it blood-red roots, going well down into the soil, enabling it. to resist drought and heat. Flesh very tender and sweet.
Pkts. 5c and 10c. Oz. 10c. 1/4 Lb. 20c. Lb. 65c. 165 . Lucullus. The New Swiss Chard or Spinach Beet. But can be served both as Asparagus and as Spinach. De-
liclous. Pkts. 5e and 10c. 1/2 Oz. 10c. Oz. 15c. $1 / 1$ Lb. 30c. liclous. Pkts. 5c and 10c. 1/2 Oz.

341. Swiss Chard or Silver Beet. Grown exelusively for the foliage, which cooked makes most delicious greens. Pkts. $5 \mathrm{c}$ and 10c. Oz. 10c. $1 / 1 / \mathrm{Lb}$. 25c. Lb. $85 \mathrm{c}$.

\section{SUGAR BEETS}

1153. Giant Feeding Sugar Beet or Half Sugar Mangel. This magnificent Sugar Beet, while giving nearly as large a yield of easily grown and harvested roots as a crop of Mangels, supplies a food of very much higher nutritive value, the roots for feeding purposes being really more valuable, pound for pound, than those of the very best strains of Sugar Beet, and the yield under equally favorable conditions being more than double. The roots grow partly out of the ground, and because of this and their shape the crop can be harvested and stored at less expense than any other root crop. We are certain that every one who plants this variet, and grows it with care will be murch pleased with the crop. Every farmer sho
Pkts. 5c and 10c. Oz. 10c. 1/4 Lb. 20c. Lb. 60c. other Sugar Beet It may be distinguished by its brigh color and its lighter colored leaves, which are beautifully undulating, and scalloped around the edges; while not as a rule equal to the Vilmorin in Saccharine richness, it is considerably more productive. Pkts. 5c and 10c. Oz. 10c. Lb. 20c. Lb. $60 \mathrm{c}$.

360. Lane's Improved Sugar. An American rariety and the best stock-feeding Beet known. It is not so sweet but the roots are longer and finer grained: very sweet. Pkts. 5c and 10c. O\%. 10c. 1/4 Lb. 20c. Lb. 60c.

\section{MANGEL WURZEL Write for special prices in large quantities.}

Culture. Sow 5 pounds to the acre in April or June, in rows 3 feet apart, and thin to 9 inches in the row. an abundant crop of roots for Winter use.

1151. New Jumbo Mangel. For milch cows and cattle generally the new Jumbo Mangel has no equal. It is a milk producer of the highest quality and at the same time keeps the cattle over Winter in prime conditlon. It will outyield any other Mangel two to one. It is easy to grow, $\mathrm{Oz}$. 10c. $1 / 4 \mathrm{Lb}$. $20 \mathrm{c}$. Lb. $60 \mathrm{c}$.

1152. Gate Post Mangel. The name indicates the immense size of this fine flavored Mangel. Among the Yellow Mangel it stands supreme. The millk it produces when fed to cows is of the richest character. Pkts. 5c and 10c. $\mathrm{Oz}$. 10c. 1/: Lb. $20 \mathrm{c}$. Lb. 60c.
1153. Giant Mammotl Long Red Mangel. Our stock is a great improvement on the old variety. The roots are very large, uniformly straight and well formed. Color deep red, roots solid, tops small. Roots attain a large size. ing 20 to 23 pounds each. Produces an immense bulk and tonnage. Pkts. $5 \mathrm{c}$ and $10 \mathrm{c}$. Oz. 10c. 1/4 Lb. 20c. Lb. 50c.

1154. Improved Golden Tankard Mangel. We recommend it as the best Mangel by far for dairy farmers. It combines apparentl, all the fine points possible to condense into a Mangel. The color is a deep, rich yellow. The flesh is firm and solid and a rich, golden yellow

ts. $5 \mathrm{c}$ and $10 \mathrm{c} .0 \mathrm{z} .10 \mathrm{c} .1 / 4$ Lb. 20c. Lb. 50c.
359 . Golden Giant Intermediate. Root intermediate between the long and the glote-shaped. Flesh white, firm and sweet, much liked by cattle. Plkts. $5 \mathrm{c}$ and $10 \mathrm{c}$. Oz. $10 \mathrm{c}$. $1 / 4$ Lb. 20c. Lb. $50 \mathrm{c}$. 
We Pay Postage on All Cabbage Seed-Everywhere

Cabbage one 0 . will produce about 2,500 plants.

\section{Bolgiano's High-Bred American-Grown Cabbage Seed Will Produce the Best Crop You Have Ever Grown}

No vegetable is of greater importance to the market gardener than the Cabbage, and to many growers the success cause it is cheap. Much of the seed sold at a low price is imported from European countries where, owing to the climate, it produces large quantities of seed; but it is practically worthless in America. We exercise exceptional care in growing and selecting our Cabbage seed. It is all high-bred American-grown, except such varieties as should be grown abroad to get the best results such as the Danish Ball Head.

Culture. Soil for Cabbage should be rich and heary loam, with good drainage. On such a soil, with an abundance of stable manure, excellent crops are sure to be grown. For early Spring sow in Fall, not too early, or the plants are liable to bolt in the Spring, instead of heading. In a month the plants will be fit to transplant to cold frames where they are wintered, taking care in planting to set the young plants down to the first leaves. Transplant in spring as soon as the ground can be worked, setting the plants 2 feet apart one way and from 12 to 18 inches the other, according to the rariety. For late or Winter crops, the seed is sown in May, and the plants set out in July. In this case they are
set in rows 2 by 3 feet, so as to work them with a horse and cultivator.

In Lots of 5 Lbs. or More Deduct 10c Per Lb.

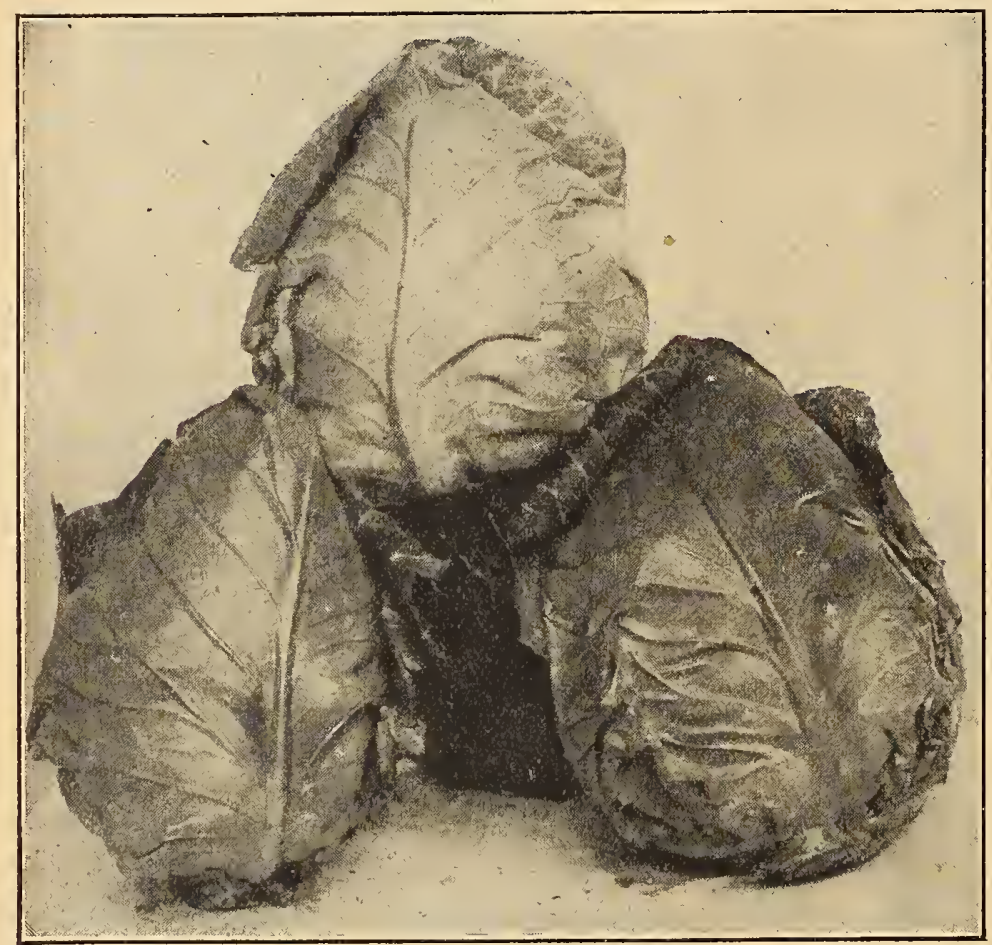

Bolgiano"s Selected Jersey Wakefield Cabbage

\section{Exúra Early Cabbage}

25. "Big Winner" Wakefield. We introduced this remarkable Cabbage eight years ago. It met with a hearty reception from every one who grew it. Every year we receive a great many letters of praise and congratulation regarding the Big Winner Wakefield Cabbage. No other Cabbage of which we have knowledge has aroused such enthusiasm among Cabbage growers as has our Big Winner Wakefield. It has the same Big Winner Wakedield. It has the same tield Cabbages, the heads being conical with a rounded or blunt point. It is, however, far superior to other strains of Wakefield Cabbage, being nearly double the size and better quality, and at the same time is fully as eariy. It has few outer leares, permitting close planting, so that more heads can be grown to the acre than with other sorts. Large Pkts. $5 \mathrm{c}$ and $10 \mathrm{c}$. $1 / 2 \mathrm{Oz} .20 \mathrm{c} . \mathrm{Oz}$ 35c. 2 Ozs. 65c. $1 / 4$ Lb. $\$ 1.15$. Lb. $\$ 1.00$.

27. Extra Early Express. This, the earliest of all Cabbage, has produced marketable heads in 80 days from the sowing of the seed. It can be planted close and yields large, early paying crops. Pkt. 10c. $1 / 2$ Oz. 20c. Oz. 35c 2 Ozs. 60c. $1 / 4$ Lb. $\$ 1.10$. $1 / 2$ Lb. $\$ 2.00$. I b. $\$ 3.75$.

26. New Leader. As early as the Wakefield, yields 12,000 heads, one-third more per acre than any other extra early Cabbage. The outer leaves are so few and so small that they can be planted very close. The heads are compact and solid from the time a head is formed and keens so until thoroughly matured, thus enabling extremely early cutting of small, hard heads, or later when the Wakefield comes in, of large, thoroughly matured, solid, round, flat heads. Pkts. 6. $\mathrm{c}$. $1 / 1 / \mathrm{Lb}$. $\$ 1.15$. $1 / 2$ Lb. $\$ 2.15$. Lb. $\$ 4.00$. 34. Early Winnigstadt. Prize Stock. The popularity of Winnigstadt Cabbage in all sections of the world is proverbial, but there is a great difference in the quality of the stocks. Some will produrce heads of twice the size o others; the finest is grown in Northern Prussia. It is from this section that our famous stock was introduced a few vears ago. It has become very popular with our market gardeners. Pkts. 5c. and 10c. Oz. 30c. $1 / 4 \mathrm{Lb}$. 90c. $1 / 2 \mathrm{Lb}$ $\$ 1.75$. Lb. $\$ 3.25$.

266. "Copenhagen Market," New Early Danish Cabbage. is earl, as Charleston Wakefield. This new Cabbage is very heavy and solid, like the Danish "Ball Head" type of Cabbage; makes a fine, large, globe-shaped head with well-developed outside leaves, but is very much earlier in maturing than any of the Danish Cabbages, and makes a very fine early variety, coming in about two weeks later than the "Early Jersey Wakefield." 'The heads weigh 14 to 16 pounds each. The seed is very scarce this year. Pkt. 16 pounds each. The seed is very scarce this year. Pkt.

373. Enkhuizen Glors. Is a valuable, early variety. It produces fine, remarkable heads and is a splendid soit for. the private garden and market gardener who grows for the private garden and market gardener who grows for outer leaves and of such compact growth to permit close planting, The quality is excellent. Pkts. 5c and 10c. $1 /$

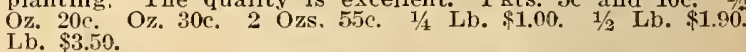

462. Bolgiano's New "Early Spring" Cabbage. Extra Early, Enormously prolific. Heads extremely compact and solid. A fine market sort and a superior shipper. Plkt. $5 \mathrm{c}$ and $10 \mathrm{c}, 1 / 2$ Oz. $20 \mathrm{c}$. Oz. 35e. 2 Oz, 60c. $1 / 2$ Lb. $\$ 1.10$ $1 / 2$ Lb. $\$ 2.00$. Lb. \$3. 5 . Postpaid.

376. Eureka Cabbage. An extra early flat variety. Pkts. je and 10c. Oz. 35e. 1/2 Lb. \$1.10. Lb. \$3.75.

29. Extra Ear?y Pilot Cablage. American Grown. Three weeks earlier than the Jersey Wakefield. Pkts 5c and 10c. Oz. 35. $1 / 1 / 2$ Lb. $\$ 1.10 . \quad$ Lb. $\$ 3.75$. 


\section{Cabbage}

Second Early Varieties

We Pay Postage On All Cabbage SeedEverywhere

In Lots of 5 Lbs. or More Deduct 10c Per Lb.

154. Bolgiano's Early "Square Deal" Cabbage. The best on Earth. The heads are solid and compact, with very heads are solid and compact, with very few outer leaves. For a fine, solid, tender, uniform, early, flat Cabbage, Bolchallenges the world. The demand for a Cabbage of this character led us by the most rigid and careful selection durring tbe past five years to mature this Cabbage, wbich we are confident will give all our friends and customers a "Square Deal" every time. Pkt. 10c. $1 / 2$ Oz. 20e. Oz. 35c. 2 Ozs. 65e. 1/4 Lb. $\$ 1.15$. $1 / 2$ Lb. $\$ 2.15$. Lb. $\$ 4.00$.

35. Bolgiano's "New Farly" Cabbage. It forms solid, compact, round, flat heads, the leaves growing close to tbe head, tbus allowing more cabbage to be grown to the acre than any other sort. Its earliness (a week before other early, flat varieties) is one of its best marketable features. It heads so bard and so quick it becomes waterproof. Pkts. 5c and 10c. Oz. 35e. 1/4 Lb. \$1.10. Lb. $\$ 3.75$. 36. Florida Header Cabbage. In color, shape and size the heads are most uniform. Pkts. 5e and 10c. Oz. 30c. 1/9 Lb. $\$ 1.00$. Lb. $\$ 3.50$

37. All Head Early Cabbage. For uniformity, reliability of heading, size, earliness and quality it is very superior. lts beads grow compact and free from spreading leaves. Pkts, 5c and $10 \mathrm{c}$. $\mathrm{z}$. 30c. $1 / 1$ Lb. $\$ 1.00$. Lb. $\$ 3.50$.

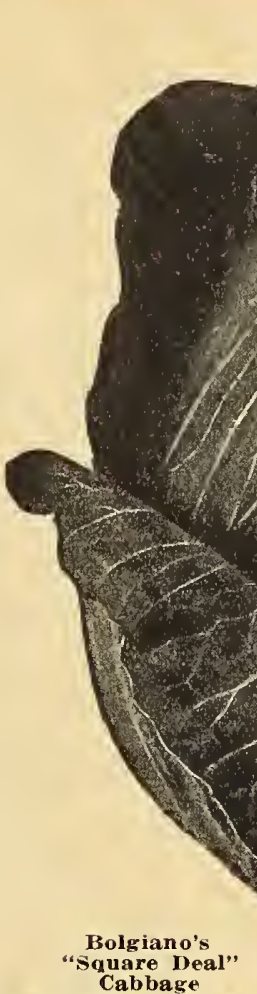

148. Brunswick, Fottlex"s Cabbage. In this vicinity the Brunswick is considered second to none by tbe market gardeners. Plants are very short stemmed; large leaves and very compact. Heads are Iarge, flat solid and of fine and quality. Pkts. 5c and 10c. Oz. 30c. 1/4 Lb. $\$ 1,00$. Lb. $\$ 3.50$. 38. Henderson's Early Summer Cabbage. In size, form,
solidity and earliness this is truly a model Cabbage. It heads just after our Jersey Wakefield. Pkts. 5c and 10c. Oz. 30c. $1 / 4$ Lb. $\$ 1.00$. Lb. $\$ 3.50$.

39. Long Island, Early, Flat Dutch Cabbage. The beads are large and solid and mature very early-just after tbe select Jersey Wakefield, and may be marketed at the same time witb the Wakefield. Pkts. 5c and 10c. Oz. 30c. 1/4 Lb. $\$ 1.00$. Lb. $\$ 3.50$.

40. Early, Short Stem, Drumhead Cabbage Seed. It is leady for marketing 2 or 3 weeks earlier than the late Drumheads, forms large, solid, rounded beads weighing from 15 to 25 pounds. Pkts. 5c and 10c. Oz. 30c. 1/4 Lb. 90c. $1 / 2$ Lb. $\$ 1.75$. Lb. $\$ 3.25$.

41. Henderson's Early Succession Cabbage. A wonderful Cabbage for solidity, productiveness and fine, large heads. Matures early, hs bandsome color and fine quality. Pkts. $5 c$ and $10 \mathrm{c}$. Oz. 30c. $1 / 4$ Lb. $\$ 1.00$. Lb. $\$ 3.50$.

42. Sure Head Cabbage. Pedigree Stock.) True American grown. Produces large, round, flattened beads that are all head, with fewer outer leares, very uniform, firm and weigbs from 10 to 15 poimds each. Pkts. 5e and $10 \mathrm{c}$. Oz. 30c. $1 / 4$ Lb. 85c. Lb. $\$ 3.00$

542 . Solid South. This is one of the purest and truest Cabbages ever bred. Produces very large, sbapely, solid heads. It is crisp, fine grained and of delicious flavor. An excellent shipper. Pkts. 5e and 10c. 1/2 Oz. 20c. Oz. 30c. $1 / 4$ Lb. $\$ 1.00$. $1 / 2$ Lb. $\$ 1.90$. Lb. $\$ 3.50$.

53. Bolgiano's Perfection Drumhead Savoy Cabbage. Surpasses all varieties of Savoy Cabbage for uniformity of heads, beauty of curl and superior keeping qualities. Pkts. 5c and 10c. Oz. 30c. $1 / 4$ Lb. $\$ 1.00$. Lb. $\$ 3.50$

49. Mammoth Red Dutch. Is the largest Red Cabbage, and heads very solid and is deep red in color to tbe very center, Pkts. 5c and 10c. 1/2 Oz. 25e. Oz. 50c. 2 Ozs. $80 \mathrm{c}$ $1 / 4$ Lb. $\$ 1.40$. 1/2 Lb. $\$ 2.65$. ${ }^{2}$ Lb. $\$ 5.00$.

375. Volga. One of the earliest, main crop Cabbage of superior quality. Round bead, short stem, compact growtb. exceptionally bardy and a good keeper. Pkts. 5c and 10c Oz. 30c. $1 / 4$ Lb. $\$ 1.00$ Lb. $\$ 3.50$

374. A!l Seasons. An "all-season" variety, equally good for Fall and Winter as for summer use. The heads are large, solid, round, flattened on top, and of best quality. Pkts. $5 \mathrm{c}$ and 10c. Oz. 30c. 1/4 Lb. $85 \mathrm{c}$. Lb. $\$ 3.00$.

96. Bolgiano's "Ringleader," Large, Late, Flat, Dutch Cabbage, Will always produce heads of enormous size and of the very finest quality. Pkt. 10c. $1 / 2 \mathrm{Oz} .20 \mathrm{c}$. Oz. 35c. 2 Ozs. 65e. 1//4 Lb. $\$ 1.15$. 1/2 Lb. $\$ 2.15$. Lb. $\$ 4.00$.

43. Bolgiano's Fxtra Large, Late, Flat, Dutch; Market Gardener's Choicest Stock. Can be planted later than the oldtime varieties and matures more quick iar than the some. EXTRA LARGE. solid. uniform Cabbage of perfect keeping qualities. Plsts. 5c and 10c. Oz. 30c. $1 / 1 \mathrm{Lb}$. $90 \mathrm{c}$ keeping qualities. Plsts.
$1 / 2$ Lb. $\$ 1.75$. Lb. $\$ 3.25$. 
Parcel Post Rates, see Page 2

One ounce of seed will produce about 3,000 plants

One-half ounce furnished at ounce rates, and one-half pounä furnished at pound rates

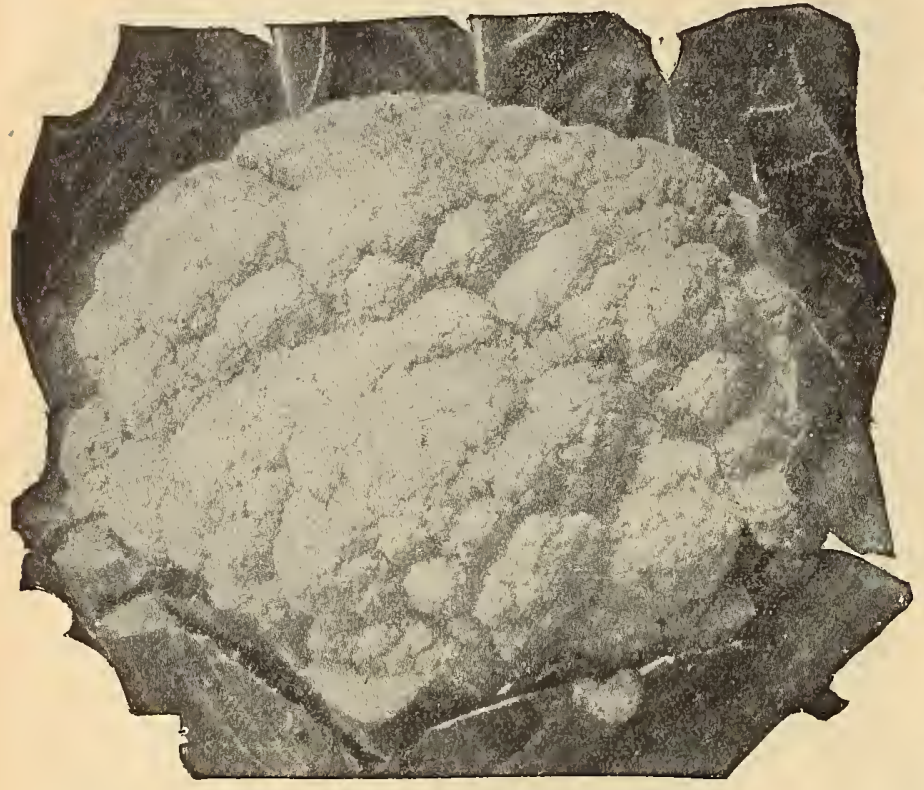

Bolgiano's Earliest Snow Ball Cauiflower

\section{Cauliflower}

Culture. For earliest Cauliflower, raise plants by sowing in hotbed or greenhouse during January or February, and transplant to flats or cold frames, 2 or 3 inches apart each way. Set in open ground as soon in Spring as the land can be put in good order. Soil to be a warm, very rich, fibrous loam, well supplied with humus and moisture. Copious water application during dry and light dressing of are of much help. Set plants 2 to $2 \frac{1}{2}$ feet apart each way. For late Cauliflower to mature during pickling season (August 15 to October 10) start plants in open ground like late Cabbages, and handle them like that crop. After the heads begin to form, draw leaves over and pin or tie tñem together to protect the head from the sun.

\section{New Century Cauliflower}

\section{The Best in the World}

1. It heads when others fail. 2. Large, perfect heads, measure from 12 to 14 inches in diameter. 3. The beautiful white heads are compact, deep and solid. 4. Heads will outweight those of any other strain. 5. It is the earliest of all Cauliflower. 6. One-third more can be planted on the same space than can be done with other varieties because of its close growing, compact

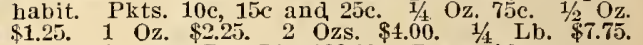
$1 / 2$ Lb. $\$ 14.50$. Per Lb. \$28.00. Postpaid.

105. Danish Giamt or New Dry-Weather Cauliflower. Will produce splendid crops in very dry locations. Pkts. 10c and 25c. 1/4 Oz. 40c. 1/2 Oz. $\$ 1.00$. Oz $\$ 1.75$, 1/4 Lb. $\$ 5.50$. Lb. $\$ 20.00$. Postpaid. 55. Snow IBall Earliest Cauliflower. Our Snow Ball Cauliflower is the earliest, most hardy, and, in fact, the Cauliflower that you can plant and expect a crop of true, firm, snow-white heads. from 10 to 12 inches in diameter. Best for forcing: best for Wintering over early crop Every plant will produce a fine head. Pkts. 5c, 10c and $25 \mathrm{c}$. 1 oz. $\$ 1.00$. O\%. $\$ 1.75$. 2 Ozs. $\$ 3.00$. 1/4 Lb. $\$ 5.50$. 1/2 Lb. $\$ 10.50$. Lb. $\$ 20.00$. Postpaid.

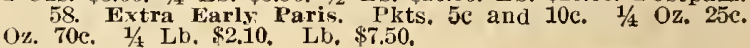

59. Erfurt Extra Early Dwarf. Extra Selected First Ozs. Pkts. 5e, 10c and 25c. 1/2 Oz. $\$ 1.00$. Oz. \$1.7

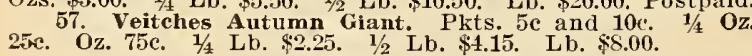

\section{One ounce will sou 100 feet
of drill, 3 or 4 pounds}

In Lots of 5 Lbs. or More Neduct 5c Per Lb.

Culture. Carrots do best in warm, deep, rather light and fairly fertile soil that is well supplied with humus, or on strong loam, having been in clover and broken the year before. For earliest crop, sow seed of the early, short-rooted sorts in April or inches. For main crop, sow in May or Tune, or for succession even in July, using the long-rooted varieties. The rows for these may be 16 to 20 inches apart, and the plants thinned to 2,3 or even 4 inches. 91. New King Carrot. The greatest Carrot introduced in the last 10 years. Pkts. $5 \mathrm{c}$ and 10c. Oz. 15c. 2 Ozs. 25c. 1/4 Lb. 30c. 1/2 Lb. 55e. Lb. $\$ 100$. Postpaid.

14. Early Sunbeam. Bolgiano's New, Extremely Early Carrot. This beautiful, delicious, exceptionally early forcing Carrot comes at the time of the year when new vegetables are most appreciated and enjoyed. Be sure to plant some. Plits. $5 c$ and 10c. Oz. 15e. 2 Ozs. 25c. 1/4 Lb. $30 \mathrm{c}$. $1 / 2$ Lb. 55c. Lb. $\$ 1.00$. Postpaid.

8. Klondike or Coreless Carrot. An entirely new variety, glows 6 to 7 inches long and $1 \frac{1}{4}$ inches through. Color, rich orangered. Pkts. 5e and 10c. Oz. 10c. 2 Ozs. 15c. $1 / 4$ Lb. 25c. 1/2 Lb. $45 \mathrm{c}$. L $85 c$

60. Scarlet Beauty Carrot. 1. A handsome and prolific Calrot. 2. Rich deep searlet in color. 3. In length, between long and half-orange. 4 . Very straight roots. 5 . Very little foliage for size of roots 6 . Delicious flavor. $\bar{t}$. Heavy yielder. S. Uniform in size. 9. Often $21 / 2$ to 3 inches at and 10c. Oz. 10c. 2 Ozs. 15c. i/t Lb. $25 \mathrm{c}$. $1 / 2$ Lb. 45 c. Lb. Súc. Postpaid. 64. Pride of the Market Carrot. Has led all Half-Long Carrots for 10 sears. Pkts. $5 \mathrm{c}$ and $10 \mathrm{c}$. Oz. 15c. 2 Ozs. 25c. 1/4 Lb. 30c. $1 / 2$ Lb. 55c. Lb. $\$ 1.00$. Postpaid. early, so shapely, so tender, and of such a fine, bright scarlet color. Pkts. 5c and 10c. Oz. 10c. 2 Ozs. 15e. $1 / 4$ Lb. $25 \mathrm{c} .1 / 2$ Lb. 40c. Lb. 75c. Postpaid.

356. Parisian Forcing Extremely Early Carrot. For hotbeds, greenhouses or very early cold frames. Pkts. $5 \mathrm{c}$ and $10 \mathrm{c}$. Oz. 15c. 2 Ozs. 25c. 1/4 Lb. 30c. $1 / 2$ Lb. 55e.
61. IIalf-Long Orange Carroi. The skin is clear, bright in color and the flesh is close in texture, of very fine grain, with rery small core. Pkts, $5 \mathrm{c}$ and $10 \mathrm{c} .0 \mathrm{z} .10 \mathrm{c}$. 2 Ozs. 15c. $1 / 4$ Lb. $25 \mathrm{c}$. $1 / 2$ Lb. $40 \mathrm{c}$. Lb. 2 Ozs. $15 \mathrm{c}$. $1 / 4$

62. Improved Long Orange Carrot. Uniformly a deep orange color, growing a long, smooth, syminetrical Carrot. Remarkable for the absence of the detractive side roots and divisions at the point. Tremend. ous yielder and of a rich, sweet flavor: Pkts. 5c and 10c. Oz. 10c. 1/4 Lb. 20c. 1/2 Lb. 35c. Lb. 65e. Postpaid.

65. St. Vazery, Long Ped. Color, orangered. Roots large and handsome, intermediate in shape between Danvers and Long Orange, Pkts, 5c and 10c. Oz. 10c. 1/4 Lb. 25c. 1/2 Lb. 40c. Lb. T5c. Postpaid.

66. Early Scarlet Horn. A very popular sort; quick growing; deep orange in color: blunt rooted; six to eight inches in length Pkts. 5c and 10c. Oz. 10c. 1/1 Lb. 25c. $1 / 2$ Lb. 40c. Lb. Tõc. Postpaid.

67. Danvers Half Long. One of the heaviest cropper's, roots dark orange color ; eight to ten inches in length, thick and ending in a somewhat abrupt point. Plits. sc and 10e. Oz. 10e. 1/4 Lb. 25e. 1/2 Ll. 40c. Lb. 75c. Postpaid.

68. Chantenay or Model. Early, scarlet color, stump rooted, broad, thick showlder, heav cropper. Pkts. $5 \mathrm{c}$ and $10 \mathrm{c} . \mathrm{Oz} .10 \mathrm{c}$ $1 / 4$ Lb.. 25c. 1/2 Lb. 40c. Lb. Tue. Postpaid. 69. Nantes, IIalf Long, Stump Rooted. Iioots 8 to 10 inches in length, thick shouider, deep orange and good cropper Plt. 10c. Oz, 10c. 1/4 Lb. 25c. 1/ Lb. 40c. Lb. 75c. Postpaid

70. Rubicon. Early, half-loug, stump rooted : color deep orange; of finest quality. Pkts. 5e and 10c. Oz. 10c. 2 Ozs. I5c. $1 / 4$ Lb. $25 \mathrm{c}$. $1 / 2$ Lb. 40c. Ib. 75c. Postpaid. 570. James' Intermediate Scarlet. Roots similar in shapo and size to Danver Pointed; color searlet; nearly coreless. Pkts. 5e and 10c. Oz. 10c. i// Lb. 20c. $1 / 2$ Lb. 35e. Lh. 65e. Postpaid.

361. Large, White Belgium Carrot. These

Carrots are grown for feeding stock during Pride of the Yarket Carrot

Winter. Pkts. $5 c$ and 10e.

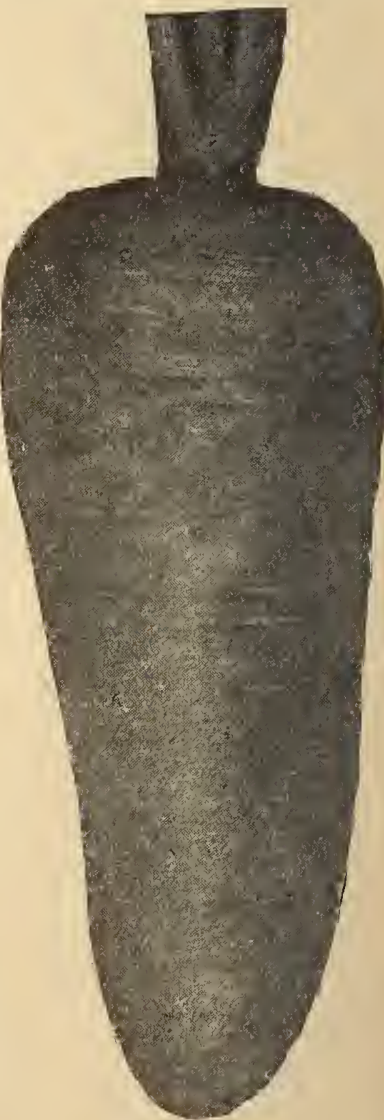




\section{Pkts., Ozs, and ${ }^{1 / 4}$ Lbs. Delivered Celery Parcel Post Rates \\ In Lots of 5 Lbs, or More $10 \mathrm{c}$ Per Lb. Less.}

Cuiture. One ounce will produce about twenty-five hundred lants and sow about two hundred feet of row. Sow the last of March or early in April, in an open border, in rich, mellow ground in shallow drills, watering freely in dry weather. By rolling or pressing in the seed the result will be more satisfactory than when only covered. Cut the tops off once or twice before planting out, to make them stocky. Whell the plants are 5 or 6 inches high, to make them sarieties 3 feet and the taller sort 4 feet transplant the rows. Cultivate betrieen the rows; plant 6 inches art in the rows. The first well and when large enough, , blanch by earthing up. The first operation is that of "handling," generally done by the beginning is drawn around each plant by hand to keep the leaves firm in upright position and prerent spreading. When plauts have become "set" in an upright position aud the Celery is wanted for early soil up as close to the plants as possible with a plow and the soil up ath a spade, bringing the earth nearly up to the finishing tops or the plants. The method emplos the tops of the banks with waterproof felt paper.

\section{Bolgiano's French Golden Self-Blanching Celery}

It is used Exclusively by the Largest and Most Experienced Celery Growers and annually produces Enormous Profits. This is the finest

i1. While you can readily afford to put sour whole crop in our stock of this most valuable Celery, you cannot aftord to let this year go by without growing some of it. We have positively The Celery it produces will not only ship well, but will bring the highest market prices. It will create a new price for your; youl highest market prices, quickly all rou can ship. Try our stock; YoUR PRAISES will be louder than ours. Perfect, solid, crisp, rigorous stalls; thrifty, compact growth, self-blanching to a very remarkable degree; even the outer ribs become a handsome, fresh, clean, jellowish color, with a heart that is large and solid, of a beautiful rich, goldenyellow color. It never becomes stringy or pethy. To fully appreciate its beauty and attractions, in to be sure of this stock of seed. Plit. 10c. 1// Oz. 25c. 1/2 Oz. 40c.

395. Golden Self-Blanching. (American-Grown Seed.) An early sort, requiring but little labor to blanch. Heart rich golden yellow, with light yellowish-green outer leaves. This Celery is in condition for use early in the Fall. Plsts. The and 10c. $1 / 20 z .15 \mathrm{c} .0 z .25 \mathrm{c}$. $1 / 4 \mathrm{Lb}$. $75 \mathrm{c}$. $1 / 2 \mathrm{Lb}$. $\$ 1.35$. Lb. $\$ 2.50$.

76. Sweet Nut Celery. Most delicious Celery grown. We recommend it for nearby markets and home use. Pkt. 10c. 1/2 Oz. 15c. Oz. 30c. 2 Ozs. 55c. 1/1 Lb. 85e. 1/2 Lb. $\$ 1.60$. Lb. $\$ 3.00$. Postpaid.

73. Giant Pascal Celery. This is a large, solid, excellent sort. It blanches rery quickly to a beautiful, yellorish-white color, is very solid and crisp, and a fine, nut flavor. Stalks grow broad and thick, a single branch mak ing a large bunch. Pkts. 5c and 10c. 1/20z. 10c. Oz. 15c. 2 Ozs. $25 \mathrm{c}$. 1/4 Lb, 45c, 1/2 Lb. 80c. Lb. \$1.50. Postpaid.

81. New Vietory Solid French Grown. The Very Best

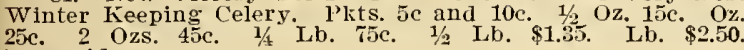
Postpaid.

79. The Pearl Le Grand Celery. Keeps in perfect condition orer winter and after other sorts are gone. Its large golden heart has a rich, nutty flavor. Pkts. 5c and 10c. Oz. $15 \mathrm{c}, 1 / 4$ Lb. $45 \mathrm{c}$. Lb. $\$ 1.50$.

\section{Corn Salad}

1 Ounce will sow 20 square feet, 6 pounds will sow an acr

Culture. Sow during August or early in September, in drills $1 / 4$ inch deep and 6 inches apart. If the weather is dry when the seed is somn, tread it lightly to insure germination. Keep down weeds with hoe. Just before the Winter cover thinly with straw or leaves.

24. Large German Corn Salad. Used as a salad and for garnishing. Plit. 5e. Oz. 15e. 1/1 Lb. 40c. Lb. $\$ 1.25$.

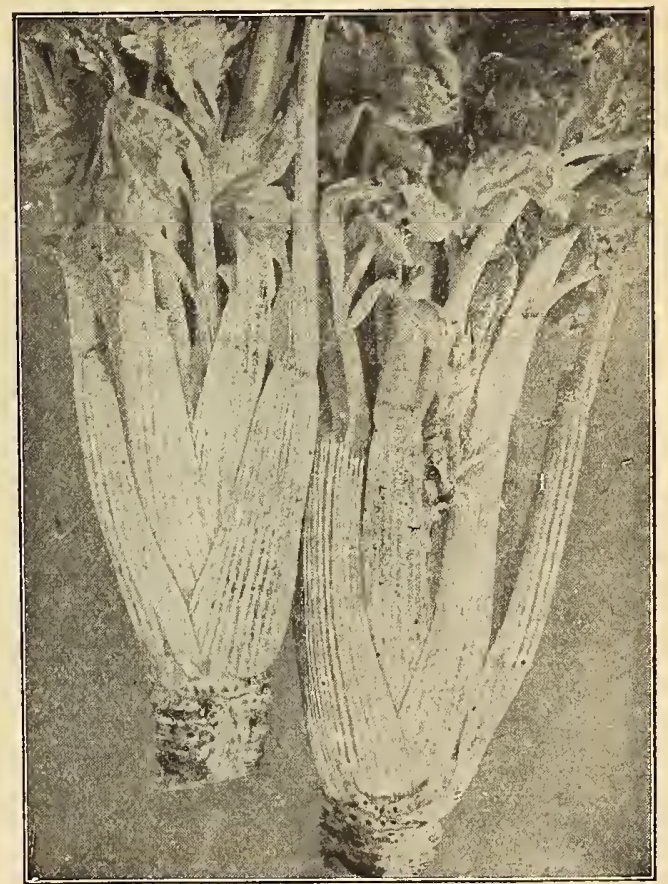

Bolgiano's New Victory Celery his 6. Giant Golden Heart Celery A gardener found in is cart Golden Heart a few plants ar laser growth. Golden Giant Heart, which excels for larger size, solidity and keeping quality. Pkts. $5 \mathrm{c}$ and $10 \mathrm{c}$. Oz. 15c. 2 ozs. $25 \mathrm{c}$ $1 / 4$ Lb. 45c. 1/2 Lb. S0c. Lb. \$1.50. Postpaid.

72. Perfected White Plume Ce:ery. Is the most ex tensively used on account of its extreme earliness. Its stalks and portiolis of its inner leaves and heart are white naturally. By simply tying the plant together, or by drawing the soil firmly against the plant with the hand and repeating the operation to hold the soil already against the plant in nosition, the work of blanching is completed. Pkts. $5 \mathrm{c}$ and $10 \mathrm{c}$ (1/20z $15 \mathrm{c}, \mathrm{Oz}, 25 \mathrm{c}, 2 \mathrm{Oz}, 45 \mathrm{c}, 1 / \mathrm{Lb}$ $1 / 2$ Lb. $\$ 1.35$. Lb. $\$ 2.50$. Postpaid.

75. New Winter Queen Celery. (Pedigree Stock.) A good keeper aud beautiful in appearance. Ribs perfectly solid, crisp and of a delicious, nutty flavor. Pkts. 5c and 10c. Oz. 15c. $1 / 4$ Lb. $45 \mathrm{c}$. $1 / 2$ Lb. $80 \mathrm{c}$. Lb. $\$ 1.50$. Postpaid. 74. Dwarf Golden Heart Celery. Is crisp, solid, hand some and most excellent flavor, with a beautiful Golden Postpaid.

Celery Seed for Flavoring (Soup Celery). Plits. $5 c$ and 10c. Oz, 10c. $1 / 2$ Lb. $25 \mathrm{c}$. Lb. $75 \mathrm{c}$.

Cress Cresson-Berro o Mastuerzo-Kreffo. Culture, Sow erers 2 weeks. It should be cut often and will continue to grow. It is useful for salad and for garnishing.

grow. It is useful for salad and for garnishing. or if a stream of water can be utilized, they would be murch finer. They will thrive well in damp hotbeds. lightly managed, their culture is rery profitable. To obtain early salad it is a good plan to sow with Water Cress Seed a inside the frame where it is always Oz. $25 \mathrm{c}$. 2 Ozs. $45 \mathrm{c}$. 1/4 Lb. 75 c. Lb. $\$ 2.50$. Postpaid.

L21. Fine Cur'ed $25 \mathrm{c}$ Lb. $75 \mathrm{c}$.

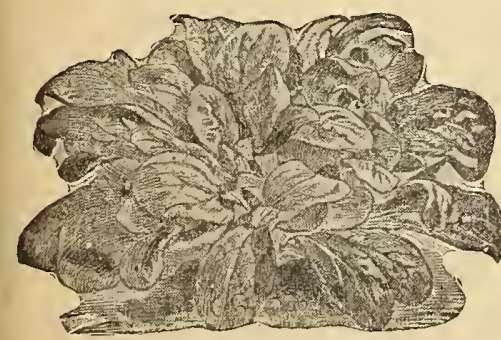

Large German Corn Salad

\section{Celeriac, or Turnip-Rooted Celery}

Culture for Root Celery. Sow the seerl at the same season and give the same reatment as Celery. Transplant the young plants to moist, rich soil in rows feet apart and 6 inches apart in the row.

139. Giant French Celeriac. There is not a single item of interest in the growing and developing of seeds that we pass by without most thoroughly investigating and testing to see if there is something of value to our customers. To prove our watchfulness, we are here introducing the Giant French Celeriac. Many thought the Celeriac, which the Market Gardeners have had for years, was good for our pains by being able to offer this splendid Celeriac. Pkts. 5c and 10c. O\% 20c. 2 Ozs. 35c. 1/4 Lb. 60c. Lb. \$2.00. Postpaid.

83. Large, Smooth Prague Celeriac. A large Celery-flavored root used extensively for flavoring soups, pickles, etc.; also relished sliced as a salad with pepper and vinegar. It is also used to flavor chicken and potato salad. Pkts. $5 c$ and $10 \mathrm{c}$. and vinegar. It is also used to flavor chicken and potato salad. 2 Ozs. 25c. $1 / 4$ Lb. 45c. $1 / 2$. $80 \mathrm{c}$. 


\section{Sweet or Sugar Corn}

We suppiy packages of Sweet Corn at $5 c$ and $10 \mathrm{c}$ will Plant 20 Hills; 8 to 10 Quarts for an Acre in Hills

Sugar Corn, weight by Parcel Post: Pts., 1 Lb.; Qts., 2 Lbs.; 6 Lbs., Pl. 11 Lbs.

Culture. Seed of the sweetest varieties is liable to rot if planted in wet or cold ground. Yet if we have an early warm spell in Spring, it may pay us to take some risks. Often the plants, when once up, will escape infury by a belated light frost. Plant in warm soil 5 or 6 kernels to a hill, making the rows 3 feet apart for the dwarf or early sorts and 4 feet apart for the taller late sorts. Hills to be 2 to 3 feet apart in the row s, thin out to 3 plants in a hill. Hoe often and draw soil up to the stem, break off side shoots.

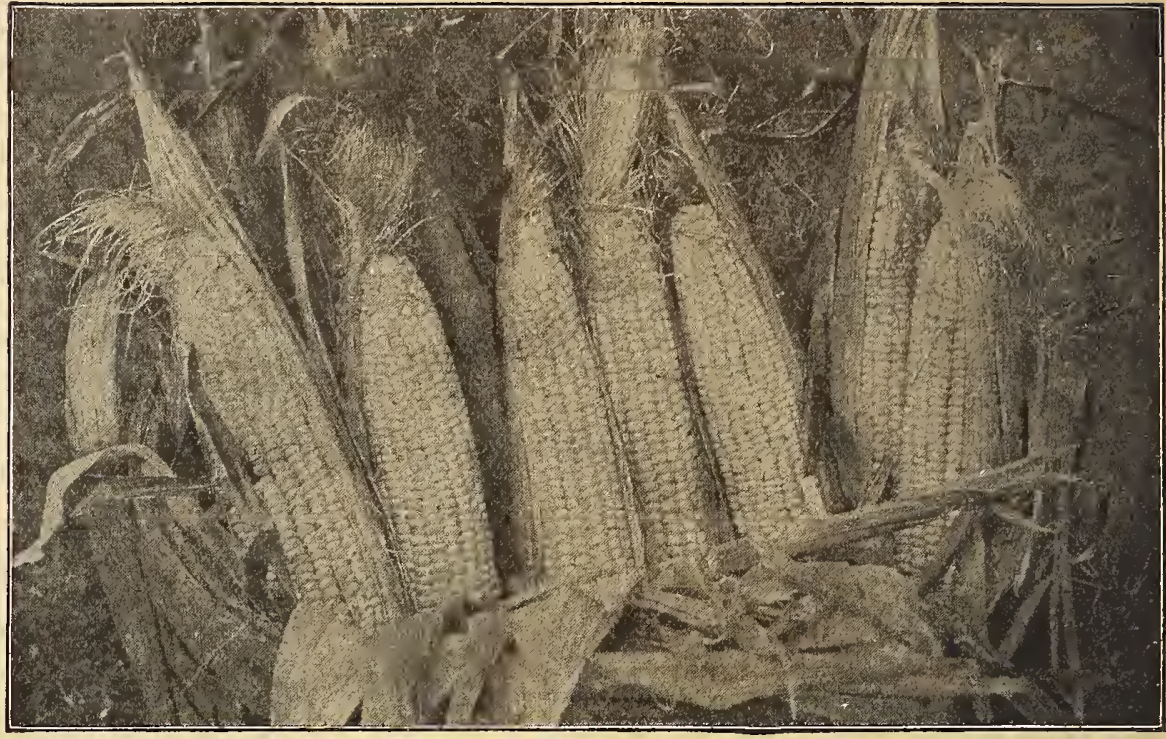

Snow White Evergreen Sugar Corn

\section{Extra Early Varieties}

1051. Double XX Extra Early Adams' Sweet Corn. Two weeks earlier than Extra Early Adams'. Per ear 6c. Doz. ears 60c. Pt. 20c. Qt. 30c. 4 Qts. \$1.10. Pk. $\$ 2.00$. Bu. $\$ 7.25$.

1052. Adams' Extra Early. A splendid early variety, largely grown for early market. Per ear 6c. Doz. ears 60c. Pt. 20c. Qt. 30c. 4 Qts. \$1.10. Pk. $\$ 2.00$. Bu. $\$ 7.00$.

1053. Second Early Adams'. Ears are larger and later than Adams' Extra Early, Per ear 6c. Doz. 60c. Pt. 20c. Qt. 30c. 4 Qts. 95c. Pk. $\$ 1.70$. Bur. $\$ 6.00$.

1050. Gillespie's First Early Patapsco Neck Corn. The very First Good Size Corn that can be brought to market. it is so hardy that it can readily be planted as soon as the ground is in good working order. Per ear 6c. Doz. 60c. Pt. 20c. Ot. $30 \mathrm{c}, 4$ ots. 95. $\mathrm{c}$ Pk. $\$ 1.80$. Bu. $\$ 6.00$.

1136. California Golden Country Gentleman Corn. This is a wonderful combination of the "Cream and Honey", Sugar Corn and the well-known "Country Gentleman" Sugar Corn. Pkt. 10c. Pt. 20c.

12231/2. Cory White Cob. A selection from Red Cory, having white kernels and white cob. Pt. 20c. Qt. 30c. 4 Qts. $\$ 1,10$. Pk. $\$ 2.00$, Bu. $\$ 7.50$.

12241/2. Red Cory. A very early variety, with good sized ears and large red grains. Pt, 20c. Qt. 30c 4 Ots. $\$ 1.10$. Pk. $\$ 2.00$. Bu. $\$ 7.50$.

1182. Bolgiano's New "Cream and Honey" Sweet Corn. Extremely early. most delicious flavor. exceptionally. fine quality. Pkt. 10c. Pt. 20c. Qt. 30c. 2 Qts. 55c. 4 Qts. $\$ 1.10$. Pk. $\$ 2.00$. Bu. $\$ 7.50$.

1005. Eariy "liutier-Nut" Sugar Corn. New Variety, follows "Cream and Honey" Sugar Corn by four to seven days. Pkt. 10e. Pt. 20c. Qt. 30c. 2 Qts. 55e. 4 Qts. $\$ 1.10$. Pk. $\$ 2.00$. Bu. $\$ 7.50$

1049. 65-Day White Cob Corn. This Extremely Early Corn looks like Snow White Evergreen Corn. Per ear 6e. Doz. ears 60e. Pkt. 10c. Pt. 20e. Ot. 30e. 2 Qts. 50e. Qts. 95c. Pk. $\$ 1.70$. Bu. $\$ 6.00$.

1256. Howling Mob. Superb long ears of sweetest quality. Stocks are of strong, vigorous growth $4 \frac{1}{2}$ to 5 feet in height. Pt. 20c. Qt. 35c. + Qts. $\$ 1.25$. Pk. $\$ 2.25$. Bu. $\$ 8.00$.

1112. Golden Bantam Corn. This very early, yellow grained Sweet Corn when in best condition for the table is. remarkably sweet and tender. Pkt. 10c. Pt. 20c. Qt. 30e. 4 Qts. $\$ 1.10$. Pk. $\$ 2.00$. Bu. $\$ 7.50$.

30c. 4 Qts. \$1.10; Pk. $\$ 2.00$. Noted for its large size and extrene earliness. Pt. 20c. Qt. 30c. 4 Qts. $\$ 1.10$. Pk. $\$ 2.00$. Bu. $\$ 7.50$.

1115. Premo 60-Day Corn. Experis pronounce this Corn to be from 5 to 7 davs earlier than any other. Sugar Corn in existence. Pt. 20c. Qt. 35c. 4 Qts. \$1.25. Pk. 25.313 .00

105u. \$8.00. vinnesota. Ears larger than the Cory 10 Crosby. Pt. $20 \mathrm{c}$. at 350 . 4 ts. $\$ 1.25$. Pk. $\$ 2.25$. Bu. $\$ 8.00$

1057. Mammoth White Coryi Sweet Corn. Produces ears 7 to 8 inches long: 12-rowed. Pt. 20c. Qt. 35c. Qts. $\$ 1.25$, Pk. $\$ 2.25$. Ru. $\$ 8.00$

\section{Second Early Varieties}

1068. Peen-o'-Day. The two noints to this remarkable Corn are its extraordinarv carliness and unparalleled sweetness. Prices: Pt. 20c. Qt. 35c. 2 Qts. 75c. 4 Qts. $\$ 1.25$. Pk. $\$ 2.25$. Bu. $\$ 8.00$.

1056. Early Crosby. Early, matures after Minnesota fair-sized ears of good quality. Pt. 20c. Qt. 35c. 4 Qts. $\$ 1.25$. Pk. $\$ 2.25$. Bu. $\$ 8.00$

1059. Earliest Sheffie'd Sweet Corn. Planted as early as Adams'. It will stand slight frost. Pt. 20c. Qt. 35c. 4 Qts. $\$ 1.25$. Pk. $\$ 2.25$. Bu. $\$ 8.00$

1060. Extra Early Everereen. Ears like Evergreenverr large. with about 18 irregular rows and a very long grain of the very best quality. Per ear 7c. Doz. ears 75c. Pt. 20c. Qt. 30c. 4 Qts. $\$ 1.10$. Pk. $\$ 2.00$. Bu. $\$ 7.00$.

1061. Early Mammoth Sugar. Market Gardeners' favorite. Two weeks earlier than the Late Mammoth. Pt. 20c. orite. Two weeks earlier than the Late Ma.
Qt. 30c. 4 ots. $\$ 1.10$. Pk. $\$ 2.00$. Bu. $\$ 7.00$.

1222 Truckers' Favorite. Not a Sugar Corn, but used largely in Baltimore and the South as a table Corn. Per ear 6c. Doz. ears 60c. Pt. 20c. Qt. 30c. 2 Qts. 55c. 4 Qts. 95. Pk. $\$ 1.70$ Bı $\$ 6.00$

\section{General Crop Varieties}

1066. Snow White Evergreen. Pcr ear 7c. Doz. ears, 75c. Pkt. 10c. Pt. 20c. Qt. 30c. 2 Qts. 55c. 4 Qts. \$1.10. Pk. \$2.00. Bu. \$7.00.

1067. Stowell's Evergreen. The truest strain of the leader of all Corns is in our possession. Per ear $7 \mathrm{c}$. Doz. ears 75c. Pt. 20c. Qt. 35e. 4 Qts. 95c Pk. $\$ 1.70$. Bu. $\$ 6.00$.

1255. Leonard's Narrow Grained Evergreen. Ears are as large as the Stowell's Evergreen and average more rows to the ears, being of a very narrow grain. Pkt. 10c. $\mathrm{Pt}$ 20c. Qt. 30c. 2 Qts. 55e. 4 Qts. $\$ 1.10$. Pk. $\$ 2.00$. Bu. $\$ 7.00$.

1137. Zig-Zag Evergreen Corn. An exceptionally sweet, delicious flavor Sugar Corn. Pt. 20e. Qt. 30e. 2 Qts. $55 \mathrm{c}$ 4 Qts. $\$ 1.10$. Pk, \$2.00. Pu. \$7.00.

1144. Hickox Improved. Handsome ears, very white and of very rich flavor. Pt. 20c. Qt. 30c. 2 Qts. 55e. Qts. \$1.10. Pk. $\$ 2.00$. Bir. $\$ 7.00$.

\section{Late Crop Varieties}

1065 Country Gentleman Sugar Corn. Pkt. 10c. Pt. 20c. Qt. 30c. 2 Qts. 55c. 1 Qts. $\$ 1.10$. Pk. $\$ 2.00$. Bu. $\$ 7.00$

1062. Large Late Mammoth Sugar. Pt. 20c. Qt. 30c. Gal. $\$ 1.10$. Pk. $\$ 2.00$. Bu. $\$ 7.00$.

1193. Shoe Peg or Ne Plus Ultra. Pt. 20c. Qt. 30c. 4 Qts. $\$ 1.10$. Pk. $\$ 2.00$. Bu. $\$ 7.00$.

1064. Rice Corn for Popping or Seed. Pt. 20c. Qt. 35c 4 Qts. $\$ 1.00$. Pk. $\$ 1.90$. Bu. $\$ 6.75$.

1054. Red-Cob 90-Day Corn. This Corn meets a longfelt want, because it suits the retail market sales. Pt. $20 \mathrm{c}$ Qt. 30c. + Qts. $\$ 1.10$. Pk. $\$ 2.00$. Bu. $\$ 7.00$. 


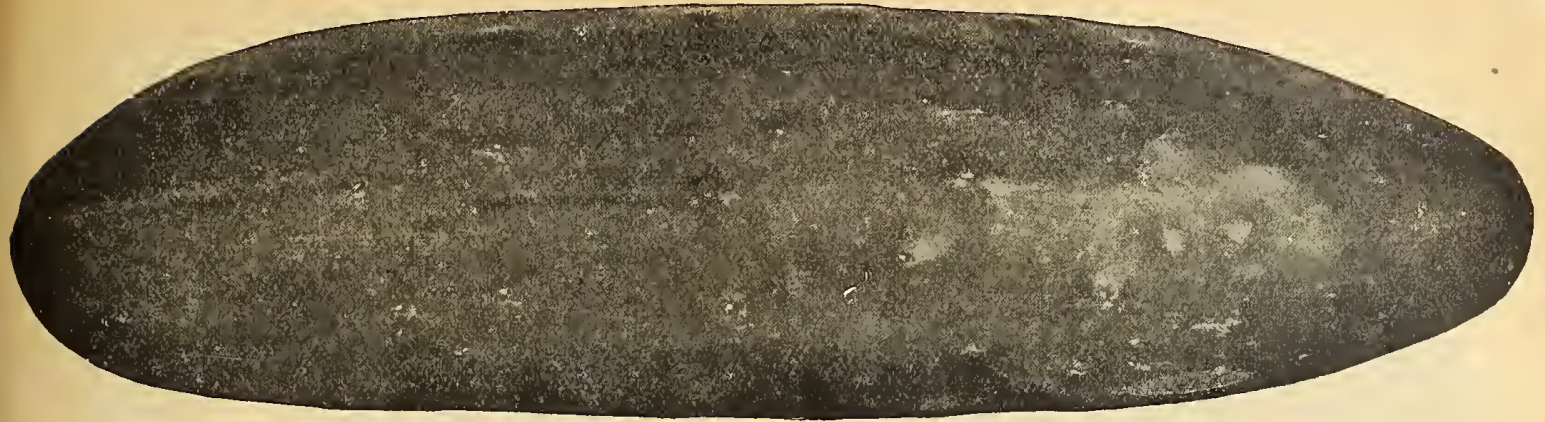

Bolgiano's Famous New Early Fortune Cucumber

Pkts., Ozs. and $1 / 4$ Lbs. Delivered Free.
Parcel Post Rates, sec Page 2.

Culture. For very early, sow in hotbeds upon pieces of sod, or in small pots: they can be readily iransplanted with a gain of about six weeks before they can be sown in the open. Plant out in rich soil when danger of frost is over, or protect by hand glasses, or by paper held down at the corners with earth. For general crops sow in the open as soon as the weather is settled and warm, and every two weeks for a succession. For pickles sow from middle of June to Fourth of July. Sod land, turned over in the Fall; is the best for them. Plant in hills $t$ feet apart, putting shovelfur of well-rotted manure in each hill.

394. Bolgiano's New "Crystal Springs" Cucumber. New 1918 introduction. Extra early, heaviest yielding, continuous bearer. Atractive rich, glossy, deep green color. Deep green to the very tips. Mildew-proof, never shapen fruits or culls. Flesh firm, fine grained and tender. The quality is superb. Most refreshing and delightful flavor. Entirely free from bitterness. Very few seed. Fine for slicing. The ideal Cucumber for either shipping, market or home use. Pkt. 10c. Oz. 15c. 2 Ozs. $25 \mathrm{c} .1 / 4 \mathrm{Lb}$. 45 c. $1 / 2$ Lb. 80c. Lb. $\$ 1.50$. Postpaid.

84. Bolgiano's Early Fortune Cucumber. Full blooded, 84. Bolgiano's Early Fortune Cucumber. Full blooded, as pretty as a picture, and extremely eary, wonderfuly productive, a wodel in shape, of the most inviting and in the world. Pkt. 10c. Oz. 10c. $1 / 4 \mathrm{Lb}$. 25c. $1 / 2 \mathrm{Lb}$. $40 \mathrm{c}$. Lb. 75 c. Postpaid.

17. Bolgiano's "Prosberity" White Spine Cucumber. New introduction. This wonderful new Cucumber will imediately iump into the utmost favor with shippers, market gardeners and private gardeners. It absolutely has no equal; it will bring prosperity to you quick. Pkt. 10c. Oz. 10c. 2 Ozs. 15c. 1/4 Lb. 25c. 1/2 Lb. 40c. Lb. 75c.

135. New Klondike. Terv dark green, 6 or 7 inches long and two inches thick, remains crisp a long time. It is a orand market sort. Pkt. 5c. Oz. 10c. 2 Ozs. 15c. 1/4 is a grand market sort. Pkt. 5c. Oz. 10
Lb. 25c. 1/\%. Lb. 40c. Lb. 75c. Postpaid.

82. Lord Baltimore. The wonderful Dry Weather Cucumber. Dark green. 15 inches long. Fkts. 5c and 10c.
Oz. 10c. 2 Ozs. 15c. 1/4 Lb. 25c. 1/2 Lb. 40c. Lb. 75c. Postpaid.

54. Davis Perfect Cucumber. A very good dark green, wbite spine Cucumber, originated by the same Michigan Market Gardener who originated the Davis Wax Bean. Pkt. 5c. Oz. 10c. 2 Ozs. 15c. 1/4 Lb. 25c. 1/2 Lb. 40c. Lb. 75e. Postnaid.

19. The "Henderson" Perfection White Spine Cucumber. A uniform, beautiful type of Cucumber, of a rich, deep green color, crisp and good flavored. Pkt. 5e. Oz. 10c. 2 Ozs. 15c. 1/4 Lb. 25c. $1 / 2$ Lb. $40 \mathrm{c}$. Lb. $70 \mathrm{c}$.

85. Arlington White Spine. Beautiful in shape, color, and of the finest quality. The fruit is long, cylindrical dark green with very white, crisp and tender flesh of excellent flavor. Ple. 5c. Oz. 10c. 2 Ozs. 15c. 1/4 Lb. $20 \mathrm{c}$. $1 / 2$ Lb. $35 \mathrm{c}$. Lb. $60 \mathrm{c}$.

338. New Century. A fine, new White Spine, 8 to 10 inches in length. The fruits are smooth and regurar, a rich, dark green in color, the blossom end full and round Tbe skin is quite thin and tender, flesh pure wbite and crisp. Pkt. 5c. O\%. 10c. 1/4 Lb. 20c. Lb. 65c.

90. New Extra Early Evergreen, White Spine Cucumber. Prolific dark green. Pkt. 5e. Oz. 10e. 1/4 Lb. 20c. Lbs Gase.

340. Fordhook Pickling. A rery prolific pickling. Pkts. ic and 10c. Oz. 10c. 2 Ozs. 15c. $1 / 4$ Lb. $25 \mathrm{c}$. $1 / 2$ Lb. $40 \mathrm{c}$ I.b. $70 \mathrm{c}$.

95. Improved Jersey Pickle. It is merlium in length, verv shapely, prolific and holds its color. Pkt. 5c. Oz. 10c. 1/4 Lb. 20c. Lb. 65e.
92. New Excelsior Long Green Cucumber. It is a model for size, form and beauty. Deep green color, and an abundant cropper. For table use and pickles. This sort runs so uniform that the Cucumbers look as if they had all been selected. Pkt. 5c. Oz. 10c. 1/4 Lb. 25c. Lb. 70c.

398. Early Green Cluster Cucumber. Most desirable for pickling. Very prolific. Sets in clusters of 2 and 3 for pickling. Very prolific. Sets in clusters of 2 and 3 . Continues long in be
$1 / 2$ Lb. $35 \mathrm{c}$. Lb. 65c.

85. New Extra Long White Spine Cucumber, or Ford Hook Famous. Skin very deep green; flesh green ish white firm and unusually crisp. The plant is a strong grower; leaf large and of a deep green color. The fruit is long (12 to 17 inches), smooth, slim and uniform. Owing to its large, thick, heary leaf it withstands attack of insects. its Northern origin insures hardiness and vigor Pkts. its Northern origin insures hardiness and vigor. Pkts. Lb. $65 \mathrm{c}$.

86. Improved Extra Early White Spine. Produces Cucumbers of finest form and most salable size for shipping purposes. Dark green color. Pkt. 5c. Oz. 10c. 2 Ozs. 15c. $1 / 4$ Lb. 20c. $1 / 2$ Lb. 35c. Lb. 60c.

87. Thomas' Perfection Early White Spine. A selection from the famous Arlington white Spine, $1 \mathrm{t}$ is re garded as far superior to that variety. Pkt. 5c. Oz. 10c $1 / 4$ Lb. 20 c. Lb. 65e.

93. Bolgiano's New Prolific Pickling. Bears fruit from tbe time it first starts until frost. Vines are strong and vigorous, yielding immense quantities of fruit, and remains in a fresh, healthy growing state longer tban any otber sort Skin is very thin, tender, and quite free from toughness when pickled. Plkt. 5c. Oz. 10c. 1/4 Lb. 20c. Lb. 65c.

236. Boston Pickling. Fruit shori, smooth and pointed at each end; light green, a great yielder; one of the best for pickling. Pkt. 5c. Oz. 10c. $1 / 4 \mathrm{Lb} 20 \mathrm{c}$. Lb. $65 \mathrm{c}$.

208. Chicago or Westerfieid Picking Cucumber. Fine for Market Gardeners. Merlium length, pointed at each end, large spine, deep green, very prolific. A fine pickling variety. Pkt. 5c. Oz. 10c. $1 / 4$ Lb. $20 \mathrm{c}$. Lb. $65 \mathrm{c}$.

97. Thorburn's Everbearing. Sets fruit very early and continues to blossom and fruit until killed by frost; good pickler and slicer. Pkt. 5c. Oz, 10c. 2 Ozs. 15c. 1/4 Lb. 20c. 1/2 Lb. 35c. Lb. 65c.

98. Improved Long Green. Pkt. 5c. Oz. 10c. 1/4 Lb. 25c. Lb. $70 \mathrm{c}$

94. Early Frame, or Early Short Green. Desirable for producing pickles of medium size and fine quality Pkt. 5c. Oz. 10c. 1/4 Lb. 20c. Lb. 65c.

518. West India Gherkin. This is the only genuine Gherkin. 1t is small, oval and covered with spines, color light green. Pkts. 5e and 10c. Oz. 10c. 1/4 Lb. 25c. 1/ Lb. 40c. Lb. 75c. Postpaid.

517. Japanese Climbing Cucumber. Used as a beautiful vine and also for its fruit. Pkt. 10c. Oz. 10e. 1/4 Ib. 25c. Lb. 85c. Postpaid.

573. Wild Cucumber. Quickly produces a very luxuriant climbing vine, filled with an abundance of beautifu flowers: the fruit is often used for pickling. Pkt. 10c. Oz. 15c. 1/4 Lb. 25c. Lb. 85c. Postpaid.

342. The New Lemon Cucumber. It has a thin skin, is crisp. tender and sweet. Can be used sliced, whole or as pickles. Pkt. 10c. Oz. 15c. 2 Ozs. 25c. 1/4 Lb. $45 \mathrm{c}$ $\begin{array}{lll}\text { as pickles. Pkt. } 10 c . & \text { Oz. 15c. } \\ 1 / 2 & \text { Lb. 80e. Lb. } \$ 1.50 . & \text { Postpaid. }\end{array}$

38t. Cool and Crisn. This is the earliest and one of the most pralific pickling Cucumbers. The Cucumbers are of a dark color, straight, long, even and slim. They are very tender and crisp. Plkt. 5c. Oz. 10c. 1/4 Lb. $20 \mathrm{c}$
Lb. 65e. 


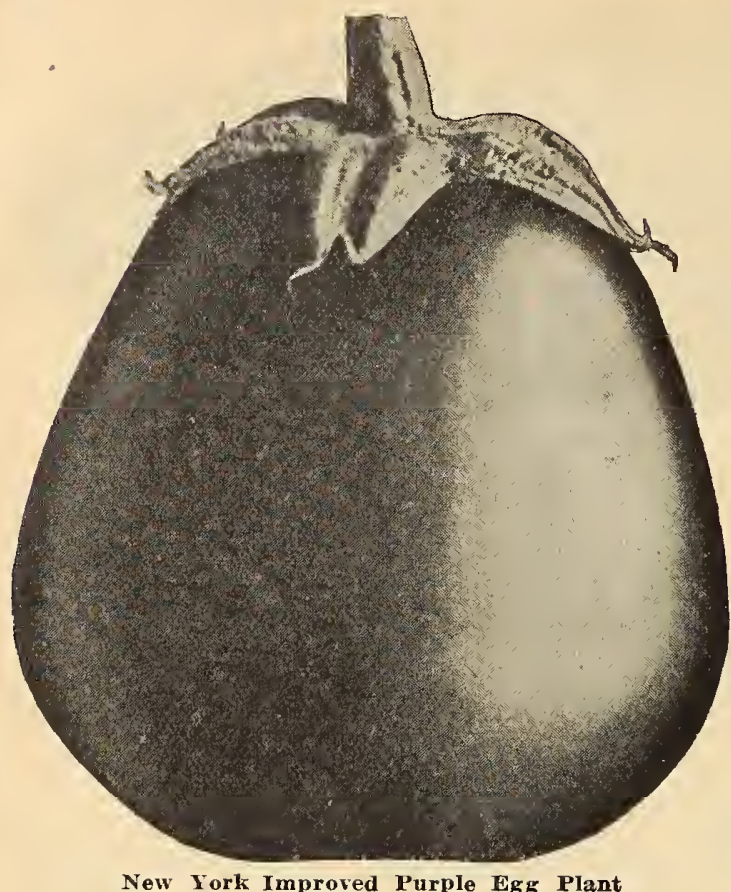

New York Improved Purple Egg Plant

One Ounce wiil Hog Plant Pkts., Ozs. and $1 / 4$
rbs. Delivered Iree

Culture. Sow in hotbcds very early in spring and transplant when 2 inches hign into a second bed or into small pots. If this is not done, thin to 4 inches apart. Do not plant out until weather is perfectly settled and warm. Cool nights or wet weatber will cbeck them. Keep some back in frames for a second planting, in case of weather cbanging unexpectedly. Set cut plants 3 feet by 2 .

100. Bolgiano's Black Beauty Egg Plant. The earliest and best of all large fruited Egg Plants. Pkts. $5 \mathrm{c}$ and $10 \mathrm{c} .1 / 2 \mathrm{Oz}$. 20 c. Oz. 40c. 2 Ozs. 70c. $1 / 4$ Lb. $\$ 1.35$. 1/2 Lh. $\$ 2.40$. Lb. $\$ 4.50$. Postpaid.

99. The Florida High Bush Egg Plant. Holds the fruit well off the ground, resists drought and wet weatber. Fine purple color, very productive. Pkts. 5c and 10c. 1/2 Oz. 15c. Oz. 25c. 2 Ozs. 45e. $1 / 4$ Lb. T5e. 1/2 Lb. $\$ 1.35$. Lb. $\$ 2.50$. Postpaid.

103. Bolgiano's Improved Large Purple Egg Plant. Perfect stock of improved Large Purple Egg Plant-purer, truer, better tball bas ever heen offered before. It bas a handsome shape, a fine, dark, purple color, beautiful form, large size, and is uniform, making it attractive for shipping and market use. Pkts. 5c and 10c. $1 / 2$ Oz. $20 \mathrm{c}$. Oz. 35e. 2 Ozs. 65e. 1/4 Lb. $\$ 1.15$. $1 / 2$ Lb. $\$ 2.15$. Lb. $\$ 4.00$. Postpaid.

101. New York Improved Egg Plant. (Spineless.) A vigorous grower; fruit large, fine, free from thorus, and produce until frost; skin of a ricb purple, flesh white and of a rich flavor. We can higbly recommend tbis Egg Plant. Pkts. $5 c$ and 10c. $1 / 2$ Oz. $20 \mathrm{c}$. Oz. 35c. 2 Ozs. 65c. 1/4 Lb. $\$ 1.15 .11 / 2$ Lb. \$2.15. Lb. \$4.00. Postpaid.

104. New Orleans Egg Plant. Large, dark, purple or New Orleans Market. They are good shippers. Pkts. $5 \mathrm{c}$ and $10 \mathrm{c}$. $1 / 2$ Oz. 15c. Oz. 25c. 2 Ozs. 45c. 1/t Lb. 75c. 1/2 Lh. $\$ 1.35$. Lib. $\$ 2.50$. Postpaid.

556. New Jersey Improved Large Smooth Egg Plant. Pkts. $5 \mathrm{c}$ and $10 \mathrm{c}$. $1 / 2$ Oz. $20 \mathrm{c}$. Oz. 35c. 2 Ozs. 65c. $1 / 4$ Lh. $\$ 1.15 .1 / 2$ Lb. \$2.15. Lb. $\$ 4.00$. Postpaid.

One Ounce Will Produce About 5,000 Plants. Kale Pkts., Ozs. and 1/4 Lbs. Delivered Free.

Culture. The Kales are more hardy than Cabbage, make excellent greens for Winter and spring use, and are improved hy frost. Sow from May to June, and cultivate the same as Cahhage. For early Spring use sow in September, and protect during. Winter. Some of the varieties are so bardy that the green leaves may be dưg out from under the snow in Winter and be used for greens.

113. Bore Cole or Kale. Hardy Winter Spargel Kohl. The most salable, delicious and tender of all Winter Kales. About Baltimore it is sown in May, and transplanted like Cabbage to stand over Winter. It is taller tban the extra dwarf varieties, and when the leaves are stripped or fall off, new tender leaves quickly grow out. Then they are again stripped off and used for marketing. It will stand tbe coldest Winter. Besides being a delicious vegetable, it has always been an exceptionally profitable crop,
bringing money during Winter montbs when most all vegetables are scarce. Sold out immediate delivery. Write for prices Spring Delivery.

112. Extra Dwarf Green Curled Scotch, or Norfolk Kale. One of the best Kales for Spring sowing in the North; tbe principal sort grown Soutb for Northern markets; hardy, and will remaiu over Winter where temperature does not go below zero. green color, beautifully curled and prodnced in great abundance. Pkts. 5c and 10c. gz. 20c. $1 / 4$ Lb. 60c. $1 / 2$ Lb. $\$ 1.10$. Lb. $\$ 2.00$.

108. New Imperial, Very Curly, Long Standing Kate. Beautifully curled and crimpled sort; strong, vigorous habit, perfectly hardy, bright green color; very attractive in appearance; superior to all late sorts; will stand longer witbout shooting to seed tban any other variety. Pkts. 5c and 10c. Oz. 10c. $1 / 4$ Lb. $20 \mathrm{c}, 1 / 2 \mathrm{Lb}$. 30c. Lb. 50c.

351. Spring or Smooth Kale. Ahardy, quick growing, smootb learedrariety. The best for Spring sowing,but largely sown in the Fall, making greens earlier tban the $W$ nter varie-ties. Pkt. 5c. Oz. 10c. 1/2 Lb. 15c. Lb. $25 \mathrm{c}$.

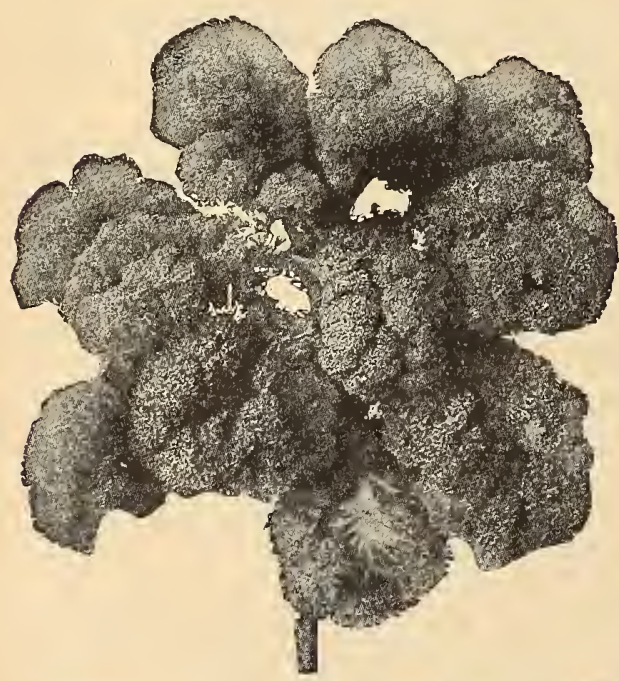

109. Curled German Kale. Hardy; stands the frost of our severest Winters; grows rapidly, dwarf babit, heautifully curled. Pkts. 5e and 10c. Oz. 10c. $1 / 4$ Lb. 20c. $1 / 2$ Lb. $30 \mathrm{c}$. Lb. $50 \mathrm{c}$.

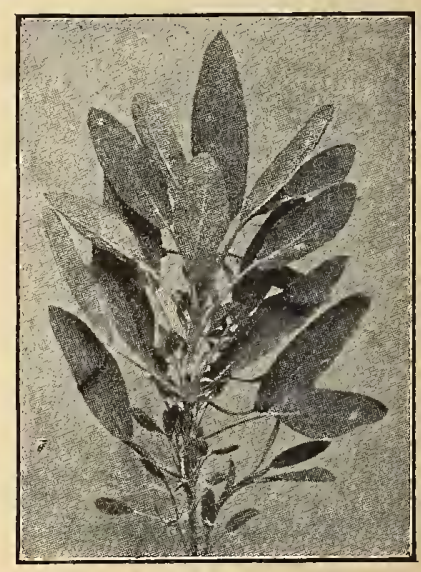

Sage

110. Siberian Curled Kale. Tbe green leaves are very large and comparatively plain in the center, but beavily curled on tbe edge. It is a fast grower, extremely bardy and will stand longer in tbe Spring without bolting than any other variety. Pkts. 5c and 10c. Oz, 10c. 1/4 Lb. 20c. $1 / 2$ Lb. 30c. Lb. 50c.

$1 / 2$ Lb. $30 \mathrm{c}$. L L. 50c. 512. New American, Extra Curked Long Standing Kale. Of a beau-
$t$ iful green color. Pkts. 5c and 10c. Oz. 10c. $1 / 4$ Lb. 20c. 1/2 Lb. 30c. Lb. 50c.

\section{Herbs-Sweet, Medicinal and Pot}

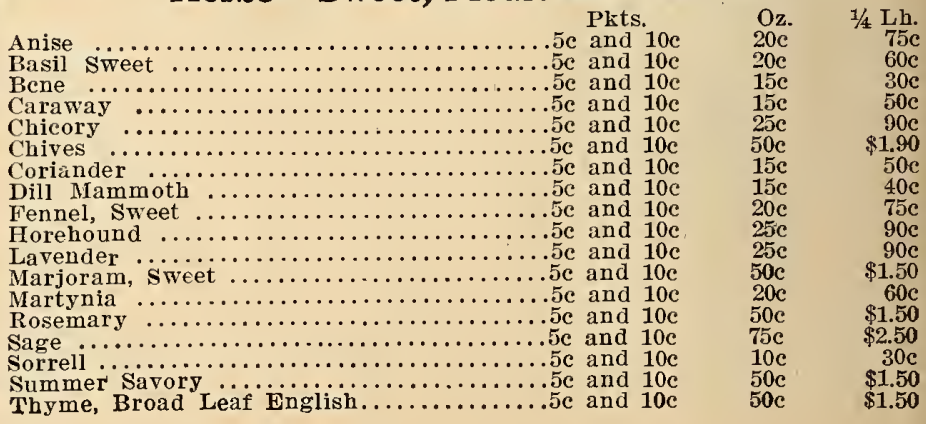

Bolgiano's Hard.y Winter Bore Cole or Kale Thyme, Broad Leaf English..............5e and 10c 50c $\$ 1.50$ 


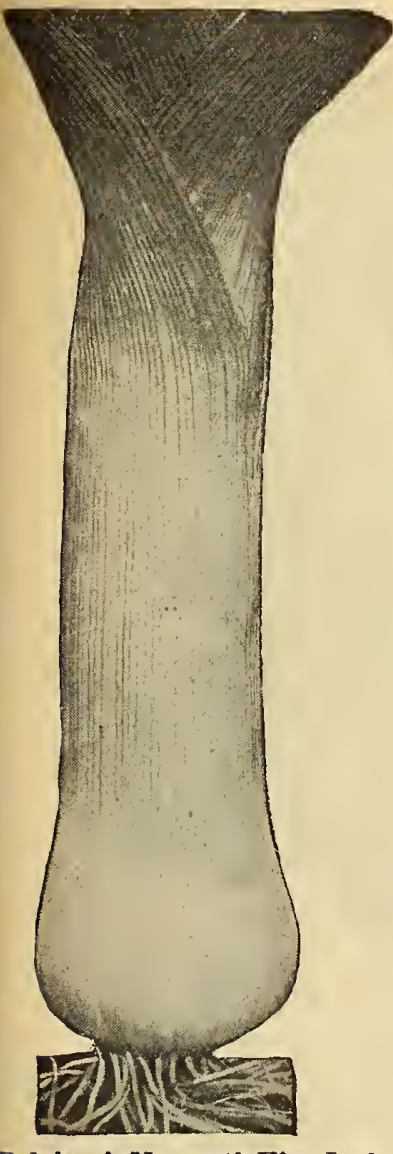

Bolgiano's Mammoth King Leek

1 oz. to 150 feet of row. Hindive Parcel Post Rates, see Page 2.

106. Bolgiano's New Self-Blanching Endive. A perfect self-blanching curled Endive, beautiful and gracefur in shape, most attractive, perfect color, shading from a large, rich, golden heart to the outer leaf of emerald green. Pkts. 5c and 10c. Oz. 15e. 2 Ozs. 25c. $1 / 4$ Lb. 40c. $1 / 2$ Lb. 70c. Lb. $\$ 1.25$.

107. Green Curled Endive. Much better than the common varieties. An attractive and ornamental regetable. Pkts. 5e and 10c. Oz. 10c. 1/4 Lb. 25c. 1/2 Lh. 40c. Lb. $75 \mathrm{c}$.

\section{Leek}

Culture. Sow early in April in drills 1 foot apart and 1 inch deep. When plants are 6 to 8 inches high transplant in a deep, rich soil in rows 12 inches apart and 6 inches in the rows as deep as possible, so that the neck mas be covered and blanched; draw the earth to them as they grow.

\section{Bolgiano's Famous Mammoth King Leek}

114. This stock we have by years of selection built uxp until it has become to those who use it a pleasure to grow and a profit, too. It has a handsome form, is very mild, agreeable in flavor, grows to double the size of ordinary varieties, is pure white, has attractive, dark-colored leaves, is stout in hahit and hardy. The edible part is 8 to 15 inches long and 3 to 5 . inches in diameter. It is without exception the largest and best Leek ever placed in the hands of the grower. Pkts. 5c and 10c. Oz. 25c. 2 Ozs. $45 \mathrm{c}$. Leek erer placed in the hands of the
$1 / 4$ Lb. $75 \mathrm{c}$. $1 / 2 \mathrm{Lb}$. $\$ 1.35$. Lb. $\$ 2.50$.

546. Monstrous Carenton or Scotch Champion. Very large, hardy and produetive: popular for market. Pkts. 5e and 10c. Oz. 25c. 2 Ozs. 40c. $1 / 4$ Lb. 65c. 1/2 Lb. $\$ 1.20$. Lb. $\$ 2.25$.

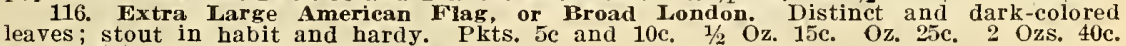
leaves; stout in habit and hardy.
$1 / 4$ Lb. 65 c. $1 / 2$ Lb. $\$ 1.20$. Lb. $\$ 2.25$.

Try Mustard cooked like spinach it is delicious.

In Lots of 5 Lbs. Deduct 5e Per $\mathbf{L b}$.

MIIstard One ounce will sow

Pkts., Ozs. and $1 / 4$ Lbs. Delivered Free.

203. Southern Giant Curled The true curled leaf variety, sweet flavored, pungent and surculent; used for early salad. Pkt. 5c. Oz. 10c. 1/4 Lb. 20c. 1/2 Lb. 30c. Lb. 50c.

204. Ostrich Plume Mustard or Fordhook Fancy. Desirable and ornamental. It is distinct from any other variety. The plants are of vigorous growth, and the beautiful dark green, pungent leaves curve outwardly like a fine ostrich plume. The edges are as thoroughly curled and laciniated as the best double curled Parsley, making the leaves equally desirable for garnishing. So attractive is the habit of growth and the feathery effect of the finely fringed leaves that this plant is quite worthy of a place in the garden effect of the finely fringed leaves that this plant is qurite worthy of a place in the garden
as an ornamental border plant. Pkts. 5c and 10c. Oz. 10c. 1// Lb. 20c. 1/2 Lb. 30c. Lb. 50c.

527. Black or Brown Mustard. Pkts. 5c and 10c. Oz. 10c. 1/4 Lb. 25c, 1/2 Lb. 40c. Lb. $75 \mathrm{c}$

539. White Mustard. Plsts. 5c and 10c. Oz. 10c. 1/4 Lb. 25c. 1/2 Lb. 40c. Lb. 75c.

\section{Okra or Gumbo Pkts., Oas. and ${ }^{1 / 4}$ Lbs. Delivered Free.}

198. Perkins' 198. Perkins Mammoth Long-Podded okra. Pods shoot out from the stalk within heiree inches of the ground and the whole 9 to 10 inches long wery slim to its extreme hard. It is much sought by canners. Pkts. 5c. Oz. 10c. $1 / 4 \mathrm{Lb}$. 15̌c. Lb. 35c. $10 \mathrm{lbs}$. at $30 \mathrm{c}$ 1b.

201. Bolgiano's Imperial Dwari Short Podded Okra. It has a dwarf, shapely, dense pod, of an attractive pea-green color. The flavor is exceptionally rich. Our home canners willingly pay 20 to 25 cents per box more than any other sorts would bring. Pkt. 5e. Oz. 10c. $1 / 4$ Lb. 15c. Lb. 40c. $10 \mathrm{Lbs}$. at $35 \mathrm{c}$. ib.

200. White Velvet okra. The pods of this distinct and beautiful new okra are much longer, perfectly smooth, never prickly. Pkt. $5 \mathrm{c}$. Oz. 10c. $1 / 4$ Lh. 15e. Lb. 35c. 10 Lbs. at 30c ib.

\section{Nasturtium}

Nasturtium of all varieties are useful for furnishing tender seed-pods which make delicious pickles. The seeds for lickling shourld be gathered while green and with a portion of the stem attached. Pick them over and place in a jar until flled; then cover them with cider vinegar that
199. Dwarf Green Prolifie Density Okra or Gumbo. Its green pods impart fine flavor and consistency to soups and stews, besides being palatable when steved and served as a dish of 10 Lbs, at $30 \mathrm{c}$.

202. Lady Finger okra. The plants are uniform in growth and flowers make a pretty sight. The plants produce long, tender pods of fine, round form, white and smooth. Pkt. 5e. Oz, 10e. 1/1/2 Lb. 15e. Lb. 35e. 10 Lbs. at $30 \mathrm{c}$. $1 \mathrm{~b}$.

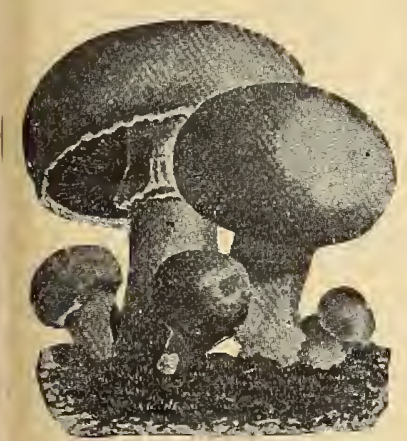

Mushrooms has been brought to the boil and is still warm, to keep for Winter use.

Dwarf Mixed. Pkts. 5e and 10c. Oz. $15 \mathrm{c}$. Lb. 35 c. Lb. $\$ 1.10$.

Tall Mixed. Pkt. 5c. Oz. 15e. 2 Ozs. 20c. 1/4 Mushroom Spawn

Culture. Mushrooms may be grown in cellars, under benches in greenhouses, or in sheds wherever the temperature of 50 degrees can be kept up during the Winter. The beds should be made from Norember to February, according to the time the Mushrooms are wanted, and it requires about two months for them to begin bearing. Secure fresh horse dung, free from straw and litter, and mix an equal bulk of loam from an old pasture with it. Keep this under cover, taking care to turn it every das to prevent it from heating, until the pile is large enough to make a bed of the required size. Three or four feet wide, eight inches deep and any length desired are the proper proportions for a bed, but this may be vuried. Prepare the mixture of loam and manure, making the bed in layers and pounding down each with the back of a spade. Leave this to heat through for a few dass, and as soon as the heat subsides to 90 degrees make holes in the bed about a foot apart each war, into which put pieces of spawn 2 to 3 inches in diameter: fill up the hole with compost. and at the expiration of a week or 10 days the spawn will have thoroughly diffused itself through the bed. Spread laver of soil over the heap to the depth of 2 inches, and cover with 3 or 4 inches of hay, straw or litter. Examine bed often to see that it does not get dry. Take special care, however, when water is given that it be at a temperature of 100. One brick to a bed 6 feet squrare. $221 / 2 \mathrm{c} ; 25$ bricks at 20c; 50 to 100 bricks at $18 \mathrm{c}$ each; 10 bricks at Imperial Dwar 


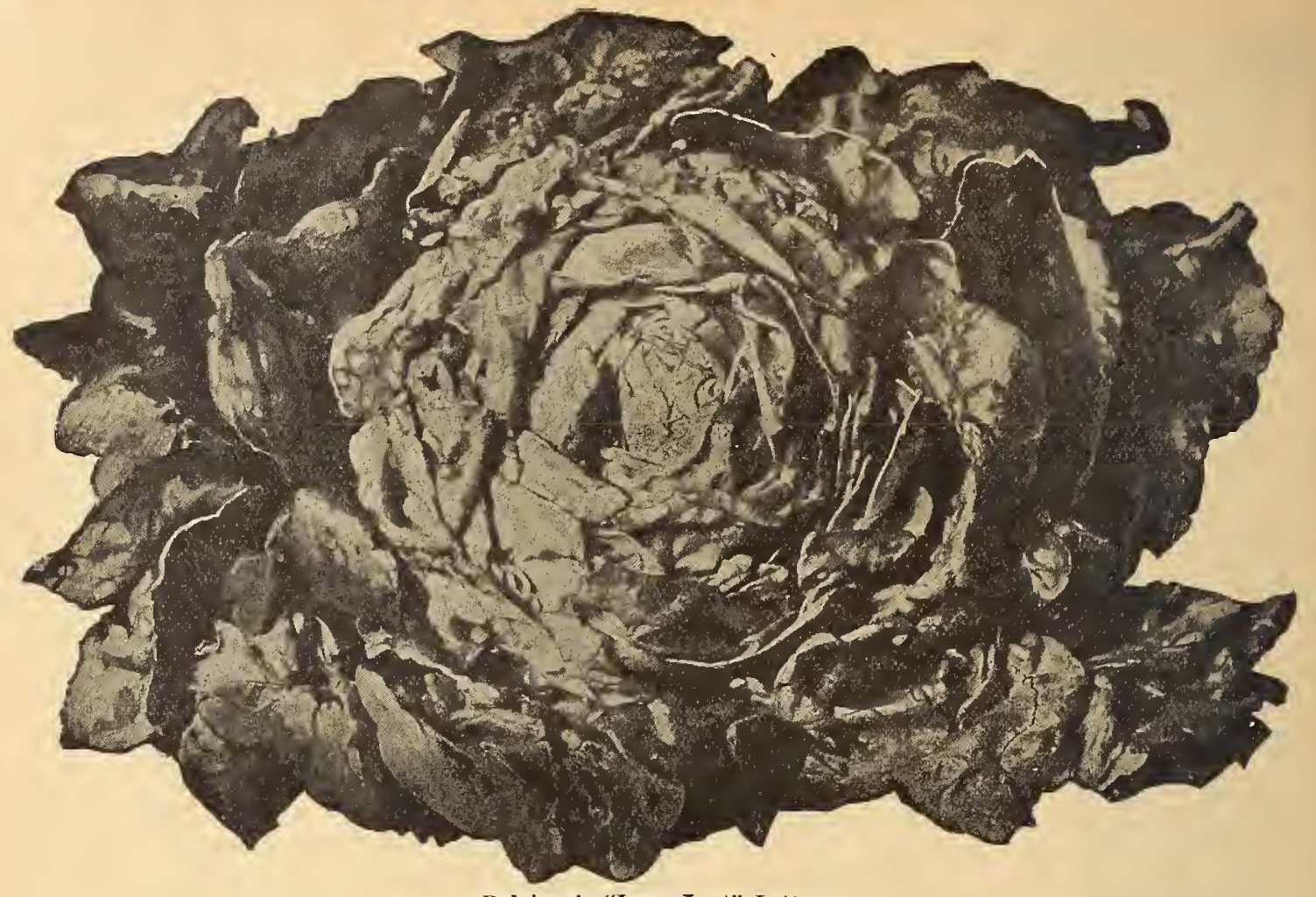

Bolgiano's "Long Lost" Lettuce

\section{Lettuce}

Cnlture. For early Summer use, sow in hotbeds in March, sowing every two weeks for succession. Transplant the young plants to rows 2 feet apart and 8 to 12 inches apart in row. For Winter use, sow in August, transplant to frames: and for this purpose the early heading varieties, such as the Millionaire Lettuce, are best arlapted. The Cos varieties require to be tied up for a few days in order to properly blancb them.

\section{Earliest Varieties}

380. "Long Lost" Lettuce. Produces large, extremely solid, compact cabbage heads. It is a reliable sure header
and is very hardy. It stands the cold. It will Winter and is very hardy, It stands the coln. It nill winter has both shipping and eating qualities, decidedly buttery in flavor, sweet and tender. of a solid, bright, attractive green, never spotted or brownish in any part. As a shipper "Long Lost" Lettuce far surpasses every other Lettuce, including the Big Boston. Supply rery limited. Pkts. 10c and $25 \mathrm{c}$. $1 / 2 \mathrm{Oz}$. 25c. Oz. 50c. 2 Ozs. 80c. $1 / 4$ Lb. $\$ 1.40$

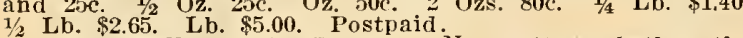
193. "Bully Good" Lettuce. No matter whether the market price is up or down, there is always a market for "Bully Good" Lettuce. Those fine, large, solid heads-a full busliel market box is barely large enough to hold 18 of them-of a bright, rich, exquisite green; With a furl solid, ricb, golden yellow heart closely folded; crisp as ice; with a mild, delicious "favor, do you wonter we have named this grand cettuce "Bully Good. She market Gardener big check from the Northern Cities and the Amateur Gardener with bis neighbors beat to a standstill. Every one wbo grows for Market or eats "Billy Good" Letturce will cheerfully admit it is worthy of its name. Pkts. 5c and 10c. Oz. 15c. 2 Ozs. 25c. 1/4 Lb. 40 c, $1 / 2$ Lb. 70c. Lb. $\$ 1.25$ Postpaid.

131. "Best of All" Lettuce. A sure cropper, Spring, Summer, Fall or Winter. Pkts. $5 \mathrm{c}$ and $10 \mathrm{c}$. Oz, 15c. Ozs. 25c. $1 / 4$ Lb. 40c. 1/ Lb. 70c Lb. \$1.25. Postpaid.

156. Big Boston Lettuce. Bolgiano's Famous Stock. Big Boston Lettuce is the most valuable Lettrce in cultiration; its excellent qualities have made it tbe most popular and most extensively used Lettuce in the world. It can be grown in the open ground for summer or Fall, in frame for Spring or forced cool in greenhouses for Winter use, producing under each condition grand, large, buttery rellow heads, filled with sweet, crisp, tender, beautifully blanched leaves. Stands long without going to seed; has few outer leaves and makes a large, attractive plant, Big Boston Letturee is specially adapterl to cool, open ground culture. Our stock of this famous Lettuce is the finest in the World. Pkts. $5 \mathrm{c}$ and 10c. Oz. 10c. 2 Ozs. 15c. 1/4 Lb.
25 c. $1 / 2$ Lb. 40c. Lb. 75 c. Postpaid.

137. Black Seeded Tennis Ball or Boston Market. One of the very best for either forcing or early out-door planting. Plants good size. leaves are of good substance and of attractive, dark green color. Heads are solid, crisp and tender. Pkts. 5e and 10c. Oz. 10c. 2 Ozs. 15c. $1 / 4 \mathrm{Lb} .25 \mathrm{c}$. Lb. 75
155. New Lettuce, "Unrivaled." An improvement on the Big Boston Letture, posscssing earliness, large size, attractive color, etc. It can be sown almost the whole year around: it resists the Summer heat, is crispy and solid. Pkts. 5c and 10c. Oz. 10c. 2 Ozs. 15c. 1/4 Lh. 25c. Lb. 75c. Postpaid.

150. Millionaire Lettuce. Unquestionably the Earliest and far better than any other extremely early large beading Lettuce. A Lettuce fit for a king. Pkts. 5c and 10c, $1 / 2$ Oz. 10c. Oz. 15c. 2 Ozs. 25c. 1/4 Lb. 40c. 1/2 Lb. 70c. Lb. \$1.25. Postpaid.

352. May King. A handsome, light green, heading variety of medium size and excellent quality. ourt-doors the heads mature exceptionally early, attaining a size suitable for use before other sorts, and often the edges of the outer leaves have a brownish tinge. The plant is very compact for so large a head. It is very satisfactory also for forcing under glass. Pkts. 5c and 10c. Oz. 10c. 2 Ozs. 15c. $1 / 4$ Lb. $25 \mathrm{c}$. $1 / 2$ Lb. $40 \mathrm{c}$. Lb. $75 \mathrm{c}$

122. Improved White Loaf Lettuce. After the most carefur cultiration and rogueing, $\pi^{\circ}$ hare established the truest and most uniform strain of improved White Loaf Lettuce. It is planied largely in the Fall and allowed to remain in the open ground all winter. In tbe earliest Spring it quickly forms most delicious, large, light-colored Lettuce heads. As a frame Lettuce it bas no equal, often 18 heads have brought $\$ 2.50$. wholesale. If planted in early Spring, it quickly forms heads and can be brought to mar ket long before other Lettuce. Pkts. 5c and 10c. Oz. 10c 2 Ozs. 15c. 1/4 Lb. 25c. $1 / 2$ Lb. 40c. Lb. 75c. Postpaid.

126. New Early Spring Lettuce. In the Early Spring months this splendid Lettuce prodinces large cabbage-like heads. wbicb are uniform, tender, crisp and sell at highest possible prices. Our most critical Market Gardeners, year after year, hank on this Lettuce. It is also good for late Summer sowing to produce Fall Head Lettuce. Pkts. 5c and 10c. Oz. 10c. 2 Ozs, 15c. 1/4 Lb. $25 \mathrm{c}$. i/2 Lh. $45 \mathrm{c}$ Lb 85e Postpaid

399. Burpee's Wayahead Lettnce. Shows a remarkable combination of earliness, firm heading cbaracter, handsome appearance and fine quality. Both in cold-frames early in the Spring and in the open ground in Spring, Summer and early Fall months, it has proven to be one of the earliest and surest heading of all early Lettuces. The outer leares are a light green, rith the inner head firmly blanched to a rich buttery rellow: Retains its good quality throughout the season and stands longer without going to seed than many other early varicties. Pkts. 5e and 10\%. Oz. 15c. 1/4 Ib. 40c. 1/2 Lb. 70c. Lb. \$1.25. Postpaid. 


\section{Heading Lettuce}

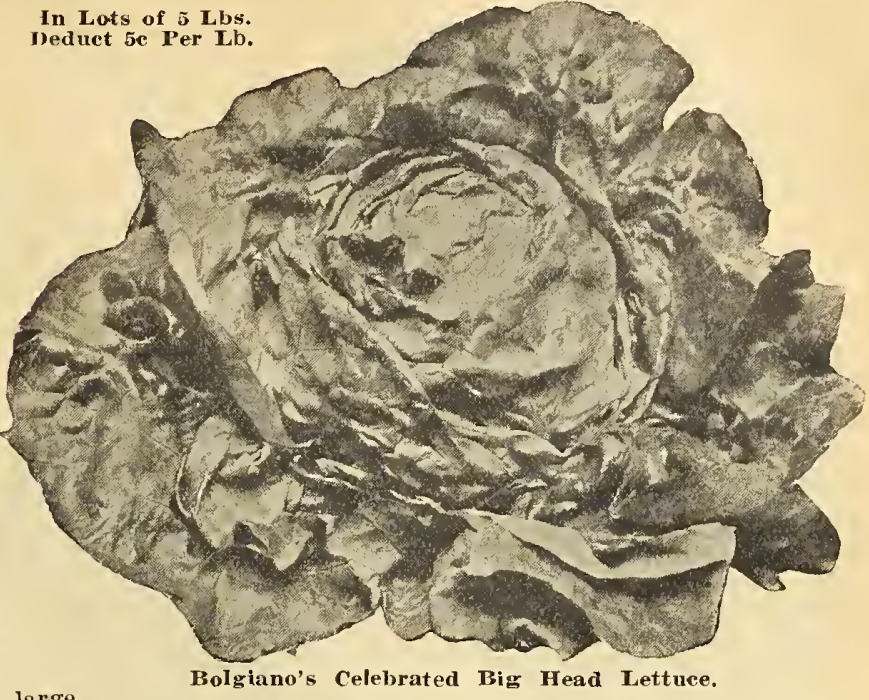

400. Simon's Cabbage Head. Tbis is one of the finest varieties of Lettuce erer offered, and is superior to Big Boston in many ways. It does not scald in the beart and does not turn red from cold. It is just as large and a: firm as Big Boston, and is a little lighter in color. Pkts. 5 and 10c. Oz. 15c. 1/1 Lb. $30 \mathrm{c}$. 1/2 Lb. 55c. Lb. $\$ 1.00$. Postpaid.

124. Bolgiano's Cclebrated Big Head Lettuce. Its beautiful form and color attract the attention of expert growers. It forms a compact head; bas no core, but a iender, colden heart. As a shipper it is unexcelled, commands the stands the Summer heat; always has a crisp mild flavor. Pkts. 5c and 10c. Oz. 15c. 1/4 Lb. 30c. Lb. \$1.00. Postpaid.

118. Bolgiano's "Gold Prize." 1. Handsome, very large, solid head. 2. Will not rot in the stem. 3. Outer leaves a beautiful lightgreen color. 4. Inner head large. round, creamy, tenuler and crisp.5. Very slow to go to seed. 6. Pronounced by experts to . ebrated Big Head Lettuce. Not tougb like Defiance Let tuce. Pkts. $5 \mathrm{c}$ and 10c. Oz. 10c. $1 / 1 \mathrm{Lb}$. 25c. Lb. $85 \mathrm{c}$

134. Mammoth Black Seeded Butter. Pkts, 5c and 10c. Oz. 10c. 1/4 Lb. $25 \mathrm{c}$. Lb. T5c.

153. Baltimore Cabbage Lettuce. Pkts. $5 \mathrm{c}$ and $10 \mathrm{c}$ Oz. 10c. 1/t Lb. 25c. Lb. 75c.

465. Bolgiano's New Golden Heart. Pkt. 5c. Oz. 10c $1 / 4$ Lb. $25 \mathrm{c}$. Lb. S5.

466. Salamander Improved. Pkt. 5c. Oz. 10c. 1/ Lb. $25 \mathrm{c}$. Lb. $75 \mathrm{c}$

467. Royal Cabbage Lettuce. Plkt. 5c. Oz. 10c. 1/4 Lb. 25c.

\section{Solid Crisp Headed Lettuces}

142. Bolriano's New "Frozen North" Lettuce. Tbis delicious new crisi bead Lettuce will delight our cus tomers. Pkts. 5e and 10e. 0\%. 15e. 2 Ozs. $25 \mathrm{c} .1 / 4 \mathrm{Lb}$ 40c. $1 / 2$ Lb. 70c. Lb. $\$ 1.25$. Postpaid. 132. Grand Rapids. Iinely curled or fringed edges. Its delicious quality and handsome appearance makes it most popular. Pkts. $5 \mathrm{c}$ and 10c. Oz. 10c. 1/4 Lb. 25c. $1 / 2$ Lb. 40c. Lb. 75c. Postpaid.

143. Denver Market. Large, conical beads of finest quality; leares light golden green, beautifull savoyed. Pkts. $\bar{c}$ and 10e. Oz. 10c. 1/4 Lb. 25c. 1/2 Lb. 40c. Lb. $75 \mathrm{c}$. Postpaid.

349. "Brittle Ice" Lettuce. Large, brittle, mild flavored, crisp heading Oz. 10c. 1/4 L.b. 25c. 1/2 Lb. 40c. Lb. 85 c. Postpaid.

350. "Iceberg" Lettuce. The heads are large, crisp, solid and tender. Pkts. 5c and 10c. Oz. 10c. 1/t Lb. 25c. 1/2 Lb. 45c. Lb. 85c. Postpaid.

145. Hanson. Grows to large size and is uniformly sule beading. Hears very solid and beautifully blanched; crisp, mild and tender. Pkts. 5c and 10c. Oz. 10c. $1 / 4$ Lb. 25 c. $1 / 2$ Lb. 45c. Lb. 80c. Postpaid.

147. Black-Seeded Simpson. Very large, finely fringed. Pkts. 5e and 10c. z. 10c. 1/4 Lb. 25c. 1/2 Lb. 40c. Lb. 75c. Postpaid.

brow. Early-Prize Head. (Brown Cabbage.) Large, loose heads, tinged with

Pkts. 5e and 10c. Oz. 10c. 1/4 Lb. 25c. Lb. 75 c.

tender Early Curled Simpson or Silesia Lettuce. Mlakes large bunches of crisp tender, curly leaves; tbis Lettuce is the most popular of all for family gardens. 464, Crisp As Iee. Pkt. $5 \mathrm{c}$. Oz. 10c. 1// Lb. 25c. Lb. $85 \mathrm{c}$.

\section{Cos or "Celery" Lettuce}

The Lettuce called Salad Romaine is of distinct, upright growth and esteemed for its fresh crispness and mild favor during the summer and in
warm climate.

339. Eclipse or "Express" Cos. The most olwarf and earliest of all. The planis grow stiffy prect, only six or seven incbes in beight. Tbe interior leares are almost mure wbite, very crisp, and mild in flavor, even in lot eather. Pkts. 5c and 10c. Oz. 10c. 2 Ozs. 15c. 1/2 Lb. 15c. Lb. Soc. Postluaid.

123. Paris Self-Folding, or Trianon White cos. Grows to a very large size, producing long-pointed compact buncbes. Pkts. $5 \mathrm{c}$ and $10 \mathrm{c}$.

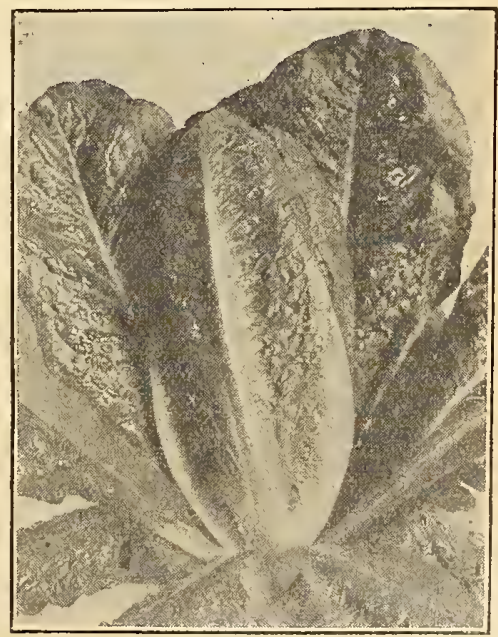
Paris Self-Folding White Cos or Celery Letereo 


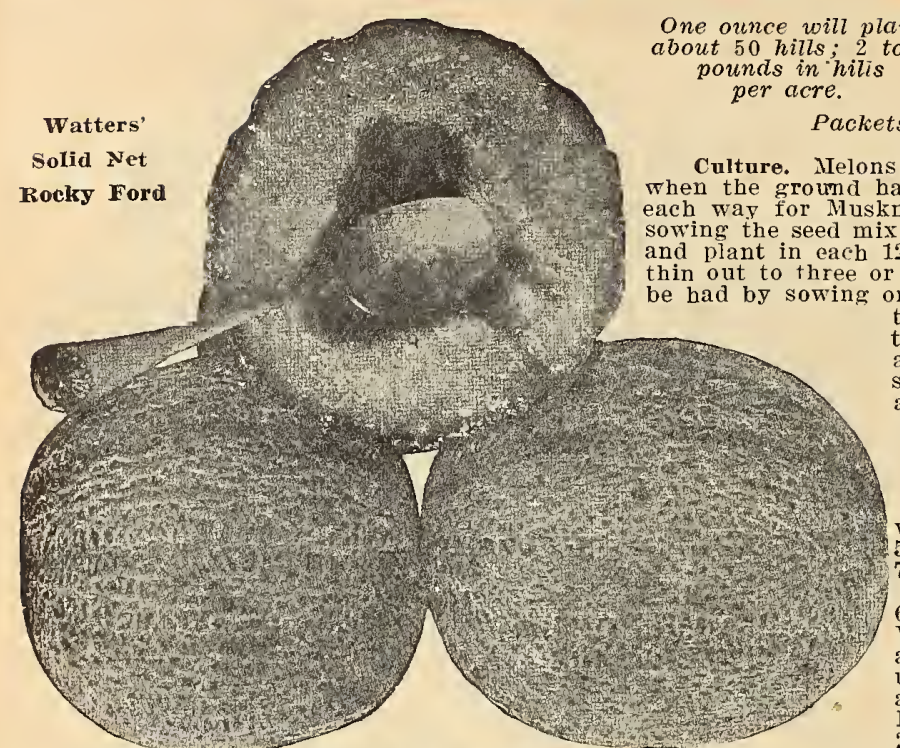

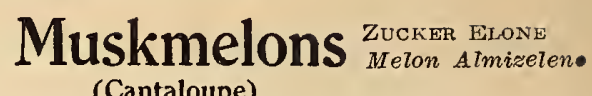

\section{Packets, Ounces and $1 / 4$ Los. Delivered Free.
Parcel Post Rates, see Page 2.}

Culture. Melons thrive best in a light, rich soil. Plant early in May, when the ground has beco 8 to 10 feet for watermelons. Previous to sowing the seed mix a few shovelsful of well-rotted mannre in each hill, and plant in each 12 to 15 seeds; after all danger of the bngs is over, thin out to three or four plants per hill. A few hills for early use may on pieces of sod in a hotbed, and when warm enough
transplant to open ground. Melon vines are subject to the same destruc tive insects and fungous foes as are Cucumber andsquash vines. Early and repeated spraying with Bordleaux Arsenate of Lead Mixture is always advisablefor these crops.

In Lots of 5 Lbs. or More Deduct $5 c$ Per Lb.

\section{Green Fleshed Varieties}

16. "Junior" kocky Ford. A little larger, two weeks earlier, twice as prolific as Rocky Ford. Pkts. 70c. Lb. $\$ 1,25$. Postpaid.

50. Honey Dew. The new Melon. Arerage size 6 inches in diameter and 7 to 8 inches in length. Weight averages 8 to 10 pounds. The skin is smooth and the pind, though thin, is very tough. Will keep until Christmas. Creamy yellow when ripe. Flesh Is a good shipper. Pkts. 5c and 10c. Oz. 15c. 2 Ozs.

157. Thoroughbred "Rocky Ford" Cantaloupe. Thoroughbred Stock. Bolgiano's Trustrorthy Stock. The finest in the world. Color of rind in erevices and unions light ship long distance. lind very tough. When cut, meat light green, changing very slightly toward gold near the center. Fine grained, firm and of high quality ; very spicy and sweet; fesh rery deep. leaving a triangular seed cavicy seed held in three lobes; abundant yielder, having produced "Junior" Rocky Ford, but continues a long time in bearing. Last, but not least, it is an excellent shipper. Pkt.

127. Bolgiano's "Ioney Sweet" Cantaloupe. Juicy, light green flesh, entirely stringless, especially luscious, tender, melts in the mouth, as sweet as honey. Plant same time you would any other melon. When the under take off. They can be laid in sand and covered with straw. being careful not to allow them to touch each other. In this way they can he kept until Christmas. Pkt. 10c. Oz. 15c. $1 / 4$ Lb. toc. $1 / 2$ Lb. 70 c. Lb. $\$ 1.25$. Postpaid.

160. Extra Ear'y Hackensack. Will weigh from 10 to 12 pounds, delicions flavor. Plits. 5c and 10.

161. Netted Gem. Extra earlv, weight 1 to $11 / 1$ pounds fine. Pkt. 5c. Oz. $10 \mathrm{c}$. 1/4 Lb. $20 \mathrm{c}$. 1/2 Lh. 35c. Lb. 60c. 166. Anne Aru Oz. 10e. 1/4 Lb. 20c. 1/2 Lb. 35c Lb. 65e. 333. Aeme or Baltimore. Popular, large, fine flavored,
Pkts. 5c and 10c. Oz. 10c. 1/4 Lb. 20c. 1/2 Lb. 35c. Lb. 6.jc.

\section{Orange Fleshed Varieties}

51. Nelting Gold Rocky Ford Cantaloupe. Simply the most delicious Cantaloupe that was ever eaten. The sweet eating Cantaloupe in the world and a splendid, profitable shipper. Pkts. 5c and 10c. Oz. 15c. 2 Oz. 25c. 1/4 Lb. 40c. $1 / 2$ Lb. 70c. Lb. \$1.25. Postpaid.

574. Salmon Fleshed Eden Gem. Outward appearance is identical with the Eiden Gem, but a trifle more uniform in size; it is the best long-distance shipping Rocky Ford strain, with a new delicious flaror and color of flesh. One of the closest netted of all melons. It is unequaled in hardiness, prolificness and disease resistance It originated hardiness, prolificness and disease resistance It originated The color is almost invariably salmon, if cut at the right stage Surpply of seed very limiled. Pkts. 5c and 10c. Oz. 10c. 1/4 Lb. 20c. 1/2 Lb. 35c. Lb. 65c.

548. Burrell's Gem. The fruit is of good size, handsome appearance and fine flavor. The skin is a rich, dark ored flesh; sweet, tender. Plits. 5c and 10c. Oz. 10c. 1/1 Lb. 20c. $1 / 2$ Lb. 35c. Lb. 60c. Postpaid.

164. Paul Bose. The fruits are nearly round, ribbed and hcavily netted. The flesh is thick, of rich, deep orange color, and ripens close to the rind, with small seed cavity.
It is an excellent shipper. Plats. $5 \mathrm{c}$ and $10 \mathrm{c}$. 1/4 Lb. 20c. $1 / 2$ Lb. 35̄. Ll. 6

162. Orange-Fleshed osage. The fruits are larger than those of the Emerald Gem: nearly round in form, but having the same distinct dark green skin with lighter bands between the libs, and thick, firm, orange flesh of fine

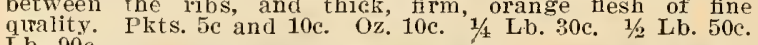
Lb.

Emerald Gem. The melons are about the size of
The flesh is of a beatiful salmon color and Netted Gem. The flesh is of a beautiful salmon color and is peculiarly crystalline in appearance, the flavor is sweet $1 / 4$ Lb. 30c. Lb. $90 \mathrm{c}$.

207. Watters' Improved solid Net kocky Ford Cantaloupe. This is the earliest strain of Rocky Ford Cantalompes. The meat is light green, spicy and sweet. The heavy gray netting is closely laced. Pkts. $5 \mathrm{c}$ and $10 \mathrm{c}$.

401. Delicious Gold-Lined Rocky Ford Cantaloupe. This strain of the Eden Gem type is the result of several rears' selection by one of the most progressive farmers of Rocky Ford, Colo. Shape is ideal, very slightly oval, no ribs, and it is heavily netted over the entire melon. The bloom button is small and flesh as thick at the end as elsewhere. The melon is thick meated. fine grained and sweet; color, green, with a gold margin next to the seed cavity. Uniform shape, size and very swperior quality. Its flesh is attractive and elicits favorable comment when served. Plits. 5c nd 10c. Oz. 10c. 1/4 Lb. 25c. 1/2 Lb. 40c. Lb. 75c. Postpaid.
Lber.

167. Eden Gem or Netted Roek Rocky Ford Cantaloupe This magnificent new Muskmelon is a selection of the old Rocky Ford, which it completely surpasses in lusciousness, yield. carrying, and good selling qualities. In shape it netted. Plits. 5c and 10c. Oz. 10c. 1/1 Lb. 20c. $1 / 2 \mathrm{Lb}$. 35c. Lb. 65.

334. Pollock Rocky Ford Cantaloupe. A rust-resisting melon, with netting over the blossom end: not a long melon but rather inclined to be short, with the finest shipping and eating qualities. The selections from time to time have reduced the size; now they crate nicely. Pkts. 5c and 10c. Oz. 10c. 1/4 Lb. 20c. 1/2 Lb. 35c. Lb. 65c.

337. Knight, or New Maryland Cantaloupe. A very popular melon with large growers and shippers; somewhat original stock, which is verr fine. Pkts. $5 \mathrm{c}$ and $10 \mathrm{c}$. $\mathrm{Oz} .10 \mathrm{c}$ original stock, which is vers fine. Pkts. 5c al

111. Norfolk Button. They are excellent little melons. Very early in maturing, thick, green flesh, uniform in size, and with an occasional button at the blossom end. Deliciolssly sweet. Pkts. 5c and 10c. Oz. 10c. 1/4 Lb. 20c. Lb. 65c.

165. Improved Jenny? Lind. The Jenny Lind is the known. It is very uniform in size, well netted and with thick meat. Smail
seed cavity. Pkts. 5c and 10c. Oz. 10c. 1/4 Lb. 20c. Lb. 65c.

\section{Baltimore Nutmeg Cantaloupe}

170. Is delicious in flavor, attractive in form and color, and unexcelled as a shipper. Our seed of Baltimore Nutinviorating climate This insures a parent stock of the finest flavor. WVe recommend this melon, and firml believe the cash balance of every trucker will be materially inthe cash balance of every trucker will be materially in-
creased if he grows our superior stock of Nutmeg Cantaloupe. Plats. 5c and 10c. Oz. 10c. $1 / 4$ Lb. $20 \mathrm{c} .1 / 2 \mathrm{Lb}$. $35 \mathrm{c}$. Lb. 65c. Postpaid.

517. New Ford Hook. This melon is a cross between the Emerald Gem and Improved Jenny Lind. It has very thick, deep, salmon-colored flesh, surpassingly sweet to the very rind. It is quite early, vigorous in growth, and extremely prolific. Price: Pkts. $5 \mathrm{c}$ and 10c. Oz. 10c. 1/4 Lb. 0c. $1 / 2$ Lb. $35 \mathrm{c}$. Lb. $60 \mathrm{c}$.

353. Extra Farly Osage Gem. Round, well netted, thick, Plits. $5 \mathrm{c}$ and 10c. Oz. 10c. $1 / 1$ Lb. 20c. Lb. 60c. 351 . Ferry's Defender. Medium size, flesh firm, fine grained, rich, deep rellow, highly flavored. A splendid shiprer. Pkts. $5 \mathrm{c}$ and 10c. Oz. $10 \mathrm{c}$. $1 / 4 \mathrm{Lb} .20 \mathrm{c}$. $\mathrm{Lb}$. $60 \mathrm{c}$. flavor. It looks and smells like a hanana. Not a mere curiosity, hut is in such favor as to command prices from $50 \mathrm{c}$ to $\$ 1.00$ for a single specimen. Pkts. 5c and $10 \mathrm{c} . \mathrm{Oz}$ 10c. $1 / 4$ Lb. $25 \mathrm{c} .1 / 2$ Lb. $40 \mathrm{c}$. Lb. $75 \mathrm{c}$. 
Better Than

"Tom Watson"

Ever Was

\section{as}

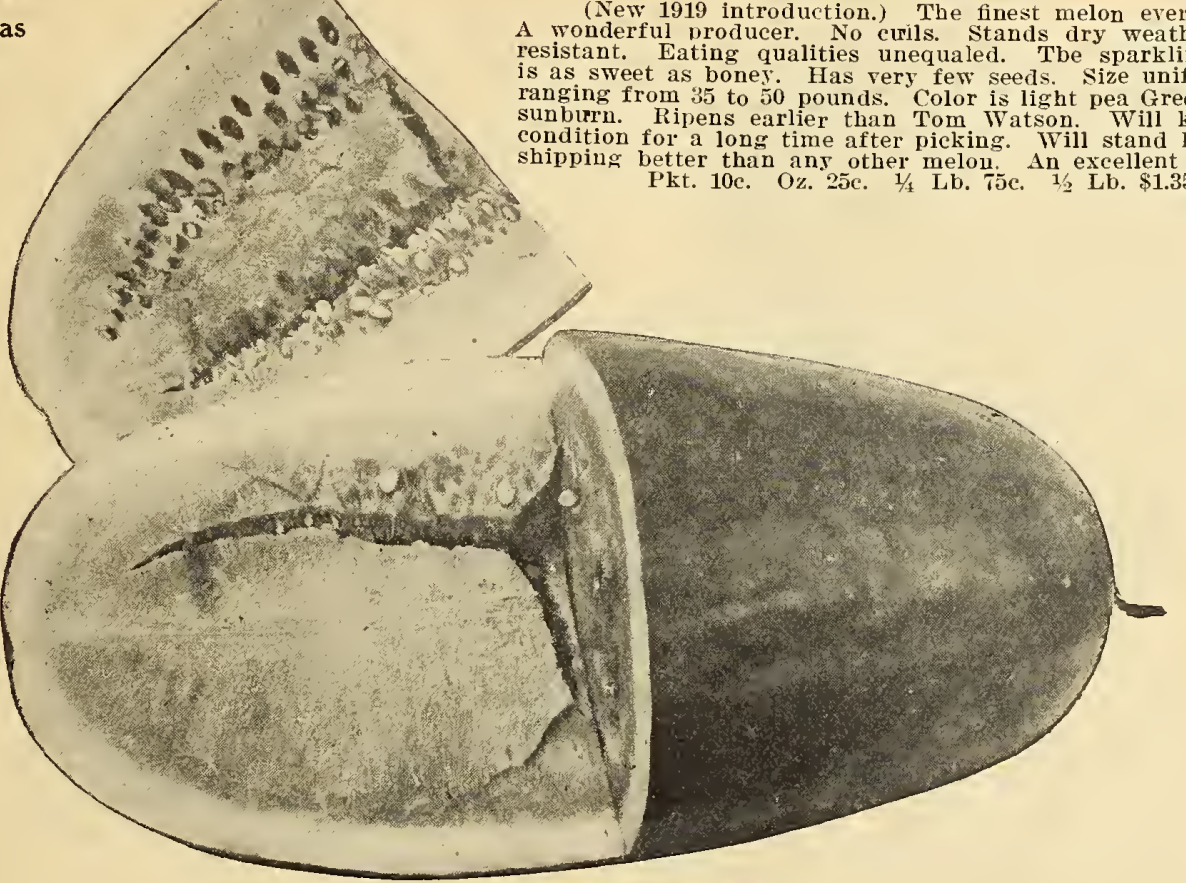

"General Pershing" Watermelon

WATERMELON

Culture. The soil for Watermelons must be light, rich and sandy, for if grown on a heavy soil the quality will be poor, and tbey will not be so early. When there is no more danger of frost drop 8 to 10 seeds in hills 8 to 10 feet apart eacb way, covering about $1 / 1 /$ inch deep. As soon as plants commence to run, tbin out to 3 best plants in a bill, and cultivate until tbe vines cover tbe whole ground. If slow to fruit, pineb off the ends of tbe growing shoots. Ash or air-slaked lime sifted on tbe young plants while dew is on is good to keep insects out. One ounce will plant about 30 bills, and it takes 3 to 4 pounds to an acre.

146. Goliath. The New Giant Watermelon; large, enormously productive; bas a rich, dark green skin; fine quality, remarkable sbipper. Pkts. 5c and 10c. Oz. 10c. 1/4 Lb. 20c. $1 / 2$ Lb. 35c. Lb. 60e. Postpaid.

172. Indian Chief, Bolgiano's Wonderful New Watermelon. Distinct from all other varieties. Has ereated a sensation. Pkts. 5c and 10c. 1/4 Lb. 20c. 1/2 Lb. 35c. Lb. 60c. Postpaid.

565. Mountain Sweet. An old favorite variety, but still the standard of excellence for quality; fruit long and the standard of excellence for quality; fruit long an 566. Duke Jones. One of the largest and most productire melons. Early, round and of fine appearance; of fine flaror and a good shipper. Pkt. 5e. Oz. 10c. 1/4 Lb. 15c. Lib. $45 \mathrm{c}$.

188. Sweet Heart. Globular in shape, skin very bright mottled green, flesb bright red, firm and heavy, but exceedingly sweet. Pkt. 5c. Oz. 10c. 1/4 Lb. 20c. Lb. 50c.

177. Lord 13altimore. Oblong, ligbt and dark green stripes. Pkt. 5c. 1/4 Lb. 15c. Lb. $45 \mathrm{c}$.

192. Kleckley's sweet. Oblong, dark green. Pkt. 5c. Oz. 10e. 1/4 Lb. 15e. $1 / 2$ Lb. $25 \mathrm{c}$. Lb. $45 \mathrm{c}$. 181. Alabama Sweet. Good size, very uniform, long, dark green skin, red flesh, aboslutely stringless and luseious in quality. Pkt. 5c. Oz. 10c. 1/4 Lb. 15c. Lb. $45 \mathrm{c}$.

182. Black Boulder. Uniformly oblong in shape, very dark green skin, red flesb. Pkt. 5c. Oz. 10e. 1/t/ Lb. 15c. $1 / 2$ Lb. 25c. Lb. $45 \mathrm{c}$.

406. Irish Gray Watermelon. The size is uniform and large. Color of rind yellowisb gray and almost as tough as that of the Citron. Ripens earlier than Tom Watson and will keep in good condition for a long time after picking. Very prolific and a good sbipper. A fine market sort. Pkts. 5e and 10e. Oz. 15c. 1/1 Lb. 40e. 1/2 Lo. ruc. Lb. $\$ 1.25$. Postpaid.

180. Kolb Gem. Of a delicious, sugary flavor; bright red Oz. 10c. It/t Lb. 20c. Lb. 50c.

171. Bolgiano's Cold Mountain Spring Watermelon. Tbe ideal melon for Southern shippers, prolific, uniformiy goou size, tough rind, flesh firm and delicious. Pkts. 5e and 10c. Oz. 10c. 1/4 Lb. $20 \mathrm{c}$. $1 / 2$ Lb. 35c. Lb. 60c. Postpaid.

174. Bolgiano's Black Striped Ko!b Gem Watermelon. (Called "Stripes,") A fine shipper. Melons uniformly large. 'Thick, oval form. Color is a rich, dark green, with fine stripes of ligbter shade. Plkt. 5c. Oz. 10c. 1/t Lb. 20c. $1 / 2$ Lb. 30c. Lb. 50c. Postpaid.
405 “General Pershing” Watermelon

The Leader of Them A.1.

New 1919 introduction.) The finest melon ever introduced. onderful producer. No cuils. Stands dry weather. Disease istant. Eating qualities unequaled. Tbe sparkling red flesh as sweet as boney. Has very few seeds. Size uniformly large, for 35 to 50 pounds. Color is light pea Green. Will not dition for a long time after picking. Will stand long-distance better than ans other melou. An excellent table melon.
Pkt. 10c. Oz. 25e. 1/4 Lb. T5e. 1/2 Lb. $\$ 1.35$. Lb. $\$ 2.50$.

In Lots of 5 Lbs.

381. "Excel"-The New Watermelon. A long, green melon witb visible stripes. Handsome in appearance and far surpasses tbe Tom Watson, both as a sbipper and for the table. Pkt. 10c. Oz. 10c. $1 / 4$ Lb. 20c. 1/2 Lb. 35c. Lb. 60e. Postpaid.

175. Luscious Favorite Watermelon. It is vigorous and productive, the outer color is very brigbt, being a beautiful mottled light green. The rind is tbin and tougb and stands sbipping perfectly ; it is an excellent keeper and improves its quality after ripening. It bas an attractive sbape, flesh is light, vivid red in color, and very solid, erisp, tender, melting and sweet. Tbe flavor is exquisite, possessing not only tbe ordinary sweetness, but a luscious flavor not to be found in otber sorts. Every grower wbo gives this melon a trial will be thorougbly convinced of its superior merits. Pkt. 5c. Oz. 10c. 1/4 Lb. 20c. Lb. 50c.

178. Georgia Rattlesnake or Striped Gypsy. Has gained great popularity for its large size and great shipping qualities; shape oblong, of light green color and beautifully mottled and striped with a ligbt shade; flesb scarlet, rind thin, very solid, and both sweet and delicious. Pkt. 5c. Oz. 10c. 1/4 Lb. 15e. 1/2 Lb. 25e. Lb. $45 \mathrm{c}$.

176. Forida Favorite Watermelon. The flesh is a beautiful, clear crimson, extending to the rind. Tbe rind is tough, making it an excellent shipper. It is beautifully striped ligbt and dark green, and a very large yielder. The shape is oblong, the flavor is sweet and melting, making it one of the best in cultivation, both for the bome garden and large growers. Pkt. 5c. Oz. 10c. 1/4 Lb. 15c. Lb. $45 \mathrm{c}$.

245. Tom Watson Watermelon. A large, oblong melon, dark green skin, with thick netting. Rind is thin but tough. The flesh is bright, attractive red color, of a delicious, most satisfying flavor. Pkt. 5c. Oz. 10c. 1/4 Lb. 15c. $1 / 2$ Lb. 25 c. Lb. $45 \mathrm{c}$. Postpaid.

31. Halbert Honey. Average 18 to 20 incbes long, blumtl ${ }_{Y}$ rounded at both ends. Skin dark, glossy green. Flesb a beautiful, rich crimson, sweet and luscious, ripens to the rind. Pkt. 5c. Oz. 10e. 1/4 Lb. 20e. Lb. 50c.

183. Black Diamond. Large, round, dark green skin. Pkt. 5c. Oz. 10c. 1// Lb. 15e. 1/2 Lb. 25c. Lb. $45 \mathrm{c}$.

267. Success Waterme!on. A fine, large, round dark green melon, originated in Maryland, of excellent shipping and eating qualities $\mathrm{pkt}$.

173. Cole's Early Watermelon. Sureeeding in many States wbere melons were never matured before. Tbe flesb is a beautiful. bright red color, erisp and extremely delicate in texture; flaror is luscious, sweet and refreshing; no pethiness or stringiness. Pkt. 5c. Oz. 10c. 1/4 Lb. 15c. Lb. 45 .

\section{CITRON}

552. Colorado Preserving. A large, fruiting Citron for preserving. Pkt. 5e. Oz. $10 \mathrm{c}$. 1//1 Lb. $20 \mathrm{c} .1 / 2$ Lb. 30c. Lb. $50 \mathrm{c}$.

516. Red Seeded Citron. Fruit round and handsome. Pkts. 5.c and 10c. Oz. 10c. 1/4 Lb. 15c. 1/2 Lb. 25c. Lb. $45 \mathrm{c}$. 
1818-J. Bolgiano \& Son, Seedsmen, Baltimore, Md.-Fall, 1919.

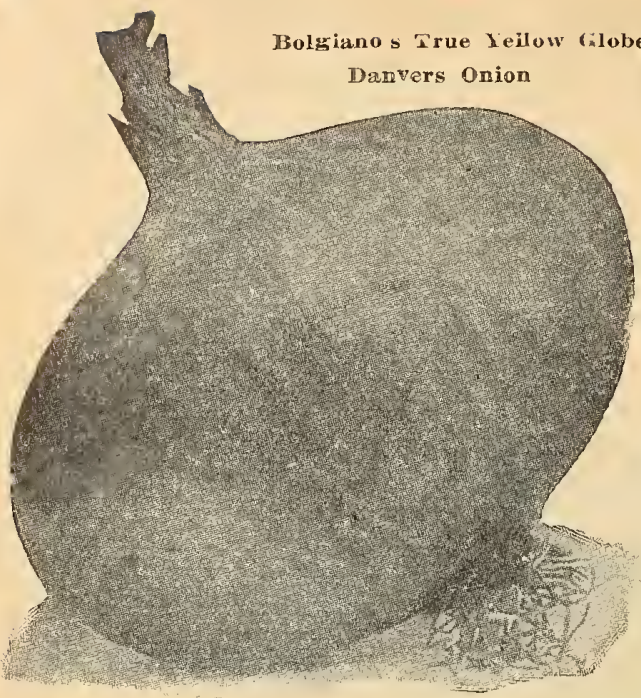

Pkts., Ozs. and $1 / 4$ OniOn one O\%. to $100 \mathrm{Ft}$. of Drill. 4 to $5 \mathrm{Lbs}$. to the Acre. In Lots of 5 Lbs. or Mrore Deduct 5e Per Lb. In Lots of $10 \mathrm{Lbs}$. or More Deduct 10c Per Lb.

214. White Silver Skin Onion. This superior stock is almost exclusively used for growing sets, which is the strongest proof that it is the best from which to grow the large white onions. Its delicate, mild flavor, stately form. Pkts. 5c and 10c. $1 / 2 \mathrm{Oz}$. 15c. 2 Ozs. 35c. $1 / 1$ Lb. 60c. $1 / 2$ Lb. $\$ 1.10$. Lb. $\$ 2.00$. Postpaid.

205. Mammoth Prizetaker Onion. True American Seed. Immense size, 12 to 18 inches in circumference, bright straw color, flesh white. Pkts. $5 \mathrm{c}$ and 10c. $1 / 2 \mathrm{Oz}$. 15c. Oz. 20c. $1 / 4 \mathrm{Lb}, 60 \mathrm{c}$. $1 / 2 \mathrm{Lb}, \$ 1.10$. Lb. $\$ 2.00$. Postpaid.

$341 \frac{1}{2}$. Southport White Globe. A large, globe-shaped Onion ; firm, fine grained, of mild flavor; keeps well. Pkts. 5c and 10c. 1/2 Oz. 15c. Oz. 2uc. 2 Ozs. 30c. 1/4 Lb. 50c. 1/2 Lb. 95̄c. Lb. $\$ 1.75$.

575. Southport Large Yellow Giobe. Produces bulbs more perfectly globe-shaped and larger than Globe Danvers, but later in lipening; excellent keeper. Pkts. 5c and 10c. 1/2 Oz. 15c. Oz. 20c. 2 Ozs. 30c. 1/4 Lb. 50c. 1/2 Lb. 90c. Lb. \$1.65. Postpaid.

576. Southport Large Red Globe Onion. Produces large, handsome, globe-shaped bulbs from the seed the first season; are excellent keepers. Pkts. 5c and 10c. $1 / 2$ Oz. 15c. Oz. 20c. 1/4 Lb. 50c. 1/a Lb. $90 \mathrm{c}$ Lb. $\$ 1.65$.

216. Round Yellow Danvers. Is the same shape as the White Silver. Brownish-yellow color; bulbs quite flat and of good size. They are hardier than the white and keep better through the Winter. Pkts. 5c and 10c. Oz. 15c. 1/4 Lb. 45c. Lb. \$1.50. Postpaid.

13. Mammoth Silver King. Bulbs of attractive form, flattened, but thick through; average diameter 5 to 7 inches. Pkts. $5 \mathrm{c}$ and $10 \mathrm{c}$ Oz. 20c. $1 / 4$ Lb. 60c. $1 / 2$ Lb. $\$ 1.10$. Lb. $\$ 2.00$.

213. Wammoth Sivver King. Bulbs of attractive form, Hattened, but thick through; average diameter 5 to 7 inches; single bulbs often weigh 2 to 3 pounds; skin is a clear, silvery white; flesh snow white, sweet and tender. Pkts. cc and 10c. Oz. 20c. $1 / 4$ Lb. 60c. $1 / 2$ Lb. $\$ 1.10$. Lb. $\$ 2.00$.

210. Extra Early Pearl, White Queen, or Barletta onion. Enormous size; grows full-sized roots from seeds the first season; skin pure white, waxy color, flesh snowy white, delicate and tender. Pkts. $5 \mathrm{c}$ and $10 \mathrm{c} .1 / 20 \mathrm{z} .15 \mathrm{c}$. Oz. 30c. $1 / 4 \mathrm{Lb}$. 90c. $1 / 2 \mathrm{Lb}$. $\$ 1.75$. Lb. $\$ 3.25$. Postpaid.

536. Bolgiano's Yellow Dutch or Strasburg. Grows round, plump sets. Skin a bright attractive straw color. Full-sized Onions are flattened. Pkts. 5c and 10c. Oz. 15c. 2 Oz. 25 c. $1 / 4$ Lb. 45 c. $1 / 2$ L b. 80 c. L b. $\$ 1.50$. Postpaid.

206. Yellow Globe Danvers Onion. Bolgiano's True Stock. Handsome form, very thick bulb, small neck; very early. Pkts. 5c and 10c. 1/2 Oz. 10c. Oz. 15c. 1/4. Lb. 45c. early. Pk. 80c. Lb. $\$ 1.50$.

212. Red Wethersfield Onion. The most beautiful, large, handsome, globe-shaped red Onion. Perfect form, pro-
fuces enormous Onions. Pkts. 5e and 10c. 1/2 Oz. 15c. Oz. 20c. 2 Ozs. 30c. $1 / 4$ Lb. 50c. $1 / 2$ Lb. 90c. Lb. $\$ 1.65$. Postpaid.

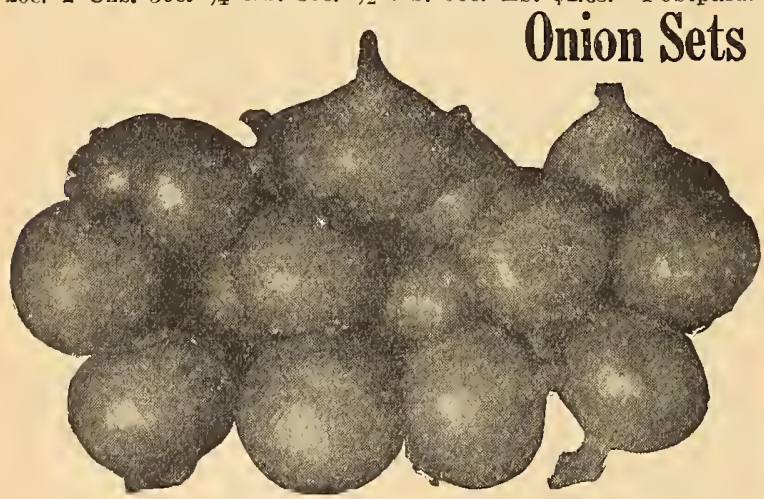

511. Large White Portugal. The standard, large, flat variety. Pkts. 5c and 10c. $1 / 2$ Oz. 15c. Oz. 20c. 1/4 Lb. $60 \mathrm{c}$ $1 / 2$ Lb. $\$ 1.10$. Lb. $\$ 2.00$. Postpaid.

Extra Early Barletta...........5 and $10 \mathrm{c}$ 30c 90e $\$ 3.25$

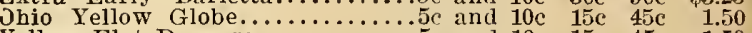
Yellow Flat Danvers.............5 and $10 \mathrm{c}$ a $15 \mathrm{c}$ and $45 \mathrm{c}$

BermudaOnions, Genuine Teneriffe Grown

577. White Bermuda Onion, Teneriffe. It is oval in shape, of a white color: ; quite early, very solid, does not skin in transportation and keeps better than any other foreign variety. It is of a mild and delicate flavor. Pkts. $5 \mathrm{c}$ and 10c. Oz. 20c. 2 Ozs. 30c. 1/4 Lh. 50c. 1/2 Lb. 90c: Lb. \$1.65. Postpaid.

578. Crystal Wax-onion, Teneriffe. The newest and best, pure crystal white wax Bermuda Onion that has ever been developed. Pkts. 5c and 10c. Oz. 30c. 2 Ozs. 5jc. 1/4 Lb. 90 c. $1 / 2$ Lb. $\$ 1.75$. Lb. $\$ 3.25$. 579 . Red Bermuda Onion, Teneriffe. Shape and size similar to white, differing only in color; a most desirablesort. I'kts. $5 \mathrm{c}$ and 10c. Oz. 20c. 2 Ozs. 30c. $1 / 4$ L b. $50 \mathrm{c}$

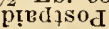

BERMIUDA ONION SETS

For Shipmen' Righ After Harvest White Pearl Sets. 15c. Qt. 25c. 4 Qts. $65 \mathrm{c}$ Pk. \$1. 32-lb. bu. $\$ 3.25$. Pt. 15c. Qt. 25e. + Qts. 65̃. Pk. \$1.00. 32-1b. bu. $\$ 3.25$.

White Queen Sets. Pt. 15c. Qt. $25 \mathrm{c} 4$ Qts 65c. Pk. \$1.00. 32-1b. bu.

White Barletta Sets. Pt. 15c. Qt. $25 \mathrm{c} .4$ Qts 65c. Pk. $\$ 1.00 .32-1 \mathrm{~h}$. bu. $\$ 3.25$.

Prices given below are those ruling when this catalog goes to press and subject to market changes. Write for special Prices when ready to buy. We give a weight bushel of 32 pounds.

By mail, add $10 \mathrm{c}$ per $\alpha t$. Plant in drills 12 inches apart, and 4 inches in the rows. Must have high culture.

White Silver Skin onion sets. Grown from o $\mathrm{nr}$ choice strain of White Silver Skin or Portugal Onion Seed. Pt. 15c. Qt. 20c. $1 / 2$ Pk. 50c. Pk. 85c. Bu. \$2.75.

Large Red Wethersfleld. Choicest recleaned. Grown from seed of our celebrated strain of Rerl Wethersfield Onion. Pt. 10c. Qt. 15c. 1/2 Pk. 45c. Pk. 75c. Bu. \$2.25.

Yeliow Danver Onion Sets. Choice recleaned. Grown from our choice strain of Yellow Strasburg or Dutch Onion Seed. They will produce handsome, well ripened bulbs of large size quite early in the Summer. Pt. 10c. Qt. 15c. 1/2 Pk. 45c. Pk. 75c, Bu, $\$ 2.25$.

\section{One Ounce to 100 feet of Drit, Parsnip Parcel Post Rates, see Page 2.
5 to 6 pounds for an Acre.}

19. Bolgiano's Hollow Hub Parsnip. The very best of all Parsnips; it is unequaled. Pkts. 5c and 10c. Oz. 10c. 1/4 Lb. 30c. 1/2 Lb. 50c. Lb. 90e. 5 Lbs. at 85e lb. Postpaid.

220. Hollow Crown Sugar Parsnip. Is fine grained, true hollow crown; has thick shoulders tapers symmetrically to a single tap root. Are easily gathered; heavy croppers; roots run uniformly smooth, with fine grained flesh, and good quality. Pkí. 5c. Oz. 10c. 1/4 Jb. 30c. 1/2 Lb. 50e. Lb. 90e. 5 Lhs. at $85 \mathrm{c}$ lh.

569. Guernsev. (Improved Haif Long.) A greatly improved strain. The roots do not grom is long as the Hollow Crown, but are of greater diameter and inore easily gathered. A heary cropper. The roots are very smooth: the flesh is fine rrained and of most :cellent quality.

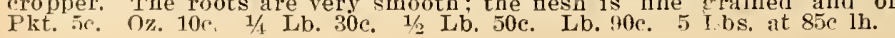

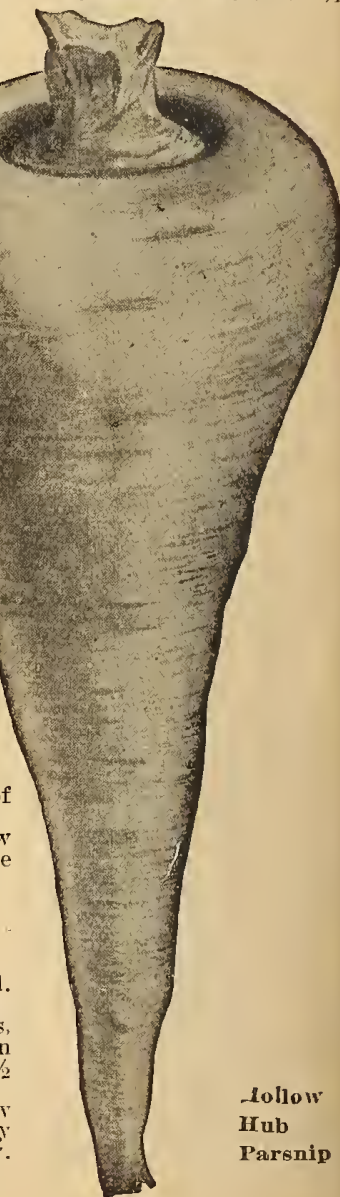


Parcel Past Rates, see Page 2
Finst-Class Selected Stocks
Finest Hand Picked Samples

Extra Early Smooth Seed Peas, weight by Parcel Post: Pt. 2 lbs. Qt. 3 lbs. 4 Qts. 9 lbs. Pk. 17 lbs.

All Wrinkled Seed Peas, weight by Parael Post: Pt. 1 lb. Qt. 2 lbs. 1 Qts. S lbs. Pk. 15 lbs.

One quart will plant about 100 feet of drili. One and one-half to two bushels for an acre.

Those Marked With a Star (*) are wrinkled marrows, and unless otherwise stated should be sown thicker than the round Peas, and not until the ground has become warm, as they are more liable to rot. They are the finest flavored of all Peas.

\section{Extra Early Dwarf Varieties}

\section{"EARLY BIRD" PEAS}

1048. Bolgiano's New Early Large Pod Pean A very early, hardy, large podded 2 to $21 / 2$-foot Pea. very early, hardy, large podot with pods double the Can be pulco as earler, heary cropper, 9 to 10 Peas size. A robust grow sown with safety as soon as the in a pod. Can be sown with safety as soon as the ivrite for lowest prices spring Delivery.

1218. *'100 Per Cent Profit" "Peas. Earlier, dwarfer, more prolific, more delicious than either the Gradus or the Thomas Laxton Pea. It is a wonder. Try it. 1/2 Pt. 20c. Pt. 35̃c. Qt. 65̃e. 4 Qts. \$2.25. Pk. $\$ 4.00 .2$ Bu. $\$ 15.00$

1261. Little Marvel Peas. Vines of d warf, evell growth, averaging 15 inches in height. Heavily set with fine pods and frequently borne in pairs. Ready for table fully as early as American Wonder; rines are larger and prodwce a much heavier crop. Sold out immediate

1081. *American Wonder. It is of dwarf and robust habit. 10 to 15 inches high, and produces a profusion of good-sized and well-filled pods of fin ast flaror. Height 1 foot. Pkt. 10c. Pt. 25c. Qt. 45c. est flavor. Height 1 foot. Pkt. 10c.

1084. *Extra Eariy Premium Gem. Early, large, wellfilled, straight pods. Height 1 foot. Pkt. 10c. Pt. 25c. Qt. 45e. "4 Qts. $\$ 1.50$. Pts. $\$ 2.75$. Bu. $\$ 10.00$.

1196. *McLeon's Little Gem. Very early; prolitic; delicious flavor. Height 11/4 feet. Ptt. 10c. Pt. 25c. Qt, 45c. 1 Qts. $\$ 1.50$. Pk. $\$ 2.75$. Bu. $\$ 10.00$.

1080. *Nott's Excelsior Pea. The very best, short vine, wrinkled, extra early Pea. Vines are more vigorous and taller than the American Wonder, and the pods are one-third larger, than the American to 8 large Peas, very close together, and for sweetness and quality has no equal. Height 1 foot. Pkt. 10e. Qt. 45c. 4 Qts. \$1.50. Pk. \$2.75. Bu. \$10.00.

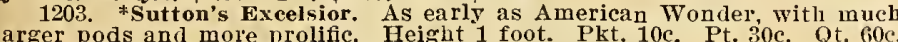
4 Qts. $\$ 2.00$. Pk. $\$ 3.60$. Bu. $\$ 14.00$.

1230. *Tom Thumb or Blue Peter Peas, Popular, very dwarf, prolific Pea. Height 1 foot. Pkt. 10c. Pt. 25c. Qt. 45e. 4 Qts. $\$ 1.50$. Pk. $\$ 2.75$. Bu. $\$ 10.00$.

Laxtonian Peas. Pkt. 10c. 1/2 Pt. 25c. Pt. 40c. Qt. 70c. 4 Qts. \$2.25. Pk. \$4.00. Bu. $\$ 15.00$.

\section{Extra Early Varieties}

1087. New Long Podded Alaska Pea. We recommend this new Pea as the great t noney making Pea that has heen introduced since we first put out the wondel Worker Pea. Be sure to give it a trial. Height 21/2 feet. Pkt. 10c. Pt. 25c. Qt. 40c. 4 Qts. \$1.35. Pk. \$2.50. Bur. $\$ 9.00$.

1029. The Hustlers. Bolgiano's New, extremely early, green seeded and handsome green podded big vielding Peas, Height $21 \%$ feet. Pkt. $10 \mathrm{e}$ Pt 250 , 45e. 4 Qts. \$1.50. Pk. \$2.75. Bu. \$10.00 1088. New Extremely Early Prolific Bolgiano's "Good LUCK" Peas. Crop very short this year. Height $21 / 2$ feet. Pkt. 10c. Pt. 30c. Qt. 50c. 4 Qts. $\$ 1.65$. Pk. \$3.00. Bu. $\$ 11.00$

1071. Bolgiano's Extra Early, Alaska Peas. By carefll selection and thoroughly rogueing, we have developed a stock of this smooth, blue Pea, which in evenness of growth of vine and early maturity of pods is mequaled. The vines are about $2 \frac{1}{2}$ feet high, not branching, but bear 4 to 7 long pods filled with medium-sized, beautiful, kright green, smooth Peas of excellent flaror. Height $21 \frac{1}{2}$ feet. Pkt. 10c. Pt. 20c. Qt. 35e. 4 Qts. \$1.25. Pk. \$2.25. Bu. $\$ 8.50$.

1070. Bolgiano's Extra Early Triumph Peas. Our standard market garden extra early Pea; productive and profitable to grow. Height 21 feet. Pkt. 10c. Pt. 30c.

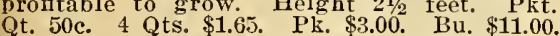

1201. Pedigxee Extra Early. Also known as "The New Early Pea." Extremely early, wonderfully productive and exceptionally uniform stock. Height $2 \frac{1}{2}$ feet. Pkt. 10c. Pt. 30c. Qt. 50c, 4 Qts. $\$ 1.65$ Pl. $\$ 3.00$, Bu. $\$ 11.00$

1202. Prolific Early Marlet. Not quite so early as the Pedigree, but the most productive of all the Extra Early Peas. Beautiful large pods, fine quality, one of the best Peas ever introduced. Height $21 \%$ feet. Pkt. 10c. Pt. 30c. Qt. 50c. 4 Qts. $\$ 1.65$. Pk. $\$ 3.00$. Bu. $\$ 11.00$.

1016. Ameer Peas. An exceptionally profitable Early Pea. Green seed. Height $21 \frac{1}{2}$ feet. Plit. 10c. Pt. 25e. Qt. 40c. 4 Qts. $\$ 1.35$. Pk. $\$ 2.50$. Bu. $\$ 9.00$

1260. Bountiful Peas. Bears an abundance of beautiful, green pods, crowded with delicious Peas. Extremely early. Height $21 \%$ feet Plt. 10c Pt. 30c. Ot. 50c. 1 Qts. $\$ 1.65$. Pk. $\$ 3.00$. Bu. $\$ 11.00$.

1082 Bolgiano's Extra Early Nonpareil Peas. It is used by many of our Southern customers. The entire crop can be had in a single picking, and its beautiful green pod retains its color and freshness longer than any other sorts. It is an abundant cropper and the pods good sized. It suits long-distance shipping. Height $21 / 2$ feet. Pkt. $10 \mathrm{c}$. Pt. 20c. Qt. 35c. 4 Qts. $\$ 1.25$. Pk. $\$ 2.25$. Bu. $\$$ s.50.

1073. Extra Early Morning Star Peas. Many of our largest customers use this Pea, and it gives satisfaction. Height $21 / 2$ feet. Pkt. 10c. Pt. 30c. Qt. 50c. 4 Qts. $\$ 1.65$. Pk. $\$ 3.00$. Bu. $\$ 11.00$.
1074. First and Best. First-class selected strain of extra early earlies. Height $2 \frac{1}{2}$ feet. Pkt. 10c. Pt. 30c. Qt. 50c. 4 Qts. $\$ 1.65$. Pk. $\$ 3.00$. Bu. $\$ 11.00$

1181. "Large White Marrowfat Peas. Jleight 5 feet 10c. Pt. 20c. Qt. 30c. 4 Qts. \$1.10. Pz. \$2.00. Bu. $\$ 7.00$ Best Heirht 21/ feet Pkt 10c Pt. 30c. Qt. 50c 4 ots $\$ 1.65$. Pk. $\$ 3.00$. Bu. $\$ 11.00$.

1072. *Gradus, or Prosperity Peas. Gradus is in condition to pick about 4 days after our Early Triumph. The pods are very large and well filled with large, wrinkled, deel green Peas of the finest quality. Hejght 3 feet. Pht. 0c. Pt. 30c. Qt. 50c. 4 Qts. \$1.75. Pl. \$3.25, Bu. $\$ 12.00$. growth and abundant, large and handsome pods reward cultiration. It is aronn extensively hy the largest truckers. Height 3 feet. Pkt. $10 \%$. $\Gamma^{*} .25 \%$ Qt. $40 \%$ \& 4 ts. $\$ 1.35$. Pl. \$2.50. Bu. $\$ 9.00$.

1075. Rural New Yorker. Porls of fine shape: contains from 6 to 9 Peas of fiue quality, prolific, extra early. uniform in growth and ripening. Height $21 / 2$ feet. Pkt. 10c. Pt. 30e. Qt. 50c. 4 Qts. $\$ 1.65$. Pk. $\$ 3.00$. Bu. $\$ 11.00$.

1078. Thomas Laxton. A cross between Gradus and one of the extra early sorts. It ripens within a day or two of the carliest round varieties. Height 1 foot. Pkt. 10 1076. Frenci Canners Peas. A little later than the Alaska or Fxtra Carly Peas. Verv prolific. Height $31 \%$ feet. Pkt. 10c. Pt. 20c. Qt. 35c. 4 Qts. \$1.25. Pk. \$2.25. u. $\$ 8.50$.

1083. Bolgiano's Wonder Worker Pea. Earliest Extra Early Wrinkled Pea. Most profitable for growers and stip50c. 4 Qts. \$1.75. Pk. \$3.25. Bu. \$12.00. 


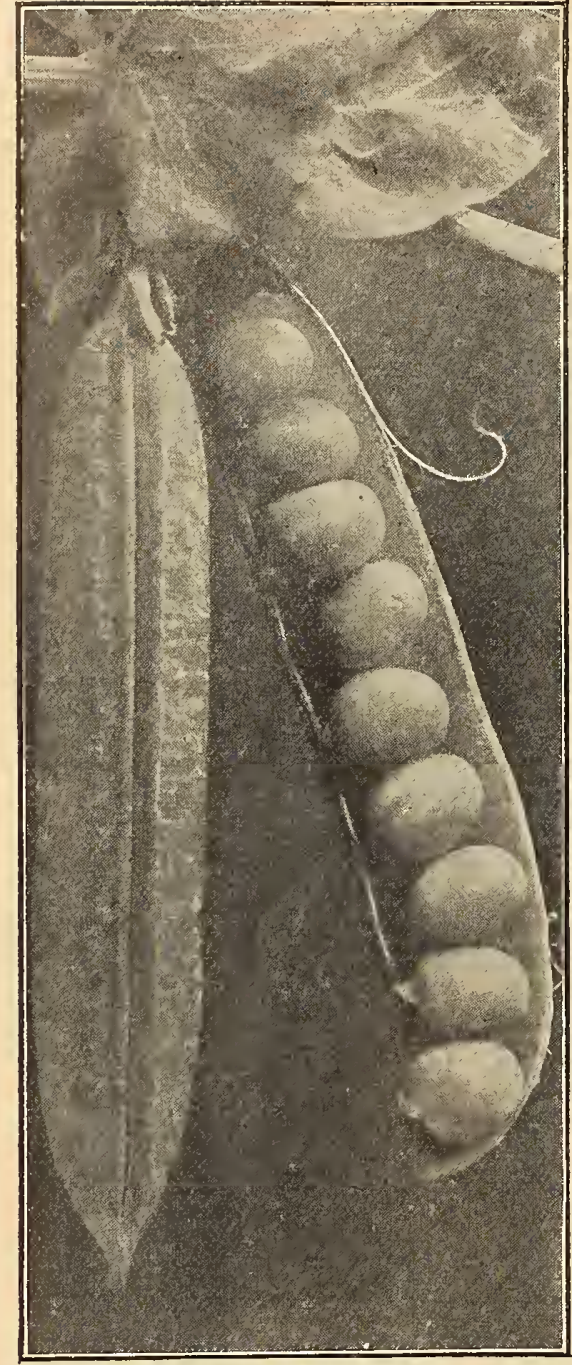

"Cracker Jack" Peas
Peas continued

\section{Second Early and General Crop Varieties}

\section{"Cracker Jack" \\ Bolgiano's Second Early Wrinkled Pea}

"CRACKER JACK" continues to bear an abundance of most delicious Peas, when all other varieties are dried up from the hot sun of the early Summer.

10S9. Bolgiano's Cracker Jack Pea. 1. A tronderful yielder. 2. Vines 2 feet 2 inches high. 3. Growth hardy, robust and vigorous. 4. Extremely large pods, have a handsome, dark-green color and a re borne even more abundantly than on the Dwarf Prolific Green Marrow Peas. 5 . Ready for market just the Wonder Worker Peas are ofer 6. If planted a little late will stand the warm weather excellently. 7. It's the Pea market gardeners have been looking for, and it's a cracker Jack." Pkt. 10c. Pt. 25c. Qt. 45c. 4 Qts. $\$ 1.50$. Pk. $\$ 2.75$. Bu. $\$ 10.00$.

1231. *Horsferd's Market Gardeners' Pea. One of the largest rielding second early Peas in cultivation, a single plant bearing 150 pods. only 2 feet high, requiring no stakes. A fine market-garden Pea and equally good for home use. The pods are borne in pairs and are easily and quickly picked. Pkt. 10c. Pt. 25c. Qt. 40c. 4 Qts. $\$ 1.35$. Pk. \$2.50. Bu. $\$ 9.00$.

1090. *Dwarf Giant Podded Prolific Green Marrow Pea. Bears enormous. handsome pods 7 to 8 inches in length, filled with large deep green Peas: requires no support. Height 2 feet. Pkt. 10c. Pt. 20c. Qt. 35c. 4 Qts. $\$ 1.25$. Pk. $\$ 2.25$. Bu. $\$ 8.00$

1092. "Shropshire Hero. Very productive; fine flavor; long, handsome pods. Height 21/2 feet. Pkt. 10c. Pt. 25c. Qt. 40c. 4 Qts. $\$ 1.35$. Pk. $\$ 2.50$. Bu. $\$ 9.00$.

1093. "Champion of England. A well-known, standard variety; sow thickly. Height 5 feet. Pkt. 10c. Pt. 30c.. Qt. 50c. 4 Qts. \$1.65. Pk. $\$ 3.00$. Bu. $\$ 11.00$

12181/2. Alierman. (Admiral Dewey.) Extra 1rge, dark green pods. on order of Duke of Albany. Very fine. Height 4 feet. Pkt. 10c. Pt. 30c. Qt. 50c. 4 Qts, $\$ 1.85$. Pk. $\$ 3.35$. Bu. $\$ 12.50$.

1085. *Telephone Improved. Robust habit. A single vine produces 18 to 30 umusually long well-filled pods of larger size, containing 10 to 12 Peas, often forming a double row, of fine flavor. Height 5 feet. Pkt. 10c. Pt. 30c. Qt. 50c. 4 Qts. $\$ 1.85$. Pk. $\$ 3.35$. Bu. $\$ 12.50$.

1102. *Everbearing. A long time in bearing, Peas large, pods iong, 11/2 feet high. Pkt. 10c. Pt. 25c. Qt. 40c. 4 Qts. \$1.35. Pk. \$2.50. Bu. $\$ 9.00$.

1086. *Daisjz or Dwarf Telephone. Plants stout, self-supporting, heavy cropper. Height $11 / 2$ feet. Sold out immediately delivered. Write for lowest prices Spring Delicerv.

1094. *Dwarf Champion. A dTarf-growing Champion of England. In warm soils and location will give better results than the Height 2 feet. Pkt. 10c. Pt. 20c. Qt. 35c. 4 Qts. \$1.25. Pk. \$2.25. Bu. \$8.00. 1097. *Heroine. 21/2 feet high. Large pods, containing 8 to 9 large Peas of fine flavor. Pkt. 10c. Pt. 25c. Qt. 40c. 4 Q is. $\$ 1.35$. Bur. $\$ 9.00$

1098. *Juno. .2 feet high. Targe pods filled with large dark-green Peas of delicious flavor Pkt. 10c. Pt. 20c. Qt. 35c. 4 Qts. $\$ 1.25$. Pk. $\$ 2.25$. Bu. $\$ 8.00$.

1099. *Abundance. 3 feet high. Numerous, well-filled pods. Pkt. 10c. Pt. 25c. Qt. 40c. 4 Qts. $\$ 1.35$. Pk. $\$ 2.50$. Bu. $\$ 9.00$.

1110. *Improved Strategem Peas. Ver large, of finest quality. Height 11/2 feet. Price Pkts. 5c and 10c. Pt.
2 Qts. $\$ 1.30$. Pk. $\$ 2.40$. Bu. $\$ 9.00$. Qt. 40c. 2 Qts, 7sc. 4 Qts. $\$ 1.30$. PK, $\$ 2.40$. Bu. $\$ 9.00$. prolific. Pkt. 10c. Pt. 30c. Qt. 50c. 4 Qts. $\$ 1.85$. Pk. \$3.35, prolific. $\$ 12.50$

1199. *Edible Podded or Sugar Peas. Melting Sugar. Grow's to the heicht of 5 feet: bears a profusion of large, Grows to the height of broad pods, which are so brittle that they snap without
any string. Pkt. 10c. Pt. 30c. Qt. 50c. 4 Qts. $\$ 1.65$. any string. Pkt. 10

1091. * American Champion Peas. One of the largest Peas, productive, flavor and quality approaches that of the Well-known Champion of England. Pods full, contain 9 to 12 Peas. Height $51 / 4$ feet. Sow thinly. Pkt. 5e and 10c. Pt. 30c. Qt. 50c. 2 Qts, 95c. 4 Qts. \$1.85. PK. $\$ 3.35$. Bu. $\$ 12.50$

\section{0z. will sow 200 feet ParSleV $6 \mathrm{Lbs}$. to the Acre.}

221. Bolgiano's New Green Mountain Triple Parsley. Pkts. 5c and 10c. Oz. 15c. 2 Ozs. 25c. 1/1/ Lb. 40c. 1/2 Lb. 70c. Lb. \$1.25. Postpaid. 222. Market Gardeners' Best Triple Curled Parsley. Vely handsome plants are of a robust and free growth and it is improved by severe cutting; leares large, beautifully curled: rers dark green, stands the heat, drought and cold. Pkts, ac and 10c. Oz. 15c. 1/4 Lb. 30c. 1/2 Lb. 55c. Lb. \$1.00. 5 Lbs, at $90 \mathrm{e}$ Ib. Postpairt.

223. Extra Darl Champion uoss Curled Parsley. The large, moss, curled leaves are of rich

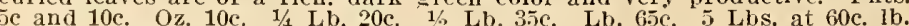

541. Fine Double Curled Parsiley. Ples. 5e and 10c. Oz. 10c. 1/4 Lb. 20c. $1 / 2$ Lb. $35 \mathrm{c}$. Lb. 65c. 5 Lbs. at $60 \mathrm{c}$. $1 \mathrm{~b}$.

540. Extra Curyed Dwarf or Emerald. Pkt. 5c. Oz. 10c. 1/4 Lb. 20 c. $1 / 2$ Lb. 35c. Lb. 65e. 5 Lbs. at 60c. Ib.

224. Plain or Single Parsley. Pkts. 5c and 10c. Oz. 10c. 1/4 Lb. 5.c. $1 / 2$ Lb. 45c. Lb. 80c. 5 Lbs. at 75c $1 b$.

Iramburg Rooted. Pkts, $5 \mathrm{c}$ and 10c. Oz. 10c. 1/4 Lb. 25c. 1/e Lb. $40 \mathrm{c}$ Lb. $75 \mathrm{c} .5 \mathrm{Lbs}$ at $65 \mathrm{c} 1 \mathrm{~b}$.

\section{CANADA FIELD PEAS}

165. Here is a crop that is not only profitable, but ill return to the land the much-needed nitrogen. Peas There is alwass a reads market for can be profitably ground and fed to the stock. The st doubled. Prices: Pkt. Jc and 10c. Pt. 15c. Qt. ts. 70c. Pk. \$1.25. Bu. \$4.50. 
Pkts., Ozs, and 1/4 Lbs. Pepper Parcel Post Rates,
Delivered Free.

Culture. Sow in hotbeds in March. and whell the soil has become warm set in rows 2 feet apart and 18 inches in the row; hoe frequentiy; the plants may also be forwarded in small pots.

163. Scarlet Mammoth, Boigiano's New Early Pepper. Mureh earlier and more prolific than the Chinese Giant. Pkts. $5 \mathrm{c}$ and 10c.

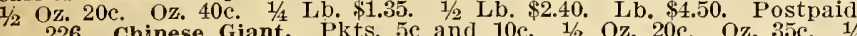

\$1. 15. Lb. \$2.15. Lb. \$4.00. Postpaid.

Lb. 396 world Beater. Pkts. $5 \mathrm{c}$ and $10 \mathrm{c}$. $1 / 2 \mathrm{Oz} .20 \mathrm{c} .0 z .35 \mathrm{c} .2 \mathrm{Ozs}$ (1/ Lb. $\$ 1.15$. $1 / 2$ Lb. $\$ 2.15$. Lb $\$ 4.00$

233. New Neopolitan, Pkts, 5c and 10c. 1/2 Oz. 20c. Oz. 30c. 3 zS. 55c. 1/4 Lb. $\$ 1.00$. 1/2 Lb. $\$ 1.90$. Lb. $\$ 3.50$.

nized Mammoth fuby King Peppers. Extra Selected Stock. RecPkts 5c and of the best Red Peppers for market or family use. Lb. \$4.00. Postpaid.

228. Bell or Hot Bull Nose, Large, hot, red, pickling. Pkts. 5c and 10c. Oz. 30c. 1/4 Lb. $\$ 1.00$. Lb. $\$ 3.50$. Postpaid.

562. Sweet Bull Nose. Pkts. 5e and 10c. Oz. 35c. 1/1/4 Lb. \$1.15. Lb. $\$ 4.00$.

229. Sweet Mountain. Flesh very thick and mild. Plkts. 5e and 10c. Oz. 35e. 1/4 Lb. $\$ 1.15$. Lb. $\$ 4.00$. Postpaid.

560. True Rexl Chili. Not as long or thick as Cheyenne. Pkts. 5e and $10 \mathrm{c}$. Oz, 30c. 1/4 Lb. $\$ 1.00$. Lb. $\$ 3.50$.

561. Long Red Cheyenne. For pickling. Pkts. 5c and 10c. Oz. 30c. $1 / 4$ Lb. $\$ 1.00$. Lb. $\$ 3.50$.

563. Red Cherry. Pkts. 5c and 10c. Oz. 30c. 1/4 Lb. $\$ 1.00$. Lb. $\$ 3.50$

427. Ruby Giant. Pkts. 5e and 10e. $1 / 4$ Oz. 20c. Oz, 35e. 2 Ozs. 65c. $1 / 4$ Lb. $\$ 1.15$. 1/2 Lb. $\$ 2.15$. Lb. $\$ 4.00$.

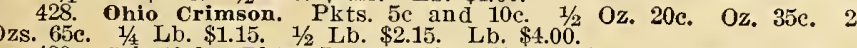

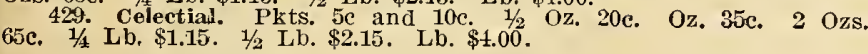

\section{Plts., Ozs. and 1/4 Lbs. Delivered Free.} Parcel Post Rates, see Page 2.

\section{Radish}

\section{Write for Special Prices in 100 and 1,000 Lb. Lots.}

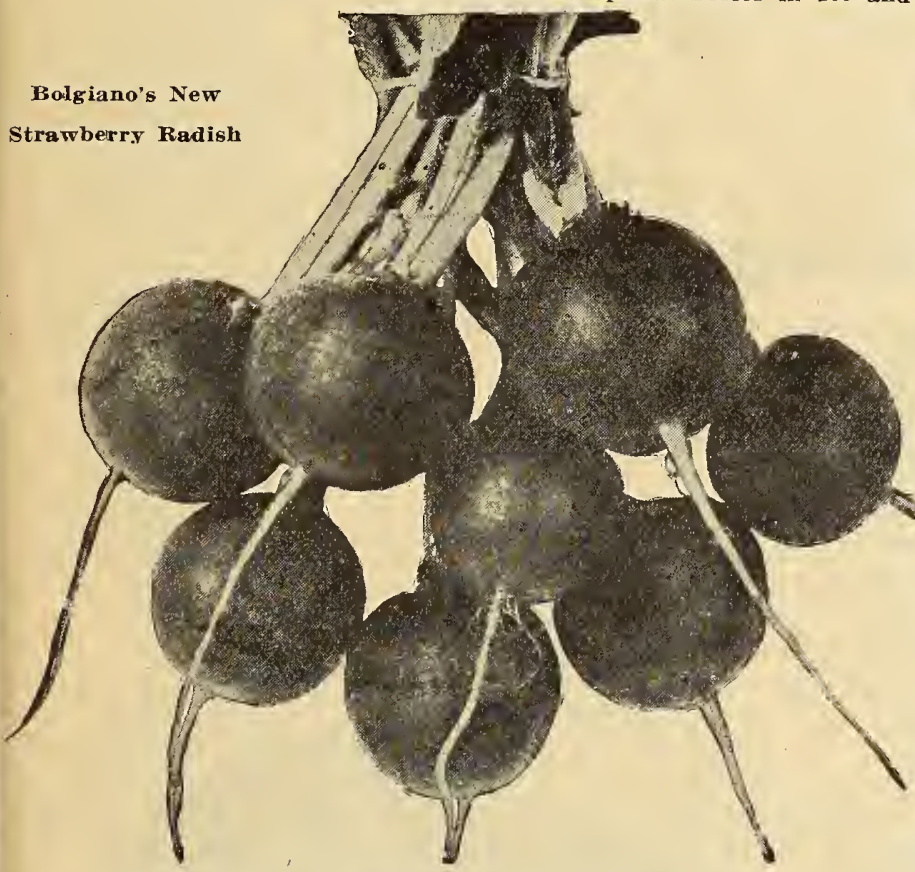

Extra Early Round Varieties

9. Tip Top White Tip. The beautiful New Extremely Early Radish. Pkts. $5 \mathrm{c}$ and 10c. $\mathrm{Oz}$ 10c. $1 / 1 / 4$ Lb. $25 \mathrm{c}$. 1/2 Lb* $40 \mathrm{c}$. Lb. $75 \mathrm{c} .5$ Lbs. at $65 \mathrm{c} 1 \mathrm{~b}$. Postpaid.

258. Strawberry Radish. This is the extremely early round Radish that attracted so much attention when we first introduced it by sample packages to our Market Garden customers. Pkts. 5c and 10c. Oz. 10c. 1/4 Lb. $25 \mathrm{c}$. 1/2 Lb. 40e. Lb. 75e. 5 Lbs. at 65e lb. Postpaid.

230. Ruby King, Bolgiano's Extra Early Radish. The best of all brilliant red Radishes. Pkts. $5 \mathrm{c}$ and $10 \mathrm{c}$. Oz. 10c. 1/4 Lb. 25c. 1/2 Lb. 40c. Lb. 75 e. 5 Lbs. at 65 e $1 \mathrm{~b}$. Postpaid.

248. Bolgiano's Solid Crimson King. Double the size of the ordinary carly turnip-shaped Radishes, this one often measuring 6 to 7 inches in circumference; the shape varies between round circumference; the shape varies between round Lb. 40c. Lb. $75 \mathrm{c}$. 5 Ijbs. at $65 \mathrm{e}$ 1b. I'ostpaid.

239. Scarlet Turnip White Tip Radish. Round, bright scarlet, attractive white tip, matures in 25 days. Pkts. 5e and 10e. Oz. 10c. 1/4 Lb. 20c. 1/2 Lb. 35e. Lb. 60e. 5 Lbs. at $50 \mathrm{e} 1 \mathrm{~b}$.

538. Rosex Gem. Everybody wants this prett5 crisp' tasty little French Rarlish, so showy with its brilliant cardinal red, contrasted with its immaculate white. Pkts. 5e and 10e. Oz. 10e. 1/t Lb. 20e. Lb. 60e. 5 Lbs. at $50 \mathrm{c} 1 \mathrm{~b}$.

500. Early Snowball. Foreing White Turnip Radish Larliest, round, white, solid. Pkts, 5c and 10c. Oz. 10c. 1/4 Lb. 20c. Lb.65e. 5 Lbs, at $55 \mathrm{e} 1 \mathrm{~b}$

235. French Breakfast Radish. Quick growth, mild, tender, good for forcing. Pkts. 5e and 10e. Oz. 10e. $1 / 4$ b. 20c. Lb. 65c. 5 Lbs. at $55 \mathrm{c} 1 \mathrm{~b}$.

246. Tait's Tavorite Forcing Extra Early Radish. For forcing under glass. It is also largely used for field culture. Perfect both in shape and color, the skin being a bright, transparent red, and many bunches may be put in bright, transparent red, and many bunches may be put in a single package. Pkts. 5

370. New Sparkler White Tip Red Radish. Pkts. 5c and 10c. Oz. 10c. 1/4 Lb. 20c. 1/2 Lb. 35c. Lb. 65c. $5 \mathrm{Lbs}$ at $55 \mathrm{c} 1 \mathrm{~b}$.

238. Bolgiano's Round Scarlet Globe Radish. Rich, scarlet color, faultless shape, matures in 20 days. Pkts. $5 c$ and 10c. Oz. 10c. $1 / 4 \mathrm{Lb}, 20 \mathrm{c} .1 / 2 \mathrm{Lb} .35 \mathrm{c}$. Lb. 65e. $5 \mathrm{Lbs}$ at $55 \mathrm{c}$ ib.

241. Vick's Scarlet Globe Radish. A leader among bright, round, red Radishes. Quick maturing, extremely attractive, short tops, solid and fine flavor. Pkts. 5c and 10c. Oz. 10c. 1/1 Lb. 20c. Lb. 65c. 5 Lbs. at 55c ib.

232. Lexington Market Money Maker. The best early, 232. Whington Market Money Maker. The best early,
round, white turnip Radish. Pkts. $5 \mathrm{c}$ and 10c. Oz. 10c. round, white, turnip Radish. Pkts. $5 c$
$1 / 4$ Lb. 20 c. Lb. 65 c. $5 \mathrm{I}$ bs. at $55 \mathrm{c}$ ib.
240. Crimson Giant Globe Radish. Originator's Stock Seed. This is an entirely ner rariety, suitable for forcing or early ourdoor planting. Plits. 5c and 10c. Oz. 10c. 1/4 Lb. $20 \mathrm{c}$. $1 / 2 \mathrm{Lb}$. 35c. Lb. 65e. 5े Lbs. at $55 \mathrm{c} 1 \mathrm{~b}$.

2341/2. Bolgiano's Early White Olive Radish. It has short tops, rapid growth, perfect olive shape, extra fine quality. Pkts. $5 \mathrm{c}$ and 10c. Oz. 10c. 1/4 Lb. 20c. 1/2 Lb. 35e. Lb. 65c. 5 Lbs. at $55 \mathrm{c} 1 \mathrm{~b}$.

231. Fe'ton's Model or Philadelphia White Rox Radish. Handsome and early with ferrer short leaves, hence can be sown thickly in the row. Pkts. 5c and 10c. Oz, 10c. 1/4 Lb. 20c. $1 / 2$ Lb. 35e. Lb. 65e. 5 Lbs. at $55 \mathrm{c} 1 \mathrm{~b}$.

509. Prussian Globe Radish. It is a GLOBE shape of a crimson color, short top alld will stand forcing. Pkts. 5e and $10 \mathrm{c} .0 z .10 \mathrm{c} .1 / 4 \mathrm{Lb} .20 \mathrm{c}$. 1/2 Lb. 35e. Lb. $65 \mathrm{c} 5 \mathrm{Lbs}$. at $55 \mathrm{c} \mathrm{lb.}$

468. Scarlet olive Shaped Radish. Pkts. 5c, Oz. 10c. 2 Ozs. 15c. 1/4 Lb. 20c. 1/2 Lb. 35c. Lb. 65e. $5 \mathrm{Lbs}$ at $55 \mathrm{c} 1 \mathrm{~b}$. 469. Extra Early Deen Red Turnip. Pkts. 5c. Oz. 10c. 2 Ozs. 15c. $1 / 4$ Lb. $20 \mathrm{c}$. $1 / 2$ Lb. 35c. Lb. 65c. 5 Lbs. at $55 \mathrm{c} 1 \mathrm{~b}$. 


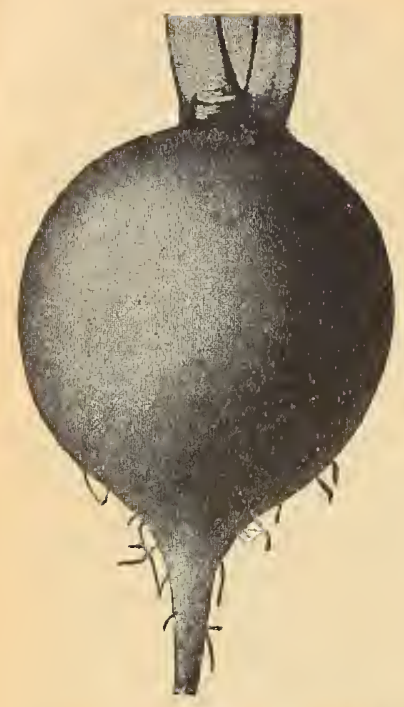

Solid Crimson King Radish

244. Giant White Stuttgart. L.b. 65c. 5 Lbs. at $55 \mathrm{c} 1 \mathrm{~b}$.

247. Chartier or Shepherd. $5 \mathrm{Ibs}$, at $60 \mathrm{c}$ lb.

\section{RADISH - Early Long Varieties}

25.5. Improved Early Long Scarlet short Top. Whe hinest strain of the most popular Radish. The long, slender, handsome red roots are most attractive. They are ready in about 25 days. Crisp, brittle and of choicest quality. Length 5 to 6 inches. Pkts. $5 \mathrm{c}$ and 10c. Oz. 10c. 1/4 Lb. 20c. $1 / 2$ Lb. 35c. Lb. $65 \mathrm{c}$. 5 Lbs. at $55 \mathrm{c} 1 \mathrm{lb}$.

250. Bolgiano's New Long Red Glass Radish. Pkts. 5c and 10c. Oz. 10c. 1/a Lb. $25 \mathrm{c}$. $1 / 2$ Lb. 40c. Lb. 75 c. 5 Lbs. at $65 \mathrm{c} \mathrm{lb.}$

252. Cincinnati Market. A strain of the Long Scarlet; growing to slightly larger size. Pkts. 5e and 10c. Oz. 10c. 1/4 Lb. 20c. 1/2 Lb. 35c. Lb. 65e. 5 Lbs. at 60e lb.

537. Woods' Larly Frame. This is an extra early strain of the Long Searlet Short Top. Pkts. 5e and 10c. Oz 10c. 1/1 Lb. 20c. 1/2 Lb. 35c. Lb. 65e. 5 Lbs. at 60c lb.

249. White Pearl Forcing. Bolgiano's Fxtra Early Long Radish. Sweet, crisp flavor, Pkts. 5c and 10c. Oz. 10c. 1/4 Lb. $25 \mathrm{c}$. 1/2 Lb. 40c. Lb. 75c. 5 Lbs. at 65c lb. Postpaid. 257. New White Icicle Kadish. Introduced from Europe, is one of the finest and longest of the rery earlp. pure white varieties. Pkts. 5c and 10c. Oz. 10c. 1/4 Lb. 25c. $1 / 2$ Lb. $40 \mathrm{c}$. Lb. $70 \mathrm{c}$. 5 Lbs. at $60 \mathrm{c} 1 \mathrm{~b}$.

253. Lady Finger or White Vienna. Long white, very early, attractive. Plts. 5c and 10c. Oz. $10 \mathrm{c}$. 1//4 Lb. $25 \mathrm{c} .1 / 2$ Lb. $40 \mathrm{c}$. Lb. $70 \mathrm{c}$. 5 Lbs. at $60 \mathrm{c} 1 \mathrm{~b}$.

251. Bolgiano's New White Delicacy. Beautiful form, exceptionally clear, bright, waxy appearance, exceedingly smooth, delicate, crisp and tender. It has short tops. Pkts. 5e and 10c. Oz. 10c. 1/4 Lb. 20c. Lb. 65e, 5 Lbs. at $55 \mathrm{c}^{\mathrm{c}} \mathrm{lb}$.

557. Half Long Deep scarlet. Very popular in the New Orleans Market. Tbe Radisbes are of slightly larger diameter and most brilliant scarlet coloring. Pkts. 5c and 10c. Oz. 10c. 1/4 Lb. 20c. $1 / 2$ Lb. 35c. Lb. 65c. 5 Lbs. at 55e 1b.

470 . Long Cardinal or Brightest Long Scarlet. Pkts, 5e. Oz. 10c. 2 Ozs. 15c. 1/4 Lh. 20c. $1 \%$ Lb. $35 \mathrm{c}$. Lb. $65 \mathrm{c}$. $5 \mathrm{Lbs}$, at $55 \mathrm{c} \mathrm{c}$.

\section{Summer and Autumn Varieties}

254. New White Strasburg Radish. The most popular Summer Radish; of oblong shape, tapering to a point. Skin and flesh are pure white, almost transparent; very tender, of a delightful pungent taste. Pkts. $5 \mathrm{c}$ and 10c. Oz, 10c. 1/1/ Lb. 25c. 1/2 Lb. $40 \mathrm{c}$ Lb. 75c. 5 Lbs. at 65e $1 \mathrm{~b}$.

243. Large White Globe Summer. Deliciously mild and sweet. Pkts. $5 \mathrm{c}$ and $10 \mathrm{c} . \mathrm{Oz}$.
$1 / 4$ Lb. 20c. Lb. 65c. 5 Lbs. at $55 \mathrm{c}$ lb. 10c. $1 / 4$ Lb. $20 \mathrm{c}$. Lb. 65c. 5 Lbs. at $55 \mathrm{c}$ lb.
An immense white Summer Radish. Pkts. 5c and 10c. Oz. 10c. 1/1 Lb. 20c. 1/2 Lb. 35c.

Long, crimson, tipped with white. Pkts. 5c and 10c. Oz. 10c. 1/4 Lb. 20c. Lb. 65e.

\section{Winter Varieties}

256. New Short White Chinese Winter or Celestial Radish. The best of all Winter Radishes. Pkts. $5 \mathrm{c}$ and 10c.

Oz. 10c. $1 / 4$ Lb. 25e. $1 / 2$ Lb. $40 \mathrm{c}$. Lb. $75 \mathrm{c}$. 5 Lbs, at $65 \mathrm{c}$ Ib. 242. Chinese Rose Winter. Pkts. 5c and 10c. Oz. 10c. Lb. 25c. $1 / 2$ Lb. $40 \mathrm{c}$. Lb. $75 \mathrm{c}$. 5 Lbs. at $65 \mathrm{c} \mathrm{lb.}$

259. Round Black Spanish Winter. Pkts. 5c and $10 \mathrm{c}$

Oz. 10c. $1 / 4$ Lb. 25c. $1 / 2$ Lb. $40 \mathrm{c}$. Lb. $75 \mathrm{c}$. 5 Lbs. at $65 \mathrm{c} \mathrm{lb}$

261. Long White Spanish Winter. Pkts. 5c and 10c.

Oz. 10\%. 1/. Lb. $25 \mathrm{c}$ 1/ Lb. $40 \mathrm{c}$. Lb. $75 \mathrm{c}$. $5 \mathrm{Lbs}$, at $65 \mathrm{c} 1 \mathrm{~b}$

\section{Plets., Ozs. and $1 / 4$ Lbs.
Delivered Frec.}

260. New Winter Radish Osaka. Pkts. 5c and 10c. Oz. 10c. $1 / 4$ Lb. 25c. $1 / 2$ Lb. 40 c. Lb. $75 c$ 5 Lbs, at $65 \mathrm{c} \mathrm{lb.}$

262. Kound White Spanish Winter. Pkts. 5c and 10c Lb. 25c. $1 / 2$ Lb. $40 \mathrm{c}$. Lb. $75 \mathrm{c}$. 5 Lbs. at $65 \mathrm{c} 1 \mathrm{~b}$ Oz. 10c. $1 / 4$ Lb. $25 c$. $1 / 2$ Lb. 40 c. Lb. 75 c. 5 Lbs. at $65 \mathrm{c} 1 \mathrm{~b}$. Rhubarb or Pie Plant

Victoria, A good market sort, stalks red. Pkts. 5e and 10c. Oz. 10c. $1 / 4$ Lb. 25c. 1/2 Lb. 40c. Lb. $75 \mathrm{c}$.

\footnotetext{
$10 \approx$. Bush Iarieties for 40 Hills; Large Seeded Varieties, 15 Hills; 2 to 3 Lbs. Bush; 3 to 4 Lbs. Large Seeded per acre.

Culture. Sow in hills in the same manuer and at the
}

\section{Bush Varieties}

331. Bolgianc's Extra Early Dawn Squash. The earliest and finest white Bush Squash Pkts $5 \mathrm{c}$ and $10 \mathrm{c} O \mathrm{Oz}$. 15c. $1 / 4$ Lb. 30c. $1 / 2$ Lb. 55 c. Lb. $\$ 1.00$. 5 Lbs. at $90 \mathrm{c} \mathrm{lb.}$ Postpaid.

501. New Extrad Early Jersey white Bush. An extra early strain of tbe White Bush. Pkt. 5c. Oz, 10c. 1/4 Lb. 25c. Lb. 85 c. 5 Lbs, at $75 \mathrm{c} 1 \mathrm{~b}$.

191. Long Island White Busl. An improved strain of Farly White Scallop Bush; rery prolific. Pkt. 5c. Oz. 10c. $1 / 1$ Lb. 30c. Lb. $90 \mathrm{c} 5$ Lbs. at $80 \mathrm{c}$ lb.

265. Extra White Bush Scalloped or Patty Pan Squash. Good size, uniform, a heavy cropper, and early. The skin is white and the flesh fine grained and tender. Pkt. 5c. Oz. 10c. $1 / 4$ Lb. $25 \mathrm{c}$. Lb. $85 \mathrm{c}$. 5 Lbs. at 5 5. $1 \mathrm{~b}$.

304. Mammoth or Giant Summer Crooknecl Squash. Double the size of the ordinary Crookneck and very warty, fine for market. Pkt. 5c. Oz. 15c Lb. 30c. $1 / 2$ Lb. 5je. Lb. $\$ 1.00$. 5 Lbs. at $90 \mathrm{c} 1 \mathrm{~b}$.

329. Fordhook Bush. Early, sweet and drs, oblong, bright yellow, one of the handsomest and best keeping Winter varieties. Pkts, 5e and 10c. Oz. 15c. 2 Ozs. $25 \mathrm{c}$. $1 / 4$ Lb. $30 \mathrm{c}$. Lb. $\$ 1.00$. 5 Lbs. at $90 \mathrm{c} 1 \mathrm{~b}$

\section{Running Varieties}

0. The True Hubbard Squash. Vines of stron running growth; fruits large, olive shape, witb dark grcen skin, very rich flesh. An excellent keeper and of splenclid quality. Pkt. 5e. Oz. 20c. 2 Ozs. 35c. 1/1 Lb. 60e. Lb. $\$ 2.00$. 5 Lb. at $\$ 1.90$ ib

330. Chicago Warted Hubbard. A sunerior strain of mammoth size with skin heavily warted. Pkt. 5r. Oz. $20 c .2$ Ozs. $25 \mathrm{c}$. $1 / 4$ Lb. 60c. Lb. $\$ 2.00$. Lbs. at $\$ 1.901 \mathrm{~h}$.

27t. Improved Winter Crookneck or Cushav Squash. Mottled green and white; flesh is yellow. solir, fine grained and sweet; Pkt. 5c. Oz. 15c. $1 / 4$ Lib. 30 c. $1 / 2$ Lb. 55 c. Lb. $\$ 1.00 .5$ Lbs. a 90 c 11)

Boston Marrow

Squash

267 1/2. Mammoth White Busl Scalloped. Pkt. 5̄c. Oz. 10c. $1 / 4$ Lb. 25c. Lb. 85c. 5 Lbs. at $75 \mathrm{c} 1 \mathrm{~b}$

271. Early Yellow Bush Scalloped. A very early, fiat a. 10c. $1 / 4$ Lb. 25 c. $1 / 2$ Lb. 15 c. Lb. 80 c. 5 Lbs. at $70 \mathrm{c} \mathrm{lb}$ 211. Mammoth Yellow Bush Scalloped or Golden Custard. Similar to Early Yellow Busb, but very much larger. A splendid variety, very prolific and a good seller. Pkt. 5c. Oz. 10c. 1/1 Lb. 25c. Lb. 85̄c. 5 Lbs, at 75c $1 \mathrm{~b}$.

269. Golden Summer Crookneck Squash. of dwarf bushy habit, very productive; skin yellow; flesh greenishrellow color, dry and agreeable flavor. Pkt. 5c. Oz, 10c. 1/1 Lb. $30 \mathrm{c}$. $1 / 2$ Lb. $55 \mathrm{c}$. Lb. $\$ 1.00$. 5 Lbs. at $90 \mathrm{c} 1 \mathrm{~b}$.

272. Early Prolific Orange Marrow. A very early, prolific Boston Marrow of most delicate flavor and uniform type. Suitable for Fall or Winter. Pkt. 5c. Oz. 10c. 1/4 Lb. $25 \mathrm{c} .1 / 2 \mathrm{Lb}$. 40c. Lb. $75 \mathrm{c}$. 5 Lbs. at 65c lb.

273. Boston Marrow. Oval, bright orange, flesh yellow. Plit. 5e. Oz. 10c. 1/4 Lb. 20c. 1/2 Lb. 35c. Lb. 60c.

270. The New Red or Golden Hubbard. Red, exceedingly slowy and attractire. Flesh mirch richer in color than

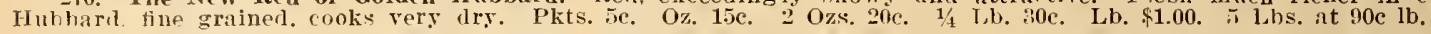


Wholesale Prices for Market Gardeners and Farmers-Fall, 1919.

39 PUMDKins s to 10 feet apart eachway, 4 seeds in a hill; in other respects are cultivated in same manner as 102. King of the Mammoth or True Potiron. The Great Prize Pumpkin growing the largest of all, from 100 to 200 pounds in weight, bright yellow, tender, excellent. Pkt. 5c. Oz 10c. 2 Ozs. 15c. 1/1 Lb, $25 \mathrm{c}$ Lb. $75 \mathrm{c} 5 \mathrm{Lbs}$ at $65 \mathrm{clb}$

36t. Golden Oblong Pumpkin. Produces oblong, bright, orange colored fruits of good size, with rich colored flesh. Pkt. 5c. Oz. 10c. 1/4 Lb. $25 \mathrm{c}$. Lb. 85c. 5 Lbs. at $75 \mathrm{c} \mathrm{lb.}$ 136. Smail Sugar Pumplkin. Small orange colored, sweet. Pkt. 5c. Oz. 10c. 1/4 Lb. 25c. Lh. 85c. 5 Lbs. at $75 \mathrm{c} \mathrm{lb.}$ 1069. Connecticut Field or Large Yellow Pumpkin. Excellent for stock feeding. Plit. 5c. Oz. 10c. 1/4 Lb. 15c. Lb. $35 \mathrm{c}$. 5 Lbs. at $30 \mathrm{e} 1 \mathrm{~b}$.

10581/2. Kentucky Large Field. Flat, fine for Pumpkin pies, Winter, etc. Pkt. 5c. Oz. 10c. 1/1/ Lb. 15e. Lb. 35e. Lbs. at 300

225. Sweet Potato Pumpkin. Finest variety for table. Pkt. 5c. Oz. 10c. 1/4 Lh. 20c. Lh. 60c. 5 Lhs. at 50c lh. One Ounce to 100 feet of drill. 10 to $12 \mathrm{Lbs}$.

in arills for an acre. 25 to 35 pounds

broadeast for an acre.

Salsify or

Parcel Post Rates, see Page 3.

Culture. Sow as early as the ground can be worked in the Spring, in drills 12 inches apart, 1 iuch deep, and thin out to 6 inches to the row. Keep them free from weeds. Cultivate the same as Carrots nd Parsnips. Sow 8 to 10 pound

504. L\&re White. Pkts. 5c and 10c. Oz.

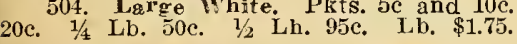

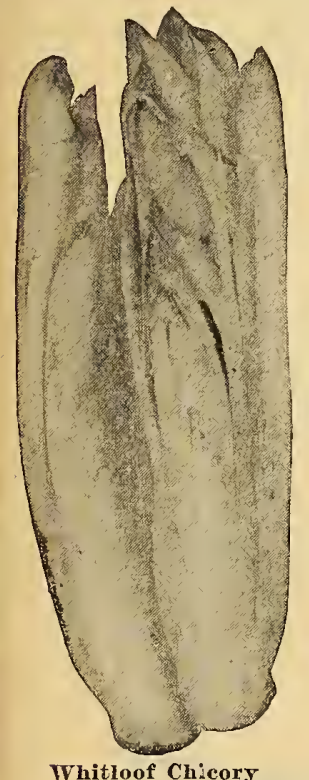

of Chicors French Endive

\section{${ }^{404}$ Whitloof Chicory, or French Endive}

404. Whitloof is used principally as a Winter salad, and it is most delicious served with French dressing and eaten like cos Lettuce. The seed should be sown in the open ground not later than Jume, in drills 12 to 18 inches apart, and the seedlings should be thinned out to stand not closer than three inches. The plants form long, parsnip-shaped roots which are lifted in the Fall, trimmed of leares and stored in soil in a cool place until wanted for forcing. The roots should be planted upright about $11 /$ to 2 inches apart in a roots should be planted deep. This will bring the neck of the root to within 9 inches of the level of the trench, which should be filled with light soil. If a quicker growth is desired, a mulch of fresh manure about two feet deep may be wed. The roots may also be forced in boxes in a warm eellar, in which case they should be set in fine soil two inches apart and with the crowns two inches below the surface. To exclude all light, the box should be covered with another of the same size, and if water is required it should be slightly heated. It requires ahout one month to force roots. The heads are then cut off with a small portion of the neck of the root attached. Pkts. 5c and 10c. $1 / 2$ Oz. $15 \mathrm{c}$. Oz. 30c. 2 Ozs. 55c. 1/4 Lb. 85c.

Lb. $\$ 1.60$. Lb. $\$ 2.25$.

\section{Kohl-Rabi}

152. "Best-of-All" Kohl-Rabi, Comhines the quality of the finest Great varieties. Round like an apple, fine, smooth skin. Leaves ver 7 few, stand erect, enabling grower to plant closer and helps him in bunching. Giant Flesh is unsurrpassed in tenderness and flaror. "Best-of-All" Kohl-Rabi will not run to seed in frosty weather. Equally valuable for forcing or Salsify open ground culture. Pkts. 5c and 10c. Oz. 25c. 1/4 Lb. $75 \mathrm{c}$. Lb. $\$ 2.50$.
117 . Earliest White Vienna. The standard well-known variety most largely used, fine stock. Pkts, 5c and 10c. Oz. 25c. 2 Ozs. 40c. 1/4 Lb.65e. Lh. \$2.00.

\section{Spinach}

1104. Curled Saroy or Bloomsdale, Imported. We grow many thousands of pounds of both the American and Imported seed each year. We helieve our private stock is the choicest it is possible to produce. We solicit your orders. Pkts. 5c and 10c, 1/4 Lb. 20c. 1/2 Lb. 30c. Lb. 50c. 1105 . Curled Leaf Savoy, or Bloomsdale. American Grown.

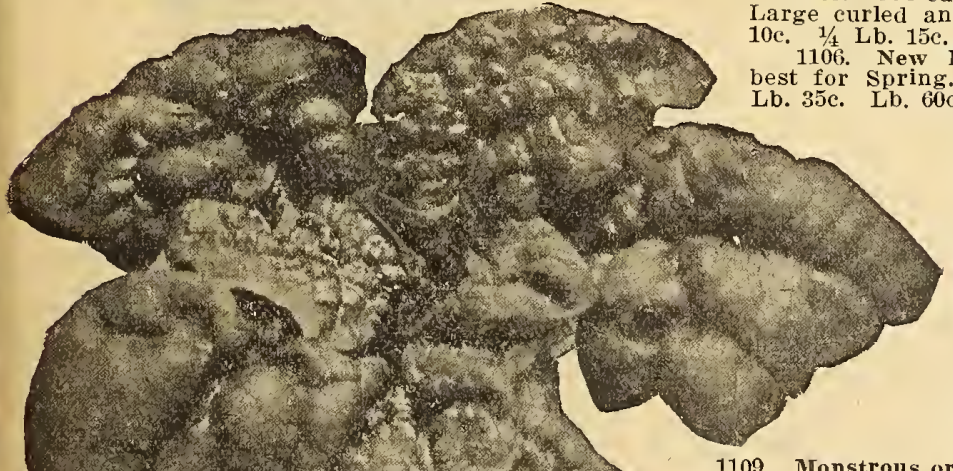
Lb. 60c. 5 Lbs. at $50 \mathrm{e}$ lb.
r Viroflay. A valuable variety; has large, round Pkts, 5c and 10e $1 / 1$ Lh, 20c, $1 / 2$ Lb, 35e Lb. $60 \mathrm{c}$ Lbs, at $50 \mathrm{c} \mathrm{lb}$.

1232. New Triumph Spinach This excellent new Spinach is nearly double the size of the Victoria and has all of its rood aualities. Very profitable for market gardeners and shippers. Pkts. $5 c$ and 10c. Oz. 10c. $1 / 1 \mathrm{Lb} 20 \mathrm{c}$ 1/2 Lb. $35 \mathrm{c}$ Lb. $60 \mathrm{c} 5 \mathrm{Lbs}$, at $50 \mathrm{c} \mathrm{lb}$ either so Early Giant Thick-Leaved. A new and superior Spinach plant sown in Spring for early Summer use or Fall for Winter use Bolgiano's Bipomsdale Curled Savoy Spinach 1107, the broad, dark oreen leaves are of the finest quality. Pkts. 5c and 10c. Oz. 10c.

1000. Long Season Spinach. This new variet $\mathrm{is}$ especially adapted for summer sowing before going to seed plts. $5 \mathrm{c}$ and $10 \mathrm{c}$. $10 \mathrm{c}$. $1 / 4$ Lh. $20 \mathrm{c} .1 / 2$ Lb. 35e. Lb. 60c. $5 \mathrm{Lbs}$

1108. Long Standing, Thick-Leaved Spinch. Inese are large, thick, fleshy and crumled, fully equal to the Savoy Leaf. Pkts. $5 c$ and 10c. Oz. 10c. 1/4 Lb. 20c. $1 / 2$ Lb.

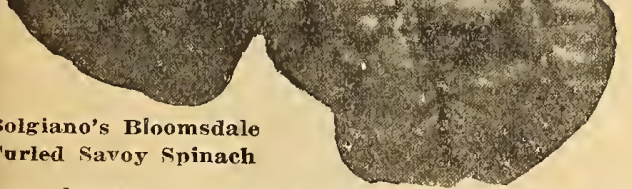

plant compact, growing with short stemmed, thick and fleshy rich green leaves. Pikts. 5c and 10c. Oz. 10c. 1/4 Lb. 20c. 1/2 Lb. 35c. Lb. 60c. 5 Lbs. at $50 \mathrm{c}$ 1b.

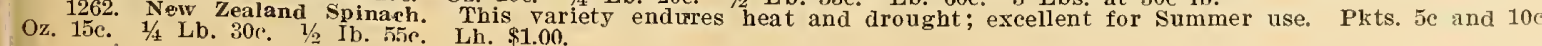




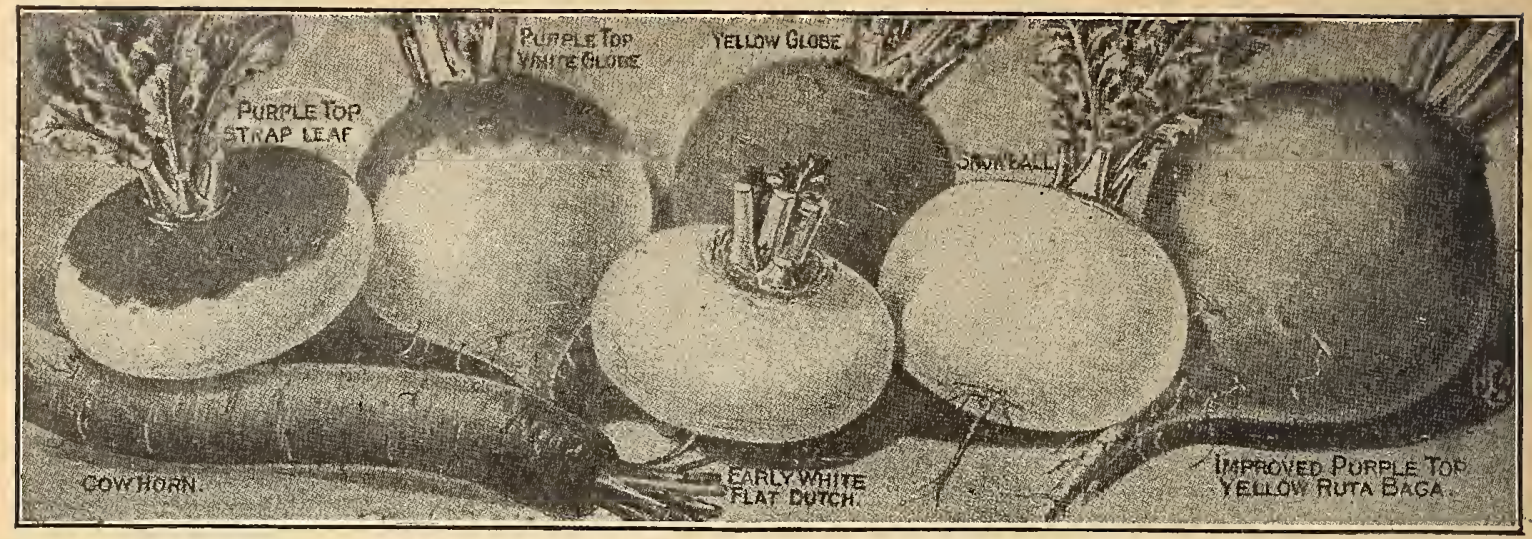

\section{Plets., Ozs. and $1 / 4$ Lbs. Delivercd Free. \\ Parcel Post Rates, see Page.2.}

\section{Write for Special Prices in 100 and 1,000 Lbs. Lots.}

313. Fed Top White Giobe. The handsomest and most salable Turnip. As a profitable sort for home or market it is unsurpassed. It is a large, rapid-growing sort, with globular shaped roots. Flesh pure white. The skin is white and purple, the under portion being white and the top bright purple. (See illustration.) On account of its shape it will outyield any other sort. Pkt. 5c. Oz. 10c. 1/4 Lb. 25e. $1 / 2$ Lb. 45 c. Lb. 85 c. 5 Lbs, at 75 c. 1 b.

314. Warly Red or Purple Top White Flat Strap-Leaf Turnip. This is one of the best table Turnips on the market. being fine grained and of mild flavor. It is white below, with a bright purple top; flesh white, leaves short, narrow and erect. Will mature in 8 or 9 weeks. A good cropper and an excellent keeper. Pkt. 5c. Oz. 10c. 1/4 Lb. 25c. Lb. 75c. 5 Lbs. at 65c. $1 \mathrm{~b}$.

315. Extra Early: Purple Top Milan. Earliest Turnip in cultivation; a week sooner than any other. Flat, smooth, of medium size, with bright purple top and few leaves. Flesh white and choice. Adapted to Spring or Fall. A good keeper. Pkts. 5c. Oz. 10c. 1/4 Lb. 45c. 1/2 Lb. 80c. Lb. $\$ 1.50$. $5 \mathrm{~L}$ bs, at $\$ 1.40 \mathrm{lb}$.

328. Large White Norfolk. It is allowed to stand out during the Winter in the South. Pkt. 5c. Oz. 10c. 1/4 Lb. 25e. Lb. 75 c 5 Lbs. at $65 \mathrm{c} 1 \mathrm{~b}$.
327. Ruta Baga Market Gardeners' Improved Purple Top. Our Ruta Baga is select, fields enormous crops of handsome, large, solid, yellow-fleshed Turnips; is grown largely for cattle food; keeps over Winter till Spring in good condition. Get our splendid stock, and the crops will satisfy and remunerate you. It is also used as a table regetable because of its sweetness. Pkts. 5c and 10c. Oz. 10c. $1 / 4$ Lb. 25 c. $1 / 2$ Lb. 45 c. Lb. 85 c. 5 Lbs, at $75 \mathrm{cl} 1 \mathrm{lb}$.

321. Southern Seven Top. Hardiest of all sorts, may be left standing in the open ground during Winter. In the Southern states it yields in the spring abundant foliage for boiling with cured meats and is only desirable for this purpose. Pkts. 5e and 10c. Oz., 10c. 1/1/ Lb. 15c. $1 / 2$ Lb. 25c. Lb. $45 \mathrm{c}$. $5 \mathrm{Lbs}$. at $35 \mathrm{c}$. $1 \mathrm{~b}$.

320. White Egg. Oval or egg shape, handsome and sweet: flesh firm and sound-grained, thin and perfectly smooth skin of snowy whiteness. Pkts. 5c and $10 \mathrm{c} . \mathrm{Oz}$. 10c. $1 / 4$ Lb. 25c. $1 / 2$ Lb. $45 \mathrm{c}$. Lb. $85 \mathrm{c}$. $5 \mathrm{Lbs}$. at $75 \mathrm{c} \mathrm{lb.}$

323. Early White Flat Dutch. Pure white, flat strapleaf Turnip. Early, medium size, excellent quality for early Spring sowing. Pkts. 5c and 10c. Oz. 10c. 1/4 Lb. 20c. $1 / 2$ Lb. 30c. Lb. 50c. 5 Lbs. at 40c. 1 b.

325. Pomeranian White Globe. Good either for table or stock. Very productive. Pkt. 5c. Oz. 10c. 1/4 Lb. 25 c. $1 / 2$ Lb. 40c. Lb. 75c. $5 \mathrm{Lbs}$. at $65 \mathrm{e}$ ib.

324. T'urple Top Yellow Aberdeen. Medium size, round, flesh pale yellow, tender and sugary. The plant is hardy, productive and keeps well. Plit. 5c. Oz. 10c. $1 / 1$ Lb, 20c. $1 / 2$ Lb. 30c. Lb. 50c. 5 Lbs. at $40 \mathrm{c} \mathrm{lb.}$

316. Yellew Globe. Yellow Globe is a wonderful cropper, and keens far into the following vear. It begins to bulb at the very start and forms large-sized roots and small tops. Pkt. 5c. Oz. 10c. start and forms large-sized roots and small tops.

530 Southern Prize or Dixie. Makes large, round, white Turnips in addition to salad; hardy and needs no protection, the most popular Winter and Spring Salad Turnip grown. Pkts. 5e and 10c. Oz. 10c. $1 / 1$ Lb. 15c. 1/2 Lb. $25 \mathrm{c}$. Lb. $45 \mathrm{c}$. 5 Lbs. at $35 \mathrm{c}$ lb.

159. White Top White Globe Strap-Leaf. Of a perfect globe shape, about six inches in diameter, with smooth, all pure white skin: flesh snowy white, firm and erisp, and of quick growth. A $75 \mathrm{c} .5$ Lbs. at $65 \mathrm{c} 1 \mathrm{~b}$.

322. Large Amber Globe. Flesh yellow, fine grained and sweet; hardy, keeps well, a good cropper. Very popurar in the South. Pkt. 5c. Oz. 10c. 1/4 Lb. 20c. 1/2 Lb. 30c. Lb. 50c. 5 Lbs. at $40 \mathrm{c} 1 \mathrm{~b}$.

319. Sweet German. Should be sown a month earlier than flat Turnips. Pkt. se. Oz. 10c. 1/4 Lb. 25c. Lb. 85c. J Lbs. at T5e 1 b.

326. Cow IIorn. A white Turnip of peculiar long shape and quick maturity. It wrows to a large size, standing half out of the rround. Pkts. 5e and 10c. Oz. 10c. $1 / 4 \mathrm{Lb}$. $25 \mathrm{c}$. Lb. $85 \mathrm{c}$. $5 \mathrm{Lbs}$. at Tround.

317. Golden Ball, orange Jelly or Robertson's. Flesh sweet and firm. Pkt. 5c. 0\%. 10c. 1/1/ Lb. 20c. Lb. 60c. 5 Lbs. at 50c $1 \mathrm{~b}$.

318. Yellow Stone. Flesh crisp, tender, of fine quality. Pkt. 5c. Oz. 10c. 1/1 Lb. 20c. 1/2 Lb. 30c. Lb. 50c. 5 Lbs. at $40 \mathrm{c} 1 \mathrm{~b}$.

509. Lon white French. Flesh hard, crisp. Pkts. 5c and 10c. Oz. 10c. 1/1/4 Lb. 25c. 1/2 Lb. 45e. Lb. 85e. 5 Lbs. at $75 \mathrm{c} 1 \mathrm{lb}$.

305. Extra Early White Milain. Extra early, tender and delicately flavored; the bulb is of medium size, verr handsome, smooth and of lear ivory-white both inside and out. Pkt. 5c. Oz. 15c. 1/4 Lb. 45c.

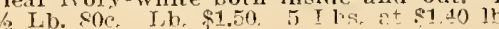

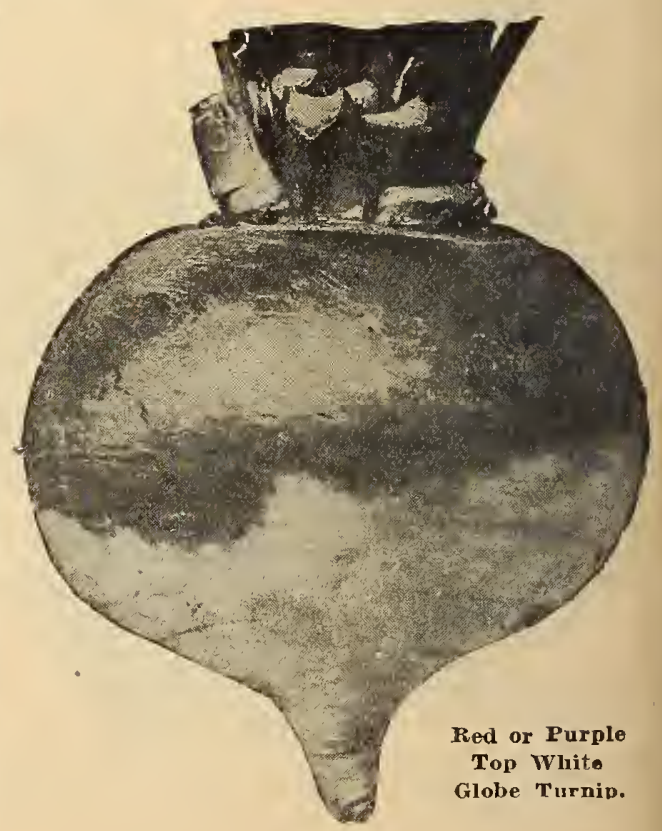




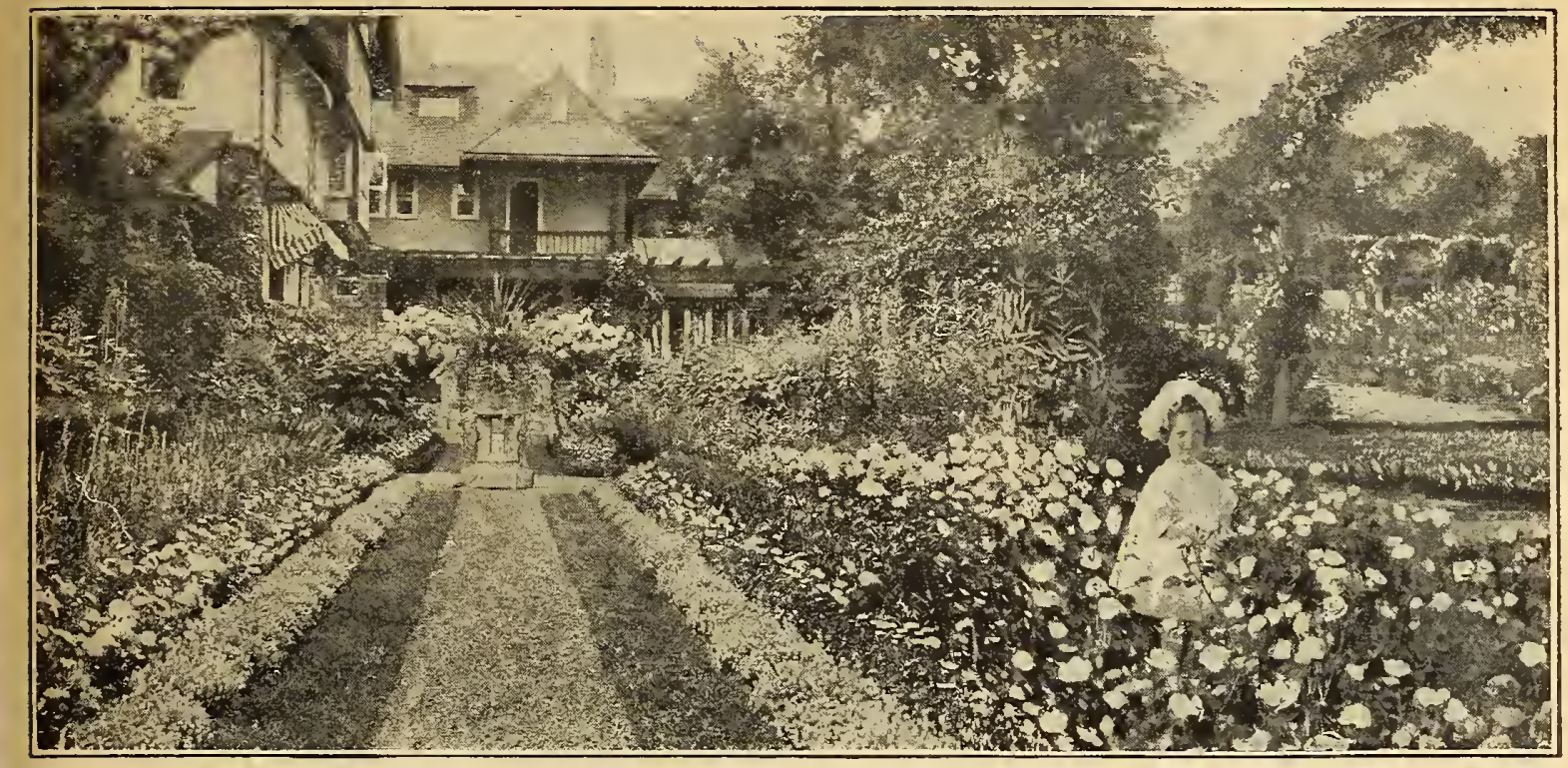

\section{Bolgiano's Dependable Flower Seeds Hardy Perennials for Fall Planting}

Very Large Packets, 5c Each, 6 for 25e. Mammoth Packets 10c Each, 4 for 25c. Parcel Post Rates, see Page *

Culture Directions Printed on Each of Our Flower Seed Packets. With This Help You Are Sure of Success.

Planted early this fall the plants mill get a good start before winter and will bloom luxuriantly early next summer, thus saving a whole year. Sow in fine, well-pulverized soil; cover the seeds not more than four times their size and press down firmly with a hoard.

1. Abutilon. Flowering Maple. Elegant flowering perennial shrubs, of strong growth and easy cultivation, free tlowering with variows colored beautiful drooping towers.
Considered indispensable for flowering indoors during the IIinter and Spring months and useful for bedding out in the Summer. Plits, jo, $10 \mathrm{c}$ and $25 \mathrm{c}$.

8. Agrostemma. Rose of Hearen. Coronaria. An attractive free flowering, hardy perennial of easy eulture producing glowing crimson flowers like a single piuk and silver-white foliage; blooms the first season: fine for curtting; 2 feet. Pkts. 5̇c and 10c. Oz. 25

10. Alyssum. Saxitale. Flowers golden-yellow; desirable for rock "rolk. Showy iu masses. Hardy perennial. Pkts. 5c, $10 \mathrm{c}$ and 25c. Oz. Juc.

15. Antirrhinum. Snay Dragon. Beautiful spikes of gaily colored flowers. They are one of the best cut flowers whick can be grown rom seed. While for beds or borders they are a pleasure, being in flower all the time if placed in a suuny position. Pkts. 5c and 10c. 1/4 Oz. 25c. Oz. 75c.

63. Canterbury Bell. Campanula Medium. Handsome, hardy biennial of stately growth, rich color and profuse bloom. Has large bell-shaped flowers, are effective in rariois colors. Height two to four feet. Pkts. 5c nd $10 \mathrm{c}$. $1 / 4$ Oz. $15 \mathrm{c}$. dens, compact bushes for permanent borders and garfeet, splendid cut flomers, 76. Cineraria. Hybrid Grandifiora. Choicest mixed for the window box. Conserfatory: large flowers from 2 to 3 inches across. ra rious color.s bolue in profusion in the Spring. Pkts. $5 \mathrm{c}$. $10 \mathrm{c}$ and $25 \mathrm{c}$.

78. Clematis. Well-known climber. some of the rarieties being remarkable for the size and beauty of their blossoms and others for their grarefulness: fine for covering arbors. verandas, etc. as they cling to almost any object. Pkts. $\bar{x}$ c. $10 \mathrm{c}$ and $25 \mathrm{c}$. Oz. 50c.

S6. Coreopsis. Lancelota Grandiflora. Harvest Moon. One of the finest. hardiest garden plants grown, forming bushes 2 to 3 feet high bearing quantities of long-stemmed large, single. vellow flowers throughont the Summer. Pkts. $10 \mathrm{c}$ and $25 \mathrm{c}$. Oz. $50 \mathrm{c}$

93. Dahlia. Extremely large flowers. Double mixed. Perennial. Will flower the first season if sown early. 4 to 6 feet. Pkts. 5c. $10 \mathrm{c}$ and $25 \mathrm{c}$ 1/4 Oz. 35c. Oz. $\$ 1.25$. and single hybrid. Finest mixed colors. Among our best nlants for mixed borders, prodincing snikes of flowers. Plets. 5c. 10c and 25c. 1\% Oz. 35c. Oz. 60c.
97. Dianthus. Hard $\mathrm{r}$ perennial Pinks. Pheasant's Eve Pink. Push plants of large fragrant blossoms. Pkts. 5ye Pink. Bush plants of large fragrant blossoms. Pkts. 5c, 100 . Disitalis. Fox Glove. Finest mixed colors. Hardy perennial of eass cult nre. producing long spikes of tubular
flowers. 3 to 5 feet. Phts. 5c. $10 \mathrm{c}$ and $25 \mathrm{c}$ Oz. $60 \mathrm{c}$.
106. Erysimum. Perofskianum. Flowers fragrant, bril liant orange and very showy in beds, borders, and on rockdisplay, and in early Autumn for spring decoration. Plst.

108. Feverfew. Matricaria. A free-flowering. half hardy, peremnial plant growing 15 inches in height. Seef sown early in Spring in the open ground will produce fown early in spring in the open ground will produce dowers by early Fall. Has double pure white towers onehalf inch in diameter, and produced in large clusters on a
long stem: fine for cutting. Pkts. 5c, 10c and 25c. Oz. 40c. and $25 \mathrm{c}$. Oz. $40 \mathrm{c}$.

110. Gaillardia. Grandiflora, Mexican Blanket Flower. Hardy perennial. Large, gay colored, double flowers. Use ful for cutting. The colors brilliant golden-yellow, crim 111. Gaura. Lindhermeri. A raceful perennial. 3 to + feet high. bearing numerous spikes of rost white flower from July till frost. This plant is largely used throughout Europe for interspersing in beds of Begonias, Geraniums, etc., giving an air of grace to what would otherwis be stiff and formal. Pkts. $5 \mathrm{c}$ and $10 \mathrm{c}$. Oz. 15c.

121. Tollyhock. Double Superb. Mixed. Farorite hardy plants, Tith immense flowers on spikes from 4 to 6 inches high. Bolgiano's strain of Double Hollyhocks are famous for beauty and coloring. Pkts. 5e, $10 \mathrm{c}$ and $25 \mathrm{c}$ Oz. $\$ 1.20$ Lantana. Finest mixed colors. Tender perennial Flowering continuously. Suitable for pot culture in Winter or garden in Summer; 2 to 3 feet. Pkts. $5 \mathrm{e}$ and $10 \mathrm{c}$ Oz. $50 \mathrm{c}$.

132. Lathyrus. Latifolius. Hardy Everlasting Peas These climb 6 to $\&$ feet high when trained on a trellis the fiwers are borne in large clusters and very closely re sembles Sweet Peas. They are peculiarly adapted to rotigl places. to scramble over rocks and bushes: splendid
flowers. Mixed colors. Pkts. 5c, 10c and 25c. Oz. 60c.

188. Pentstemon. Beard Tongue. Highly useful and attractive perennial, and much used in the hardy border Mixed. A great rariety of colors. Pkts. 5c. 10c and $25 \mathrm{c}$. liam has been esteemed as one of the finest of our harly garden plants, of easy culture, thriving in any good garden soil and lasting for years. The plants grow about 1 foot hich and form fine clumps. Our perfection strains produce heads of fragrant flowers, including blood-crimson, salmon pink. White. cerise. etc. Many have large white eses. and all being sweet scented, Pkts. 5c. $10 \mathrm{c}$ and $25 \mathrm{c}$ Or. 35c. either for bedding. vases or not nlant: a most striking ornamental Auttrmn Plant: valuable for shrubheries. flower borders or beds: Iarge spikes of orange-scarlet flowers: 3 to 4 feet. Pkts. 5c, 10c and 25c $1 / 0$ Oz. 50. Oz. $75 \mathrm{c}$.

215. Statice. Sea Tavender. Splendid hardy perennials for the border or rocker. producing all Summer panicles of minute flowers which can be dried and used for Winter bouquets. Mived rarieties. Pkts. $5 \mathrm{c}, 10 \mathrm{c}$ and $25 \mathrm{c}$.

231. Wallfower. Finest Mixed. An old farorite garden flower. The large massive. spikes of the Walfower are very conspicuous in the beds and borders atid useful in mak ing bouquets. Height about $11 \%$ feet. Pkts. 5c, $10 \mathrm{c}$ and $25 \mathrm{c}$ 


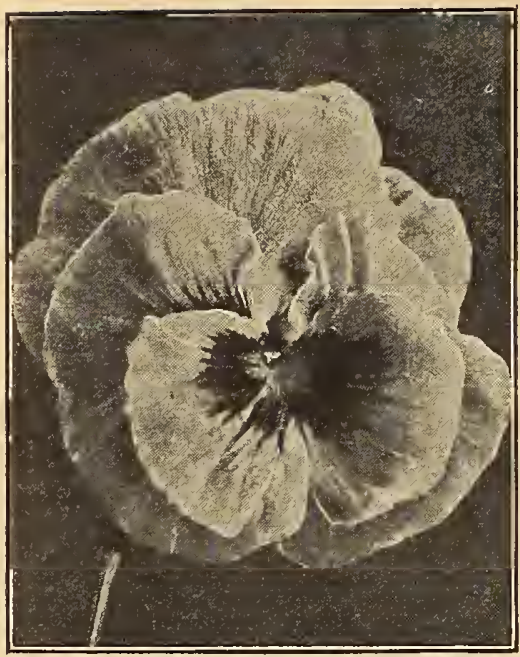

Bolgiano's Giant Flowered Pansies
Pkts., Ozs. and $1 / 4$
Lbs. Deivered Firee. Bolgiano's Giant Pansies Parcel Post Rutes,
see Page 2. PANSY CULTURE

For spring phants the seed may be sown broadcast from July to September. Cover the seed very lightly with fine soil and press in with board; then mulch the seed bed with long, loose, strawy manure, to a depth uf 3 or 4 inches. The seed will be up in about 10 lo 15 days; the a remove the straw a litile at a time. Trumsliant the seedlungs to beds or frames in September or October, and af er a shazp i-ost, late in Norember or early December. provide is light or loose muleh of hay, straw or litter. The seed maly alow be sown indoors in January or Fehririry; or in spring iu the open gronnl, in a shady, coul spot where the plant can be protected trom the strong inid-day sun. The soil should be very rich and liberal applications of bone meal should be given from time to time.

\section{IARGE $\tilde{x}$ PACKAGES, ANY YARIETY, FOR 25e POSTPAIN} The Most Beautiful Pansies in the World

170. Giant Adowis Pansy. None among the thousands of Pansy plants that we sold last spring attracted quice so much attention as this beaty ; it is a beautiful light blue contrasterl with white. Pkts. 5c, 10c and 2oc. Oz. $75 \mathrm{c} .1 / 4$ Oz. $\$ 1.25$

171. Giant Bridesmaid Pansy. I leautiful new Pansy, white shining ose, beautifully blotehed, I'kts. $5 \mathrm{c}, 1 \mathrm{cc}$ and $25 \mathrm{c}$. 1/8 $0 \mathrm{z} .50 \mathrm{c}$. 1/4 Oz. 90c.

173. Giant Empere Wil iam. Blue with violet eye. I new and ideal

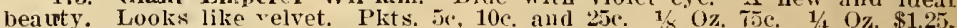

178. Giant Ruffled "Masterpiece" Imperial. German exhibition Pansies. A new class of blotched, heavily ruffed Pansies with large blooms, mostly undulated or curled, many fine ricll colors. Very popular. Pkts. 5e, $10 \mathrm{c}$ and $25 \mathrm{c}$. 1/8 Oz. \$1.010. 1/1 Oz. \$1.60.

179. Mme. Perret. A new and beautiful strain, originated with a French specialist: flowers of large size, horne very freely in great diversity of colors: especially rich in red and wine shitles. Pkts. 5e, 10e and 25c. $1 / 8$ Oz. 50e. 1/4 Oz. T5e. 175. Giant Golden Yellow With Large Black Eyes. One of the most

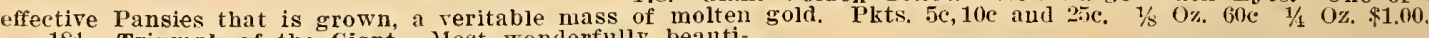

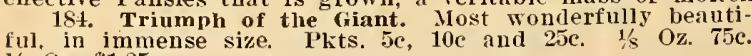
$1 / 4$ Oz. $\$ 1.25$.

185. Trimalrdeau Parisian Large stained. Very beautiful improved strail of Trimardeat Palnsies, mostly white ground and finely blotehed varieties. Pkts. 5c, $10 \mathrm{c}$ and $25 \mathrm{c}$. $1 / 8$ Oz. $35 \mathrm{c} .1 / 4 \mathrm{Lb}, 50 \mathrm{c}$.

186. Bolriano's Magnificent Finest Mixed Giant Show Pansies. This mixture, full of startling beauties, is so wel known that a description is hardly necessary; if you want a perfect lream of beauty, tri this mixture. Pkts. 5e, 10e and $25 \mathrm{c} .1 / 8 \mathrm{Oz}$. 35c. Oz, \$2.00.

176. Giant ciolden Queen. Pure golden-yellow aud tive-spotted. Pkts. Je, $10 \mathrm{c}$ and $25 \mathrm{c}$. 1/5 Oz. $75 \mathrm{c}$. $1 / 4 \mathrm{Oz}$. $\$ 1.25$. 17.. Giant Lord Beaconfield. It is certainly a Pausy that arrests the attention inmediately by its wondertul combination and its leatuty. I'kts. 5e, $10 \mathrm{c}$ and $25 \mathrm{c}$. $1 / \mathrm{s} 0 \%$. (i0c. $1 / 1$ Oz. $\$ 1.00$.

183. Superb Mixture of the Odier, Cassier and Bugnot strains. 'This is oue of the most beautiful and most costly mixtures of Pansies in the world. Pkts. 5c, 10e and $25 \mathrm{c}$. mixtures of Pansies in

\section{Bolgiano's Giant Orchid Flowering Countess Spencer Type Sweet Peas Parcel Post Rates, see Page 2.}

\section{PERTECT UREAUS OH BEAUTY}

A Large 5e package of the 15 Sweet l'eas listed on this page for 50c postpaid.

11. America Spencer. Striped brilliant carmine-red on white. Pkts. 5c, 10c and 25e. Oz. 35e. 1/4 Lb. $\$ 1.25$.

Apple Blossom spencer. Innense wared and crinkled flower's of carmine-ruse color with creamy blish wings. Pkts. 5c, 10c and 25e. Oz. 35e. 1/4 Lb. \$1.25.

Blanehe Ferry spencer. Pink and white. These beautiful contrasted colors in the large wavy standard and wings are a welcome addition. Flets. 5e, $10 \mathrm{c}$ and $25 \mathrm{c}$. Oz. $40 \mathrm{c}$. $1 / 4$ Lb. $\$ 1.35$

19. Helen Lewir spencer. The wings orange-rose; the standard is of an intense, rich erimson-orange, Blooms Lb. $\$ 1.25$

3. Senator spencer. The color is a varying combination of deep claret and chocolate striped and flaked on a ground of light heliotrope. Plits. 5e, 10c aud 25e. Oz. 35e. 1/4 Lb. $\$ 1.25$.

t. True countess spencer. The coloring is a soft rose-pink, which deepens at the outer edges and becomes still richer or more heavily suffused in cool weather. Pkts. 5e, 10c and 25c. Oz. 35c. 1/4 Lb. \$1.25.

White spencer. A pure wary white of enormons size and splendid substance. Pkts. 5r. 10c and 25c. Oz. 40c. 1/4 Lb. $\$ 1.35$.

\section{${ }^{24}$ The New Spencer Sweet Pea-Fiery Cross}

The Wonderful Now Spencer Sweet Pea that has Attracted so Much Attention the World over

Fiery Cross has all the appearance of live fire, the color being a scorching fire-red, or scarlet, without any shading and which scintillates and glitters in bright sunlight, thus adding a glowing, fire-like sheen which radiates over the flower. Vulike most of the orange-scarlet variefies, it does not scorch or burn even during extended periuds of intense sirnshiue, therefore it can be grown in all soils withont shading. The beautiful waved and fluted flowers are borne freely in threes ind tomrs, well placed on long, stout stems. Pkts. 10e and $26 \mathrm{c}$. O\% $75 \mathrm{~s}$. $1 / 4$ Lb. $\$ 2.50$.

22. The Gigantic Orchid-Flowered Sweet Peas, Countess Spencer Type vixed. This wouderful mixture contains only the rirest and most lovely Countess Spencer varieties, grown separately, then mixed in proper proportion so as to contain all varieties and colors. pkts. 5e and 10c. Oz. 20c. 1/4 Lb. 60e. Lb. \$2.25.

21. Bolgiano's Gorgeous Mixed of Best Ta!l or Grandiflora Sweet Peas. This wonderful combination of more than 75 distinct varieties uf New and Standard Sweet Peas makes it unequal for the vast range of color, both earliness, profusion of bloom and lateness of flowers. The gratifying and wonderful reports we annually receive from growers if our mixture as well as our own experiments permit us to clain we have the finest mixture of Standard Sweet Peas in the World. Pkt.

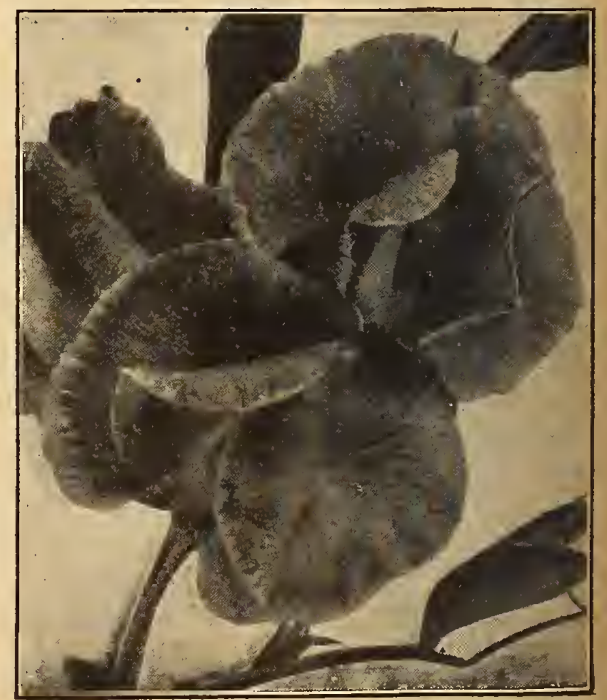

Giant Orchid Flowered Sweet Pea 
Wholesale Prices for Market Gar deners and Farmers-Fall, 1919.

\section{So-Bos-So Kilfly}

KEEPS THE ILIES AWAY FROM THE COW

INCREASES MILK PRODCCTION OVER 20 PER CENT

DON'T let yonr cors sntfer trom the corture of dies. When their energy is used to switch the flies from their backs they cannot give the maximun

niakes them irritated and rull down.

Spray the cow twice a day with SO-BOS-SU RILELY and the flies will not bother the cows while milking or while in the pastnre. Not injurions to skin. Will not anm the hair. Positire protection. I:
the most effective preventive

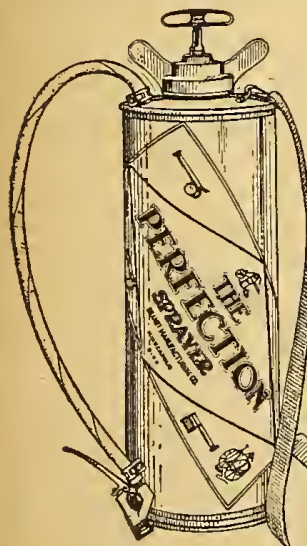
against the torture of flies known to chemical science. Has been nsed for over 17 vears in the Tnited States and foreign conn. tries Ptates and foreign connenough for 200 cows or tor on coll 100 days.
85c. Gial. $\$ 1.50$.

\section{Perfection Sprayer} Higliest Priced Sprayer in the World-and Worth It.

For spraying, disinferting or whitewashing ou plants, bnshes. rines, ete.

uade of heavier metal, with fewer parts, stronger in construetion. unore powerful in action. Tank $7 \pi / 2$ in. $\times 20$ in.. lock seated with 24 rivets. II lose attached with clamps. All furnished with automatic shut--off nozzels. Made of galvanized steel or solirl brass.

Price, galvanized steel $\$ 6.50$. Price, galvanized

LITTLE WONDER SPECLAL HANI NPRAY

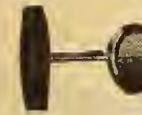

An ideal Sprayer in every respect; it has drip cup under spraying tubes to prerent dripping on carpets when used in hotse. Price 45e. Mailing weight, 3 lbs.

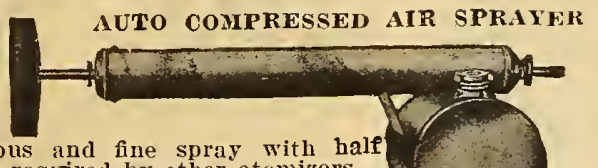

A continuous and fine spray with hate the pnmping required by other atomizers. window garden, for rose bushes and in the ponltry honse; will handle all solutions. insecticides and disinfectants. Made thronghout of stout material. Copper syphon tube, bronze ball valve plnnger, rod $1 / 4$-inch copper plated steel. Th solntion does not come in coutact with the pnmp' (yliuder. The spray may be adjusted by a slight turn of nozzle cap. Tin Pump and Galvanized Reservoir. Price $\$ 1.25$. Mililin's weight, $\ddot{3}$ lbs.

Junior Continuous Tin Sprarer................... \&

Junior Continuous Galvanized Sprayer............. 1.00

\section{BLACK IEAF 40}

The "sucking" iusects feed by inserting their" sharp, slender beaks into the interior of the leaf, blossom, etc. They cannot eat plant tissne, and therefore cannot eat poisons, hence must be destroyed with a preparation which kills by coming in contact with their bodies-in other words, by a "contact" insecticide "The most common sucking insects, with soft bodies, are the aphids (plant lice) thrios and leaf hoppers. They may be effectively controlled with "Black Leaf 40 ," a concentrated solution of nicotin: sulphate guaranteed to contain $40 \%$ of nicotine by weight. $10 \mathrm{z}, 25 \mathrm{c}$ 1/2 lb, $\$ 1.00$. 2 $1 \mathrm{bs} . \$ 3.25$. $10 \mathrm{lbs}, \$ 13,75$,

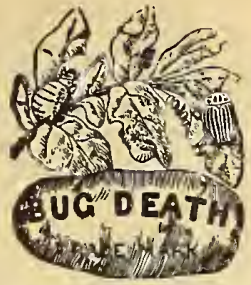

BUG DEATH

Bng Death kills Potato. Sqnash and Cucnmber liugs: Cnirant and Tomato Worms, anl all. Bngs and Worms thil. chew the leaves of the plants: non-por sonous. Directiolls for applying Ir'y Fol Potato and o.her vines which re quire a top application, apply dry with a shiker or sifter or porider spray at

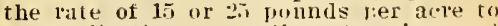
an application, accorling to size and condition ot the vines birections bo:
using in water. Ida 15 to 20 pounds to 80 gallons of water and wix thoroughly $1-10$ package 20c. 3-1b. package 50k. 5 -1b

SLUG SHOT (HAMHOND :)

A light, non-poisonous composite tine nowder for killing Potato Bugs. Currant and Cabbage Worms, Chicken Lire sow Bngs. Green and Black Fly, Beetles and Caterpillars. Not injurious or dangerons to persons or inimals. Easily distriluted by duster bellows. or in water by prayacre. 1 -1b. package 15c. 5-1b. vackage t5c. 100-1b. bbl., Sc per lb. PARIS GREEX

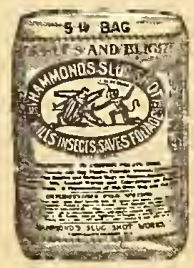

The chief merit of this article is the destruction of the P'otato Bng. It may be uses in liquid form. 1 pound in 50 gallons of water or with Land l'laster. at the rate of 1 pound Paris Green to 100 pounds Land Plister. 1/4 1b. 25. $1 / 2$ lb. toc. 11 lb. $65 \mathrm{c}$.

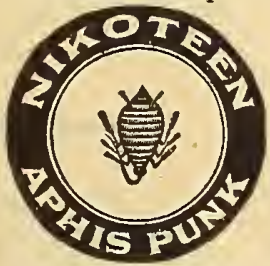

NIK(TTHEN

Roses, flowers, shrubs and plants of erers lind when sprayed with a brighter at once. The beneficial effect can harlly be exilggerited. If the NikOTLEN is used at all carefnlly. IF IROPliRti DILT'Tlis. most of the life-sucking plant lice are killed: sprasing slould be clone early in the real :111d while the inlay means a multiple of the original few anl a harder fight ahead. Price: 1 oz. 30c. 13/4 oz. J0c. 11 , $\$ 1.00 .11 \mathrm{~b} . \$ 1.75$

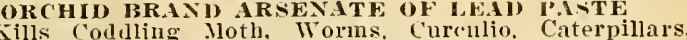
Potato Bugs liose pilgs and all chewing insects without Potato Bugs lose bings and all chewing insects without injury to foliage or buds, Directions: For all chewing insects lise 2 to $t$ ounces to a gallon of water. Add water
slowly till rubbed to a thin paste lofore idding to the rolume of water.

1-1b. package, per $1 b \ldots 35 e$ 5-1b. package, ver $1 \mathrm{~b} \ldots . .30 \mathrm{c}$ 50-1l. parcliage, per $1 \mathrm{~b} \ldots 25 \mathrm{c}$ 10-1b. package, per lb...26e | 100-1b. pkg. or 300-1b. bbi.

\section{ORCHID BRAND BORDEATX MIXTIRE POATE}

Recommended for Rust, Scab and all kiuds of Rot and other fnngous diseases. Should be userd on potatoes. Grape vines and all fruit trees. Directions: For Apple and Pear trees, 10 to 12 pounds to 50 gallous of water; Peach and I'lnm trees, 6 to 8 pounds to 50 gallons of water.

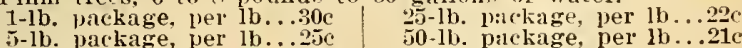
10-1b. package, per lo.

er..23c

100-1b. package, ver $1 \mathrm{~b} \ldots 20 \mathrm{c}$

ORCHID HRAND BORDEATX IRSENATE THAD IIXTURE PASTE

This is a combined Fungicirle and Insecticide specially recommended for Apple and Pear trees. i to $S$ pounds to 00 gallons of water, and stir. 1-lb. package, per lb...33c \begin{tabular}{r|r} 
5-lb. package, per $1 \mathrm{~b} \ldots .31 \mathrm{c}$ & $50-1 \mathrm{~b}$. package, per $1 \mathrm{~b} \ldots .28 \mathrm{c}$ \\
10-1b. package, per $1 \mathrm{~b} . .30 \mathrm{c}$ & $100-\mathrm{lb}$. package, per $1 \mathrm{~b} .26 \mathrm{c}$
\end{tabular}

25-1b. pisckige, per $1 \mathrm{~b} \ldots .29 \mathrm{c}$ DRY POWDER IRSENATE OF LEAD

One poland of Dry Arsenate of Lead eqnals three pounds of any paste Arsenate of Lead. lt mixes with water more readily than any other Arsenate of Lear. Stars in suspenion better, covers more thoroughly and sticks on the folige longer; no lumps, no sediment. no waste; simpler. cleaner and better in every particular. Hasily prepared for the spray tank. Price: $1 \mathrm{lb}, 60 \mathrm{c}, \overline{\mathrm{J}} \mathrm{lbs}, \overline{\mathrm{c}} \mathrm{c}, \mathrm{lb}, 25 \mathrm{lbs}$. $5 \mathrm{fc}$ lb. $50 \mathrm{lbs}, 53 \mathrm{c} 1 \mathrm{~b}$. $100 \mathrm{lbs}$. $50 \mathrm{c}$ ib.

\section{PYROX}

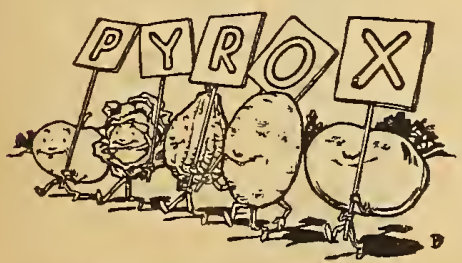

"Company front" brings out the best in the regiment."
The sreat combined insecticide and fungicide.

The loss caused by insects on fruit and truck crops in this oumtry earls year is over $\$ 100,000,000$.

The damage done by fungous diseases in this country each year is entimated to be fuily as great as that done by insects.

ly rox kilis all leaf-chewing insects and at the same time protects the crop against all fungous diseases.

Prices: $1 \mathrm{Lb}$, 4.ic $5 \mathrm{Lbs}, \$ 1.75,10 \mathrm{Lbs}, \$ 3.00,25 \mathrm{Lbs}, \$ 6.25,50$ bs. $\$ 11.00$. 


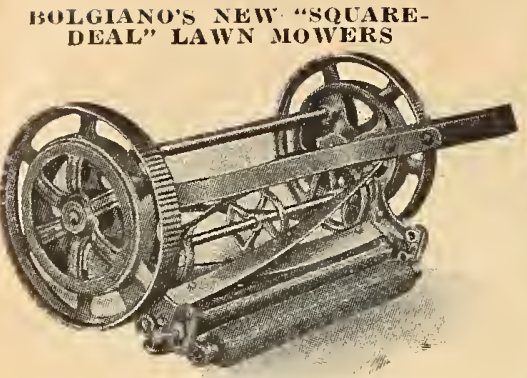

Made of the very best material. Four spiral drawcut wiper blades. Ten-incl skeleton Traction wheels. Automati cally sharpened, lipped edge cuttine inife Coureusatiug Cutter Bar Ad justmen.. Self-aljusting ball bearings. 14 -inch .................. $16-1$ rich $\ldots \ldots \ldots \ldots \ldots \ldots \ldots \ldots \ldots, 10 . j 0$ 18-inch ................ 10.50

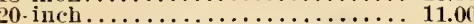

\section{GRASS CATCHERS}

No. 1. Metal Bottom Catchers. 16 inches deep, nuade of heary duck heavy galranized wire frame; adjustable steel hooks, will fit any mower. equipped with perfection havdle Adequipped with perfection hande. Adwide, $\$ 1.25$

No. 2. Metal Bottom Catcher. Same as No. 1, but for mowers, 16 to 20 inches widle, $\$ 1.50$.

\section{GRASS}

SHEARS

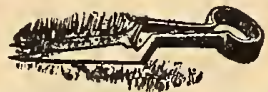

No. 1. Bolgiano's Special......... 45c No. 2 Polished..............70 No. 3. High Polished Steel....... $95 \mathrm{c}$ Iailing weight, 1 lb.

\section{SICKLES}

Fillage Blacksmith, No.33.75c Village Blacksmith, No. $3.60 \mathrm{c}$ Blue Ribbon ........... Gypsy .......... 3 wailiug
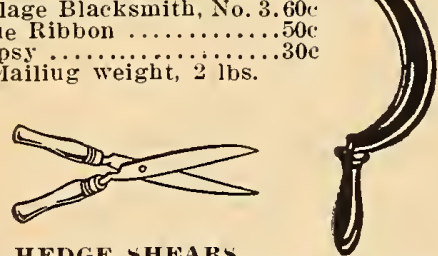

6-inch $\ldots \ldots \ldots \$ 1.10 \quad 9-i n c h \ldots \ldots \$ 1.75$ 8 -inch...... $1.50 \quad 10$-inch $\ldots \ldots \ldots 2.25$ With notch, $25 \mathrm{c}$ extra.

LAWN AND GARDEN RAKES

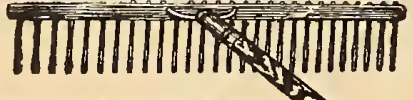

The ole Olsen Lawn Rake The teeth are so constructed that when driven into the head they will never shrink from place and cannot fall out. Prie

6.5c. Mailing weight, $4 \mathrm{lbs}$

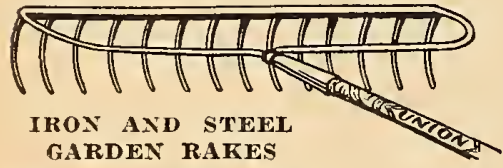

Malleable Rakes. M. S. 12........40

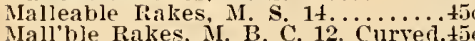
Iallble liakes, M. B. C. 14. Curved.50 Steel Bow Rakes, bent tooth, F.B.1t.85

LAWN QCEEN RAKE

Made of heavy, timned, steel wire These are excellent for lawn or wall work. The rake is reversible and will answer sereral purposes. W 2t-tooth answer several purposes. W. 2t-tooth one side, 12 to the other
60 c. Mailing weight, 5 lbs.
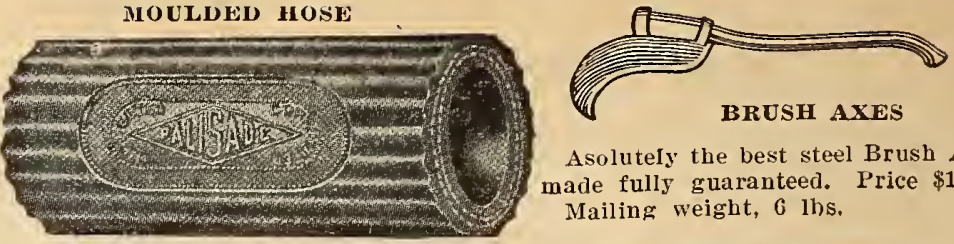

Asolutely the best steel Brush Axe made fully guaranteed. Price $\$ 1.50$. Mailing weight, 6 lhs.
Heary high grades in continuous lengths, rely highest grades of hose made, as high as auy we come in competition with, 3/4-inch, cut anv length desirer, add 25e for coupling.

Per Running Foot

Palisade $\ldots \ldots \ldots \ldots \ldots \ldots \ldots \ldots \ldots . \ldots 18 c$ Thip Cord, $3 / x-i n c h . . . \ldots \ldots \ldots \ldots .22 \mathrm{c}$ Thip Cord, $3 / 4$-inch, corrugated... 23c Electric, $3 / 4$-inch, double fabric.... 25c

Jubilee .................. 22c

High Pressure Hose for Spraying Purposes

Prices on application.

HOSE SUNURIES

Hose Menders, swre grip.....Each.. 15c Hose Couplings ......... ". . $25 c$ Hose Couplings, Snap..... “. . $25 \mathrm{c}$ Hose Bands ................... $5 \mathrm{fc}$

Mailing meight, $1 \mathrm{lh}$. HOSE NOZZIES

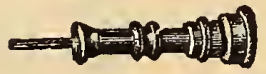

Ilain. 6 inch...50c Mystic Spray..85e

THE FOUN'TAIN SHOUTER

Hose Nozzle with the Mist-Like spray. Price 40c.

THE HALF CIRCLE FOUNTAIN

It sprinkles a semi-circle instead of a full circle Price 65c Shipping weight, 4 lbs. per dozen.

THE ORIGINAL FOUNTAIN

Known the country orer. Price 85c. Shipping weight, 10 lbs. per dozen. The Elgin Lawn Sprinkler.......65 With shield $\ldots \ldots \ldots \ldots \ldots \ldots \ldots \ldots$ 7 $\overline{0} \mathrm{c}$

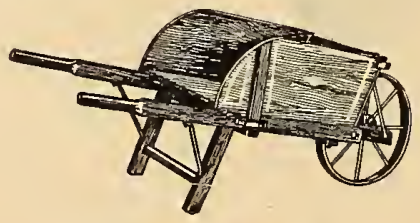

GARDEN BARROWS

These barrows are light. strong and durable, painted and varnished. Inside

Wheel Measurement Price $17 \quad 11 \times 20 \times 25 \quad \$ 6.00$ $\begin{array}{lll}19 & 12 \times 22 \times 25 & 6.75 \\ 21 & 14 \times 2+\times 28 & 8.00\end{array}$ $\begin{array}{lll}21 & 14 \times 2+\times 28 & 8.00 \\ 21 & 21 \times 2+\times 30 & 9.00\end{array}$

GALYANIZED

IRON WATER PO'TS

$+\mathrm{qts} . \$ .9010 \mathrm{qts} . \$ 1.50$ 6 qts. 1.1012 qts. 1.7 sqts. 1.2516 qts. 200

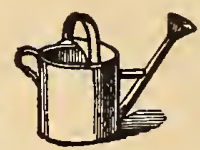

NEBELASTIC GLAZING CEMENT A lerfect Compound for Glazing, Reglazing and Repair Work on Greenhouses and Sash

Prices as follows: 55 and 35 gallon steel drums, $\$ 1.50$ per gallon; 5 gallon cans, $\$ 1.60$ per gallon; 1 gallon cans, \$1.6.5. One Glazing Gun gratis with each 5.5 or 35 gallon divun.

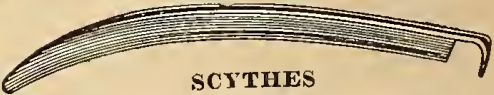

Waldron scy thes, 32,34 and 36 in. $\$ 1.50$ Ames, 36 in . . . 1.00

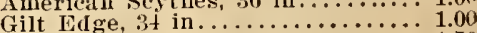
D. E. T. Busl, 20 in.......... 1.50 Handles Extra, with Loop Bolts.. 1.2. Handles, with Rings........... 1.50 Mailiug weight, 5 lbs.

$$
\text { SCYTHE STONES }
$$

Berea Good, No 1............. 15 Berea Good, No. 2 ............. 10 Carbortundum, No. $191 \ldots \ldots \ldots \ldots \ldots$. . . . . Mlailing weight, 2 lbs.

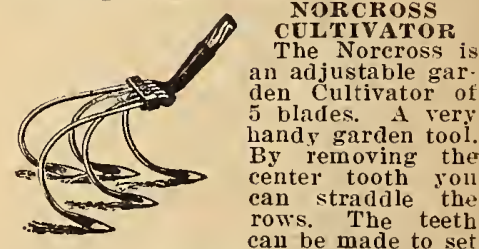
close or wide a part. Can be detache from handle and attached to any whe hoe. Price, 5 blades, $\$ 1.25$. 3 blades soc. Mailing weight, 8 lbs.

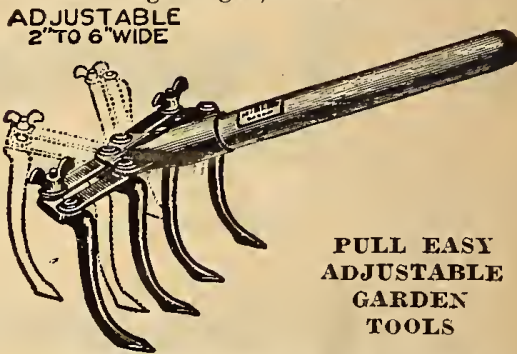

Everyone who has worked in a garIen will see at a gIance the advantage of the "Pull-Easy" over any other kind of a garden tool. W'hen the arms are spread out to full width of 18 inclie the cultivator is like a rake.

For narrower rows the outer ends of arms can be closed to any width down to 7 inches

Hand Cultivator, 9 tooth, long

handle $\ldots \ldots \ldots \ldots \ldots \ldots \ldots \ldots \ldots 1.50$ Pull-Eas , Jr., short handle, 4 tooth. Pull-Easy,Jr., longhandle, 4 tooth 80 . Pull-Easy Weeder ............. . .

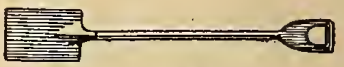

\section{SPADES}

D Handle, No. 2, plain.........\$1.2 D Handle, No. 2, polished.......... 1.50 D Handle Post or Ditching Spade.

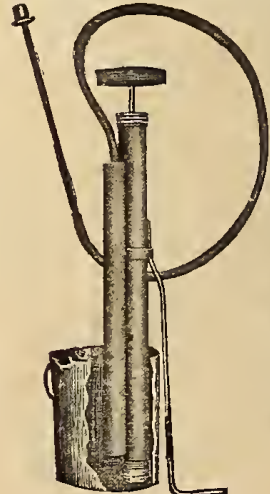
o.... 1. 11 ailing weight 8 lbs. No. 20 WHITE VASH SPRAYER AND FORCE PTIP No. 28. Whitewash $\mathrm{S} \mathrm{p} \mathrm{r} \mathrm{a} \mathrm{s}$ e and Force Pum: is designed for use in pail or bucket, and $\pi i !]$ fit any size.

Price. \$3.25. 
We can

supply the

Leading

Varieties

of

Bolgiano's

Vital-Strain

Thorough-

bred

Poultry

that are

most

suitable for

Commercial

Purposes

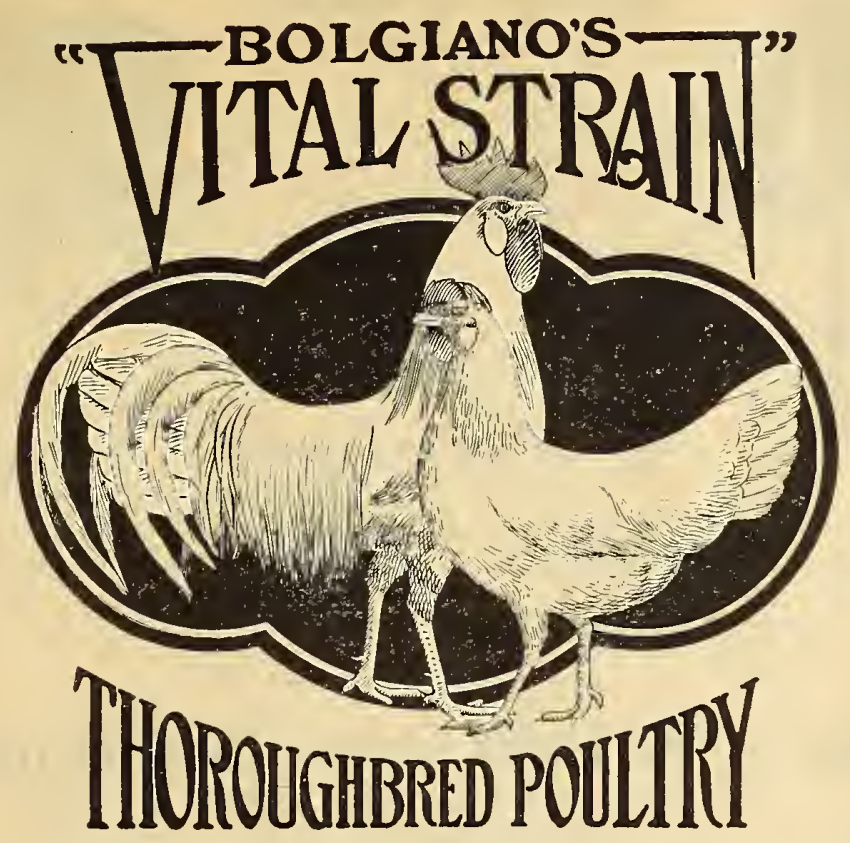

38

Write us

for prices

on

Bolgiano's

Vital-Strain

Thoroughbred

Poultry

naming the breeds

you desire.

We can

supply

Single Birds

or Pens

\section{Bolgiano's Poultry Department}

Is Equipped to Serve You

Ir. Frederick H. Thayer, personally well known to thousands of our customers, has so successfully conducted our Poultry Department and has, for a number of years, hejped so many to profitable success with their poultry, that it seems an opportune time to tell you bow and why Mr. Thayer has been successful.

Ir. Thayer has made tbe study of poultry and their needs his life work. He owned and mausged for twenty years one of the leading poultry farms in New England, located on Cape Cod, Massachusetts, and later he become associated with the largest poulíry supply houses in New England. Ife attended Cornell University, at Itbaca, New York, where ho was successful in adding scientific know.edge to his twenty-five years of practical experiences. In this way he has most thorough:y experienced himself, from a scientific, practical and commercial standpoint, having always in mind a desire to so equip himself that ho would be thoroughly competent to help others to make a success of the poultry industry.

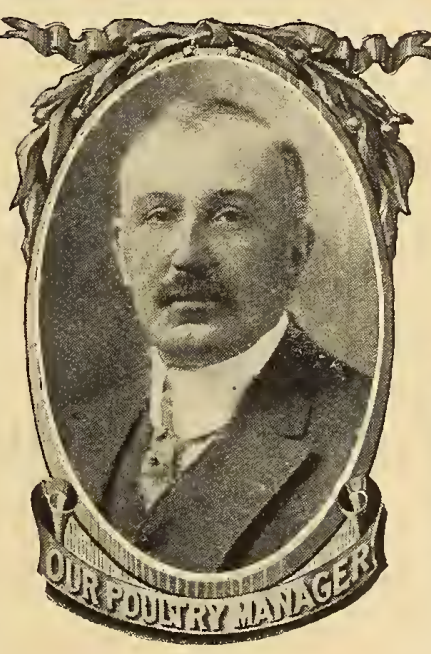

It is Mr. Thayer's greatest pleasure to answer all of the many perplexing questions pertaining to the poultry industry. It is always a pleasure to him to meet our friends and customers, personaly, but as this is not possible, he cheerfully invite detail information as is possible regardins your poultry troubles, and it will be bis pleasure to write to you promptly.

Ir. Thaser personally oversees the mating, breediug and reneral management of the parent stock or breeders, from which we supply thousands of exgs for batching and baby chickens. Our breeders are all selected for their reproducing qua'ities, adhering as plosely to the standard requirements as is possible, without losing sight of the commercial or dollar-earning qualities, We are using the "Hogan Srstem" in selecting our breeders as closely as is possible without oiverstepping the bounds, thereby aroiding the danger of weakening the constitutional, vigor of the breeders.

In the selection of the breeders, Mr. Thayer is particular to discard any female from the breeding yards that does not produce an equ weighing two ounces or from twenty-four to twenty-six ounces to the dozen, This weight egis brings the highest prices in our eity markets.

Place Your Order With Us Now for Bolgiano's “Vital-Hatch ” Baby Chicks for 1920 Delivery. Chicks with Vitality.

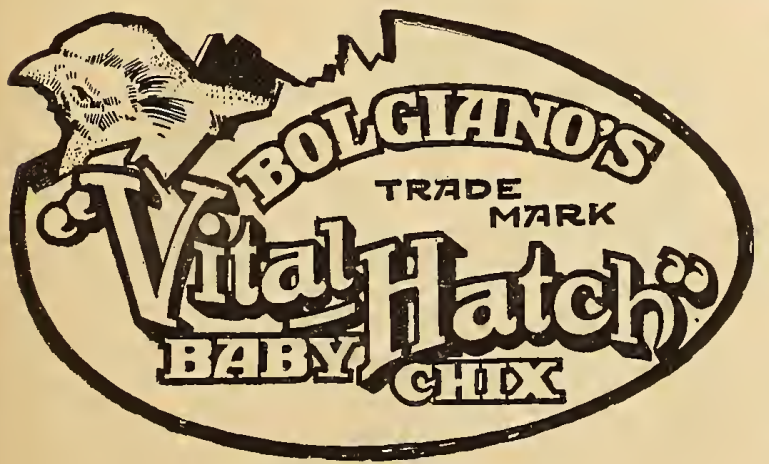

We ship Baby Chicks from Canada to Florida---Maine to Kansas---All Charges Prepaid---Safe Arrival Guaranteed

We can supply the Leading Varieiles which are the most suitable for commercial purposes.

Our first consideration is for Constitutional Vigor and rood ego production, within the breed

The demand for "Vital Hatch" Baby Chicks has in reased beyond our fondest expectations. We have firt out more than 'Two Hundred Thousand Chicks this season therefore sou can readily see that it will be to your hest advantage to place your order with us early for your next season's requirements.

Weather conditions nermitting. we will commence hatching in January, 1920.

We are shipping Thousands of "Tital Hatch" Baby Chicks into the Sonl bern States ind we wirl have phoni. sands of Chicks hatelued for the Southern trade during January, February and Mitrh. as well as later in the season.

We Supply Eggs for Hatching from Thoroughbred Stock. 


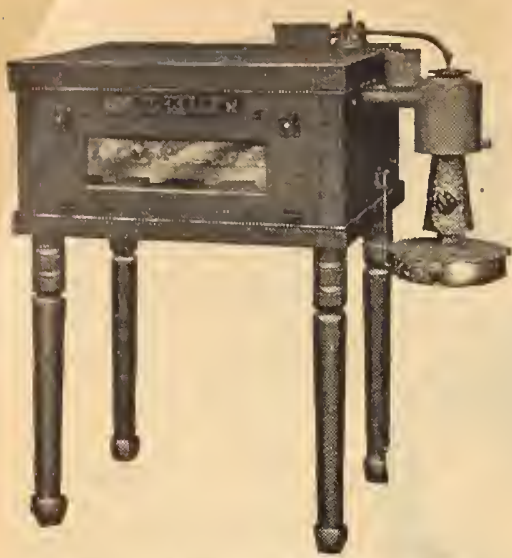

No. 15 (Style II), 60 Egrs, $\$ 14.50$

\section{Buckeye Incubators}

\section{The Perfect Hatchers}

\section{FIREPROUNED}

Inspected and approved bi the Nat-

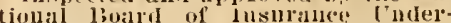
writers. Every machine is bilit in accordance with the strict perres and regulations of the Luderviters Laboralories and beals flus label of approvit. Hence, they alpe all ac-ceptable risk with every insurance conlually in the wollel.

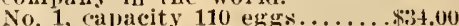

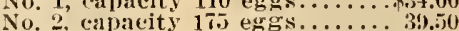

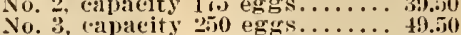
No. 4, capacity 350 eggs....... 58.50 No. 5 , capacity 600 eggs....... 95.00

New 0il-Burning Brooders

These Brooders were designed to meet the demand for a portable Brooder to sell at a lower price than the "Security."

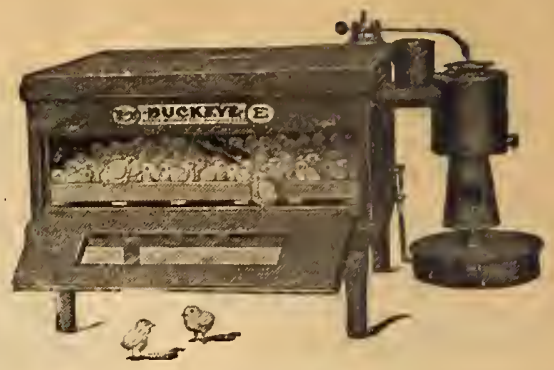

STYLE E

Buckeye 60-FgE Ineubator

VOT A TOY-NOT AN EXPERIMENT -BCT A REAL MACHINE

111 Ready to Use, $\$ 15.00$

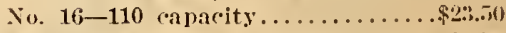
No. $17-200$ capacity . . . . . . . 32.50

These new Brooders will be known as "Buckeye Portab'e Brooders," and unmbermas follows.

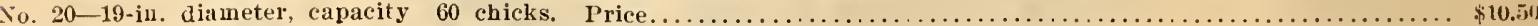

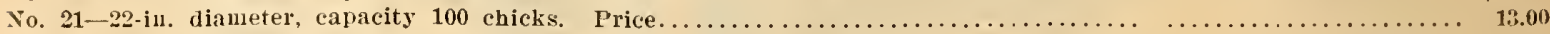

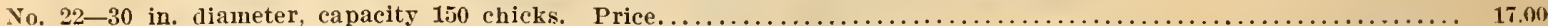

This is a wouderful line of brooders and they will fill a long-felt want.

\section{Our Little Baby Grand Incubators}

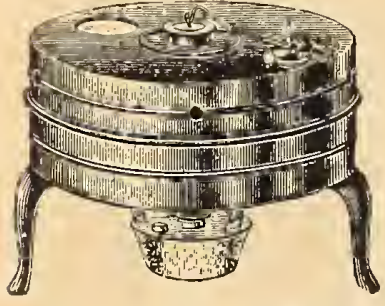

Cap. Kind. Size. 80 Eggs Hot Air $12 \times 23 \times 29$

Shipped by Express or Parcel Post. Price, $\$ 6.00$, F. O. B. Baltimore.

Unique and superior in its construrction. Beautiful in its appearance. Excellent in its hatching qualities, and most reliable, easiest operated small incuhator ever offered. It has a glass window in top, so that thermostat can he seeu without opening, and chickens can he seen hatching without opening the machine. Just the thing for the small fancier, easy to operate, self-regulating. Owi guarantee goes with ilis littir Incubator.

\section{OUR LITTUE MARVEL, INCUBATOR}

$50 \mathrm{Egg}$ Size by Express or Parcel Post, \$6.00. F. O. B. Baltimore.

The construction and operation of this machine is designed to closely follow the natural process. The hatching chamher is a real nest with a fclt-lined bottom.

\section{OTIER RELIABLE STANDARDS}

Prlce. No. Cap. Kind. Size. Weight.

\section{The Reliable Blue-Flame Oil-Heated Colony Hoover}

CAPACITY 50 CHICKS.

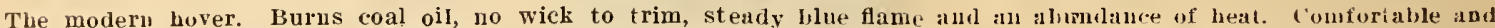
easy to operate. No oil fumes, Economic to operate, no oil smoke or gas. The fow of oll is regulaterl alutomatically. Price, $\$ 7.50$. 39-inch size, $\$ 16.50$. 42-inch size. $\$ 18.50$. 52 -inch size, $\$ 22.00$

\section{Improved Roller Tray Incubators}

No matter how correct the principle upon which an incubator is built, unless high-grade material is used in it couction it will never prove satisfactory and in a short time be practically worihless. For this reason we lial' sparec no expense in making the Roller Tray Incubator of the hest material obtainable.

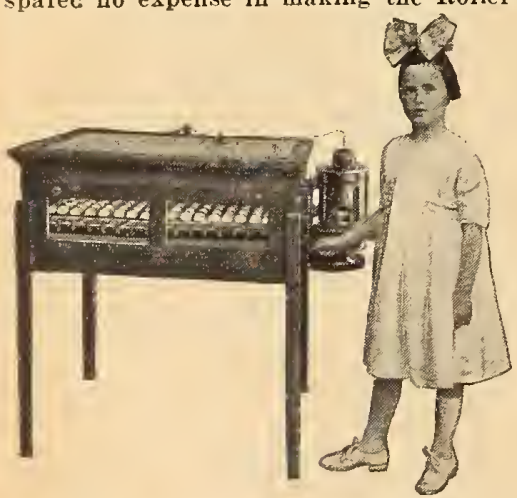

ROLLER TR.AY INCUBATOR

A Turn of Crank Turns Every Egg No. 1-Incubator, Capacity 60 Eggs Can he Heated by Oil or Gas Flame Built of wood. copper heater. complete ready for use. Equipped with lamp meeting Urderwiters' requirements, as per cut above....................... shippine woight shout iio lbs.

The Improved Roller Tray lncubators are finished in natural color, each machine being given a coat of shellac and then coated with varnish specially adapted to withstand heat and moisiure. The glass door is of dowhle thick ness, with air space between.

Prices Complete F. O. B. Baltimore.

No. 2-Incubator, Capacity 100 Eggs.

Can be Heated by Oil or Gas Flame.

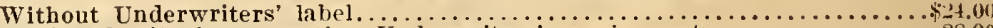
Equipped with lamp meeting Underwriters requirements............... 28.00 Shipping weight ahout $125 \mathrm{lhs}$.

\section{No. 3-Ineubator, Capacity 150 Eggs.} Can lise lleated by oil.

Equipped with lamp meeting Underwriters' requirements. $\ldots \ldots \ldots \ldots \ldots \ldots \$ 34.00$

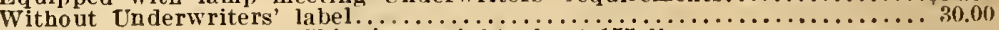
Shipping weight about $155 \mathrm{lhs}$.

\section{THE STANDARD COLONX BROODER}

Broods 1000 Chicks. Price $\$ 24.75$.

Coal burning. Self-Regulating. Chicks Always Visibie.

THE MOST REMARKABLE COAL-BCRNING BROODER EVEK INWENLI) It is Self-Fecding. Self-Regulating, Simple, Safe, Everlasting, and the Guraranteed operating Cost is LESS THAN SIX CENTS A DAY.

The Standard Coal-Burning Brooder is now manufactured in two sizes and numbered as follows:

No. 18 Standard Brooder, 52-inch Hover and large store. Price........\$19.75 No. 19 Standard Brooder. 42 -inch Hover and stove. Price............. 4.75

The Standard Colony Brooder is GUARANTEED to do everything that : :uy hrooder on the market will do-and do it hetter-no matter wliat the of her brooder costs. 


\section{Bolgiano's "Square-Deal” Portable Poultry Houses}

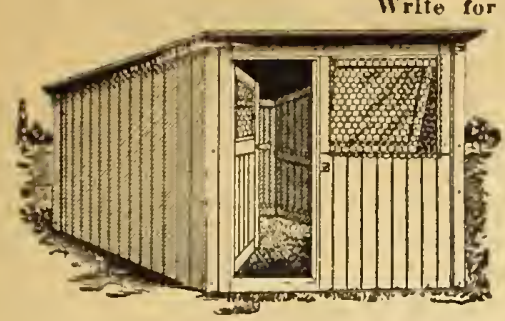

Isolgiuno's "siguare-Deal" Combination Open and Clasal Front llouse.

This louse is 6 foet wide and 8 feet deep, $61 / 2$ leet high in front. $4 \frac{1}{2}$ feet back. The frout is boilded up 3 feet, thereby avolaling any firect wind or storm striking

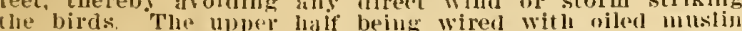
screans, wives the olren-front toiture with plen, of fresh

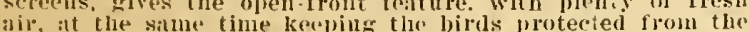

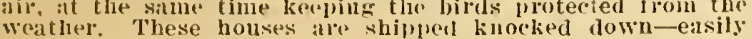
put cogether in halt an linur. Weight, rritel for shipment. jist poinuls

Price, \$3t.00, F, U. 1. Baltimore.

\section{Poultry Supplies}

CUT PRICES

POLLTRY WIRE:

Galvanized After Weaving 2 in. Hesh. Roll of 150 Feet. Spccial Prices in Quantity.

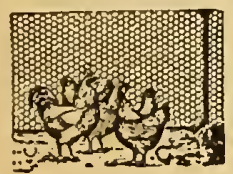

12 in....\$1.40 48 in... $\$ 5.60$ $2+$ in... 2.80 60 in ... 7.00 36 ill... 4.20 72 in ... 8.40

PIGEON WIRE

Galvanized After Weaving. I in. Mash. Roll of $\mathbf{1 5 0}$ Feet. 12 in....\$2.80 36 in.... \$ 8.40 $24 \mathrm{in...5} 5.00$ \$8 in... 11.20 lin in. ............ 14.00

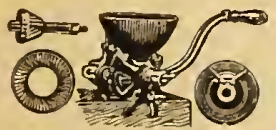

KHIV ('IIFA IMIROVHI) IILI.

l'rice. \$4.75 Each

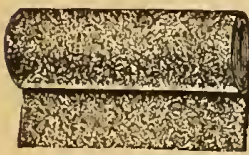

“(ERTAINTEED"

"SQCARE DEAL"

ASPHALT ROOFING

Fully Guaranteed 5, 10 anu 15 years. $10 \mathrm{~s}$ square feet. Vials ind c'ement Includerl. (111. - ly............ \$1.75, Two-Iig...........

hin rep-1.

\section{DEAL" WATER GLAST}

Will kiepl liggs perfectly sweet and retain their good (a) ing qualities for one yenr. (1) part Water Glass to 11 liats Water.

size, 1 qmart, $30 \mathrm{c}$ each.

Malling weight, $t$ lls

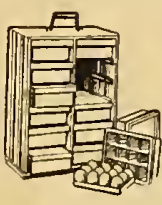

\section{PARCEL I'OS'T EGG} BOXES

Mailing Weight Each. Per Doz $9 \mathrm{c}$ Each, 1 Doz., $1 \mathrm{lb} . . \$ .90$ 12e Each, 2 Doz., $1 \mathrm{lb} . .1 .2$ 14e Each, 3 Doz., 2 lbs. 1.40 17e Each, 4 Doz., 2 lbs. 1.70 20c Fach, 5 Doz., 3 lbs. 2.00 $22 \mathrm{e}$ Fach, 6 Doz., 3 lbs. 2.20
$30 \mathrm{c}$ Eacl, 10 Doz., 6 lbs. 3.25

\section{EYRIE EGG IBOX}

Mailing Weight Fach, Doz. $15 \mathrm{lgg}$ Size, 1 lb..20c $\$ 1.90$ 3n Fgg Size. 2 lbs..25c 2.85

FARMERS
MOLEIRN EG

CRATE

1) $10 \%$ Size 100 4 1)0\%. Size, \$1.00 6) Doz. Size, 1.25
\& Doz. Size. 1.50 Doz. Size, 1.50
Doz. Size, 2.00 Not Mailable.

\section{LOOK! LOOK! LOOK!}

"SQTARE-DEAL" FGG: BOXES

For handling Retail Fgg 'l'rade.

Doz. Size I'rice Mailing Wt

$\begin{array}{rrrr}\text { Toz. Size } & \text { Price } & \text { Mailing } \\ 12 & \$ .25 & 2 & \mathrm{lbs} . \\ 100 & 1.50 & 10 & \mathrm{lbs} . \\ 0.50 & 3.00 & 28 \mathrm{lbs} . \\ 1000 & 9.00 & & \end{array}$

By Fxpress, not paid.

CHICK IHOXES-TOO

IARGE FOR MAILING

For Shipping Day - Otd Chicks. Dacli. Do\% 2.) Click, 12x 6.x...18e \$1.80 50 (hick, $12 \times 15 \times 5$.

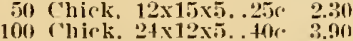

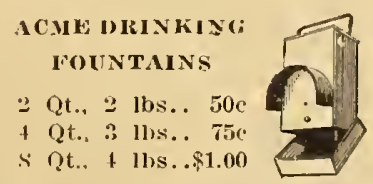

s $\mathrm{Qt.} .+1 \mathrm{bs} . . \$ 1.00$

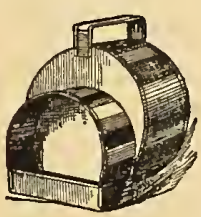

TI E "BOSTON" HOCNTAIN 2 Qts....45. 4 Qts....55e 8 Qts....8. 8 :

ROLND BOTTOMI GRIT ANU SHELI, BOX

Price, 90c

Hailing Weigh $3 \mathrm{lbs}$.

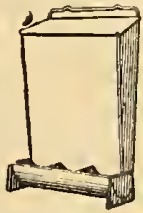

1-2-3 POULTRY FEEDER

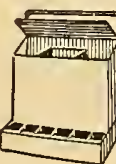
Whell used fol ihree kinds, say, seraps, shell, sand. grit, put separator in middle and you

No. 1, small size, 85e. No. 2 , large size, \$1.25. Misiling wejghts, No. 1. :; lbs.; No. $\because, 51 \mathrm{bs}$.

GRIT INI SIIELI lt is provided with lid and cover. which protects the contents and may be suspended to
the wall of noul. try hollse by the haindle. 3 Compartments ...... 40

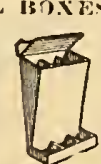
10 Ouarts Maling Weights. 8 i 9 ibs.

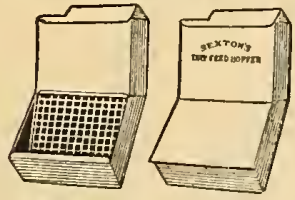

SFXTON DRY FOOI) II (D) I'EIr

Wach. Mailiug we.

No. 5. 1 131r.\$2.50 4 16s.

Large Sige.. 1.75 7 lbs.

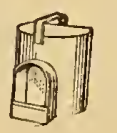

STAR WALI. FOUNTS $\because \mathrm{Qt}, 2 \mathrm{lbs}$. $50 \mathrm{c}$ + Qt., 3 1bs.. 65. $\checkmark$,t., 3 lbs. .\$1.00
ING HOUNTIINA $1 \mathrm{rt} . \mathrm{llb}$ l......... $\Rightarrow$ Qt. 2 ibs...... 2... G llis.....
IIYGEIA OR ANTISHITIC NEST EGG

They contai infectant whicl is guarauteel to drive out al Each 6c. Doz vermit. postpair.

\section{OPAL OR CIIINA NEST} EGGS

Whi.e, flint, will last ifetime, 5c each; 12 for $40 \mathrm{c}$

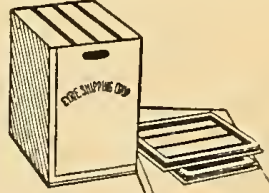

EYIIE SIIIPING COOPN Too Large for Mailing. Letter Fach Doz

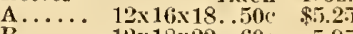
B..... $12 \times 1.8 \times 22 \ldots 600 \quad 597$ $\mathrm{D} \ldots \ldots .20 \times 22 \times 22.80 \mathrm{c} \quad 8.75$ F..... $20 \times 24 \times 2 . .90 \mathrm{a}$ 9.5

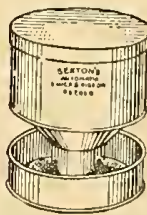

SEXTON AUTOMATI CIICK AND I'IGEO FEEDER Each. Maling Wt

Peeders. Stic 3 ins
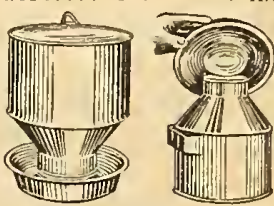

iEXTOY FOEVTIIY Each. Mlailine U

F.ITORITE DIRY H.ISI IIOI'I'EF

13 Qt. size.....\$1..30 it $1^{1} \Leftrightarrow$ Pu, size..... 


\section{Bolgiano's "Square-Deal" Poultry and Pigeon Foods}

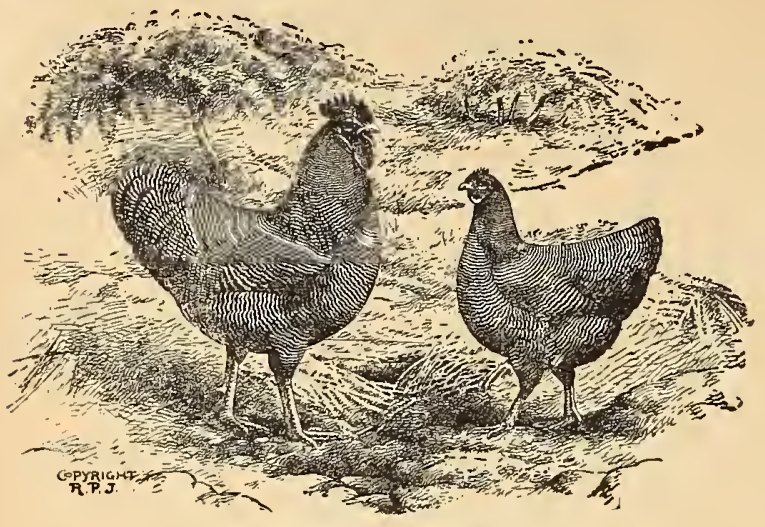

Barred Plymouth Focks

"SQUARE-DEAL" CHICK STARTER

A Primary Food for lbaby Chicks Cp to Three Weeks Old This is a primary food tor Baby Chicks; contains only the best selected, recleaned, sound, sweet, cracked grains and seeds in proper proportions essential to quick and healthy growth
duce exercise

\section{"SQUARE-DEAL" CHICK FOOU}

This is a carefully selected ame complete food for small chicks. It is a high-grade mixture of recleaned, sound, weet. cracked grails and seeds, and is an intermediat food for growing chirks too small to eat our Square-Dea siratch rood. II ake them work for it; exercise promotes health and aids digestion.

\section{"SQUARE-DEAL" GROWLNG MASH}

Our growing Mash is a mixtwre of whole, choice, sweet trains with a little meat added, evenly balanced and ground together in such a manner as to wromote the quickest pos-
silile growth. Feed lly alld rou will be surprised at the results. Poultry of all kinl when fed dry eat very slowly. mixily it thoroughly with the saliva, and then with the acids of the stomach, comsequently there is a slow digesting wrocess going on all day. They never gorge themlash with the Growing llash and wateh results.

Bolgiano's "Squnre-Deal" Beef Scraps or Meat Meal. For success with poultry it is absolutely necessary to give tor success with poiltry food. For this purpose "Squarethem., plenty of animal food. For this purpose "squar

eal" Beef Scrajs are the best food that can be used. and is very nutritious and appetizing. When fed separately steam weli before using.

Bolgiano's "Square-Denl" Cruslied oyster shells. The liest poirtry" authorities lecominend the "Grit-Box" system. Our flesh ground shell supplies Carbonate of Lime to increase the ploduction of eggs. I'oultry, pigeon and chick sizes.

\section{POULTRY AND PIGEON SUPPLIES}

We can supply the following selected ingredients in large or small quantities at the lowest possible pricea, quality onsidered :

Feeding Rice

Wlite Kaffir corn

Red Kaffir Corn

Mi'o Maize

Extra Large sunflower

llemy seed

Tobacco stem

Tobaceo stem

Tobaceo Dilst

Corn Cliop

Middlings

Fisll serays

Flax Seed Meal

Wheat Bran

cluten Meal

Folden Grain Horse and Mule Feeds, 60 per cent grain, 40 per cent alfalfa meal and molasses.

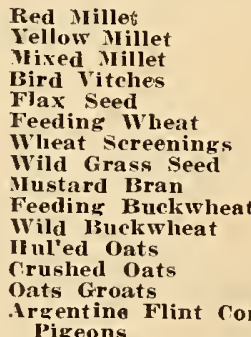

Jellow forn

Cracked forn

Fine Cracked Corn

simall Pigeon Corn

Cracked Wheat, Sifted

Fancy Peanuts for Pigeons

Ground oats

Rolled oats

Bird Rape

Feeding Barley

Steel rut Oats

Canada Peas, Fancy

Canada Field Peas, Prime

Soja Beans for Feed

Green Wrinkled Peas

Feeding Oats

\section{"SQUARE-DEAL" GUARANTEE}

Bolgiano's "Square-Deal" Poultry Foods are abye the best can be produced. Our long taught us what ingredients althy vigorous fowls and increase egg production. grains and seeds enter into the man-

"SQUARE-DEAL" POULTRY FUOD gliest Grade-Contains sunflower Seed

Puritan Horse and Mule Feeds, 50 per cent grain, 50 per cent alfalfa meal and molasses.

\section{Poultry and Pigeon Bands}

ALI POSTPAID REGARDLESS OF DISTANCE

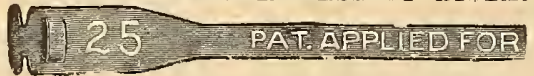

C'llampion Adjustab?e. 12 for 20c. 25 for 35c. 50 for ceader Adjustab'e, 12 for 15c. 25 for 25 c. 50 for $40 \mathrm{c}$ 100 for 650

Climax. Made of spring brass and so made that ta acts as clasp. 12 for $25 \% .25$ for toc 50 for 60 c. 100 for $\$ 1.00$
Smith Sealed Stock Numbered. 12 for $25 \mathrm{c}$. 25 for $50 \mathrm{c}$ 60 for $\$ 1.00$. 100 for $\$ 1.50$

Sealers. Plain, 50c. Lettered, 75c. Nickeled, 25e extris. Spir-ol Leg Bands. Celluloid Band. made in five colors. 12 fol $18 \mathrm{c}$. 25 for $30 \mathrm{c}$. 50 for $55 \mathrm{c}, 100$ for $\$ 1.00$.

Seamless Bands, 12 for 25c. 25 for $40 \mathrm{c}$. 50 for $65 \mathrm{c}$ for $\$ 1.15$

Double Clinel Pigeon Bands. 12 for $20 \mathrm{c}$. 25 for $35 \mathrm{c}$. 50 for $50 \mathrm{c}$. 100 for $85 \mathrm{c}$.

Follst Health Grit for
Pigeons
Cliarcoal, prepared, all sizes
White Rice Pop Corn
Cracked Corn and Crusled
Oats
Cottonsed Meal
Dried Irewers" Grains
Distil'ers' Grains
Mica Spar Grit
Hen-Eta Grit,
"Square-Deal" Heilt
Pigeon Grit
Digester Tankage for Hogs
Perfection Dog Feed




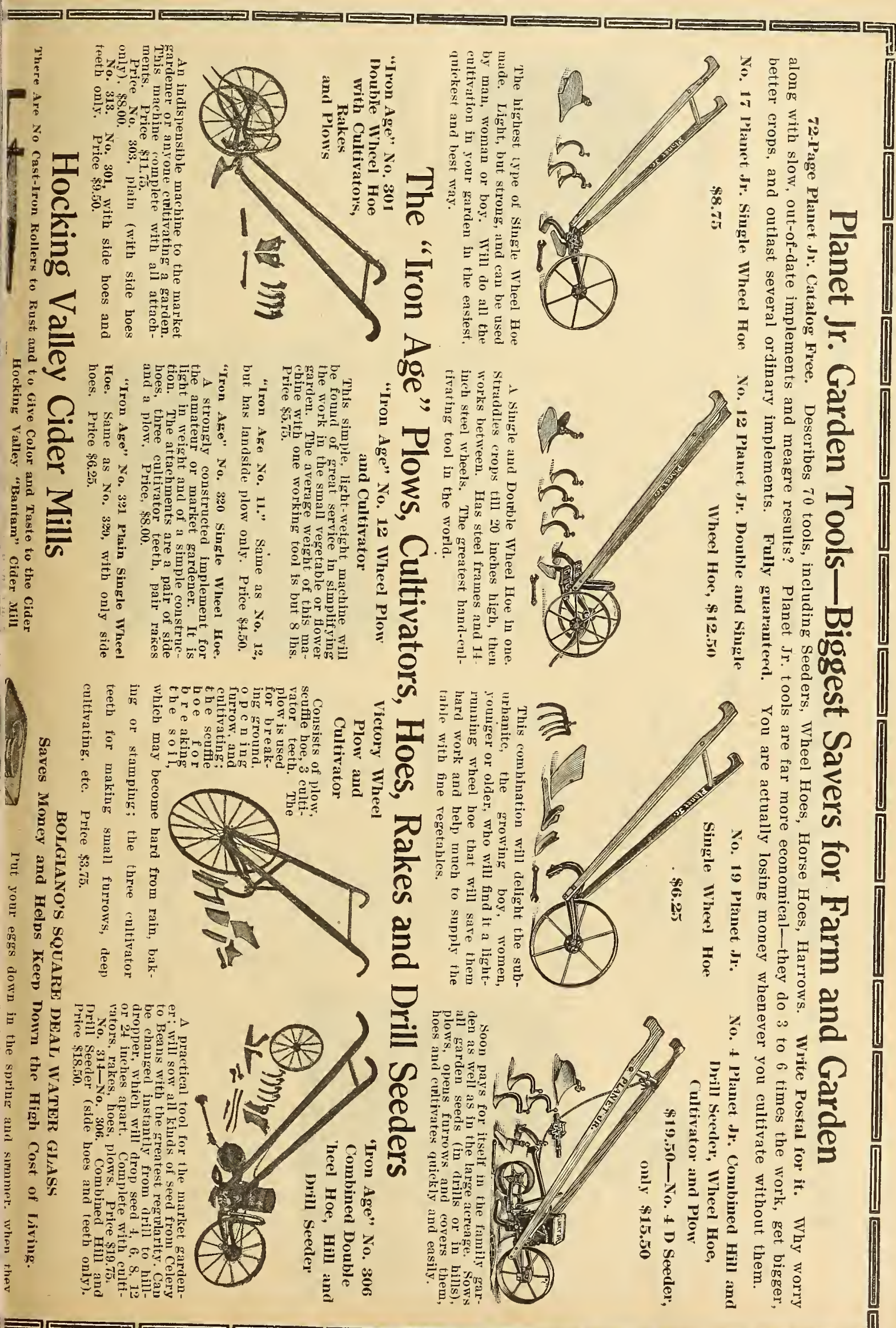




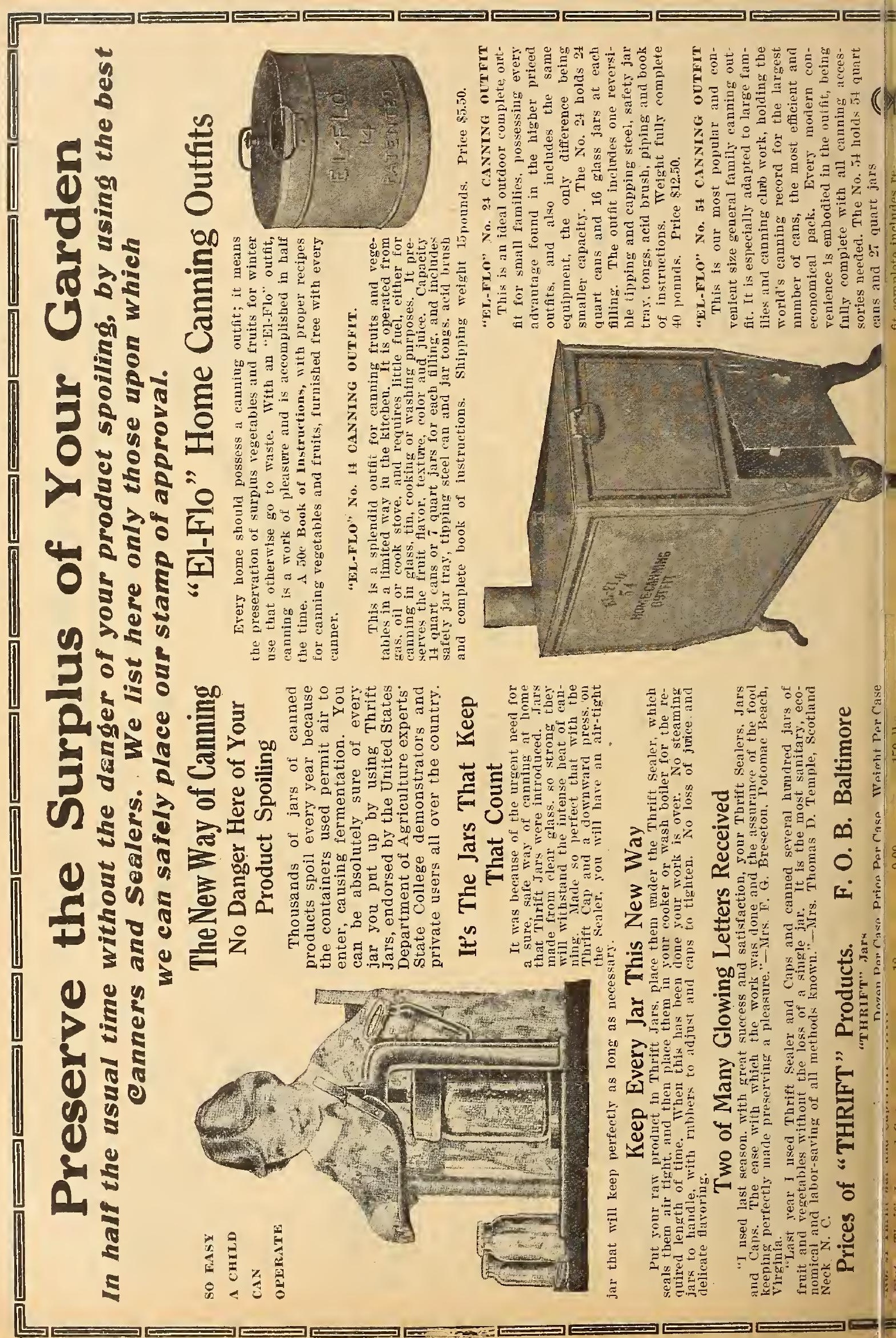




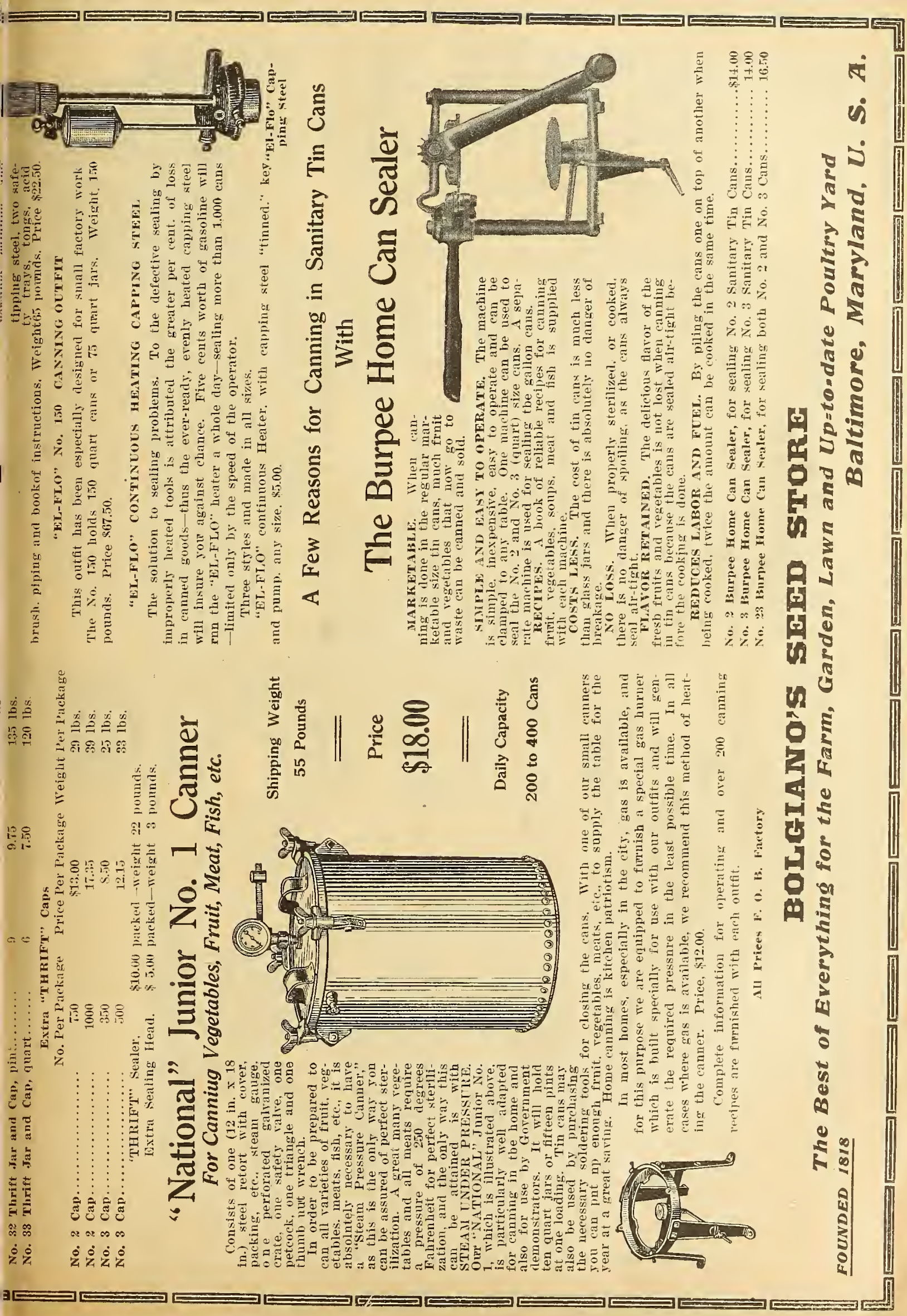




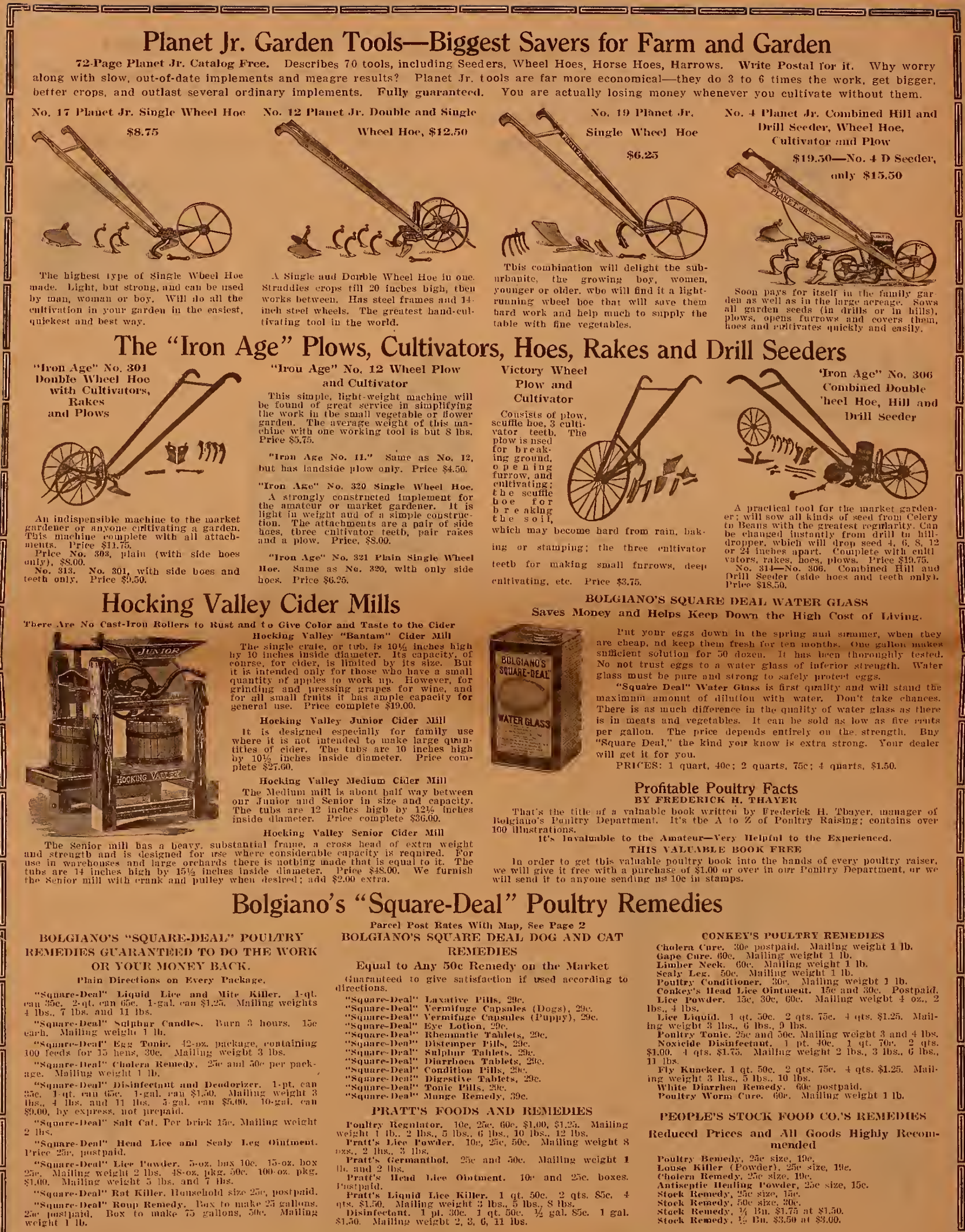




\section{Preserve the Surplus of Your Garden}

In half the usual time without the dinger of your product spoiling, by using the best canners and Seelers. We list here only those upon which we can safely place our stamp of approval.

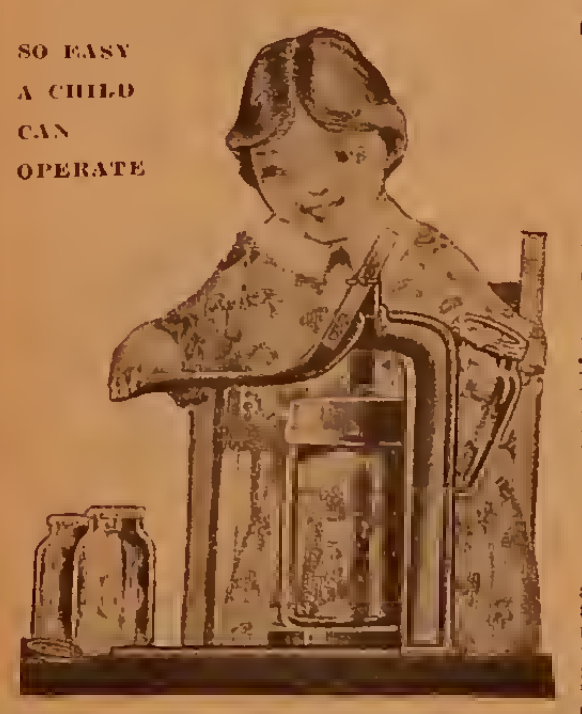
The New Way of Canning

No Danger Here of Your Product Spoiling

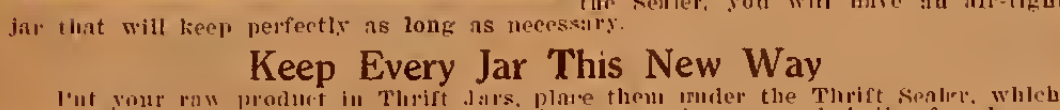

It's The Jars That Keep That Count

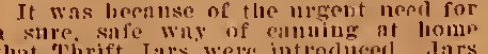

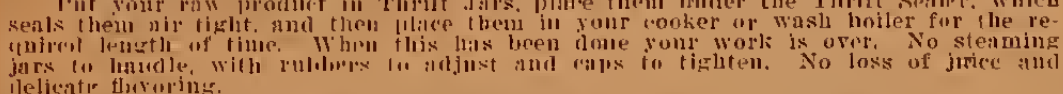

Two of Many Glowing Letters Received

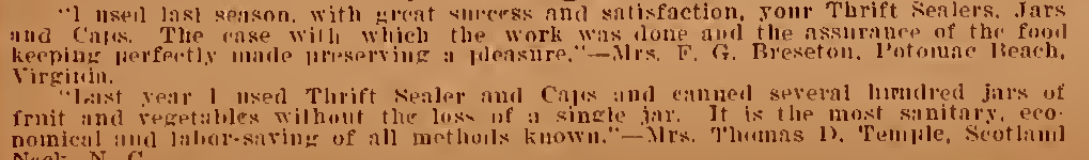

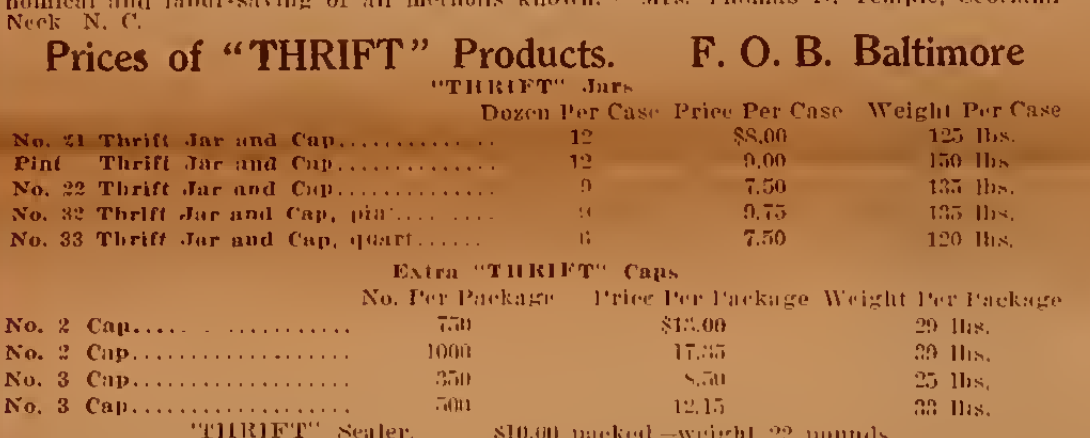

\section{"National" Junior No. 1 Canner For Canniug Vegetables, Fruit, Meat, Fish, etc.}

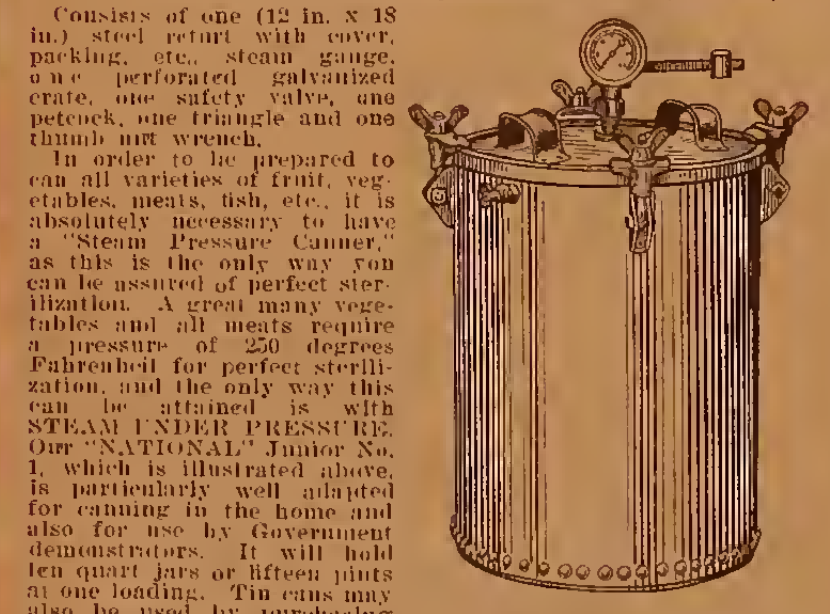

Shipping Weight 55 Pounds

\section{$=$ \\ Price} $\$ 18.00$
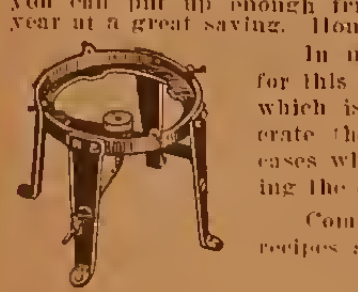

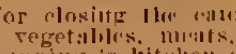

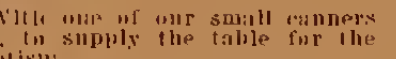

Daily Capacity

200 to 400 Cans 
